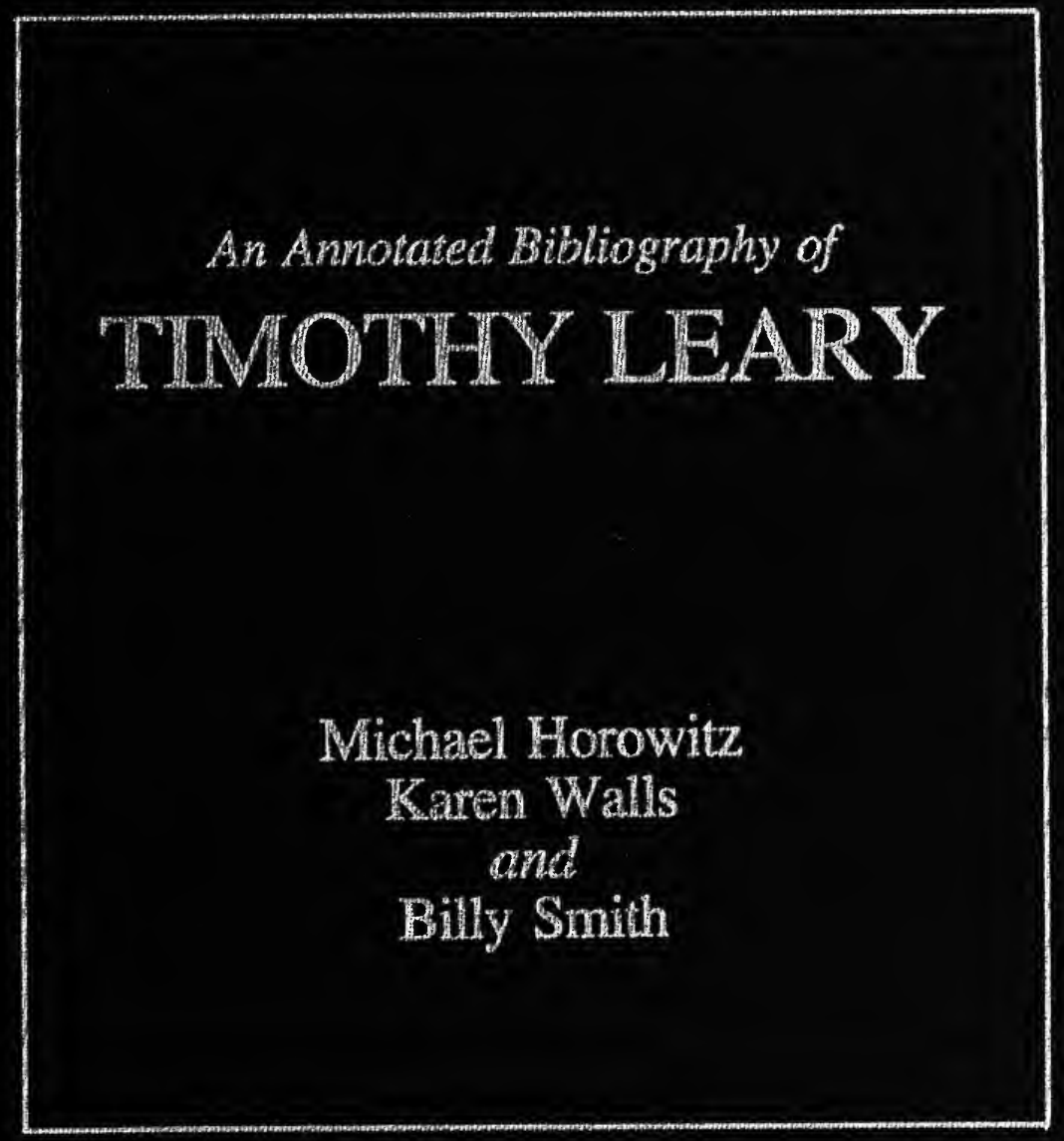


S. F.

Jen' 97 To Rosiman-
On of the gentest presences in this book.

Lort Mubue 
An Annotated Bibliography of

\section{TIMOTHY LEARY}


TIMOTHY LEARY, 1987

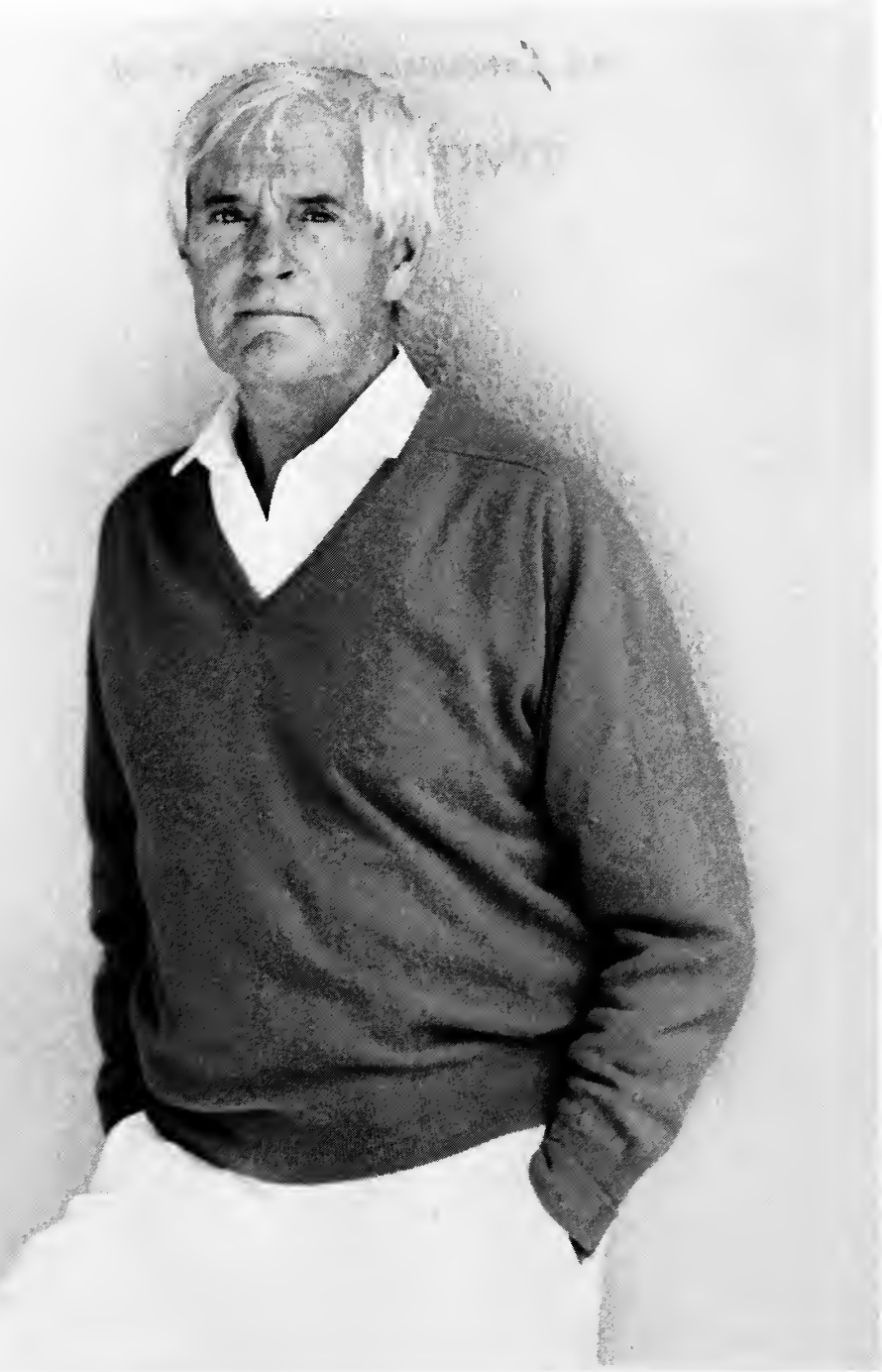

Photo by Frederic Ohringer 


\title{
An Annotated Bibliography of \\ TIMOTHY LEARY
}

\author{
by \\ Michael Horowitz \\ Karen Walls \\ and \\ Billy Smith
}

Foreword by Allen Ginsberg

Preface by Timothy Leary

Introduction by Frank Barron, Ph.D., Sc.D.

Professor of Psychology,

University of California, Santa Cruz

Archon Books

1988 
(C) 1988 by Michael Horowitz, Karen Walls and Billy Smith.

Foreword (C) 1968 by The Village Voice; (C) 1970, 1988 by Allen Ginsberg.

Preface (C) 1988 by Timothy Leary.

Introduction (C) 1988 by Frank Barron.

All rights reserved.

First published in 1988 as an Archon Book,

an imprint of

The Shoe String Press, Inc.,

Hamden, Connecticut 06514

Library of Congress Cataloging-in-Publication Data

Horowitz, Michael, 1938-

An annotated bibliography of Timothy Leary / by Michael Horowitz,

Karen Walls, and Billy Smith; foreword by Allen Ginsberg; preface by Timothy Leary; introduction by Frank Barron.

p. $\quad \mathrm{cm}$.

ISBN 0-208-02064-0 (alk. paper)

1. Leary, Timothy Francis, 1920- -Bibliography. 2. Psychology-Bibliography. 3. Social sciences-Bibliography. 4. United States-Social life and customs-20th century-Bibliography. 5. United States-Social conditions-Bibliography. I. Walls, Karen, 1952-. II. Smith, Billy, 1951- . III. Title.

Z8494.19.H67 1988

[BF109]

016.15-dc19 87-30816

\section{A Fitz Hugh Ludlow Memorial Library Edition.}

The paper used in this publication meets the minimum requirements of American National Standard for Information Sciences -- Permanence of Paper for Printed Library Materials, ANSI Z39.48- 1984. @

Printed in the United States of America 


\section{Contents}

Foreword by Allen Ginsberg 1

Preface by Timothy Leary 5

Introduction by Frank Barron 11

Acknowledgments $\quad 15$

$\begin{array}{ll}\text { Editors' Note } & 17\end{array}$

A. Books, Pamphlets and Computer Software 19

AA. Monographs, Offprints, Mimeographed Reports and
Broadsides

B. Books with Contributions 120

BB. Books with Reprinted Works 171

C. Journals and Magazines with Contributions 180

D. Interviews 201

E. Translations of Books and Articles 208

F. Phonograph Records and Tape Recordings 214

G. Films and Television Shows with Appearances by Timothy Leary 221

H. Works Edited 224

I. Unpublished Writings and Talks 225

J. Books, Articles, Songs and Films about Timothy Leary 227

K. Legal Briefs and Documents Pertaining to Timothy Leary 280

L. Miscellanea, including Posters, Fliers, Slogan Buttons and Bumper Stickers 286

Title Index 
This book is dedicated to two very young women who were born while the work was in progress

$$
\text { Jasmine and Sierra Marin, the Wallsmith sisters }
$$

with the hope that a few of the books described herein are on the standard reading lists of the colleges they attend in the twenty-first century. 


\section{Foreword}

\section{Allen Ginsberg}

By the late ' 40 s of this memory Century the people I knew best and loved most had already broken thru the crust of old Reasons \& were dowsing for some Supreme Reality, "Christmas on Earth" Rimbaud said, "Second Religiousness" according to Spengler's outline of civilization declining through proliferation of non-human therefore boring technology; Blake had called "O Earth O Earth return!" centuries before, echoing the ancient gnostic prophecy that Whitman spelled out for America specifically demanding that the Steam-engine "be confronted and met by at least an equally subtle and tremendous force-infusion for purposes of spiritualization, for the pure conscience, for genuine aesthetics, and for absolute and primal manliness and womanliness- "Ezra Pound's mind jumped to diagnose the dimming of the world's third Eye: "With Usura the line grows thick."

One scholar who transmitted Blake's kabbalah, S. Foster Damon, could remember his sudden vision of tiny flowers carpeting Harvard Yard violet before World War One, an image that lingered over 60 years in mind since his fellow student Virgil Thomson gave him the cactus Peyote to eat. Damon concluded that rare beings like Blake are born with physiologic gift of such vision, continuous or intermittent. William James, whose pragmatic magic probably called the Peyote God to Harvard in the first place, had included shamanistic chemical visions among the many authentic "Varieties of Religious Experience." His student Gertrude Stein experimented in alteration of consciousness through mindfulness of language, an extremely effective Yoga since mechanical reproduction of language by XX Century had made language the dominant vehicle of civilized consciousness; her companion Alice B. Toklas contributed a cookbook recipe for Hashish Brownies to enlighten those persons over-talkative in drawing rooms unaware that "the medium is the message."

This synchronism is exquisite: William S. Burroughs also once of Harvard shared Miss Stein's mindfulness of the hypnotic drug-like power of language, and collaborated on cut-up rearrangement of stereotyped language forms with friend Brion Gysin, who recounts that he had originally given Miss Toklas the recipe for her famous Brownies. Burroughs among others had begun experiments with drug-shamanism after World War Two-for the author of "Naked Lunch" it was a pragmatic extension of his Cambridge interest in linguistic 
Anthropology. That same gnostic impulse broke through to clear consciousness simultaneously in many American cities: Gary Snyder realized the entire universe was "alive" one daybreak 1948 in Portland when a flight of birds rose out of the tree stillness in a gully by the city river, a natural vision-The masters of the Berkeley Renaissance read Gertrude Stein aloud and practiced Poetic kabbalah (charming synchronism that psychologist Timothy Leary met poets Jack Spicer and Robert Duncan in that same 1948 student scene)-Neal Cassady drove Jack Kerouac to Mexico in a prophetic automobile to see the physical body of America, the same Denver Cassady that one decade later drove Ken Kesey's Kosmos-patterned schoolbus on a Kafka-circus tour over the roads of the awakening nation-And that wakening began, some say, with the first saxophone cry of the new mode of black music which shook the walls of white city mind when Charles Parker lifted his birdflightnoted horn \& announced a new rhythm of thinking, an extended breathing of the body in music and speech, a new consciousness. For as Plato had said, "When the mode of the music changes, the walls of the city shake."

The new consciousness born in these States can be traced back through old gnostic texts, visions, artists \& shamans; it is the consciousness of our ground nature suppressed \& desecrated. It was always the secret tale of the tribe in America, this great scandal of the closing of the doors of perception on Nature's Naked Human Form Divine. It began with the white murder of Indian inhabitants of the ground, the theft and later usurious exploitation of their land, it continued with an assault on all races and species of Mother Nature herself and concludes today with total disruption of the ecology of the entire planet. No wonder black slaves kept for non-human use into this century in tear-gassed ghettos of megalopolis were the first Aliens to sound the horn of Change, the first Strangers to Call the Great Call through Basilides' many Heavens. Amazing synchronism again, that Mr. Frank Takes Gun, Native American Church amerindian Peyote Chief, invited the brilliantly talkative silver-haired psychiatrist who directed a Saskatchewan mental hospital in the early '50s to participate in a Peyote ritual, and that the same Dr. Humphry Osmond having recognized a wonder of consciousness thus experienced passed on the catalyst in Mescaline synthetic form to Aldous Huxley; and that Huxley's 1954 essay on the chemical opening of the Doors of Perception found its way to the tables of Bickford's Cafeteria Times Square New York \& the couches of Reed College and Berkeley, where artist persons, having heard the Great Call of the Blacks, already initiated themselves en masse to subtle gradations of their own consciousness experienced while puffing on the same Afric hemp smoked by Lester Young, Charles Parker, Thelonious Monk \& Dizzy Gillespie.

Dr. Timothy Leary takes up his part of the tale of the tribe in a Mexican hut and brings his discovery to Harvard harmoniously-and there begins the political battle, black and white magic become publicly visible for a generation. Dr. Leary is a hero of American consciousness. He began as a sophisticated academician, he encountered discoveries in his field which con- 
founded him and his own technology, he pursued his studies where attention commanded, he arrived beyond the boundaries of public knowledge. One might hesitate to say, like Socrates, like Galileo?-poor Dr. Leary, poor Earth! yet here we are in Science Fiction History, in the age of Hydrogen Bomb Apocalypse, the very Kali Yuga wherein man's stupidity so overwhelms the planet that ecological catastrophe begins to rehearse old tribe-tales of Karmaic retribution, Fire \& Flood \& Armageddon impending.

It would be natural (in fact deja vu) that the very technology stereotyping our consciousness \& desensitizing our perceptions should throw up its own antidote, an antidote synthetic such as LSD synchronous with mythic tribal Soma \& Peyote. Given such historic Comedy, who could emerge from Harvard technology but one and only Dr. Leary, a respectable human being, a worldly man faced with the task of a Messiah. Inevitable! Not merely because the whole field of mental psychology as a "science" had arrived at biochemistry anyway. It was inevitable because the whole professional civilized world, like Dr. Leary, was already faced with the Messianic task of accelerated evolution (i.e., psychosocial Revolution) including an alteration of human consciousness leading to the rapid mutation of social \& economic forms. This staggering realization, psychedelic, i.e., consciousness expanding \& mind-manifesting in itself, without the use of chemical catalysts, is now forced on all of us by images of our own unconscious rising from the streets of Chicago, where city teargas was dumped on Christ's very Cross in Lincoln Park AD 1968. The drains are backing up in the cities, smog noise and physiologic poison in food turns us to insect acts, overpopulation crazes the planet, our lakes corrupt, old riverways become dank fens, tanks enter Prague and Chicago streets simultaneous, Police State arrives in every major city, starvation wastes African provinces, Chinese genocide in Tibet mirrors American genocide in Vietnam, Alarm! Alarm! howls deep as any Biblic prophecy.

Ourselves caught in the giant machine are conditioned to its terms, only holy vision or technological catastrophe or revolution break "the mind-forg'd manacles." Given one by-product of the technology that might, as it were by feed-back, correct the berserk machine and liberate the inventor's mind from captivity by robot hypnosis, Dr. Leary had in LSD an invaluable civilized elixir. For, as Dr. Jiri Roubichek observed early in Prague ("Artificial Psychosis," 1958), "LSD inhibits conditioned reflexes." And this single phrase, for rational men, might be the key to the whole gnostic mystery of LSD and Dr. Leary's role as unique, alas solitary, courageous, humane \& frank public Democratic Boddhisatva-teacher of the uses of LSD in America. For he took on himself the noble task of announcing the evidence of his senses despite the scary contumely of fellow academicians, the dispraising timorous irony of scientific "professionals," the stupidity meanness self-serving cowardice and hollow vanity of bureaucratic personnel from Harvard Yard to Mexico City to Washington, from the ignorant Sheriff's office in Dutchess County NY to the inner greedy Gordon-Liddy-haunted sanctums of the US Treasury Department 
in D.C., our whole "establishment" of civilization that defends us from knowledge of our own unconscious by means of policemen's clubs, and would resist the liberation of our minds and bodies by any brutish means available including teargas, napalm \& the Hydrogen Bomb.

Dr. Leary conducted himself fairly \& equitably, given the extraordinary nature of his knowledge; it took an innocent courage to explore his own unconditioned consciousness, to take LSD and other chemicals often enough to balance praxis with explanation, and to attempt to wed the enormity of his experience to Reason. An heroic attempt to communicate clearly and openly through civilized technologic media to his fellow citizens, despite centuries of identity brainwash accelerated now to mass neurosis and Cold War Apocalypse Paranoia required of Dr. Leary the proverbial wisdom of serpent \& harmlessness of dove. . . .

Dr. Leary was jailed for theory and practice of research on LSD \& Cannabis. He took the burden of giving honest public report of LSD \& Cannabis in terms more accurate \& harmless than the faked science of the Government Party Hacks \& therefore his imprisonment was an act of insult to Science, Liberty, Common Sense, Freedom, Academy, Philosophy, Medicine, Psychology as an Art, and Poetry as a tradition of human mind-vision.

(Excerpted from the Preface to Timothy Leary's Jail Notes, 1968; 1970; revised, 1985.) 


\section{Preface}

\section{Timothy Leary}

My first meeting with Michael Horowitz occurred in the summer of 1970 when I was headquartered in a state prison faced with thirty years incarceration for a small amount of marijuana. Michael was interested in organizing my personal archives, a dozen or so file cabinets containing records of historical interest about the beginnings of humanist psychology in the 1950s and about the origins of the psychedelic drug culture in the 1960s. I was more than eager to turn these records over to Michael and his comrade Bob Barker because at that very moment I was busy planning a "midnight express" departure and feared that the archives would be seized by government agencies if and when the escape plot succeeded.

After the escape, during the years of exile, Michael became my closest link to the old country. He forwarded documents to me in Algeria, visited me in Switzerland and in various prisons where I was to be found after my recapture. By this time the archives contained records of historical interest about the cultural and political conflicts of the stormy 1970s.

During the 1980s our interaction has occurred in less melodramatic zones-under the redwoods in Michael's Mendocino commune, at Dodger Stadium, around the dinner table with Barbara Leary and our son Zachary and Michael's wife Cynthia and their children Sunyata, Jubal, Noni and Uri.

The publication of this conscientious, scholarly review of my varied "published" transmissions (1942-1986) is, for me, a celebration of this precious collaborative interaction. In looking over the manuscript I am overcome with admiration for Michael and Karen Walls and Billy Smith, that crack squad of "private investigators" who have dedicated so much time and talent to tracking down evidence, checking leads, interviewing witnesses, dusting for ink-stained fingerprints, patiently collecting clues from the scene of the time.

At this point it should be pointed out that Michael Horowitz is not an ivory-tower academic sitting in a musty library pouring over yellowing documents. Michael and his wise partner Cindy have been actively involved in the cultural events which are covered by this bibliography. They have had in-depth interactions with sages like Aldous Huxley and Albert Hofmann, shaman women, mainline ladies, alchemist poets. They were engaged participants in the San Francisco Renaissance. They conducted the "longest 
permanent-floating drug archive in history" (The Fitz Hugh Ludlow Memorial Library) all the while managing to perform numerous miracles of front-line scholarship.

According to the James Boswell Theory of History the true heroes of culture are those who preserve reality for the future-those who know precisely what our descendents must remember if they are to learn from us how to create better futures. These are the archivists, the literary archeologists, the bibliographers who preserve and transmit the idea of one time to another.

The twenty-first century, we are told, will be the Century of Information-Communication. The Golden Age of Psychology. The Time of Brain Power. If this comes to pass then Michael Horowitz could well become a legend. Indeed, the biography of Michael Horowitz could become a recognized classic of the twenty-first century. Come to think of it, in The Bibliography of Michael Horowitz the book which you hold in your hand would be just one item!

Reading this book has taught me a lot about myself. Reviewing this list of published transmissions spanning a period of some forty years I see a clear pattern of thematic repetition that is almost robotic. I am humbled to see that I have been a cheerful cricket in a summer garden scraping out one unchanging note. I can now recognize with embarrassment that my behavior has been predetermined as fixedly as the simplest tropism. Until very recently I have had little understanding or control of my behavior. I have been swept along by an evolutionary wave, enjoying the surf, that's true, feeling great about the surging motion which was surely moving us in the right direction, but still uncertain about where we were going.

There is one word which describes this genetic process of which I have been a passive, unwitting part: interaction. THIS BOOK IS A CATALOG OF IDEAS ABOUT INTERACTION TO WHICH CHILDREN BORN IN THE 1920S WERE EXPOSED.

This interactive stage in our development hit the western world at the turn of the century when Einstein focussed on the relationships among events. And quantum physics defined matter/energy as clusters of probabilities shuttling between on/off states. And Heisenberg pointed out that we can never study anything in nature; since our observations determine the event, all we can ever understand is the interactions we are involved in.

This notion of interaction was in the air when I arrived on the scene in 1920. Einstein's theories were debated in the popular press. It was said that only seven men in the world understood his equations but the meaning of "relativity" was seeping down into public consciousness. Moralists and educators began denouncing Einstein, probably sensing that if the basic concepts about how-the-universe-is-constructed change, then our ideas about ourselves may have to change. If atoms and protons and electrons and galaxies are not just passive reactive lumps of matter (as feudalism taught), and not sturdy, reliable billiard balls making up a universe manufactured by an engineer-entrepreneur 
god, himself dying of the black lung disease called entropy (as taught in Newton's Principia, the bible of the Industrial Revolution); if it turns out that every solidity which we forge into steel is made up of probability bits which cluster into the transient patterns we call matter, and if all these bits are continuously linked into high-energy interplay which continually changes all elements involved, then can the same be true of ourselves? And our societies? All our realities?

Can it be true that we are, each of us, quantum-units defined by our interactions, continually being shaped by the fields of interplay which we inhabit?

The book you are holding in your hand is a direct expression of these philosophic uncertainties which emerged in America during my childhood. Those born in the 1920s were unwitting members of the first wave of inexperienced, untrained shock-troops thrown into brain-to-brain confrontation with the quantum future. The first decade of my life was called "the Roaring Twenties" perhaps because these ancient Pythagorean-Taoist ideas about the nature of everything were just about to flame into realization. Become materialized.

The popular music of any era seems to reflect the stage of philosophic sophistication. The identifying music of the 1920s involved improvisation, innovation, a fusion of old earth African rhythms and modern technologies. In this music there were no composers and no leaders or conductors. There was this intense interaction among individual improvisors! It was called jazz.

I wonder if the early quantum physicists understood that their formulae about the universe would, within a few years, be passed on to the species in a new form of down-home music? Some of them did, I am sure. THIS BOOK IS A CATALOG OF IDEAS ABOUT INTERACTION WHICH THOSE BORN IN THE 1920S (IN AMERICA) INCULCATED INTO AND SAW REALIZED THROUGH THEIR CHILDREN.

An enduring cultural change happens when parents switch their books on baby and child care. Feudal parents treat their children as their Good Book says: as serf or chattel. Let us call them Children of God. The Lord's Kids.

The Industrial Age began when parents began raising their children according to the Newtonian version of the Bible, preparing them to play roles in the factory-civilization, training them to be dependable, reliable, productive, replaceable cogs in Management's Great Machine. Let us call them The Factory Kids.

The Great Philosopher of the Jazz Age was Dr. Benjamin Spock. In his quantum-mechanics version of the Good Book (originally entitled The Commonsense Book of Baby and Child Care), he said: Treat your children as individuals. Let them improvise and innovate. Harmonize and improvise with them.

Dr. Spock said: Your family members are not like the Vatican Choir, reciting the Gregorian Chant (or the Morman Tabernacle Choir). You as parents are not 
conductors of the Carnegie Hall Philharmonic Orchestra playing a symphony composed by a dead European.

Dr. Spock said: Swing to the beat of your own rhythm section. Stay in tune.

The children born after 1946 are often called The Spock Kids.

The books and articles which I wrote during the 1950s were direct spin-offs of the Spock Bible. The key term was interpersonal. The psychologist studied the field of interaction set up between the doctor and the patient. We were unwittingly moving towards a nuclear psychology, a quantum psychology, using "psychlotrons" to measure the behavior-bits which appeared when people collided with each other. We studied the relationships among clusters of behavior-bits. We defined personality as the everchanging patterns of interactions within the person and with others. There was much talk about feedback, indices of variability (discrepancy), multilevel assessments, individual patterns of self-determination.

During the 1960s a new field of interaction emerged: the interplay between the brain and the mind. Western psychologists were discovering that consciousness could be experimentally altered. The CIA, operating from a decidedly non-Spockian perspective, vainly attempted to use brain-change drugs for mind control. The Harvard Psychedelic Drug Research Group understood right from the start that reactions to psychoactive drugs were highly subjective, individualized. We demonstrated that the drug experience was determined by the interaction of set and setting. In the scientific mode there was much discussion about how the environment imprinted the brain and how these imprints determined the brain's interpretation of the environment; levels of consciousness, stages of imprinting, psycho-geometry. In the poetic-metaphorical mode there was much breathless writing about psycho-ecology, the "oneness," the holistic unity of everything. We were still operating, it seems to me, under the influence of The Commonsense Book of Baby and Child Care. The universe, it turned out, was like a Big Baby Boom family. The trendy thing for our young species to do at this stage in our evolution was to realize that it's all linked up and, if you learn how to listen, as Dr. Spock suggests, there's a lot to be learned.

There were many problems involved. The notion of demand feeding and reality menus did create some confusion. Many silly choices were selected. If you treat people (including yourself) as individuals some pretty strange singularities tend to pop out. This bibliography presents ample evidence of the goofiness and wild enthusiasm that gets stirred up when your Good Book encourages improvisation.

It is interesting to note that the managers of industrial America went along with the program. However distasteful they may have found the Good Doctor's prescription, management never failed to produce the goods and goodies demanded. The Spock Kids viewed the body as an instrument of pleasure and beauty-use it or lose it-so the enormous fitness-style-cosmetic industry emerged. As the first generation of the Information Age they wanted their brains stimulated-use it or lose it-so they got television, stereo, home video, transistors, satellite-dishes feeding electronic nourishment to hungry neurons. 
The personal Super-Knowledge-Information-Processing-Intelligence System (once called the computer) is the ultimate brain enrichment device. For our young species, the restless bipeds with the big heads, here's the new brain-powered mind-toy. The inevitable technological climax to the wave that the quantum physicists began back there at the turn of the century. The microprocessor can be seen as an external minibrain processing and feeding back clusters of on/off signals. Available for programming by external miniminds (the software).

These electronic minibrains are going to change everything. For starters they offer a nice transitional point to end this annotated list of wood-pulp information-carriers-books, pamphlets, broadsides, essays, bumper-stickers, posters-with some later transmissions on vinyl, celluloid and audio-video magnetic tape. Please note that the final publications listed in this book reflect the fact that for the last years I have been learning how to use this electronic brain-mirror which turns out to be designed for intensified interaction between human minds. While I shall never be willing or able to kick the rag-glue habit of the Gutenberg species, I have joyfully accepted the new definition of the human being. Homo sapiens: the Turing Person. Man/Woman the Knowledge-Information Processor.

The next bibliography will focus on the new form of knowledge exchange: Interactive Books. Commonsense Texts for Child Development. Books that are individualized, custom-programmed to be extensions of our minds.

We are not talking about desk-cluttering arrays of terminals and screens and keyboards and printers and disk-drives, that accumulated residue of the Industrial Age. We are talking electronic magazines, the size of Newsweek. The frontcover is the screen. Open up the pages, pop in your interactive texts, stick it in your pocket and head for school or the beach or the mountain trail. Every ghetto child, every Third World youngster will have one of these inexpensive superminds. Everyone in the world can be a Spock Kid with a pocket full of interactive brain-power.

The authors of this bibliography have taken the first beginning steps. The manuscript (electro-script) was prepared as a series of electronic off/on patterns stored on silicon chips and edited in the form of electronic signals on a video screen.

At this moment I am typing these thoughts into a computer from whence they will be modemed to Michael Horowitz and Karen Walls and Billy Smith and then transferred in silicon digital patterns to the printing presses that print the letters which are NOW hitting your retina. My brain and yours thus linked in electronic interaction.

The next time we meet this way I hope you'll be sending. . . .

Laurel Canyon

Los Angeles, California

December 1986 


\title{
Introduction
}

\author{
Frank Barron, Ph.D., Sc.D.
}

The actual behavior of mystics (and mystics do behave, even if out of sight) is traditionally mysterious to us ordinary folk. The basis on which they act is commonly considered beyond rational knowing. Mystics themselves often don't help matters any; they have been known to call their experiences "ineffable"- thus veiling them from people poking after substance-and even to speak of being Alone with the Alone-a very private sort of party. Yet upon close historical examination mystical movements are seen to have almost always a highly articulate rational analysis as at least a preliminary to their manifestation, if not the active base of the primary experience itself. (But is not all primary experience nonverbal?)

Timothy Leary would be the last, I think, to place himself in the camp of the mystics, but there is a tendency for readers of the daily newspapers to find his behavior incomprehensible. The kindest of his pragmatic-minded critics call him a mystic; the unkindest, a charlatan. His friends are more likely to think of him as a gentleman and scholar, as I do; with, of course, a streak of wild Irish rebellion, imagination, unconventionality, and love of battle. But whatever his character, personality, and religion, he unquestionably served as a catalyst in a time of major social change - a change in consciousness as well as a change in manners, the mysterious ' 60 s. Is his role to be understood only in terms of the experience of sacred mushrooms, magical potions, new chemical sacramental substances, and possible access to divine or diabolic energies?

In the present context I do not plan to speak to these deep matters; I have set myself rather to take a look once again at his ideas and their research support as presented by Dr. Leary and his co-workers in Berkeley and Cambridge in the 1950s and early 1960s in professional journals and at scientific meetings. This hardly warrants such a title as The Search for Timothy Leary (the actual title of a recent Ph.D. thesis at the University of Tennessee) or even The Timothy Leary No One Knows. It is simply a review of the work which found continuance and theoretical analyses when psychochemicals became for him an important new possibility in his decade-long search for ways of helping people who suffered from psychological adversities (who suffered pain, i.e., which a new medicine might relieve).

A long search. "Search" was a favorite word of Tim's in the years in which I worked closely with him. Sometimes he contrasted it favorably with research, for research smacked too much of the academic and abstract. Research was of 
books and the intellect, search was of life and intuition. Yet books he did write, and research he did conduct; voluminously, as this annotated bibliography lets us know. But still he thought of himself, then as now in 1987, as a searcher-Ecclesiastes was his favorite reading in the Old Testament (which like a good Gnostic he abhorred), and his words would have been one with those of the Preacher: "Of making books there is no end." A fine and fitting epigraph for a bibliography!

My own contribution to this literature is filed in good libraries under the rubric "creativity" rather than psychotherapy or psychodiagnosis, but it issued from the same sources as the Leary opus and at times we coauthored publications or collaborated as partners in research. This collaboration extended from 1950 and Leary's work at Permanente Clinic in Oakland-I was consultant there for five years and contributed various measures to the core diagnostic battery for Interpersonal Diagnosis of Personality - to the Psychedelic Research Project at Harvard in 1960-61, of which I was co-director for that year. The coauthored paper cited here, "Changes in Psychoneurotic Patients With and Without Psychotherapy," stemmed equally from my own prognostic indices developed as part of my Ph.D. thesis at Langley Porter Clinic and the intensive Permanente studies of the effect of psychotherapy in the Leary-Permanente project, which was funded for several years by the National Institute of Mental Health. It was the first psychometrically based study of psychotherapy to employ carefully matched control groups, and its conclusion-that on the average, and discounting an increase in ups and downs during therapy, the effects of extended (six months) conventional psychotherapy were rather slight-was terribly discouraging to Tim, I remember. In retrospect, it was one of the major influences in what became for him a really zealous search for new methods.

Search, once again. The other formally researched topic we shared was an attempt, partially successful, to increase creative behavior in people by feeding back to them the results of their own performances on tests of creative thinking and of related measures of attitudes known to be instrumental to creative thinking (e.g., independence of judgment, complexity of outlook, unconventionality). This paper is titled "Effects of Test Score Feedback in Creative Performance," and Tim presented the findings of our research at a National Science Foundation conference sponsored by the University of Utah in 1962 (1964, Widening Horizons in Creativity, Calvin W. Taylor, ed.). This was our last formal collaboration before the roof fell in at Harvard in 1963 for LSD, Leary and Alpert, and what by then was a new host of explorers of unusual states of consciousness (in the long psychedelic procession at Cambridge, from James, Myers, and Prince to Murray and MacKinnon). By that time I had returned to Berkeley and had turned my attention to creativity in mountain climbers. (As an aside on the time, I might mention that one of my colleagues, James T. Lester, Jr., project director for the mountaineering research, accompanied, step-by-step, to the upper slopes of Mount Everest the 1963 team which made the first successful American ascent, and from Ad- 
vanced Base Camp at 23,500 feet wrote back to me, "Frank, I may not be the best psychologist in the world but I know I'm the highest - with my feet on the ground, that is!")

High times indeed were the order of the day, and I leave the commentary on that half of this Gemini-like bibliography introduction to Allen Ginsberg. It is to the Timothy Leary whose feet were certainly on the ground, in the spade work as well as the grand construction of Interpersonal Diagnosis of Personality, that I now return.

Leary's enduring contribution to psychodiagnosis, or, more generally, to the typology of personality, is embodied in his honored 1957 volume, Interpersonal Diagnosis of Personality. In Leary's own terms, the emphases were on multilevel aspects of interpersonal dimensions: five levels discernible in his data, ranging from public communication to personal-social conscious communication, private perception, the unexpressed (rather than repressed), and the level of values. For each level he found a characteristic unit of analysis, respectively: the interpersonal reflex, the interpersonal trait, the interpersonal symbol, the significantly omitted communication, and the ego-ideal. This was a giant step forward for typologies, which at that time were completely lacking in a hypothetical hierarchical structure and were almost always locked in to the single-person trait. Henry A. Murray and collaborators in the famous Explorations in Personality deliberately chose the alphabet as their ordering principle for lists of variables! The concept of levels was implicit in sophisticated personality descriptions, and degrees of consciousness were recognized in all the psychodynamically based systems, but none were connected systematically through the concept of interpersonal behavior as in the Leary system. Nor had any of the early efforts achieved the operationalizing of their terms through insistent psychometric definitions, with an extensive empirical, observational database, as in Interpersonal Diagnosis of Personality.

This was, of course, a group effort. Dozens of psychologists, psychiatrists, and social workers provided the professionally refined observations necessary for the statistical analyses, and literally hundreds of patients in group psychotherapy themselves provided ratings as well as serving as subjects. Teamwork was by then the expected thing in the physical sciences, and particularly so at the University of California, whose Los Alamos and Berkeley campuses housed the major components of the Manhattan Project; but teams such as the Leary-Permanente group, and of course the Berkeley and Oakland Growth Studies, were new instruments of research in the social sciences. It was out of this heady University of California atmosphere that the first collaborative Ph.D. theses in psychology came. Leary, Mervin B. Freedman, Abel G. Ossorio, and others, under the direction of Hubert S. Coffey and Jean Walker Macfarlane, shared subjects, data, and theory in a pioneering collaborative effort in the late 1940s. For Timothy Francis Leary it culminated in the dissertation, The Social Dimensions of Personality: Group Structure and Process, which earned him his Ph.D. in 1950. For this work he was to be honored within the year by election to Phi Beta Kappa. 
The importance of the setting, in social and psychological terms, as a determinant of group process, became a cardinal principle later in Dr. Leary's definition of the constructive psychedelic session. Set and setting were the key words in transforming the "psychotomimetic drugs" to psychedelic sacramental psychochemicals. A sense of the sacred, derived from the Navajo communal rites with peyote and the Mazatec Indian use of the sacred mushroom, combined with a twentieth century urban-university faculty-home assurance of psychological safety, were the important aspects of the setting. And the "set" was one of exploration of the mysteries of mind and spirit.

Acid in the street for all comers is a far cry from selective participation of already mentally advanced and creative artists, scientists, philosophers, intellectuals and curious, alert students at Harvard. Talk about change! It would be easy to decry this radical democratization of the psychochemical process for which mystics of past ages prepared by years of spiritual discipline; but "the times, they (were) a-changing." The accounts are far from closed on that psychedelic voyage of a whole generation. Timothy Leary showed himself in another role in this movement, but one that was hardly hidden from those who knew him well in the preceding two decades. He is a populist reformer and leader in the tradition of LaFollette, and a propagandist for freedom in the tradition of Mark Twain and Harriet Beecher Stowe. His own ego-ideals (or at least the chief figures in his pantheon) are Huck Finn and James Joyce and Aleister Crowley, as well as Dante and Thomas Aquinas. Timothy, after all, has had a Jesuit education, which provides pros and cons for every question. (I was amused recently to read that W. B. Yeats, a higher-order magician of the Order of the Golden Dawn, whose ladder Crowley was on, dismissed Aleister, also known as Holy Ed, with the lofty statement: "This is a mystical order, not a reformatory." Tim Leary somehow never made tenure on either the academic or mystic ladders, a fact which I feel sure makes him both proud and happy.

That he was also to see the inside of reformatories is another matter. He has managed in his autobiography to write without tears of solitary confinement, and he certainly emerged (more than once, it must be admitted) from behind the walls with his spirit undaunted and his scientific and altruistic energies undiminished. His new contributions (for this is a bibliography in progress) are in the area of "brain games" for computer software, the mental change-agents of the $80 \mathrm{~s}$. The themes of individual freedom, choice, change, growth of consciousness and intelligence, remain the constants in this lifetime of contributions.

Department of Psychology University of California Santa Cruz January 1987 


\section{Acknowledgments}

We are very grateful to the many people who aided our research during the seven years we spent compiling and annotating this bibliography. Timothy Leary was a source of neverfailing support and historical information. We are grateful both to him and to Dr. Frank Barron for their original preface and introduction, as well as to Allen Ginsberg for revising and updating a piece he wrote in 1968 so that it could serve as a foreword.

Barbara Rootenberg of B. \& L. Rootenberg Rare Books was most gracious in allowing us access to Dr. Leary's archive where many of his rare and early works are stored. The directors of the Fitz Hugh Ludlow Memorial Library-Michael and Michelle Aldrich, Robert and Kay Barker, William Dailey and Cindy Palmer Horowitz-must be thanked for their efforts in building the Leary collection as part of the library's large holding on the psychedelic movement.

George Koopman (coauthor of Neuropolitics and president of American Rockets) allowed us to use his substantial archive of Dr. Leary's work from the late '70s to early '80s. Jeffrey Miller, author of Paul Bowles: A Descriptive Bibliography, was very helpful with bibliographical advice. Michael Starks, author of Cocaine Fiends and Reefer Madness, a superb illustrated history of drug movies, provided important data on Leary's film appearances.

Numerous book scouts and antiquarian booksellers were sources of valuable information. In this area we must particularly thank David Sachs-Books, Dorothy Sloan-Books, Serendipity Books (Peter Howard, Nancy Kosenka, Tom Goldwasser and Burton Weiss), Joseph the Provider-Books (Ralph Sipper), Louis Collins-Books, Michael Good-Books, Michael Shields, Anne-Marie Bates, Carol McKusick, Rena Blumberg, Jim Clark, James Musser, Naicul Sucram, Ron Davis, Jennifer Jaques, Rickio Woods, and Jon White.

Information on German and Swiss editions was generously provided by Dieter Hagenbach, Susanne Seiler and Julia Summermatter Jus. Drs. Oscar Janiger, Michael R. Aldrich, Ralph Metzner and Ronald Siegel allowed us to examine some rare Leary items in their personal libraries. Many other booksellers, librarians and editorial assistants provided a fact when it counted; we are sorry we cannot thank them all by name. 
We wish to thank our publishers James Thorpe III and Diantha C. Thorpe for sharing and supporting our vision of this bibliography, and for their assistance in helping us implement it.

Michael Horowitz wishes to thank the person who introduced him to bibliographical studies in the early 1960s: Dr. Joel W. Egerer, bibliographer of Robert Burns and professor of romantic literature at Washington Square College, New York; and the late Warren R. Howell, who thoughtfully surrounded him with bibliographies at John Howell-Books, San Francisco, from 1968 to 1984.

Special personal thanks to Barbara Leary and Zachary Chase; to Cindy, Sunyata, Jubal, Noni and Uri; to Suzette and Joaquin; and to the Morrow Designs "Decision I" computer and Select Word-Processing Program: the high tech tools that greatly facilitated the compilation of this bibliography.

\section{Michael Horowitz Karen Walls Billy Smith}

Elk, Guerneville, Berkeley, Petaluma, Valley Ford, Novato and Black Point, California 1979 - July 4, 1987 


\section{Editors' Note}

Dr. Leary's varied career as social scientist, activist philosopher, man-of-letters and entertainer; the ephemeral nature of many of his academic and underground publications; and his interest in alternate forms of communication (records and tapes, films, software, etc.) have sometimes posed interesting bibliographical problems for the compilers of this work.

For example, while he was working in the department of psychology and social relations at Harvard University, Leary's research papers and talks first appeared in mimeographed form, then in journals and in offprints from journals, and later in magazines, anthologies or collections of the author's works-sometimes in different versions and under different titles. It has been Leary's practice to revise and update texts whenever the opportunity arises.

The fact that quite a number of Leary's works were written and published underground while he was in prison or exile has also complicated matters, making it difficult to sort out various states and issues. The essay Neurologic, for example, first appeared in photocopy form (in two issues), then went through two underground editions, the second in five states, before the first edition from type appeared-all in the year 1973. A piece that he wrote upon escaping from prison in 1970, reprinted frequently in underground newspapers and later in anthologies, originally appeared as a handwritten note left in his prison cell and served as an exhibit at his trial for escape three years later.

First appearances of some of Leary's articles in the underground press are sometimes difficult to establish, because of the peculiar dating practices of these newspapers. Leary usually revised the texts of his magazine articles when they later appeared in book form. A definitive edition of Leary's writings someday will be an editor's challenging task.

As a controversial public figure, Leary found himself cutting records and appearing on stage, on television and in films; his image appeared on posters and his slogans were written on buttons and bumper stickers. We have endeavored to track down these items.

Because Leary gave so many interviews during the course of his career, the compilers have established a separate section (D) for them, rather than listing them with other magazine appearances. In addition, we have regarded his initial software publication, Mind Mirror, as an "electronic book" and placed it in Section A with his other major books. 
We have established Section AA for mimeographed papers and offprints that represent trial or advance printings distributed in limited numbers to the author's colleagues. Offprints are cross-referenced to their periodical appearances listed in Section C.

In Section B we have placed all first book appearances, even if some of these essays and articles had previously appeared in journals and magazines. We have established Section BB for books containing material that has been reprinted from other books.

We have grouped foreign translations alphabetically by language, and included therein books and articles together in chronological arrangement.

We have endeavored to include in Section J significant references to Leary's work and/or activities in books or magazine articles, as well as any printed references to him by significant persons. The few books entirely devoted to Leary are mixed in chronologically with the voluminous number of periodical and book references. Within each year, journal and magazine appearances are listed chronologically by week or month, followed by book references in alphabetical order by author's last name.

Because the compilers feel that Dr. Leary's numerous trials for drug offenses have been and will continue to be of political and legal importance, we have listed all of these that we could find. Another reason for listing them is that Leary took an increasingly active role in his own legal defense. In one instance - his courtroom testimony at his trial for prison escape in 1973-Leary presented for the first time in print (i.e., court stenographer's record), the main ideas that appeared in his seminal essay Neurologic, published subsequent to his conviction.

The compilers were fortunate to have access to the Leary holdings in the Fitz Hugh Ludlow Memorial Library, undoubtedly the most complete in existence. The mimeographed papers, journals and offprints from his first publication in 1942 through his work as a research psychologist at the Kaiser Foundation in Oakland during the 1950s, and his psychedelic drug research at Harvard in the early 1960s, were largely provided from Dr. Leary's own archives. We were able to examine personally nearly every item listed; the very few we could not locate are noted as "not seen." 


\section{A. \\ Books, Pamphlets and Computer Software}

First edition:

BLACKFRIAR SERIES OF ORIGINAL PLAYS/ Lester Raines, Editor/ No. 48/ "PRELUDE TO NOTHING"/ A drama in one act by/ HAROLD COOPERMAN and TIMOTHY F. LEARY/ LESTER RAINES/ P. O. Box 276/ University, Alabama

$11 \times 8 \frac{1}{2}$ in. 12 leaves, printed on one side only.

[1] title; 2 Cast of Characters; 3-12 text.

Light blue wrappers, printed in green; rust-colored paper spine covering three staples. Front cover: (within border of inner rule and outer scroll): Blackfriar Series of Original Plays/ EDITED BY LESTER RAINES/ (device of Alabama Blackfriars)/ No. 48/ "PRELUDE TO NOTHING"/ A Drama in One Act/ by/ HAROLD COOPERMAN and TIMOTHY F. LEARY.

Mimeographed from typescript. Published 1942. Approximately 300 copies printed and distributed to American college libraries.

Leary's first separately published work is a play written in collaboration with a classmate at the University of Alabama. The subject is the psychological struggle of a young pianist disfigured in a wartime air raid. The play was produced and ran for six performances. 


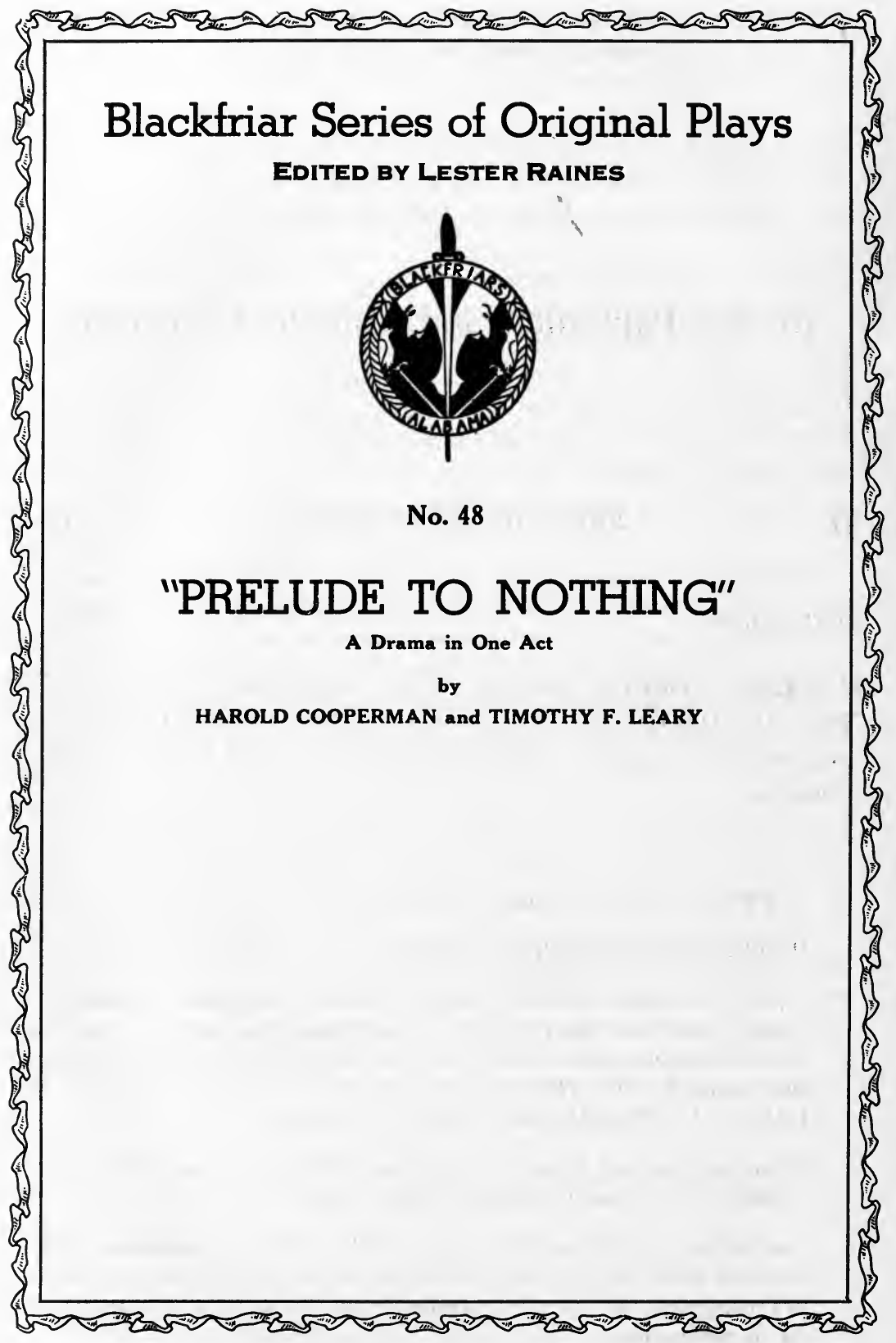

A1: Leary's first separately published work (1942), a collaboration. Courtesy Timothy Leary. 

OF INTERPERSONAL BEHAVIOR

a. First edition, first printing:

Multilevel Measurement of/ Interpersonal Behavior/ (bar) / A MANUAL FOR THE USE/ OF THE INTERPERSONAL/ SYSTEM OF PERSONALITY/ by TIMOTHY LEARY, Ph.D./ Director: Kaiser Foundation Psychology Research/ With the collaboration of/ Helen Lane, Research Administrator/ Anne Apfelbaum, Projects Manager/ Mary della Cioppa, Projects Manager/ Charlotte Kaufmann, Manager of Publication/ (bar) / Psychological Consultation Service - Berkeley, California, 1956/ (bar)

$11 \times 8 \frac{1}{2}$ in. viii, $110 \mathrm{pp}$.

[i] half-title; [ii] blank; [iii] title; [iv] FIRST EDITION/ Copyright 1956 by/ TIMOTHY LEARY/ Printed in the United States of America; [v] author's introduction; [vi] blank; vii Table of Contents; [viii] blank; 1-110 text. Included in the text are forty-eight tables, seventeen text figures, and one folding chart (Interpersonal Check List) constituting pp. 13-14 (chart is folded twice and bound with text facing p. 15).

Light blue laid paper wrappers, printed in black on front cover: MULTILEVEL MEASUREMENT/ OF/ INTERPERSONAL BEHAVIOR/ TIMOTHY LEARY, PH.D. Sheets stapled under wrappers.

Published 1956. 1,000 copies printed.

Note: In copy examined, preliminary leaves were misbound, with half-title following title and contents preceding preface.

b. First edition, second printing:

Collates identically to A2a, except that the folding chart (pp. 13-14) is folded once and bound in with the text facing p. 12.

Blue (color noticeably darker than in A2a) textured paper wrappers, printed in black identically to A2a. Perfect bound, no staples visible.

Second and subsequent (indistinguishable) printings were published in 1957-58 (number unknown). Copies were sold at $\$ 12.50$ by mail order; the price later dropped to $\$ 7.50$. The four record booklets (figs. 5, 6, 7 and 14) were printed separately between Feb. and Dec. 1955 prior to their inclusion in the Manual. These record books were designated as follows: 
(1) The Interpersonal Check List. Folded sheet. Pp. [1-3] text; [4] blank. At foot of p. [1]: This booklet has been prepared by Timothy Leary, Ph.D., and published by the Psychological Consultation Service, 1230 Queens Road, Berkeley 8, California. The Interpersonal Check List was developed by Rolfe LaForge, Ph.D., and Robert Suczek, Ph.D., and other staff members of the Kaiser Foundation Research Project in Psychology. Price: 20 for $\$ 4.00$ to 500 for $\$ 35.00$.

(2) Record Booklet for/ Interpersonal Diagnosis of Personality. Folded sheet. Pp. 1-4 text. At foot of p.[1]: This booklet was prepared by Timothy Leary, Ph.D., and published by the Psychological Consultation Service. Price: 20 for $\$ 5.00$ to 500 for $\$ 50.00$.

(3) Record Booklet for/ Interpersonal Analysis of Group Dynamics. Folded sheet. Pp. $1-4$ text. Price: 20 for $\$ 5.00$ to 500 for $\$ 50.00$.

(4) Record Booklet for/ Interpersonal Diagnosis of Family Dynamics. Two folded sheets. Pp. 1-6 text. Price: 20 for $\$ 5.00$ to 500 for $\$ 50.00$.

Template 1 for scoring the Interpersonal Check List (1) was produced in 1955; it measures $97 / 8 \times 12 \frac{1}{4}$ in. Template 2 for overlaying the diagnostic grid was produced in 1956; it measures $11 \times 8 \frac{1}{2}$ in. Templates sold for $\$ 3.00$.

Picture cards for the Interpersonal Fantasy Test described on p. 110 were produced in Dec. 1955. These cards, designed by Leary, are variations of images used in the TAT. The test calls for a total of thirty-two cards; a promotional brochure of four pages published in 1956 describes the test as comprising "26 TAT-type cards . . . [ [which] will be published later." Publication of twenty-six cards, with five-page typewritten manual, price $\$ 15.00$, in $1957-58$ is referenced in $\mathrm{J} 218 \mathrm{a}$.

Manual and Record Booklets are described in a four-page prospectus issued with an order blank. This prospectus was later reissued in two-page format. The four record booklets were later distributed by Unitas Publications, Cambridge, Mass. (1960-61), and still later they were reprinted and distributed by University Books, New Hyde Park, N.Y. (1963).

This manual was written in conjunction with-but published slightly earlier than-Interpersonal Diagnosis of Personality (A3). "The theoretical background of this system of personality, the current research findings, and the clinical application are described in detail in a book, 'The Interpersonal Diagnosis of Personality.' The use of the interpersonal system and of this manual will be greatly facilitated by an acquaintance with this book" (pp. 1-3). References in the text to the aforementioned book give the erroneous publication date 1956.

The Psychological Consultation Service was initially located in the author's home in the Berkeley Hills. Later on, it operated from Cambridge, Mass., New Hyde Park, N.Y., and San Francisco, Calif. Requests for the manual and related booklets came from the United States and abroad. This test was given to Leary in a California prison some fifteen years after he formulated it. 
Multilevel Measurement of
Interpersonal Bebavior

A MANUAL FOR THE USE OF THE INTERPERSONAL SYSTEM OF PERSONALITY

by TIMOTHY LEARY, Ph.D. Director: Kaiser Foundation Psychology Research

With the collaboration of

Helen Lane, Research Administrator Anne Apfelbaum, Projects Manager

Mary della Cioppa, Projects Manager

Charlotte Kaufmann, Manager of Publication

Psychological Consultation Service - Berkeley, California, 1956

A2a: The tests he designed for this manual (1956) were given to Leary himself in prison fourteen years later. Courtesy Timothy Leary.

\section{A3 INTERPERSONAL DIAGNOSIS OF PERSONALITY 1957}

First edition:

Interpersonal Diagnosis/ of/ Personality/ A Functional Theory and Methodology/ for Personality Evaluation/ TIMOTHY LEARY/ DIRECTOR OF PSYCHOLOGY RESEARCH/ KAISER FOUNDATION HOSPITAL/ OAKLAND, CALIFORNIA/ THE RONALD PRESS COMPANY (small ornament) NEW YORK 


\section{I. $(\mathrm{T} . \mathrm{RI}$}

Interpersonal

Diagnosis

of

Personality

\section{Interpersonal Diagnosis of}

\section{PERSONALITY}

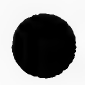

TIMOTHY LEARY

DIRECTOR OF PSYCHOLOGY RESEARCH

KAISER FOUNDATION HOSPITAL

OAKLAND, CALIFORNLA

RONALD

THE RONALD PRESS COMPANY - NEW YORK

A3: The rare dust jacket of Leary's first book. Courtesy Timothy Leary. 
$9 \times 57 / 8$ in. $x x, 522 \mathrm{pp}$.

[*1-2] blank; [i] title; [ii] Copyright, C , 1957 by/ THE RONALD PRESS COMPANY/ (short rule)/ All Rights Reserved/ (four-line statement regarding permission to reprint)/ Library of Congress Catalog Card Number: 56-10926/ PRINTED IN THE UNITED STATES OF AMERICA; [iii] dedication (to Marianne Leary); [iv] blank; v-vi Preface dated Oct. 1956; vii-ix Contents; [x] blank; xi-xii Figures; xiii-xv Tables; [xvi] blank; xvii-xix Introduction; [xx] blank; [1]-500 text; 501-18 Index; [519-22] blank.

Red cloth, stamped in gilt on spine: (double rule, the upper one thick)/ (single rule)/ INTERPERSONAL DIAGNOSIS/ OF/ PERSONALITY/ (short rule)/ LEARY/ (single rule)/ RONALD/ (double rule, the lower one thick). White endpapers. Dust jacket beige printed in dark blue, giving title, author, and publisher (front panel reproduces text of title page). Dark blue band and circular ornament on spine; back and inside panels blank.

Published Jan. 8, $1957 @ \$ 12.00 .1,000$ copies printed. This book has remained in print since it was published. It was reprinted twice by Ronald Press, for a combined total of approximately 6,300 copies. The rights were sold to John Wiley and Sons, which put out two printings.1,050 copies were published Dec.1977@ \$16.95 and 500 copies in Apr. $1982 @ \$ 32.95$. Available in the United Kingdom in $1982 @ £ 21.40$.

Later printings measure $87 / 8 \times 57 / 8$ in.; the cloth is darker red; there is no small ornament in the imprint at the foot of the title; on the copyright page is printed: $2 \mathrm{MP}$, 3MP, 4MP or 5MP, indicating second through fifth printings.

Leary's first full-length book summarizes the experimental studies in interpersonal behavior performed by the author and his associates at the Kaiser Foundation Psychological Research Center in Oakland between 1950 and 1956. Many of the projects were supported by grants from the U.S. Public Health Service.

The Annual Review of Psychology (1958) called this "perhaps the most important clinical book to appear this year. . . . Rarely has psychology found a way of placing so many different data into the same schematic system, and the implications of this are potentially breathtaking!"

\section{a. First edition:}

THE/ PSYCHEDELIC/ EXPERIENCE/ (single rule)/ A MANUAL BASED ON THE TIBETAN BOOK OF THE DEAD/ TIMOTHY LEARY, Ph.D./ RALPH METZNER, Ph.D./ RICHARD ALPERT, Ph.D./ (rule, thicker in center)/ UNIVERSITY BOOKS (device) New Hyde Park, New York 
$93 / 16 \times 77 / 8$ in. $160 \mathrm{pp}$.

[1] half-title; [2] large decorative Tibetan motif; [3] title; [4] PSYCHEDELIC MONOGRAPH I/ The first in a series of monographs, edited by Dr. Ralph Metzner./ COPYRIGHT (C) 1964 BY TIMOTHY LEARY, RALPH METZNER, RICHARD ALPERT/ Library of Congress Catalog Number: 64-19705/ Printed in the United States of America/ (2 lines pertaining to the cover illustration and endpapers, followed by 5 lines pertaining to the text used in this adaptation); [5] dedication (to Aldous Huxley, followed by twenty-two-line quotation from The Doors of Perception); [6] blank; [7-8] Contents; [9] fly-title to General Introduction; [10] blank; 11-31 General Introduction ; [32] blank; [33] fly-title; [34] blank; 35-159 text; [160] blank.

Black and red cloth, printed in green, black and white. Front cover: THE/ PSYCHEDELIC/ EXPERIENCE/ A MANUAL BASED ON THE TIBETAN BOOK OF THE DEAD / BY/ TIMOTHY LEARY, Ph.D./ RALPH METZNER, Ph.D./ RICHARD ALPERT, Ph.D./ (at right, seven lines of text referring to the authors' dismissal from Harvard because of their experiments with psychedelic drugs; at left, a photographic illustration, by Allen Atwell, of a portion of an 18th-century bronze of Hevajra Buddha in ecstatic union with his Shakti). Back cover: price at upper left; Tibetan religious motif (same as half-title); ten lines of publisher's blurb. Spine (printed vertically:) THE PSYCHEDELIC EXPERIENCE/ (horizontally:) publisher's device/ (vertically:) UNIVERSITY/ BOOKS. Red endpapers printed in black with details from an abstract drawing by Bruce Conner. Top edge stained red. Issued without dust jacket.

Published Aug. $1964 @ \$ 5.00 .10,000$ copies printed. There were eight subsequent hardcover printings between 1964 and 1972, as follows:

Second printing: Sept. 1964, 10,000 copies @ \$5.00.

Third printing: Aug. 1965, 10,000 copies@ @ \$5.00.

Fourth printing: Mar. 1966, 5,000 copies@ @ \$5.00.

Fifth printing: Jan. 1969, 5,000 copies@\$5.00.

Sixth printing: Nov. 1969, 5,000 copies@\$5.00.

Seventh printing: May 1970, 5,000 copies@ @ $\$ 5.00$.

Eighth printing: Jan. 1971, 5,000 copies@ @ \$5.00.

Ninth printing: May 1972, 5,000 copies@ @ \$6.00.

Later printings are identical to the first, except for the statement of subsequent printing on p. [4]. The top edge is stained red on the first three printings, not on the fourth and later printings. Some copies of the fourth and all copies of subsequent printings have white endpapers.

A total of 60,000 hardbound copies were published and in circulation despite the fact that possession of LSD and most other psychedelic drugs was outlawed on October 6, 1966.

"Ninth Printing May 1972" reproduced from IBM selectric type on p. [4], not from typeface as in first eight printings. Price of this printing raised to $\$ 6.00$. 


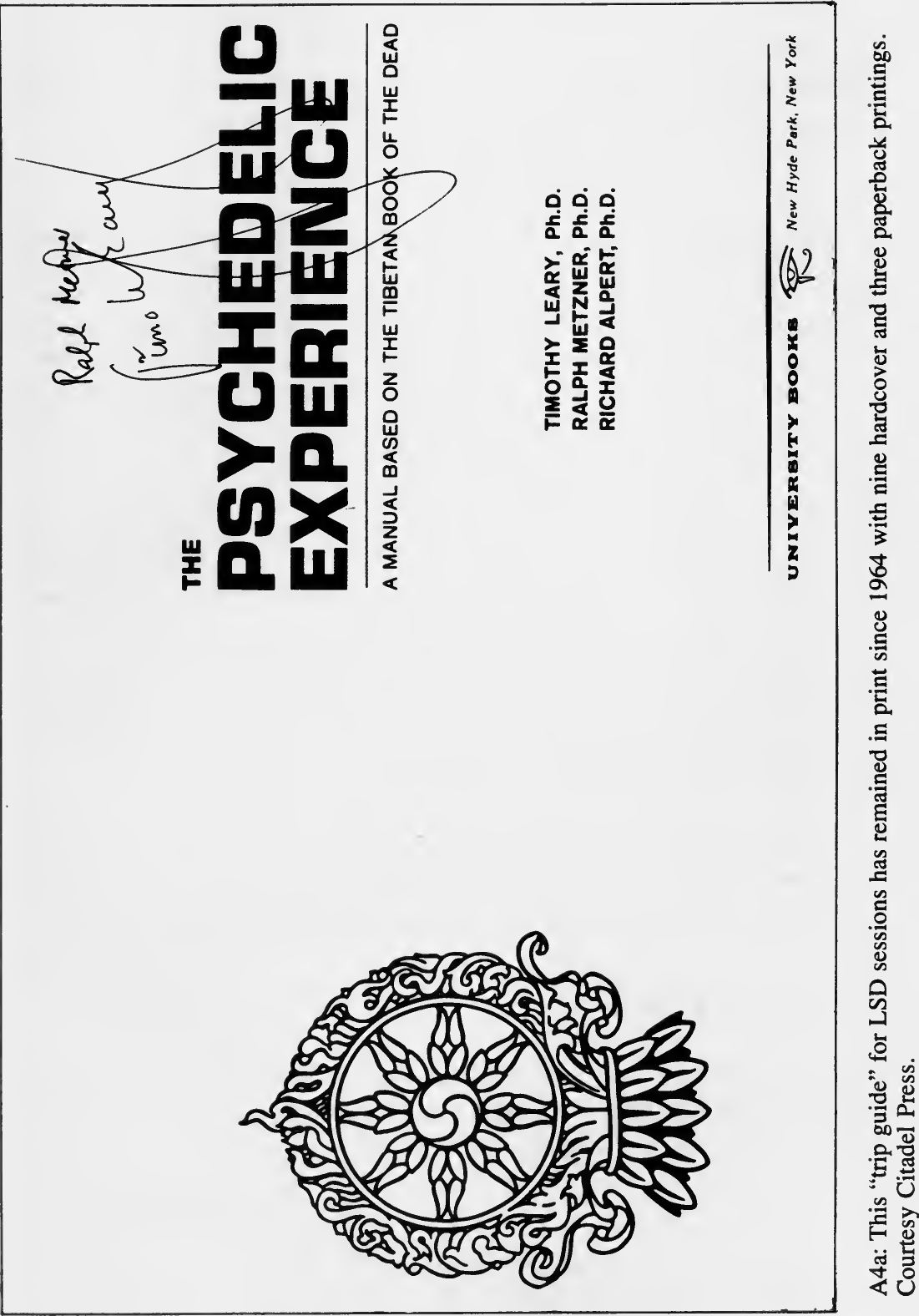


THE/ PSYCHEDELIC/ EXPERIENCE/ (single rule)/ A MANUAL BASED ON THE TIBETAN BOOK OF THE DEAD/ TIMOTHY LEARY, Ph.D./ RALPH METZNER, Ph.D./ RICHARD ALPERT, Ph.D./ (rule, thicker in center)/ The Citadel Press $\bullet$ Secaucus, New Jersey

$9 \times 63 / 8$ in. $160 \mathrm{pp}$.

Reduced photo-offset printing of A4a, to which it collates identically, except for change in title imprint and p. [4] which, following hardbound printing history in nine lines, reads as follows: First paperbound printing, Oct. 1976/ Copyright $\mathbb{C}$ 1964 by Timothy Leary, Ralph Metzner, Richard Alpert/ All rights reserved/ Published by Citadel Press/ A division of Lyle Stuart, Inc./ 120 Enterprise Ave., Secaucus, N.J. 07094/ In Canada: George J. McLeod Limited, Toronto/ Manufactured in the United States of America/ ISBN 0-8065-0552-4/ (five lines pertaining to the text used in this adaptation).

The binding is similar to that of the hardbound edition with the following main variations: Front cover: Tibetan religious motif is used in place of the bronze sculpture; authors' names and publisher's blurb reset in a different typeface; the price appears in the upper right corner. Back cover: text reset, imprint added. Spine: deletes imprint.

Published Oct. $1976 @ \$ 3.95 .4,000$ copies printed. A second printing of 3,500 copies was done in Sept. 1977, designated "Second paperbound printing" on p. [4]. A third printing of 4,000 copies was done in June 1983, designated "Third paperbound printing" on $\mathrm{p}$. [4], with the price raised to $\$ 4.95$.

There is an eighty-five-page typescript version entitled: "Tibetan Manual for Ego-Transcendent Experience Using Psychedelic Substances. Adapted from The Tibetan Book of the Dead. 3rd revision IFIF. Zihuatenejo, Mex. (1962). Antigua, BWI (1963)."

\section{c. First British edition:}

THE/ PSYCHEDELIC/ EXPERIENCE/ A MANUAL BASED ON/ THE/ TIBETAN BOOK OF THE DEAD/ BY/ TIMOTHY LEARY/ RALPH METZNER/ RICHARD ALPERT/ ACADEMY EDITIONS

$11 \times 8 \frac{1}{2}$ in. $96 \mathrm{pp}$.

[1] half-title; [2] Tibetan motif (identical to that used in American editions); [3] title; [4] (C) 1964 by Timothy Leary, Ralph Metzner, Richard Alpert/ Published by arrangement with Lyle Stuart-New York/ First published in Great Britain 1971/ by Academy Editions Holland Street London W8/ Printed by The Pitman Press, Bath/ ISBN 0-902620 207 cloth/ ISBN 0902620215 paper/ (three lines 
pertaining to the text used in this adaptation); [5] dedication (identical to A4a); [6] blank; [7-8] contents; 9-94 text with sidenotes; [95-96] blank.

White, glossy, stiff wrappers. Front cover: text (identical to title page) printed in black over Tibetan motif printed in red. Back cover: publisher's ads printed in black. Spine: (printed vertically:) PSYCHEDELIC EXPERIENCE academy. Pasted on front cover, upper right, is a small circular sticker with printed price.

Published Nov.1971@ @1.10. Undisclosed number of copies printed.

Reprinted in 1972 and 1973. In print in $1982 @ £ 4.95$. The 1973 printing is one-half inch taller and has a different cover design, employing an ancient Tibetan mandala on front and religious image on back, beneath a blurb calling this work "a classic text of psychedelic literature." Text and pictorial designs printed in white on glossy, orange, stiff wrappers. No price stated.

The authors, who were at the time affiliated with IFIF (International Federation for Internal Freedom), adapted the text of the W. Y. Evans-Wentz translation of The Tibetan Book of the Dead for use during a psychedelic session. Prior to publication, the authors sent the manuscript of this book to Aldous and Laura Huxley in Los Angeles. In This Timeless Moment (1968), Laura Huxley relates how she administered a dose of LSD to her husband, at his request, and read him portions of the Leary-Metzner-Alpert manuscript in the hours preceding his death on Nov. 22, 1963. The work is dedicated to Aldous Huxley, and contains "tributes" to Evans-Wentz, C. G. Jung and Lama Govinda. Following the introductory material, the text is divided in three parts: a description of the stages of a psychedelic experience in terms of the Bardo Thodol ("the Tibetan book vouchsafing liberation from the intermediate state between life and re-birth-which state men call death"); technical comments concerning the planning and programming of psychedelic sessions; and specific instructive texts to be read by the guide at various stages ("bardos") of the psychedelic experience.

\title{
a. First edition, first printing:
}

\author{
Psychedelic Prayers/ after the/ tao te ching/ by/ Timothy Leary/ POETS \\ PRESS/ Kerhonkson, New York
}

$9 \times 7$ in. [96] pp. Printed on textured paper.

[1] half-title; [2] blank; [3] title; [4] Cover drawing by Michael Bowen./ Psychedelic Monograph IV/ Copyright 1966 by Dr. Timothy Leary/ Library of Congress Catalog Card Number 66-23650.; [5] dedication (to Aurora and William Hitchcock ); [6] blank; [7-14] Foreword (dated: Kumaon Hills, Almora, 


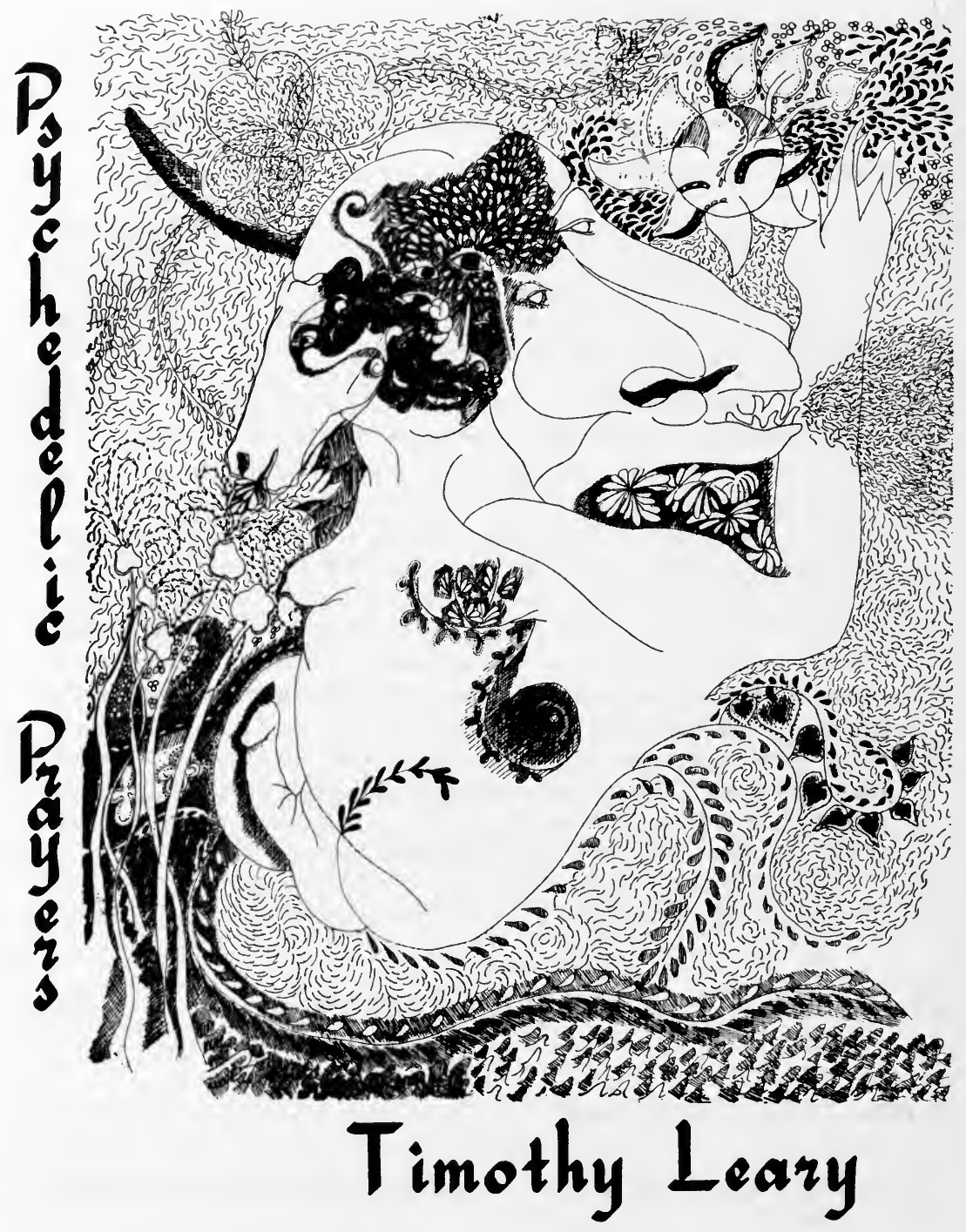

A5a: First printing of Leary's only work of poetry, written in India and published in Millbrook, N.Y., in 1966. Courtesy Citadel Press. 
India, 1965/ Millbrook, New York, 1966); [15-16] blank; [17-86] text; [87-88] blank; [89-92] Notes; [93-95] Index ; [96] blank.

Pink wrappers printed in black. Front cover: drawing by Michael Bowen in Hindu style; (along left edge:) Psychedelic Prayers; (along bottom edge:) Timothy Leary. Back cover: alchemical device; (below:) The Poets Press. Spine: PSYCHEDELIC PRAYERS. Timothy Leary/ Poets/ Press.

Published $1966 @ \$ 3.00 .2,500$ copies printed.

\section{b. First edition, second printing:}

Size and collation identical to A5a except text printed in color sequence of brown, orange, purple, blue and green. Paper partly laid and partly cross-hatched.

Cover identical to A5a except printed in red on mustard-colored paper wrappers.

Published $1966 @ \$ 3.00 .2,500$ copies printed.

\section{c. Second edition:}

Psychedelic Prayers/ after the/ tao te ching/ by/ Timothy Leary/ (single rule, thicker in middle) UNIVERSITY BOOKS (publisher's device) New Hyde Park, New York

$87 / 8 \times 6 \frac{1}{2}$ in. Photo-offset printing of A5a, with identical collation, but text printed in dark brown ink on untextured paper.

Binding identical to $\mathrm{A} 5 \mathrm{~b}$, but narrower, paper stock is textured rather than laid, Poets Press device on back cover but imprint deleted, and imprint on spine changed to: UNIVERSITY BOOKS (printed vertically).

Published Aug.1966@ @2.95. 5,000 copies printed. Copy seen with Citadel Press sticker on back cover, same price, presumably representing a later state.

\section{d. Third edition:}

Psychedelic Prayers/ after the/ Tao Te Ching/ by/ Timothy Leary/ (publisher's device: seal of the League)/(rule, thicker in middle)/ LEAGUE FOR SPIRITUAL DISCOVERY ** MILLBROOK, NEW YORK

$81 / 8 \times 67 / 16$ in. Photo-offset printing of A5c, with identical collation, but text printed in black on cream paper, and differs as follows: p.[4], top line now reads: Cover by Dion Wright; p. [5] Dedication changed to: The Brotherhood of Eternal Love, publisher's device added with seal of the League. 
Stiff, cream wrappers printed in black. Front cover: human figure showing nervous system, with a rose, directional lines and binary code in background; title and author's name printed at left and below in lettering similar to A5a. Back cover: Tibetan mandala. Spine: title and author's name printed as in A5a; no publisher's imprint.

Published ca. 1970 by the Mystic Arts Bookshop, Laguna Beach, Calif. Unknown number of copies printed and sold at various prices to raise money for Leary's legal expenses.

\section{e. Fourth edition:}

TAO TE CHING/ (publisher's device: seal of the League for Spiritual Discovery)/ PSYCHEDELIC PRAYERS (title engraved circularly on wooden box top)

$91 / 2 \times 7 \frac{1}{2}$ in. 49 unbound leaves.

[1-49] text, printed on one side only.

Sheets unbound, laid in wooden box. Title engraved on removable box top. Each leaf has decorative border, incorporating phrases "IN TAO WE TRUST" and "OM AMITABHA" with marijuana leaves, psilocybin mushrooms, peyote buttons, opium poppies, and Eastern religious symbols. Printed in purple on both sides of each leaf. Side without text of poem is stamped in purple with limitation letter and page number in sequence (copy in Fitz Hugh Ludlow Memorial Library has each leaf numbered B 27). Additional leaves are pasted inside top and bottom of box; the top leaf has a molecular design in center; the limitation number is written in ink.

100 copies of this edition were privately printed in Montreal by the publisher "Terra" in 1972. It was not intended for commercial sale. Each leaf is supposed to represent a separate piece of "script" (i.e., literary currency) which can be traded like a share of stock at a future date for profit.

Calligraphic lettering by Daniel Raphael. Issued in boxed form by the publishing arm of the League for Spiritual Discovery.

The author has considerably revised the text from previous editions listed above. Six poems are deleted (III-3, III-6, V-7, VI-12, VI-13, VI-14); three have changed titles (II-5, VI-16, VI-17) and many exhibit variations in text and setting ranging from slight to considerable. 


\section{f. First British Edition:}

PSYCHEDELIC PRAYERS/ AFTER THE/ TAO TE CHING/ BY/ TIMOTHY LEARY/ ACADEMY EDITIONS

$83 / 8 \times 5 \frac{1}{4}$ in. $96 \mathrm{pp}$.

[1-2] blank; [3] half-title; [4] reproduction of classical Chinese landscape painting; [5] title; [6] (5 lines of illustration credits, including original art and a poem by Peter Mayer)/ (dedication in one line surrounded by ornaments)/ (C) 1966 Timothy Leary/ Published by arrangement with Lyle Stuart-New York/ First published in Great Britain 1972/ by Academy Editions Holland Street London W8/ Printed in Great Britain by The Pitman Press, Bath/ ISBN 0902620525 paper; [7]-96 Foreword and text. Illustrations appear on pp. 4, 15, 24, 25, 56, 57 , $87,88,89$ and 94 .

Glossy orange and brown wrappers with horizontal stripes. Front cover prints short title and author. Back cover contains short blurb and price.

Published1972@£0.95. Unknown number of copies printed.

Leary's only book of poetry is a series of adaptations derived from nine English translations of the thirty-seven chapters constituting Book I of Lao Tse's Tao Te Ching or Way of Life, composed in the 6th century B.C. The work was produced in India in 1965 and finished in Millbrook, N.Y. the following year. In his lengthy introduction, the author describes being drawn to the "psychedelic" quality of the ancient work. "My objective," he later wrote, "was to find this seed idea in each sutra and rewrite it in the lingua franca of psychedelia" (Flashbacks). Six further adaptations from the Tao Te Ching, Book II, were published in East Village Other in 1969 (C58).

First edition:

Start/ your own/ (circular ornament)/ Religion/ By Timothy/ Leary $\mathrm{PhD} /$ (calligraphic lettering, decorative line border along left and bottom margins)

$91 / 16 \times 7$ in. (slight variations noted). [4] $30 \mathrm{pp}$.

[i] title; [ii] (photo: closeup of photo on p. [29])/ (C) League for Spiritual Discovery, 1967/ Published by the KRIYA PRESS of the SRI RAM ASHRAMA/ Millbrook, New York; [iii] description of the League for Spiritual Discovery, and 


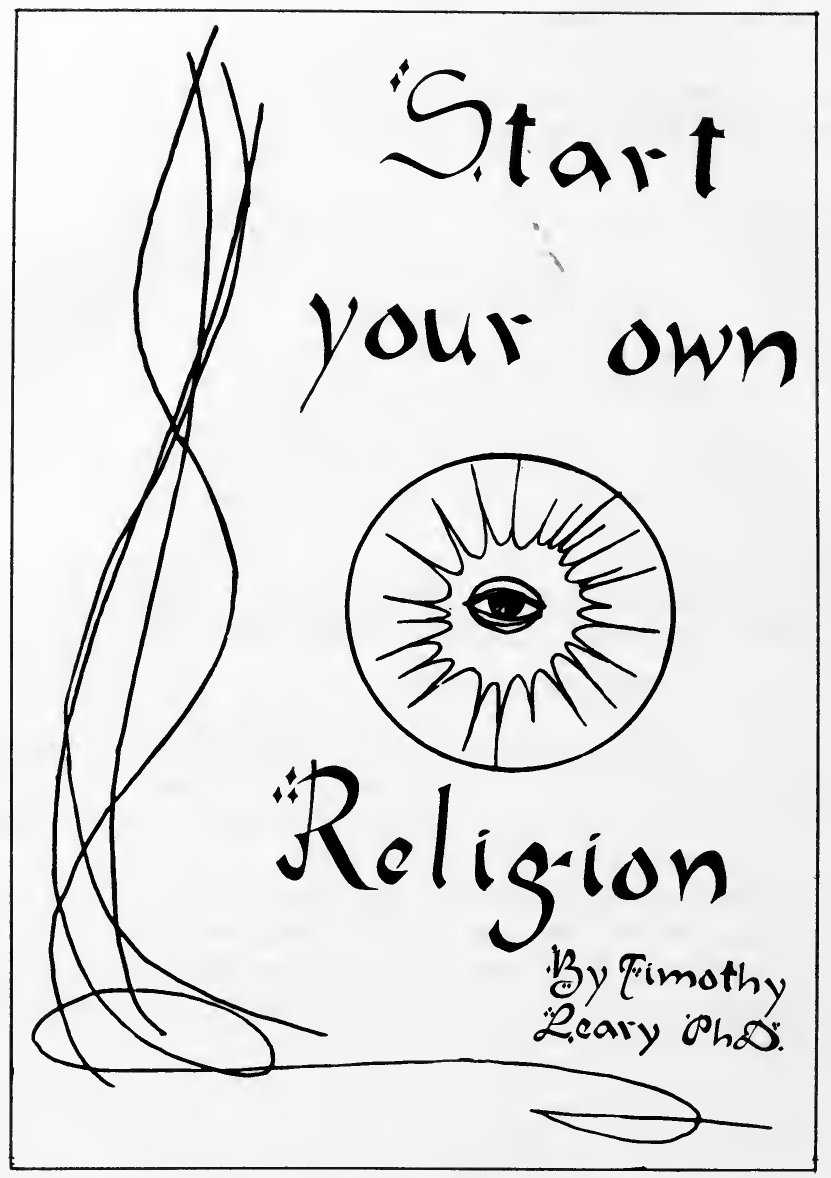

A6: A privately printed guidebook based on the practices of the League for Spiritual Discovery (1967). Courtesy Timothy Leary.

reproduction of its seal; [iv] full page photo of author; 1-16 text; [1-18] photographic insert; 17-27 text; [28] blank; [29] full-page photo of author; [30] photo acknowlegments.

Glossy, stiff, white wrappers, with psychedelic front cover design in orange, brown, yellow and red, incorporating text: Start/ Your Own/ Religion/ By/ Timothy Leary/ PH.D. Full-page photo of ornamental gate inside front cover. Back cover blank. Stapled.

Published 1967. Approximately 500-1,000 copies printed. Sold by mail order and through distribution to "head shops."

Portions of this text appeared in May 1967 in the Southern California Oracle, no. 1 (C48).

34 
"I wrote a small book, Start Your Own Religion, which outlined the legal, psychological, and spiritual steps involved in sacramentalizing one's life. . . . I hoped that this manual on how to use drugs intelligently would serve as a guide to those who would soon be experimenting with new realities. As usual we had troubles in distribution; most bookstores and chains wouldn't handle it" (Flashbacks). The photographs show activities at the Millbrook commune, including a wedding ceremony at which Leary officiated.

\section{a. First edition:}

HIGH/ PRIEST (printed vertically)/ by/ Timothy/ Leary/ (rule)/ Original art by Allen Atwell/ and Michael Green/ AN NAL BOOK/ The World Publishing Company/ New York Cleveland (photograph of author's face, right profile, occupies left two-thirds of double title-page, preceding text the right third)

$9 \times 6$ in. [xviii] 353 pp.

[i-ii] blank; [iii] half-title; [iv-v] title; [vi] (forty-six lines of copyright permissions)/ Copyright (C) 1968 by League for Spiritual Discovery, Inc./ All rights reserved./ (two lines pertaining to permission to reproduce)/ First Printing/ Published by The New American Library, Inc./ in association with The World Publishing Company/ 2231 West 110th Street, Cleveland, Ohio 44102/Library of Congress Catalog Card Number: 68-9031/ Printed in the United States of America.; [vii] dedication (to Susan and John Leary); [viii] blank; [ix] quotation from Dante's Divine Comedy; [x] blank; [xi-xii] Acknowledgments; [xiii-xiv] Chronology of Trips; [xv-xvi] Note (on the League for Spiritual Discovery); [16] blank; [xvii] fly-title; [xviii] blank; [1]-347 text; 349-53 Appendix; [354-58] blank. Apart from the photographic title page, there are 30 full-page illustrations within the text, consisting of reproductions of original psychedelic art by Allen Atwell and Michael Green, photographic reproductions (in several styles) of the author and of Allen Ginsberg, reproductions of some art masterworks.

Light gray boards with vertical dark gray and yellow lines, black cloth spine lettered vertically in gilt: HIGH PRIEST/ (single rule)/ Timothy Leary/ (publisher's device). H0195 stamped in gilt near bottom of back cover. Black endpapers. Dust jacket printed in black, white and yellow, with psychedelic sunburst design in pink, orange, purple, gray and yellow; with half-panel photograph of author by Fred W. McDarrah. Front and back panels reversed. Dust jacket design by Paul Bacon.

Published Mar. 25, $1968 @ \$ 7.95 .10,000$ copies printed. 


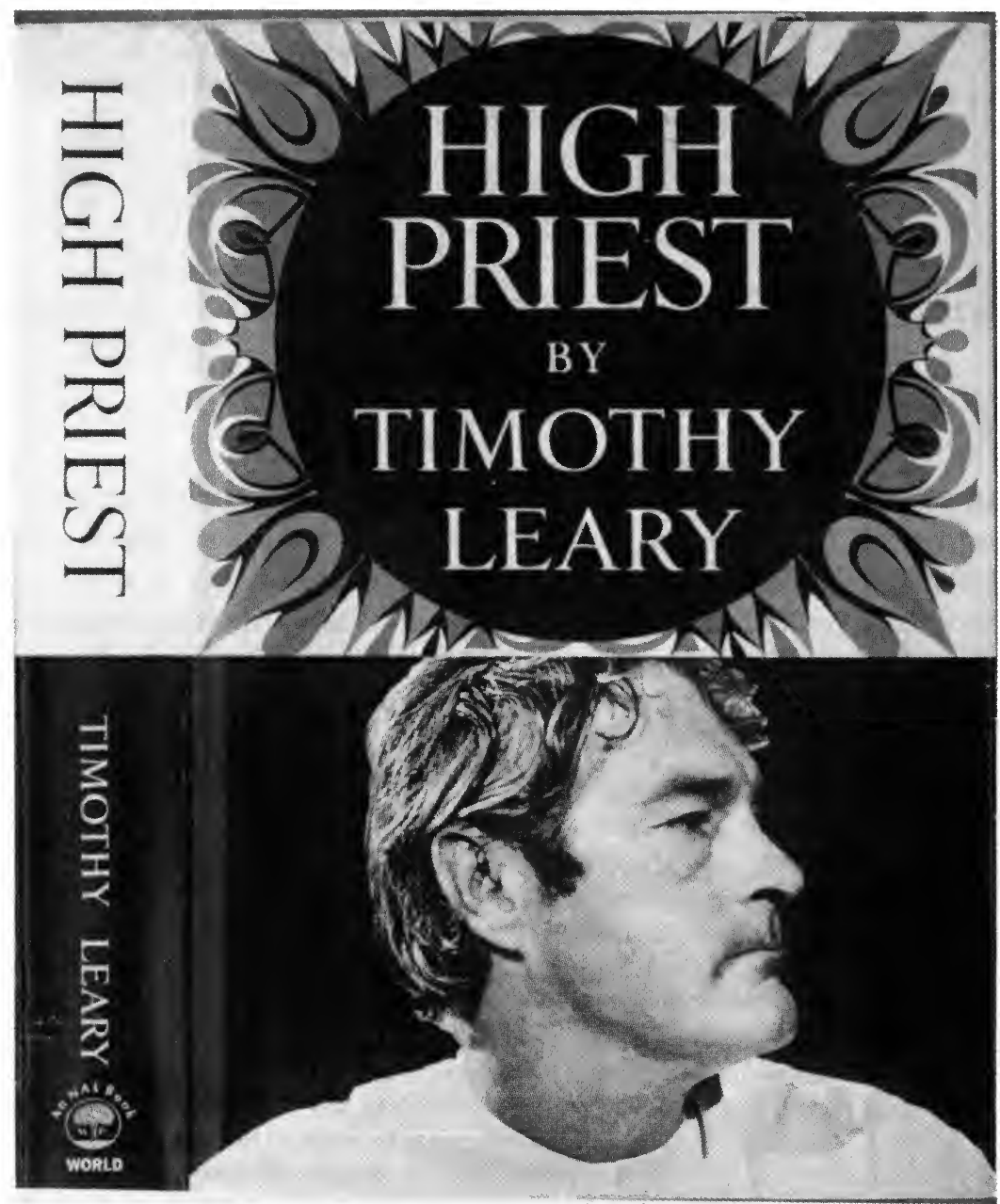

A7a: The first Leary book issued by a mainstream publishing house (1968). 
HIGH/PRIEST (printed vertically)/ by/ Timothy Leary/ (rule)/ Original art by Allen Atwell/ and Michael Green/ COLLEGE/ NOTES \& TEXTS, Inc./ NEW YORK, NEW YORK (photograph of author on double title-page and text arranged as in A7a)

$85 / 16 \times 5 \% 16$ in. [xiv] 354 pp.

Reduced photo-offset printing of A7a. Collation identical to A7a, except for following: no front blank leaf; half-title replaced by twenty-three line "Publisher's Note"; new title page; 354 is last page.

Stiff, orange and turquoise wrappers, printed in white. Front cover: publisher's name at top left; at top right: 7777-0/ $13 \mathrm{oz} .-\$ 2.95 / \mathrm{HIGH} / \mathrm{PRIEST/} \mathrm{BY/}$ TIMOTHY LEARY/ UNABRIDGED/ (psychedelic design of author's head by Michael Green). Back cover: publisher's name at left, blurb at right, design from front cover repeated. Spine: TIMOTHY/ LEARY/ (printed vertically:) HIGH PRIEST/ COLLEGE/ NOTES/ \&/ TEXTS.

Published Aug.1970@\$2.95.25,000 copies printed altogether of first issue and second issue (below).

c. First paperback edition, second issue:

Title identical to A7b.

$85 / 16 \times 5 \% 16$ in. [xiv] 354, $96 \mathrm{pp}$.

Collation identical to A7b except: on p. [iv] SECOND PRINTING replaces First Printing; there is at the end a ninety-six page appendix (A1-96) consisting of ten articles on the use and abuse of LSD and other psychedelic substances from medical journals and popular magazines.

Stiff, gold wrappers printed in white, black, blue, yellow, green and purple. Front cover: (at left:) COLLEGE/ NOTES \& TEXTS, INC./ MEDICAL DRUG EDUCATION/ (vertical:) PROGRAM (at right:) 7777-0/17 oz.-\$2.95/ HIGH/ PRIEST/ TIMOTHY LEARY/ UNABRIDGED (printed in ornate letters within elaborate mandalic frame along with the stylized design of author's head as used on cover of A7b, designed by Michael Green. Back cover: Chronology of Trips printed in black. Spine: lettering identical to A7b.

Published Nov.1970@\$2.95.

For details of publisher's poster issued for publicity of this edition, see L46. 


\section{High Priest/ Timothy Leary/ Magus Studios}

$11 \times 8 \frac{1}{2}$ in. [88] pp.

[1] title; [2] reproduction of p. [vi] of $\mathrm{A} 7 \mathrm{a}$, with the following added after the original copyright notice: published by magus studios/ p. o. box 8946/ salt lake city, utah/ 84108; [3-5] reproduction of pp. [vii] and [xi-xiv] of A7a; [6] list of author's works; [7] reproduction of p. [xv] of A7a; [8] blank; [9-88] reproduction of the text (except for appendix) of A7a.

Light gray paper wrappers, with two plastic back-strips. Front cover repeats title-page text with abstract illustrations of a school of dolphins. Back cover prints the opening paragraphs of the book, with one circular dolphin illustration repeated.

Type-reduced, double-column, photo-offset reprint of A7a.

Published Nov. 1984. 40 copies printed.

The author's "psychedelic autobiography," presented within the frame of sixteen inner "trips," the first caused by illness and despair, the following fifteen with LSD and psilocybin in the company of his son and daughter, Aldous Huxley, Allen Ginsberg, William Burroughs, Frank Barron, Richard Alpert, Ralph Metzner and others. The period covered is January 1959 to June 1962, when the author was lecturer in clinical psychology at Harvard University and director of the Psychedelic Research Project. High Priest is the first book of Leary's to be issued by a major trade publisher. At the time of publication the author had been for some years associated with the League for Spiritual Discovery; a note at the front describes the work as "the first of a four-volume biblical account of the birth, structural growth, exile, return, persecution, redemption, and flowering of the LSD religious cult."

High Priest is the first memoir written within the framework of a series of personal psychedelic drug experiences. The book is designed to display hexagrams and readings from the $I$ Ching, and a running marginal commentary on the text. A greatly altered version of the poetic section of Chapter 2 was reprinted in Circular Causation (C59a). A slightly abridged version of Chapter 9 was reprinted in Psychedelic Review, no. 10 (C64). A fragment of Chapter 16 was reprinted in The Hashish Club (BB14) under the title "LSD Is Air." 


\section{a. First edition:}

The Politics/ of Ecstasy/ by TIMOTHY LEARY/ (publisher's device at left); (at right:) G. P. Putnam's Sons/ NEW YORK

$85 / 16 \times 5 \% 8$ in. 371 pp.

[1] half-title; [2] blank; [3] title; [4] Copyright (C) 1965, 1966, 1967, 1968 by The League for Spiritual Discovery, Inc./ All rights reserved. This book, or parts thereof, must not be reproduced in any/ form without permission. Published simultaneously in the Dominion of Canada/ by Longmans Canada Limited, Toronto./ Chapter Seven originally appeared in Playboy magazine. Copyright (C) 1966 by/ HMH Publishing Co., Inc./ Library of Congress Catalog Number: 68-29674/ PRINTED IN THE UNITED STATES OF AMERICA; [5] dedication (to Rosemary Leary);[6] blank; [7] Foreword by Rosemary Leary; [8] blank; 9-[10] Contents; [11] fly-title; [12] blank; 13-371 text; [372-76] blank. Inserted between pp. 32 and 33 are 16 plates of psychedelic art printed on eight leaves of glossy paper: 4 by Bob Schnepf, 3 by Terrell P. Watson, and the others by an unknown artist.

White cloth with a few pink and green flower designs on the front cover. Spine lettered in green and pink: TIMOTHY/LEARY/ (printed vertically:) The Politics of Ecstasy/ Putnam. Upper and lower edges trimmed; fore-edge rough trimmed. Top edge stained pink. White endpapers with elaborate psychedelic drawing printed in pink (artist unidentified). Dust jacket glossy black with orange, pink and light green lettering (some incorporating floral motif) on front and spine; photograph of author and wife Rosemary at Laguna Beach on back cover. Dust jacket design by John Kashiwabara.

Published $1968 @ \$ 6.95$. 7,500 copies printed. (Size of print run estimated by author; publisher's records destroyed by flooding.)

\section{b. First American paperback edition, first issue:}

The Politics/ of Ecstasy/ by TIMOTHY LEARY/COLLEGE/NOTES \& TEXTS, Inc./ NEW YORK, NEW YORK

$85 / 16 \times 5 \% 16$ in. $371 \mathrm{pp}$.

Reduced photo-offset printing of A8a. Collation identical to A8a, except: [1] half-title is replaced by twenty-three line Publisher's Note; [3] new title imprint; the sixteen plates are printed on the same paper stock as the text, but these pages remain unnumbered. 


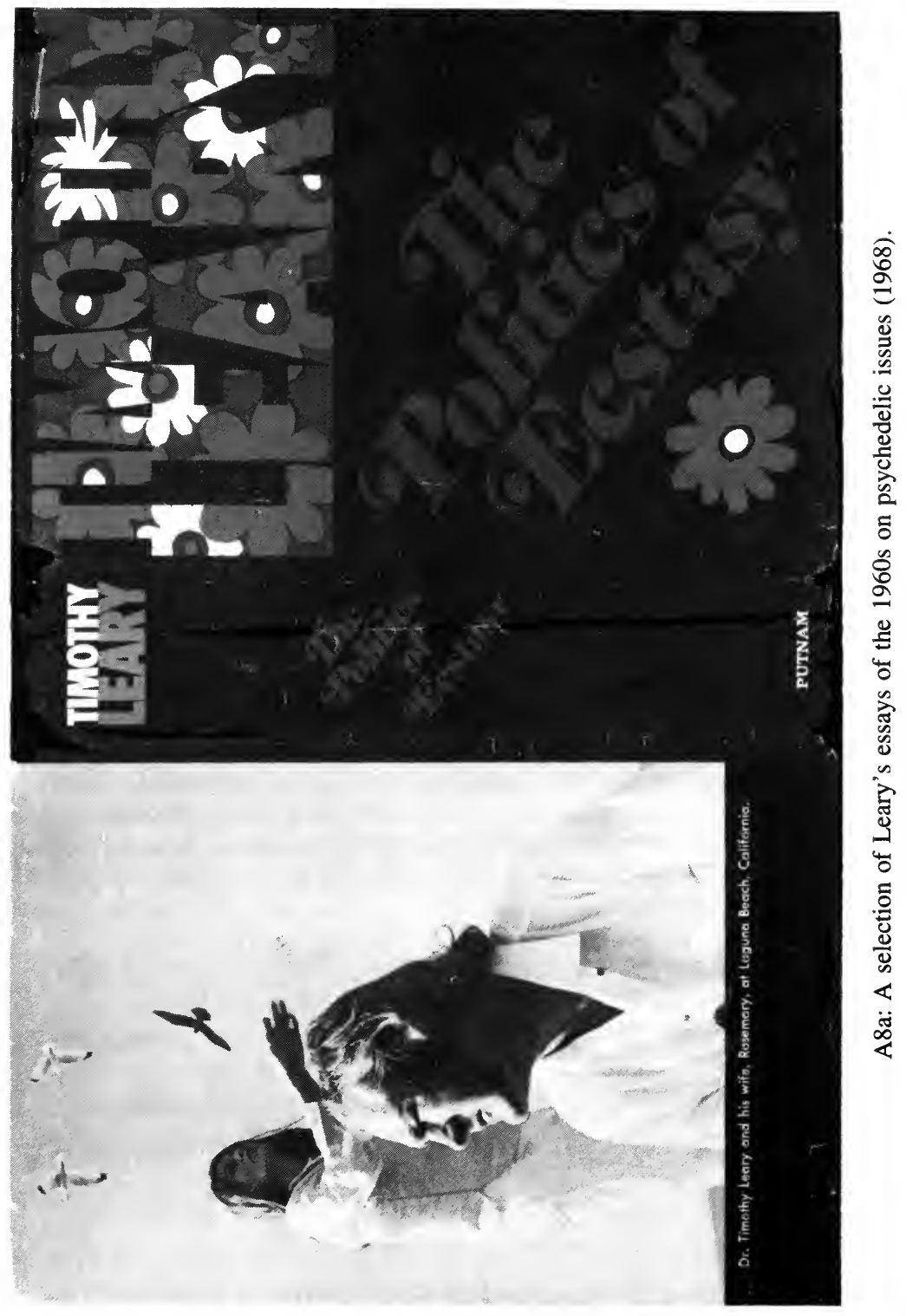


Stiff pink and green wrappers printed in white. Front cover: (at left:) COLLEGE/ NOTES \& TEXTS (at right:) 7780-2\#/13 oz.-\$2.95/ THE/ POLITICS/ OF/ ECSTASY/BY/ TIMOTHY LEARY/ UNABRIDGED/ (psychedelic design after inside plate by Bob Schnepf). Back cover: publisher's name, blurb and quotations from five reviews. Spine: TIMOTHY/ LEARY/ (printed vertically:) THE POLITICS OF ECSTASY/ COLLEGE/ NOTES/ \&/ TEXTS.

Published Oct.1971@ @2.95.10,000 copies printed altogether of this issue and the second issue (below).

c. First American paperback edition, second issue:

The Politics/ of Ecstasy/ by TIMOTHY LEARY/COLLEGE/ NOTES \& TEXTS, Inc./ NEW YORK, NEW YORK

$81 / 4 \times 55 / 16$ in. 371 pp.

Collation identical to $\mathrm{A} 8 \mathrm{~b}$.

Covers identical to A8b except the colors are orange and black printed in white, and price raised to $\$ 3.95$.

Published in early 1971.

d. Second American paperback edition:

The Politics of Ecstasy/ Timothy Leary/ Magus Studios

$11 \times 8 \frac{1}{2}$ in. [102] pp.

[1] title; [2] reproduction of pp. 9-[10] of A28a; [3] reproduction of p. [4] of A28a in revised format, with the following added at the end: published by magus studios/ p.o.box 8946/ salt lake city, utah/ 84108; [4-102] reproduction of the text of A28a.

Light gray paper wrappers, bound with two plastic strips. Front cover repeats lettering on title, with abstract design of planet and yin-yang symbols. Back cover repeats image and contains excerpt from text.

Type-reduced, double-column, photo-offset reprint of A8a.

Published Nov. 1984. 40 copies printed. 


\section{e. First British edition:}

Timothy Leary/ The/ Politics of Ecstasy/ MacGibbon \& Kee (publisher's device)

$73 / 4 \times 41 / 2$ in. 304 pp.

[1] (14-line biographical note on author); [2] blank; [3] title; [4] First published 1970 by MacGibbon \& Kee Ltd/ 3 Upper James Street Golden Square London W1/ Copyright (C) 1965, 1967, 1968 by The League for/ Spiritual Discovery, Inc./ (two lines pertaining to Chapter 7 copyright)/ (four lines pertaining to British printing)/ SBN 26163175 6; [5] dedication; [6] blank; [7] Contents; [8] blank; [9] Foreword; [10] blank; [11] fly-title; [12] blank; 13-304 text.

Lavender boards, spine lettered in silver: Timothy/ Leary/ (printed vertically:) THE POLITICS OF ECSTASY/ (publisher's device). Silver dust jacket printed in black, white, red, blue, yellow and green. Front cover: TIMOTHY LEARY/ THE/ POLITICS OF/ ECSTASY (printed in block letters above a psychedelic painting by Martin Sharp); back panel reproduces photo on back of A8a.

Published1970@36s. Size of printing unavailable. This is the first of Leary's books to be published in Great Britain. It was reprinted once in 1970 and once in 1971. The photographs were deleted.

\section{f. First British paperback edition:}

\section{Timothy Leary/ The Politics of Ecstasy/ Paladin}

$73 / 4 \times 47 / 16$ in. 301 pp.

Collates identically to A8e, except as follows: [2-3] title is set across two pages; [4] the first three lines read: Granada Publishing Ltd., 3 Upper James Street, London W1/ First published in Great Britain by MacGibbon \& Kee Ltd. 1970/ Published by Paladin 1970/ (the following (eight lines are identical except for addition of date 1966 in line four/ (followed by eleven lines setting forth conditions of sale and trade); [302-304] publisher's ads. Plates deleted as in A8e.

Stiff, silver wrappers, front reproducing design and colors of dust jacket of A8e except for change of the publisher's name and price. Back cover: blurb including quotation from Allen Ginsberg and Rosemary Leary. 
Published Apr. 9, $1970 @$ 50p. 72,000 copies printed. This edition was reprinted in 1970, 1971 (twice), 1972 and 1973. Publisher's records are incomplete, but show a printing of 15,000 on May 17, 1973, with price raised to $60 \mathrm{p}$.

Contains: "The Seven Tongues of God" (originally "The Religious Experience: Its Production and Interpretation"), AA43, reprinted in Psychedelic Review, C30, and Way Out, C31- "What to Do When the Vietcong Drops LSD in Our Water Supply," originally published in Bulletin of Atomic Science, C19_-"The Fifth Freedom-The Right to Get High," originally published as "The Politics of Consciousness Expansion" in Harvard Review, C22-“Ecstasy Attacked-Ecstasy Defended," originally published in abridged form in Esquire, C27- "Chemical Warfare-The Alcoholics, vs. the Psychedelics"—“"The Magical Mystery Trip," published simultaneously in Evergreen Review, C56-“She Comes in Colors," originally published in Playboy, D1_-"Drop Out or Cop Out"- "Hormonal Politics: The Menopausal Left-Right and the Seed Center"- "Poet of the Interior Journey," originally "Hermann Hesse: Poet of the Interior Journey," as published in Psychedelic Review, C24 - "A Trip with Paul Krassner," originally "An Interview with Timothy Leary," as published in The Realist, D2- “Start Your Own Religion," A6, sections 1-9-“American Education as an Addictive Process and Its Cure," a revision of a lecture given at the Second Annual Symposium on American Values at Central Washington State College in April 1963, AA40 - "Soul Session," originally "SOL Session with Timothy Leary" as published in SOL, D10_-"God's Secret Agent A.O.S.3" [Augustus Owsley Stanley III] - "M.I.T. is T.I.M. Spelled Backward," originally "An Interview-Timothy Leary, LSD, and Religion" appearing in Innisfree, D4 - "The Buddha as Drop-Out"- "Homage to Huxley," originally published in Psychedelic Review, C29- "The Mad Virgin of Psychedelia"- "Homage to the Awe-full See-er," originally published in Psychedelic Review, C52_-"The Molecular Revolution," transcript of a lecture originally delivered to the University of California LSD Conference, San Francisco, June 1966, see L26 - "Neurological Politics," later reprinted in book form as The Declaration of Evolution, A10; see C57 for simultaneous periodical printing.

Published in the same year as High Priest, The Politics of Ecstasy is a collection of the author's most significant essays and lectures on the psychedelic experience and the social and political ramifications of the psychedelic movement during the early and middle sixties. Much of the material appeared previously in magazines and journals; a few chapters appeared in print for the first time in this collection.

The American dust jacket blurb describes the author as "messiah, martyr, and high priest of the psychedelic," and describes the book as a "defense of ecstasy . . . documents of his own spiritual search." The English dust jacket blurb speaks of "this startlingly candid collection of essays in defence of ecstasy." 
First edition:

WANTED!! (bold lettering in style of 19th-century "Wanted" posters)/ By the State of California for three felonies and the State of New York for two/ felonies and various misdemeanors, crimes totalling 70 years' imprison-/ ment, and by the Federal Government for Pacifism in violation of the/ Selective Service Law./ (two photographs of Jack Leary, with captions)/ ALIAS: Buddha, Krishna, Son of Light, Silent Jack, Adam, Christ

$81 / 2 \times 5 \frac{1}{2}$ in. [8] pp. Leaflet printed on yellow paper; two sheets folded once. Copies examined neither stapled nor sewn; other copies may have been. Title printed at head of text, p. [1].

Published Sept. 1969. 300 copies privately printed and distributed free as fliers in Laguna Beach.

This anonymously written leaflet was privately printed by Leary to summarize and protest legal actions against his " 19 going on 77" year-old son, and by extension police actions against psychedelics-using and draft-evading youth throughout the country. Author states that the motivation for producing this leaflet was the fact that "Jack was not around for a court appearance in Laguna Beach and we feared a bench warrant would be issued for his arrest."

a. First edition in book form, first state:

THE DECLARATION OF EVOLUTION/ by Timothy Leary/ (publisher's device: seal of the League for Spiritual Discovery) (cover title)

$8 \frac{1}{2} \times 5 \frac{1}{2}$ in. [12] pp. Text printed from typescript.

[1] Mystic Arts/ Press/ dedicated to the brotherhood/ of Eternal Love; [2] blank; [3-11] text; [12] blank.

White wrappers; stapled. Front cover imprinted with title, as above. Back cover blank. Inside front cover carries the logo of the Holding Together Freedom Fund; the following is printed below: $\$ 300,000$ RANSOM NEEDED FOR THE RELEASE OF/ TIMOTHY LEARY/ KIDNAPPED BY GOVERNMENT 


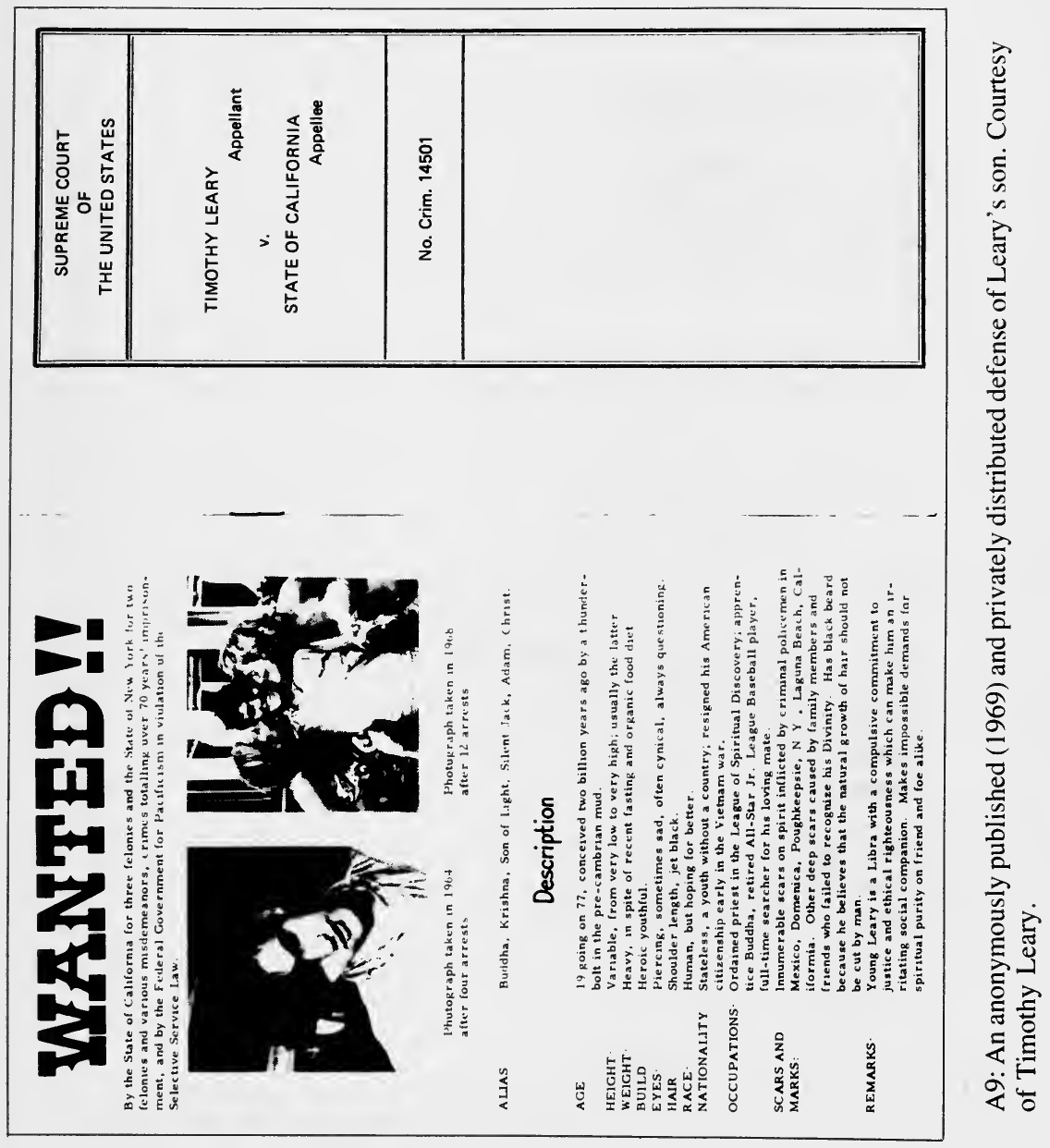


OFFICIALS/ HOLDING TOGETHER BRINGS GREAT GOOD FORTUNE/ Send to. . . . / (at left:) 1230 Queens Rd./ Berkeley/ California (at right:) Mystic Arts/ $670 \mathrm{~S}$. Coast Hwy/ Laguna Beach, Calif. Inside back wrapper is the publisher's device.

b. First edition in book form, second state:

Identical to A10a, except: p. [1] of text has the words "Mystic Arts Press" ornately hand-lettered and surrounding a stylized flame; replacing the Holding Together logo on the inside front cover is a drawing of a phoenix rising from flames above the hand-lettered words: Mystic Arts Fire Fund/ P. O. Box 704 Laguna Beach, Calif.

A reprint of pp. 362-68, and the italicized portion of p. 371, of The Politics of Ecstasy (A8). This printing of "The Declaration of Evolution" (originally printed under the title, "Neurological Politics") was made to raise money for Holding Together, a defense fund for Dr. Leary established after his imprisonment in Mar. 1970. Both states of the pamphlet were printed and published by the Mystic Arts Press, Laguna Beach in conjunction with Holding Together. The change on the inside cover of the second state refers to a fire which destroyed the Mystic Arts Bookshop.

Mystic Arts Press and Mystic Arts Bookshop were owned by The Brotherhood of Eternal Love, a loose-knit organization to whom Leary was linked in the 1973 investigation of the circumstances involving his 1970 prison escape. The BEL reputedly paid the Weather Underground to engineer Leary's escape from the profits they made from distributing a popular brand of LSD known as "Sunshine."

According to an unsigned, handwritten note by the printer of this edition, "several thousand copies" were printed, presumably in the spring of 1970. See C57 and C57a for earlier periodical publication.

\section{a. First edition, first printing:}

SUPREME COURT OF THE UNITED STATES/ (at left, enclosed at top and bottom by broken rule and at right by dotted rule:) TIMOTHY LEARY,I Appellant/ v./ STATE OF CALIFORNIA,/ Appellee (at right, enclosed by line rules at top and bottom) No. Crim. 14501/ MEMORANDUM OF THE APPELLANT/ TIMOTHY LEARY 
$715 / 16 \times 57 / 16$ in. [16] pp.

[1] title; [2] (C) 1970 Timothy Leary/ Published at the/ CITY LIGHTS BOOKSTORE/ 261 Columbus Avenue/ San Francisco, California 94133; [3] Introduction; [4] blank; [5-13] text; [14] blank; [15] Conclusion; [16] publisher's ads dated $1-70$ at bottom.

Blue paper wrappers printed in black; stapled. Front cover: (within double-rule, thick and thin, frame similar to that of legal brief) SUPREME COURT/ OF/ THE UNITED STATES/ (thick-thin rule)/ TIMOTHY LEARY/ Appellant/ v./ STATE OF CALIFORNIA/ Appellee/ (rule) No. Crim. 14501/ (rule). Back cover: (upper left) $\$ .50$ / This 'Eagle Brief' was prepared/ by Timothy Leary while in the/ California State Men's Colony-/ West at San Luis Obispo and is/ dated the date of his escape/ from that institution./ CITY (publisher's device) LIGHTS.

Published Sept. 30, $1970 @ \$ 0.50 .3,000$ copies printed.

\section{b. First edition, second printing:}

Collation and front cover identical to A1 1a. Back wrapper prints publisher's blurb in larger typeface and adds an additional paragraph and note on the printing as follows: An earlier version of it was published in the Berkeley Barb./ Second printing, March 1971.

Published Apr. 6, $1971 @ \$ 0.50 .3,000$ copies printed.

The self-described "Eagle Brief" was a legal appeal drafted solely by the author and filed by his attorneys in the U. S. Supreme Court. It was specifically addressed to Justice William O. Douglas. In it the author, comparing himself, his wife and two children to American eagles held in captivity, appealed for "bail pending appeal of his conviction" (a sentence of six months to ten years for possession of two half-smoked marijuana cigarettes found in the ashtray of a car he was driving on Christmas Eve, 1968) based upon "the principles of the First and Eighth Amendment and the sanctity of our tribal traditions." Several weeks after filing this brief and before any action was taken, the author escaped from prison (Sept. 12, 1970). He was seeking asylum in Algeria when this document was published in San Francisco. See C69 for first appearance in print.

\section{a. First edition:}

(printed in white on black:) TIMOTHY LEARY/ JAIL NOTES/ INTRODUCTION BY/ ALLEN GINSBERG/ A DOUGLAS BOOK/ Distributed by The World Publishing Company 


\section{TIMOTHY LEARY/JAIL NOTES}

\section{INTRODUCTION ALLEN GINSBERG}

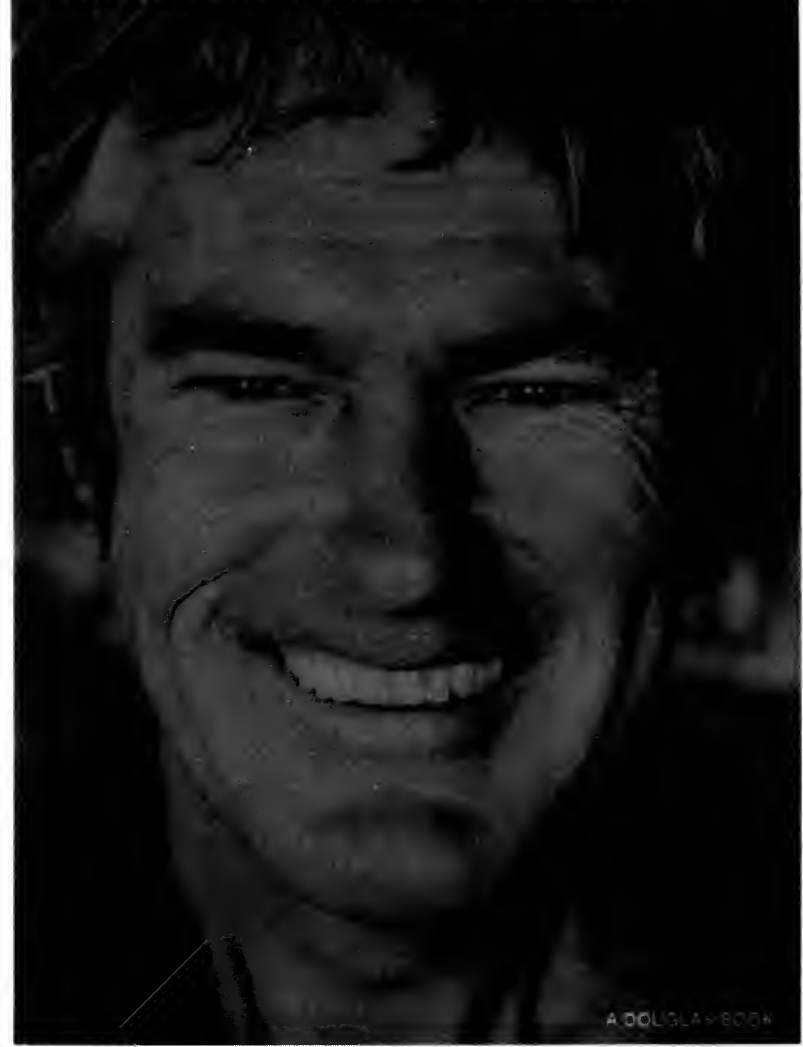

A12b: Leary's prison journal, smuggled out and published in 1970 shortly after his escape.

$81 / 8 \times 57 / 16$ in. $160 \mathrm{pp}$.

[1] half-title; [2] blank; [3] title; [4] Copyright (C) 1970 by Timothy Leary and the Douglas Book Corporation/ "Preface to Dr. Leary's Jail Notes" copyright (C) by Allen Ginsberg/ (four lines of copyright information)/ Library of Congress Cata$\log$ Card Number: 70-142526/ First Printing/ Manufactured in the United States of America/ DESIGNERS: BOB CATO AND IRA FRIEDLANDER/ The photograph on page 118 is by Victor Pilisoff. All other photographs/ acquired from the Timothy Leary Archives. Photographers' names unobtainable./ DOUGLAS BOOK CORPORATION/ 145 West 55th Street/ New York, New York 10019/ (twenty-eight lines of permissions); 5 Contents; [6]-15 Preface by Allen Ginsberg; 16-154 text; [155-60] blank. Five photographic illustrations in the text, on pp. $[6],[16],[118],[130],[150]$. 
Silver paper boards stamped vertically in dark blue on spine: TIMOTHY LEARY/ JAIL NOTES/ DOUGLAS (slashes are printed). Orange endpapers. Red, white and blue silk ribbon marker. Silver dust jacket printed in white and black. Front panel has photograph of author, overprinted with text in white. Back panel has photograph of author and wife Rosemary with a quotation from the book. Jacket spine reproduces spine of cover. Jacket flaps carry quotations from book.

Published Nov.1970@ @6.95. Approximately 2,500 copies printed.

\section{b. First (simultaneous) paperback edition:}

$81 / 4 \times 57 / 16$ in.

Collation identical to A12a.

Stiff, silver wrappers printed in white and black. Front cover: photograph of author (slightly larger, otherwise identical to front panel of dust jacket of A12a), overprinted in white: TIMOTHY LEARY/ (slash printed) JAIL NOTES/ INTRODUCTION ALLEN GINSBERG/ A DOUGLAS BOOK. Back cover: Publisher's blurb regarding author's escape from prison "on the morning of September 13, 1970 " followed by quotations from the text. Spine: identical to A12a, except smaller typeface used.

Published same day as hardcover edition @ $\$ 2.95$. Approximately 10,000 copies printed.

\section{c. Second American edition, first issue:}

TIMOTHY LEARY/ JAIL NOTES/ INTRODUCTION BY/ ALLEN GINSBERG/ GROVE PRESS, INC., NEW YORK

$7 \times 4 \frac{1}{8}$ in. [ii] $158 \mathrm{pp}$.

Reduced photo-offset reprint of A12a, to which it collates identically except as follows: [i-ii] blank; [4] (top seven lines identical to A12a)/ First Zebra Books Edition, 1972/ (remainder of page identical to A12a, except three lines giving original publisher's name and address deleted); only two blank pages at end.

Stiff, white wrappers printed in two shades of red, black and gray. Front cover: Z-1104-D (publisher's zebra device) \$1.50/ Timothy Leary/ Jail Notes/ with an introduction by Allen Ginsberg/(photograph of author occupying bottom two-thirds of cover). Back cover: Z-1104-D/ ZEBRA BOOKS (device, price) / quotation from Ginsberg's preface/ (rule)/ publisher's blurb/ (rule)/ Photo: United Press International Printed in U.S.A. Spine: (printed vertically:) JAIL NOTES BY TIMOTHY LEARY (horizontally:) (publisher's device)/ Z-1104/ ZEBRA BOOKS. Edges stained yellow.

Published $1972 @ \$ 1.50$. Unknown number of copies printed (publisher's records lost). 


\section{d. Second American edition, second issue:}

Collation identical to A12c, except for the following addition on p. [4] following line 7: ISBN: 0-394-17815-7/ First Evergreen Black Cat Edition, 1973/ Distributed by Random House, Inc. New York. (Note: reference to Zebra Books Edition deleted and typeface giving designers' names reduced; the words "First Printing" remain.)

Cover identical to A12c, except front cover, top line changed to: B-367 (publisher's cat device) \$1.50; back cover, top line changed to: B-367 AN EVERGREEN BLACK CAT BOOK/ (device, price); back cover, bottom right adds ISBN no.; spine imprint changed to: GROVE PRESS/ (device)/ B-367.

Published $1973 @ \$ 1.50$. Number of copies unknown (publisher's records lost).

\section{e. First British edition:}

\section{Timothy Leary/ Jail Notes/ INTRODUCTION BY/ Allen Ginsberg/ NEW ENGLISH LIBRARY/ TIMES MIRROR}

$7 \times 4 \frac{1}{4}$ in. 160 pp.

[1] half-title; [2] thirty-five lines of credits; [3] title; [4] (C) 1970 by Timothy Leary and the Douglas Book Corporation/ "Preface to Dr. Leary's Jail Notes"/ copyright (C) 1970 by Allen Ginsberg/ (asterisk)/ FIRST NEL PAPERBACK EDITION SEPTEMBER 1972/ (asterisk)/ five lines pertaining to conditions of sale/ NEL Books are published by/ New English Library Limited from Barnard's Inn, Holborn, London, E.C.1./ Made and printed in Great Britain by Hunt Bernard Printing Ltd, Aylesbury, Bucks./ 45001301 4; [5] Contents; [6]-15 Preface; [16]-160 text. No illustrations present.

Black stiff wrappers printed in white, blue, yellow and orange. Front cover: (enclosed within a frame of orange and blue, incorporating publisher's device at top) NEW ENGLISH LIBRARY UNDERGROUND CLASSIC/ JAIL NOTES/ (photo of author smiling behind prison bars)/ TIMOTHY LEARY/ "The personal story of the high-priest/ of the L.S.D. Generation"/ Introduction by Allen Ginsberg. Back cover: publisher's imprint, blurb and photo credit, prices in different British Commonwealth countries. Spine: publisher's device/ (printed vertically:) Jail Notes/ TIMOTHY LEARY/ 013014.

Published Sept.1972@ @0p. (Sticker on front cover indicates American price of $\$ 2.25$.) Undisclosed number of copies printed.

Jail Notes comprises four sections following Allen Ginsberg's preface: 1. Jail Notes (the author's prison diary from Feb. 25 to May 12, 1970); 2. Bodyguard (a prison incident); 3. The Four Thousand Year Old Rock and Roll Band: A Memory Experienced (an account of the author's visit to Morocco with his wife Rosemary in 1969); 4. Star Trip for Ro (the author's account of a psychedelic trip taken with his wife on a mountaintop in 1969). Ginsberg's preface describes the recent 
tradition of visionary consciousness in the United States from the 1920s to the Beat Generation and the Psychedelic Movement, with an emphasis on Leary's achievement as a "hero of American consciousness," and to legal problems stemming from his LSD experiments, writings, and public statements. The first section of Ginsberg's preface originally appeared in The Village Voice in 1968 (J149).

Jail Notes was first published about three or four months after the author's escape from prison. The British edition refers to him "now believed to be living in Switzerland."

a. Trial edition, first issue:

NEUROLOGIC/ These are the last words from the past./ Let us go free. . . . . into the future./ Joanna and Timothy/ (at lower right:) Transmitted by Joanna and Timothy

$11 \times 8 \frac{1}{2}$ in. [**] ii, 24 pp.

${ }^{[*]}$ title; [**] Contents; i-ii Introduction; 1-24 text.

Orange-yellow wrappers, stapled.

An unknown number of copies (probably fewer than fifty altogether of this issue and the second described below) reproduced from typescript were circulated in late Apr. and May 1973, in San Luis Obispo, Calif., where the author was incarcerated awaiting trial for his 1970 prison escape. Typed by Betsy Grace Klein; distributed by Joanna Leary.

b. Trial edition, second issue:

NEUROLOGIC/ These are the last words from the past./ Let us go free. . . . . into the future./ Joanna and Timothy/ NEUROLOGIC was written by Timothy Leary/ during March 1973, while in a "solitaire/ cell" in the administrative segregation/ unit of C.M.C. East, a California State/ Prison in San Luis Obispo. Timothy Leary/ is presently doing a 6 month to 10 year/ term for possession of "TWO ROACHES" of/ marijuana (one tenth of a GRAM and a 6/ month to 5 year consecutive term for his/ ESCAPE from prison in September 1970./ This is a total of maximum 15 years in a/ State Prison of California. This essay/ was inspired by Joanna Harcourt-Smith./ She is Timothy's partner in time. During/ May 
1973, Timothy Leary was transferred/ to Folsom, to complete his prison sentence./ Transmitted by Joanna and Timothy/ Printed May, 1973

Size and collation identical to A13a. Apart from extended wording of the title, there is one further textual variation, the addition of two words (PSI PHY) following end of first sentence on p. 1 .

Blue wrappers, the front wrapper bearing an oval photo reproduction of Joanna Harcourt-Smith sitting on the author's lap in the prison visiting room above the following: NEUROLOGIC/ TRANSMITTED BY JOANNA \& TIMOTHY. Stapled.

See A13a for details of publication.

c. First edition, first issue:

NEUROLOGIC/ Transmitted by Joanna and Timothy

$63 / 4 \times 47 / 8$ in. [44] pp.

[*] (red rubber-stamped:) This first edition is limted [sic] to/ 1000 numbered copies, signed/ by the publisher, of which this/ is No- (numbered and signed beneath by Joanna Leary); $[* *]$ blank; $[* * *]$ title; $[* * * *]$ These are the last words from the past./ Let us go free . . . into the future./ Joanna and Timothy; [*****] Contents; i-iii Introducti****I-1-I-4, II-1-II-2, III-1-III-2, IV-1-IV-6, V-1-V-3, VI-1-VI-4, VII-1-VII-13 text; [2] blank.

Stiff, white, semi-glossy wrappers. Front cover: Neurologic (printed in black cursive). Inside front cover: This book is another reason why Dr. Timothy Leary is incarcerated/ in solitary confinement since January 16, 1973 in a California prison./ Copyright (C) 1973 by Joanna Leary. Leaves stapled under flat spine.

Privately published in an edition of 1,000 copies by Joanna Leary in San Francisco in late 1973. This and subsequent issues and editions of Neurologic were produced by Level Press, their imprint appearing in the first typeset (i.e., third) edition. Text photo-offset from IBM Selectric typescript. Copies given away or sold for up to $\$ 10$ to raise money for the Leary defense.

\section{d. First edition, second issue:}

[Title not printed]/ Transmitted by Joanna and Timothy/ This version is a highly compressed galactic teletype/ designed for those with objective and subjective knowledge/ of the nervous system. A subsequent version is being/ prepared which will be comprehensible to the untutored/ and the inexperienced 


\section{TELROLOHIR}

\section{Transmitted by Joanna and Timothy}

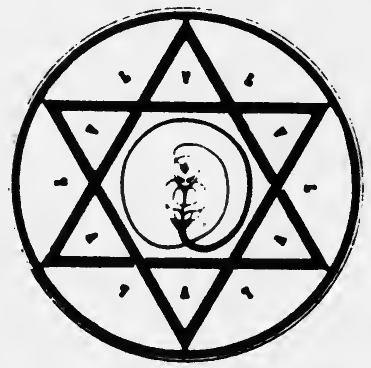

LEVEL PRESS

- SAN FRANCISCO •

A13j: First edition of Neurologic printed from type (1973).

$63 / 4 \times 47 / 8$ in. [44] pp.

Collation identical to A13c, except p. [*] is blank. The title is not printed on the title page.

Stiff, semi-glossy wrappers coated with gray halftone. Front cover: NEUROLOGIC (printed in tiny white dots). Inside front cover: This book is another reason why Dr. Timothy Leary/ is confined in a California state prison since January/ 18, 1973./ Copyright 1973 by Joanna Leary.

Approximately 500 copies printed and distributed by Joanna Leary in late 1973, and sold@\$3.00. 
(in computer-style type:) NEUROLOGIC/ Transmitted by Joanna and Timothy/ Copyright 1973 by Joanna Leary

$63 / 4 \times 47 / 8$ in. [44] pp.

$[*]$ half-title; $[* *]$ These are the last words from the past./ Let us go free . . . into the future./ Joanna and Timothy; $\left[{ }^{* * *}\right]$ title; $[* * * *]$ reproduction of a photograph of a painting by Dali-Ah; $[* * * * *]$ Contents; $[* * * * * *]$ blank; collation thereafter identical to $\mathrm{A} 13 \mathrm{c}$, except text begins on verso of leaf, leaving only one blank page at end.

Flat, white wrappers, printed in black. Front cover: (in computer-style type:) NEUROLOGIC/ (gap of $111 / 16$ in.) Transmitted by Joanna and Timothy. Back cover: This book is another reason why Dr. Timothy Leary/ is confined in a California state prison since January/ 18, 1973. Stapled.

This and subsequent variant states listed below were published by Joanna Leary in San Francisco in late 1973, in an unknown number of copies, and generally sold at $\$ 3.00$.

\section{f. Second edition, second state:}

Size and collation identical to A13e.

Blue wrappers, printed in black with same text and typeface as $\mathrm{A} 13 \mathrm{e}$. Inside front cover: (printed from typescript:) This version is a highly compressed/ galactic teletype designed for those/ woth [sic] objective and subjective knowledge/ of the nervous system. A subsequent/ version is being prepared which will/ be comprehensible to the untutored/ and the inexperienced. Inside back cover: (printed from typescript:) The illustration facing the title page is from a/ photograph taken by Jose Tamez of an oil painting by Dali-Ah.

\section{g. Second edition, third state:}

Size and collation identical to A13f.

Glossy, white wrappers, printed in black identically to A13f, except text inside front cover now printed from type, reset in five lines, with error ("woth") corrected. Stapled.

\section{h. Second edition, fourth state:}

$7 \times 5$ in. Collation identical to $\mathrm{A} 13 \mathrm{e}$, but illustration on title-verso now printed in blue. 
Mauve wrappers, printed in dark red with same text and typeface as A13e, except gap between title and authors' names on front wrapper measures $27 / 8$ in. Text inside front cover identical to that of $\mathrm{A} 13 \mathrm{~g}$, but illustration credit now deleted from inside back cover.

\section{i. Second edition, fifth state:}

$7 \times 5$ in. Collations identical to A13e, except illustration now printed in colors shading from blue to red.

Gray wrappers with fine weave, printed in dark red. Text and typeface same as A13e, except gap between title and authors' names on front cover measures $13 / 8$. Illustration credit inside back wrapper deleted.

\section{j. Third edition:}

(in computer-style type:) NEUROLOGIC/ Transmitted by Joanna and Timothy/ (publisher's device)/ LEVEL PRESS/ • SAN FRANCISCO •

$83 / 8 \times 5 \frac{1}{2}$ in. $64 \mathrm{pp}$.

[1] half-title; [2] blank; [3] title; [4] Copyright 1973 by Joanna Leary; [5] Contents; 6-9 Introduction; 10-64 text.

Black and white glossy wrappers, printed in black, red and blue. Front cover: (at left, in computer-style type:) NE/UR/OL/OG/IC/ Transmitted/ by Joanna/ and Timothy Leary (to right:) schematic diagram of DNA strand. Back cover: (printed vertically) This book is another reason why Dr./ Timothy Leary has been confined in a/ California prison since January 18,/ 1973 (to left:) front cover diagram repeated. Spine: NEUROLOGIC/ Joanna and Timothy Leary/ LEVEL PRESS.

About $500-1,000$ copies published in late 1973 . Generally sold at $\$ 3.00$. This is the first edition of Neurologic printed from type. See C81 and C89 where the complete text was published.

Neurologic is a short, highly condensed scientific essay describing the evolution and operation of the human nervous system in (seven) circuits, and the manner by which imprints are taken for each circuit. Neurologic was written in a maximum-security prison cell where the author was incarcerated between Feb. and Apr. 1973, following his capture in Afghanistan in January. "It was one of those inspired clear-channel transmissions. I had been thinking about the classification of brain circuits for years, and now in slow tidy handwriting, with almost no corrections, the words poured out" (Flashbacks).

Portions of the text entered the testimony during the course of the author's trial for escape in San Luis Obispo, Apr. 1973. The ideas first articulated in this essay were later developed in Exo-Psychology (A19) and The Game of Life (A23). 
a. First edition, advance issue:

Confessions/ of a/ Hope Fiend/ (thin rule)/ TIMOTHY LEARY/ (circularly surrounding publisher's device:) BANTAM BOOKS • NEW YORK • TORONTO $\bullet$ LONDON/ A NATIONAL GENERAL COMPANY

$7 \times 4 \frac{1}{8}$ in. $296 \mathrm{pp}$.

[i-iv] Editor's Note (dated April 1973); [v] title; [vi] CONFESSIONS OF A HOPE FIEND/ A Bantam Book/ (printed slash) July 1973/ All rights reserved./ Copyright $\mathbb{C} 1973$ by Michel-Gustave Hauchard./ (three lines about reproduction rights)/ Published simultaneously in the United States and Canada/ (thin rule)/ (five lines of trademark information)/ (thin rule)/ PRINTED IN THE UNITED STATES OF AMERICA; [1]-296 text; [297] publisher's ad; [298] blank.

White, semi-glossy wrappers printed in black. Front cover: (printed in white within black oval:) ADVANCE/ READING COPY/ NOT FOR SALE/ (printed in black:) Timothy/ Leary/ Confessions/ of a/ Hope Fiend/ (nine-line quotation from the Editor's Note/-MARC JAFFE, EDITORIAL DIRECTOR, BANTAM BOOKS/ (within box:) PUBLICATION: JULY 1, 1973/ PRICE: \$1.95/ A BANTAM PAPERBACK ORIGINAL. Back cover: (printed in white within black oval:) ADVANCE/ READING COPY/ NOT FOR SALE/ (printed in black:) Bantam Books, 666 Fifth Avenue, New York, N.Y. 10019. Spine: (publisher's device)/ a bantam/ original/ (printed vertically) Confessions of a Hope Fiend • Timothy Leary.

Published June 1973 for distribution to reviewers. Undisclosed number of copies printed.

b. First edition, regular issue:

Size and collation identical to A14a.

Glossy, black and gold wrappers, printed in gold and black. Front cover: (printed vertically at left:) Y8070 * \$1.95* A BANTAM BOOK (publisher's device)/ Timothy Leary/ (thin rule) Confessions/ of a/ Hope Fiend/ (photograph of the top of a burning candle). Inside front cover is a leaf printed in white and black on slightly thinner glossy red paper, the first five lines of which are readable through an oval cutout on the front cover: Now it can be/ told-the amazing/ story of one of/ the great escapes/ of all time!/ ( 18 further lines of publisher's blurb can be read when book is opened). Back cover: His trial began/ 2000 years ago with Socrates./ (photo of the author)/ Timothy Leary/ (rule)/ (8 lines of publisher's blurb about the author)/ (rule)/ Confessions of a Hope Fiend/ (rule) The impact of this book/ will 


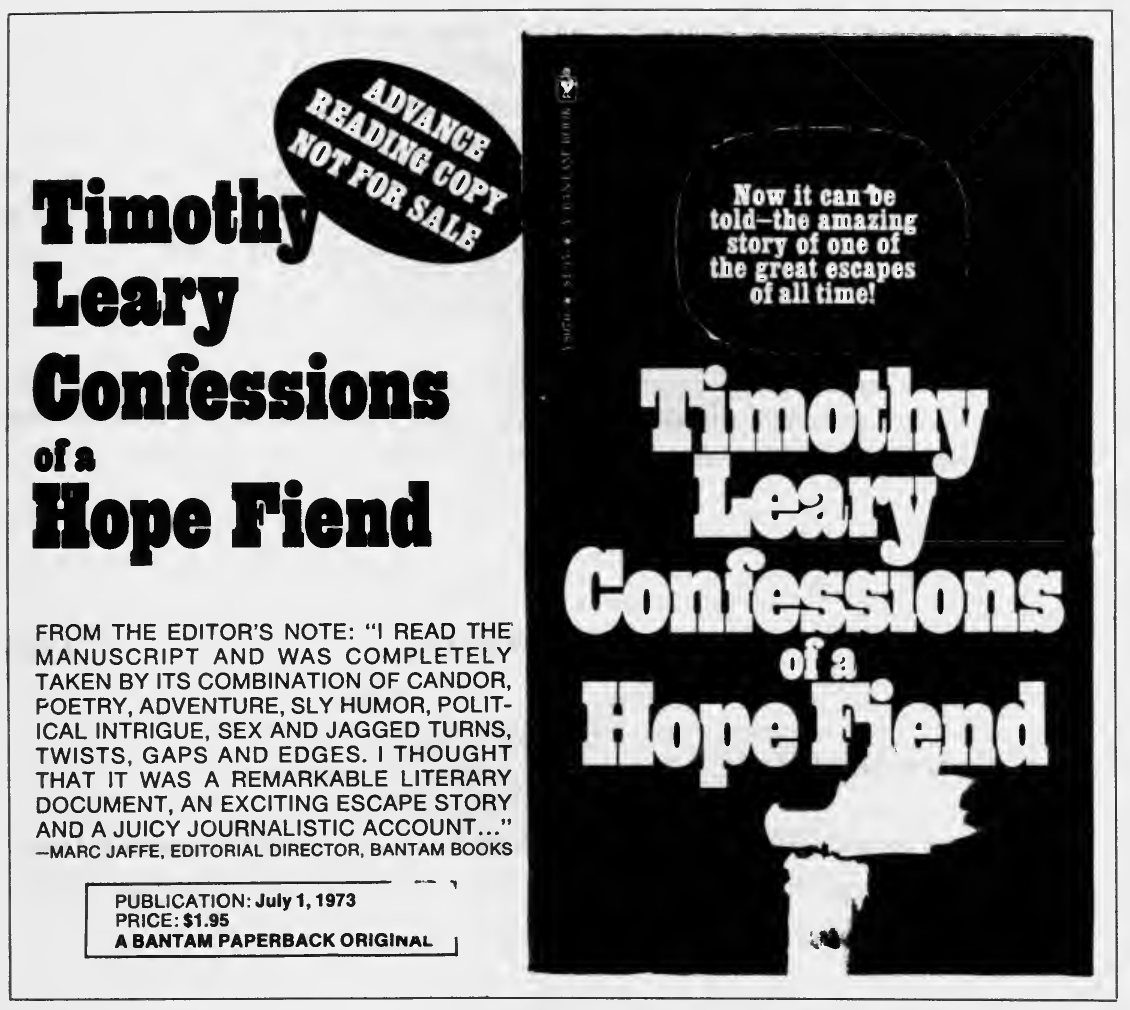

A14a-b: Advance (left) and regular trade printings of Leary's only mass-market book (1973).

be felt for years to come! Spine: (publisher's device)/ Bantam Books/ NON-/ FICTION/ (rule)/ \$1.95/ (printed vertically:) Confessions of a Hope Fiend • Timothy Leary/ 553/ 08070/ 195.

Published July 1, $1973 @ \$ 1.95 .25,000$ copies printed. Copies were available in the United Kingdom from the British office of Bantam Books@ @ $£ .50$.

Confessions of a Hope Fiend is the author's first mass-market paperback edition. It is an account of his experiences in prison from the time of his conviction for marijuana possession in Feb. 1970; his prison escape in Sept. 1970 with the aid of the Weather Underground; his flight from the United States with his wife, Rosemary; the period of his exile with the Black Panther party in Algeria; and his arrival in Switzerland in May 1972, where he would seek political asylum. 
The book was rewritten at least a dozen times (partly to protect people who aided him in his escape) during his Swiss exile. The text is dated at the end: July 7, 1972/ Zurich. Lengthy and delicate negotiations were required to contract the book (the story is outlined in the editor's note at the front), the author eventually receiving an advance of $\$ 250,000$, half of which (along with the copyright to the book) went to his French-Swiss "protector" Michel Hauchard, most of the rest being divided among various attorneys, agents, and a writer-friend (Brian Barritt) who made important contributions to the project.

Some versions of the manuscript of Confessions of a Hope Fiend were seized with Leary's archives by the FBI in 1975 and used by them in attempt to determine the identities of those aiding his 1970 prison escape.

A15

STARSEED

a. First edition, first issue:

(first six words in ornate block letters:) STARSEED/ Transmitted from/ Folsom Prison by/ Dr. Timothy Leary/ (publisher's device)/ LEVEL PRESS/ • SAN FRANCISCO •

$7 \times 5 \frac{3}{8}$ in. 24 pp., printed on textured paper in colors shading from orange to purple.

[1] half-title; [2] blank; [3] title; [4] (11-line quotation and five-line credit from a press release of the Hayden Planetarium)/ (C) 1973 by Joanna Leary. All rights reserved/ Published for Joanna Leary by Level Press/San Francisco/ Cover design by Tim Leary \& Dana Reemes; 5-[24] text (small square centered at foot of p. [24]).

Mustard paper wrappers, printed in black with fanciful design of Comet Kohoutek with two nucleotide templates, across both covers. On the front cover below the drawing appears the title and author's name in the same style as on the title.

Inserted (probably not in all copies) is a printed slip about the Starseed Information Center in Santa Cruz (i.e., San Francisco) managed by the book's publisher, Joanna Leary.

Published Sept. 1973. Probably no more than several hundred copies of this issue were printed. This and subsequent issues generally sold for $\$ 2.00$. 


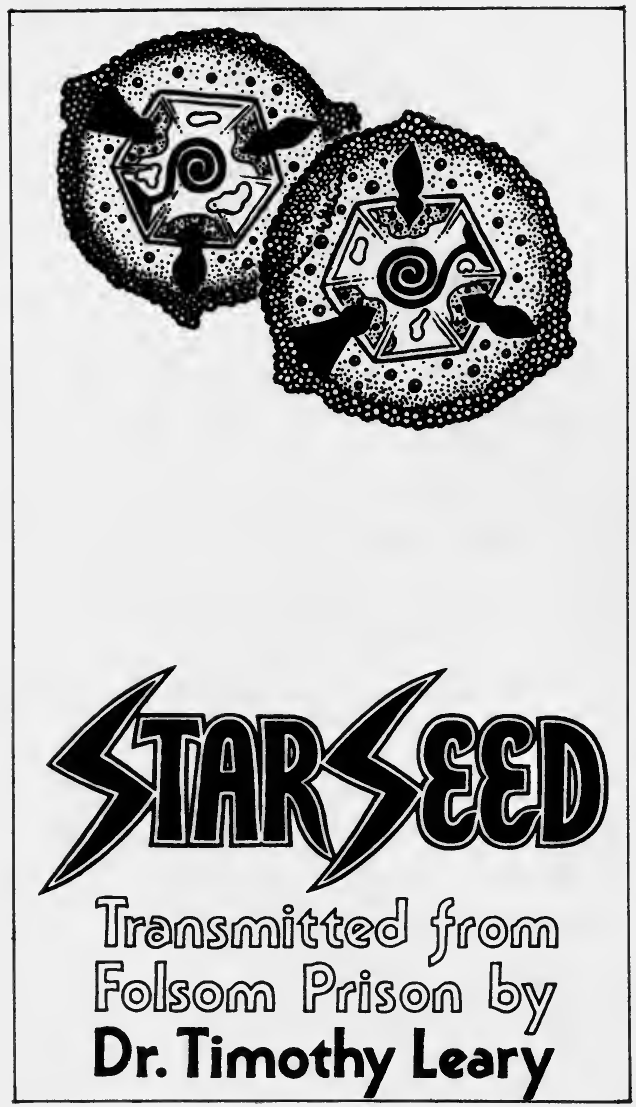

A15a: First published edition (1973) of Leary's reflections on the appearance of a comet in 1973.

\section{b. First edition, second issue:}

Title identical to A15a.

$7 \times 5$ in. (overlapping wrappers measure $7 \times 5 \frac{1}{2}$ in.). 24 pp., printed on same paper with similar color shading as A15a.

Collation identical to A15a, except for the following: [1] half-title changed to: STARSEED/ A PSI PHY COMET TALE; [2] has a frontispiece illustration of a photograph by Jose Tamez of an oil painting by Dali-Ah (identical to that in later issues of Neurologic); [4] has an illustration credit in three lines added after the eleven-line quotation. 
Mauve wrappers, printed in orange with identical cover design and text as A15a.

Published Sept. i973. Probably no more than several hundred copies of this issue were printed.

Note: All subsequent issues described below add the subtitle on the half-title.

\section{c. First edition, third issue:}

Five variants of this issue have been examined, collating identically to A15b, but printed on ordinary paper, with the variations limited to size, binding and color printing.

Variant 1. 67/8 $\times 415 / 16$ in. Text and frontispiece printed in colors shading from orange to purple. White, glossy wrappers, cover design in orange.

Variant 2. $613 / 16 \times 45 / 8$ in. Text printed in blue, frontispiece in red shading to orange. White glossy wrappers, cover design in black.

Variant 3. Identical to var. 3, except wrappers are gray with fine weave, printed in black.

Variant $4.7 \times 5$ in. (wrappers measure $71 / 2 \times 51 / 2$ in.). Text printed in purple and blue, frontispiece printed in red shading to blue. White, glossy wrappers, design printed in purple.

Variant 5. Identical to var. 4, but cover printing is blue.

All variants published in Sept. and Oct. 1973, generally selling @ \$1.75. Unknown number of copies printed, probably totaling about 1,000.

d. First edition: fourth issue:

Collates identically to A15b, except frontispiece deleted. Printed in black on blue or buff wrappers. Measures $63 / 4 \times 43 / 4$ in.

\section{e. Second edition:}

\section{Starseed}

$83 / 8 \times 5 \frac{1}{2}$ in. $20 \mathrm{pp}$.

[1] title; [2] STARSEED/COVER DESING [sic] BY WALKING HORSE/(rule)/ (six lines of cover credits)/ EARTHCREW OF MENTAL PRESS:/ (left column:) JOHNATHAN [sic]/ DAVID/ SANDRA/ GARY/ (right column:) MARK/ CHRIS/ TERRY; 3-20 text (small black star centered at foot of p. 20). 




A15e: Rare European edition (1974?) of the "Starseed Transmission." 
Paper wrappers printed in black, white and gray. Front cover: photographic image of a 2nd century B.C. jade mandarin of the Han Dynasty, title in decorative lettering to left/ (below: TRANSMITTED FROM/ FOLSOM PRISON BY/ Dr. Timothy Leary. Back cover: drawing of Hopi symbol of emergence. Stapled.

Privately printed by "Walking Horse" in a very small edition, probably in Switzerland or Nepal, ca. 1973-74.

Starseed is an essay of cosmological considerations prompted by the expected arrival of Comet Kohoutek in Dec. 1973. It was written a few months after Leary arrived at Folsom Prison to begin serving the rest of his sentence, including five additional years for escape. See C84 for simultaneous periodical publication.

First edition:

TERRA II/ THE STARSEED TRANSMISSION/ TRANSMITTED BY/ TIMOTHY LEARY/ LYNN WAYNE BENNER/ JOANNA LEARY/ GUANINE (row of periods connecting authors' names in a crisscross pattern)

$75 / 8 \times 51 / 2$ in. [16] XII [2] $178 \mathrm{pp.}$

[1] title; [2] reproduction of the "Starseed Transmission" in binary code on a hexagonal "chip"; [3] circular design printed in green, blue and yellow, with caption: TRADE MARK [sic] DESIGN: STARSEED, INC.; [4] Japanese text of the "Starseed Transmission" in English transliteration; [5] text of "Starseed Transmission" in English; [6] PUBLISHED BY IMPRINTING PRESS-SAN FRANCISCO, CALIFORNIA/ (rule)/ ALL RIGHTS RESERVED BY STARSEED, 531 PACIFIC STREET, SAN FRANCISCO,/ CALIFORNIA 94133/ (rule)/ COPYRIGHT C 1974 BY STARSEED, A PARTNERSHIP; [7] Acknowledgments in 17 lines, followed by limitation notice:) THIS FIRST EDITION IS LIMITED TO ONE THOUSAND/ NUMBERED COPIES, SIGNED BY THE PUBLISHER, OF/ WHICH THIS IS NUMBER-; [8] (8 lines of text pertaining to "the message of the comet"); [9] photo reproduction; [10] (4-line Japanese epigraph translated into English); [11-15] table of contents; [16] blank; I-XII STARSEED-A PSI-PHY COMET TALE [reprint of A15, but substantially revised]; [XIII] "extra-terrestrial" representation of numbers 1-6; [XIV] illustration of Starseed astronaut; 1-177 text, with unnumbered pages bearing illustrations following pp. 20, 33, 54, 91 (3 unnumbered pp.), 104 and 145; [178] GRACE COMPANY/ 22111 th STREET/ SAN FRANCISCO, CA/ 94103/ (415) 626-5433/ PRINTED JANUARY 13, 1974. Illustrations by Harold Olson (black and white pen-and-ink drawings) on pp. [xiv], 2, 12, 18, 21, 25, 29, $34,38,44,52,55,65,71,83,[91 b-c], 92,105,125,131,146$ and 172; photographic illustrations on pp. 11, 20a, 33a, 37, 54a, 79, 88, 91a, 104a, 145a and 166. 


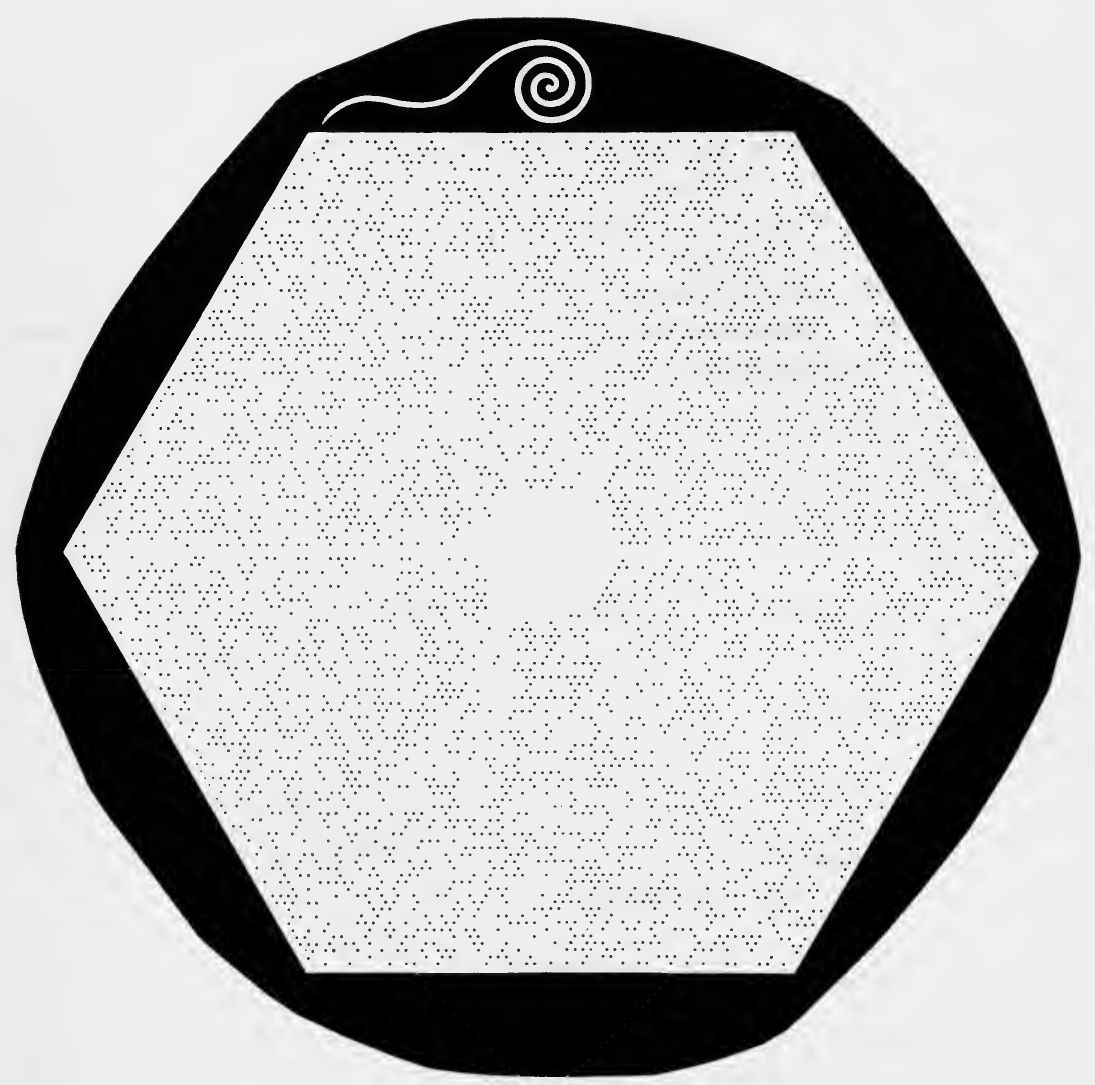

A 16: The "Starseed Transmission" in binary code printed in Terra II (1974), a manual for space colonization written in Folsom prison. It was also printed on a silicon disk (E2).

Stiff, semi-glossy wrappers. Front and back cover bear identical hexagonal image printed in gold with "Starseed Transmission." This is a photographic enlargement of the micro-silicon disk described in D2. Spine (printed vertically in gold:) TERRA II . . A A WAY OUT T. LEARY. Inside front and back cover is a double-page drawing by Harold Olson of space colony Terra II, with the central portion hidden under spine.

Published January 13,1974@ @ \$10.00. Approximately 800-900 copies printed (not 1,000 as stated). A small number of photocopies in double-page format, spiral-bound wrappers, $81 / 2 \times 11$ in., were produced and distributed by The Network in San Francisco, $1980 @ \$ 9.00$. 
Terra II was produced in Folsom Prison in the fall of 1973 by Leary and co-prisoner Benner, with the illustrations done by another prisoner, Harold Olson. The subject of the work is the evolution/migration from Terra I (Planet Earth) to Terra II (an orbiting space colony between Earth and the Moon). Joanna Leary, publisher of the book, and a Sacramento newspaper woman reporter using the pseudonym Guanine, are credited with co-authorship. Like the monographs Neurologic and Starseed, the proceeds of the sale of Terra II were intended to help pay expenses of costly legal appeals by Leary to win his freedom from prison. "Terra II . . . defined migration from the planet as the goal of our species. To me this was the ultimate escape plot" (Flashbacks).

In some copies of the book there was inserted as a promotional bookmark a "Ticket to Ride . . ." (see L56). Prepublication excerpts appeared in The Real Paper, C85. A postpublication abridgment appeared in High Times, C90.

First edition:

(in gothic script:) The Curse/ of the/ Oval Room/ (rule)/ TIMOTHY LEARY/Introduction by DICK GREGORY/ Illustrations by YOSSARIAN/ HIGH TIMES PRESS, NEW YORK

$81 \frac{1}{2} \times 5 \frac{1}{2}$ in. [4] iv, $32 \mathrm{pp}$.

[1] title; [2] blank; [3] Copyright (C) 1974 by Joanna Leary./ (two lines pertaining to reproduction rights)/ High Times Press/ Box 386, Cooper Station/ New York, N.Y. 10003/ Printed in the United States of America/ First Printing; [4] blank; i-iii Introduction; [iv] illustration; 1-31 text; [32] blank. Full-page illustrations appear on pp. [iv], [2], [4], [8], [12], [16], [18], [22], [24] and [28]. Pp. [7], [15] and [27] in the text are blank.

Red and white glossy wrappers. Front cover printed in black: $\$ 2.00$ / (in gothic script:) The Curse of the Oval Room/ (illustration from p. 22 repeated within oval frame)/ Transmitted by/ TIMOTHY LEARY/ Illustrated by/ YOSSARIAN.

Published $1974 @ \$ 2.00$. Undisclosed number of copies printed.

Written in Folsom Prison while the Watergate scandal was breaking, the author discusses various issues of "neurological politics," including Watergate mastermind G. Gordon Liddy spying on the Millbrook commune in 1966, the CIA and "bugging," secrecy and the electronic media, and the "curse" of the presidential oval office. "Yossarian" is the pseudonym of the underground cartoonist Donald Schenker.

This work was the initial publication of High Times Press, the short-lived publishing arm of High Times magazine. Chapters 2 to 5 appeared in Ramparts in revised form (C87). 
First edition:

(printed in four different typefaces and partially enclosed within a single- or double-rule border:) Part V/ WHAT DOES WOMAN WANT?/ (ADVENTURES ALONG THE SCHWARTZCHILD RADIUS)/ By/ TIMOTHY LEARY/ (The characters described in this book are entirely coincidental.)/ 88 Books

$10^{13 / 16} \times 8^{1 / 2}$ in. [xviii] $240 \mathrm{pp}$.

[i-ii] blank; [iii] This is a Limited First Edition/ of five thousand numbered copies,/ of which this is Number_/ (publisher's device); [iv-ix] (printed in various typefaces:) . . . WHAT DOES WOMAN WANT? . . . A SCIENCE FACTION . . STARRING . . TIMOTHY LERI [sic] as VULCAN-8 . . . ROSEMARY BARNACLE as DEMETER-3 . . MICHEL HAUCHARD as HERMES-4 . . MONSIEUR DUVAL as APOLLO-6 . . ARYABHATA as NEPTUNE-14 . . . Flora Lu as Psyche-20 . . A AND INTRODUCING . . . joanna harcourt-smith tamacopoulos de layne y ulam!!!! as juno II . . . ; [x] Copyright (C) 1976 by Timothy Leri and 88 Books/ (three lines pertaining to reservation of rights)/ Published by 88 Books/ 9350 Wilshire Boulevard/ Beverly Hills, California/ Cover drawing by John Eastman/ Graphics by Yuki Sakata and Joanna Leri/ Manufactured in the United States of America/ By KNI, Anaheim, California/ Typesetting and Layout $-/$ Conscious Communications/ 5274 West Pico Boulevard/Los Angeles, California/ 123456789 10/ (eleven lines of acknowledgments); [xi] title; [xii] blank; [xiii] dedication (to joanna and chrysalis); [xiv-xvii] (author's partly illustrated description of "stage 13" of the "Fifth Circuit" of the nervous system) [xviii] Preface by Robert Anton Wilson; 1-2 Introduction; 3-237 text in 80 chapters, ending: TO BE CONTINUED; [238] blank; [239] Announcement of author's current works in progress followed by publisher's imprint: 88 Books/ P. O. Box 47/ Dexter, Oregon 97431; [240] blank

Limp, glossy, white wrappers, printed in black and orange. Front cover: (in computer type:) WHAT DOES/ WOMAN WANT?/ (multidimensional drawing of woman's head in profile)/ (in computer type:) timothy leary. Back cover: four blurbs (the first three written by the author under other names, the last by Robert Anton Wilson.) Spine: (in computer type:) 88/ (printed vertically:) what does woman want? TIMOTHY/ LEARY.

Published $1976 @ \$ 6.95$. 5,000 copies printed.

Note: Some copies of the first edition have an erratum slip imprinted PROMETHEUS pasted over VULCAN-8 on p. [iv]; some other copies have this correction made by hand in ink. The earliest copies distributed are probably those without any correction, followed in sequence by copies handprinted and copies with the errata slip. However, of four copies examined, this sequence is not born 


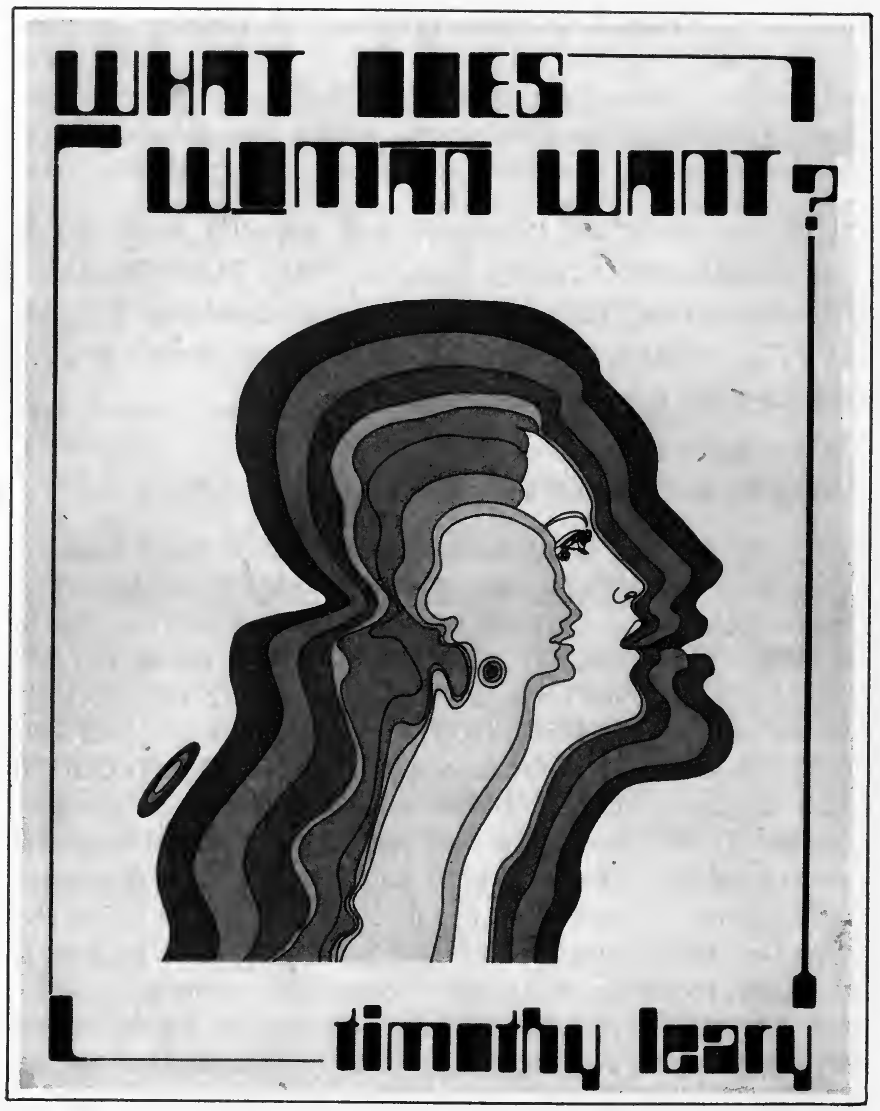

A18: Leary's only novel (1976), another in a series of books he wrote in prison or as a fugitive between 1970 and 1976 . Courtesy Timothy Leary.

out (copy no. 530 and 561 bear the correction in ink; copies 1285 and 3017 have the errata slip, and two late-numbered copies, 4530 and 4587, are uncorrected).

What Does WoMan Want? (the title is a paraphrase of a famous question posed by Freud; the capital " $M$ " is Leary's intentional spelling) uses the form of a science-fiction novel to deal with the period of Leary's exile in Switzerland, 1971-72, with flashbacks to earlier periods; the perspective is that of the distant future. This is the first of what the author refers to as his "Future History Series"; it was written during Leary's incarceration at the Federal Detention Center in San Diego in 1975, and published upon his release from prison in Apr. 1976. 88 Books was owned and operated by Joanna Leary.

A selection from this book was reprinted in Wings I, no. 1 (Sept./Oct. 1978). 
a. First edition, first printing:

EXO-PSYCHOLOGY/ A MANUAL ON THE USE OF THE HUMAN/ NERVOUS SYSTEM ACCORDING TO THE/ INSTRUCTIONS OF THE MANUFACTURERS/ TIMOTHY LEARY/ A STARSEED/ PEACE PRESS PUBLICATION • $1977 \bullet$ LOS ANGELES, CALIFORNIA

$10 \times 7$ in. [xvi] $136 \mathrm{pp}$.

[i] half-title; [ii] Books and Monographs by the Author/ (twenty-four lines of titles); [iii] title; [iv] Copyright (C) 1977 by Timothy Leary/ All Rights Reserved/ (rule)/ Published Jointly in the United States by/ Starseed/ Peace Press Inc./ P.O. Box 188/ Culver City, California 90230/ Manufactured in the United States/ Printed by Peace Press Inc./ (rule)/ (eight lines of LC catalog data giving LC no. 76-56056)/ ISBN 0-915238-16-0/ Coordinated by Jay Levey/ Designed and Illustrated by Cynthia Marsh for Starseed/ Typeset by/ Caravan Composing \& Design/ Los Angeles, California/ Layout by Linda Norlen/ Cover Photograph by Norman Seeff/ (rule)/ Limited First Edition; [v] (eight-line quotation from Aleksandr Solzhenitsyn, two-line quotation from Nelson Rockefeller); [vi] The purpose of "Life" is/ S. M. I ${ }^{2}$. L. E./ Space Migration/ Intelligence Increase/ Life Extension; [vii] (nineteen-line note); [viii] blank; [ix] dedication ("to evolutionary agents, on this planet \& elsewhere"); [x] blank; [xi-xii] Preface; [xiii-xiv] Table of Contents; [xv] Part I fly-title; [xvi] blank; 1-134 text; [135-36] blank.

Glossy, black wrappers printed in white. Front cover (repeated on back cover:): TIMOTHY LEARY/ (photograph of the author)/ EXO-PSYCHOLOGY/ A MANUAL ON THE USE OF THE HUMAN/ NERVOUS SYSTEM ACCORDING TO THE/ INSTRUCTION OF THE MANUFACTURERS. Spine: (printed vertically:) TIMOTHY LEARY EXO-PSYCHOLOGY STARSEED/ PEACE PRESS.

Published $1977 @ \$ 6.95 .5,000$ copies printed.

Note: a copy has been seen with the sheets of the first printing bound in a later state (silver wrappers, width $67 / 8$ in., cover photo slightly faded) of the wrappers, indicating a remainder issue.

b. First edition, second printing:

Collates identically to A19a, except p. [iv], last line is replaced by: 09876543

2. Cover identical except wrappers are silver printed in black.

Published1978@\$7.95.4,000 copies printed. 


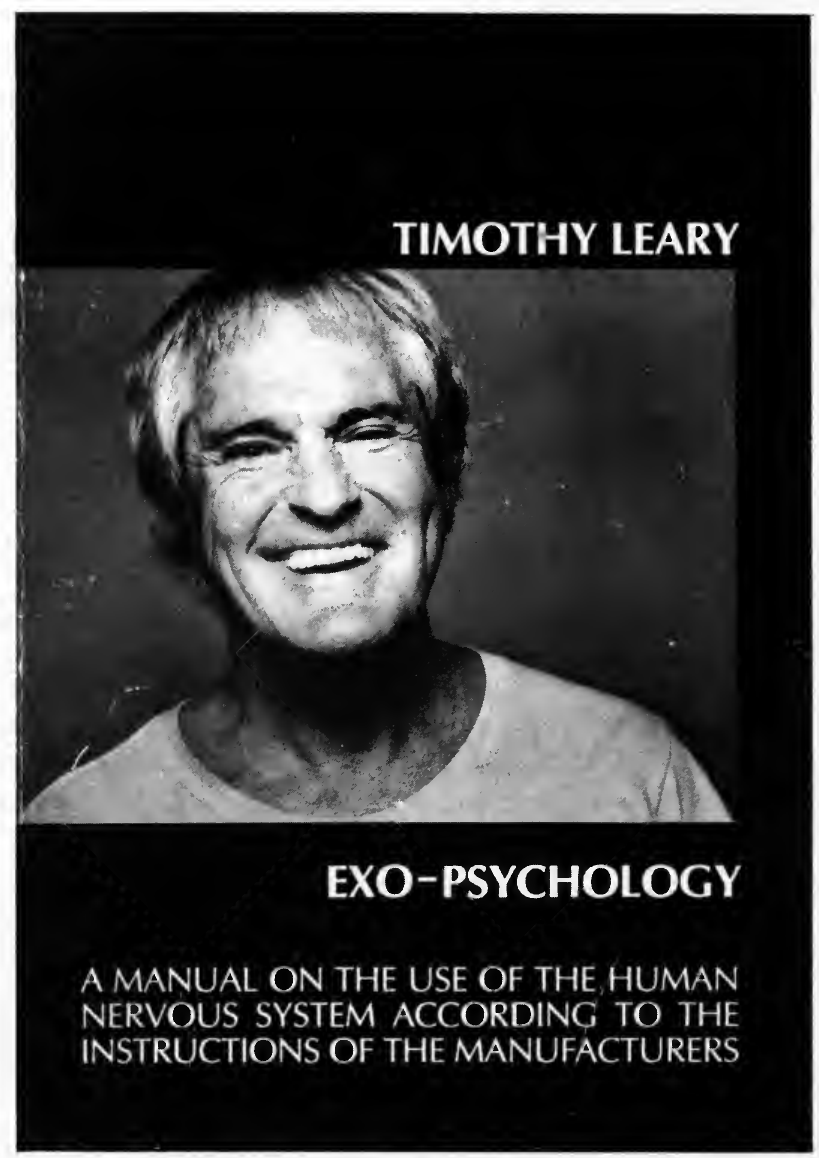

A19a: Leary's manual on exo-psychology (1977) appeared two decades after his manual on psychology (A3). (Info-Psychology is scheduled for 1987.) Courtesy Timothy Leary.

\section{c. First edition, third printing:}

Collates identically to A19a, except p. [iv], last line is replaced by: 09876543 . Cover identical to A19b, except on back cover, price $\$ 7.95$, and ISBN 0-915238-16-0 are printed.

Published Jan.1980@ \$7.95. 5,000 copies printed.

This treatise, written while the author was confined for more than three years in various federal prisons, was published shortly after his release. It deals with "the evolution of the nervous system in its larval and post-terrestrial phases." DNA is the intelligence that directs the evolutionary process through eight "circuits" and 
twenty-four "stages," subdivided into receptive, integrative, and transmittive modes. The book is designed to incorporate signal statements from the text within rules at the top of each page, and beneath another rule as a footnote on each pair of facing pages, the slogan S.M.I'.L.E. on the left-hand page, and "SPACE MIGRATION INTELLIGENCE INCREASE LIFE EXTENSION" on the right. The book Exo-Psychology is a more detailed account of the ideas first presented in Neurologic (A13). Portions of Exo-Psychology were reprinted "with revisions" in Metaphors of Consciousness (BB15). A new, revised edition titled Info-Psychology was scheduled for 1987 publication by Falcon Press.

\section{a. First edition, first printing:}

NEUROPOLITICS/ (rule)/ The Sociobiology of Human Metamorphosis/ Timothy Leary/ with/ Robert Anton Wilson/ and/ George A. Koopman/ (rule)/ A Starseed/ Peace Press Publication • 1977 - Los Angeles, California

$97 / 8 \times 615 / 16$ in. [xxii] $160 \mathrm{pp}$.

[i] half-title; [ii] Books and Monographs by the Author/ (twenty-four lines of titles and dates); [iii] title; [iv] Copyright (C) 1977 by Timothy Leary/ (rule)/ All Rights Reserved/ Published jointly in the United States by Starseed/Peace Press, Inc./ P.O. Box 188 Culver City, California 90230/ Manufactured in the United States/ Printed by Peace Press, Inc./ (four lines of publication data giving LC Catalog Card No.: 77-079606 and ISBN 0-915238-18-7)/ (eleven lines giving printing history of certain chapters)/ Edited by Daniel Gilbertson and George A. Koopman/ Coordinated by Jay Levey/ Designed and illustrated by Cynthia Marsh for Starseed/ Layout by Linda Norlen/ Typesetting by Tin Roof/ Cover design by The Daily Planet/ First Edition October 1977; [v] (rule)/ (five-line quotation from a letter written from prison by Ludwig Wittgenstein to Bertrand Russell, March 1919; [vi] The Tactics of Evolution are:/ (rule)/ Space Migration/ Intelligence Increase/ Life Extension; [vii] The Goal of Evolution is:/ (rule)/ Fusion/ (at higher levels of intensity/ acceleration/ aesthetic complexity); [viii] (rule); [ix] this book is dedicated to/ (rule)/Susan; [x] blank; [xi-xiv] Table of Contents; [xv-xvi] blank; [xvii-xviii] Introduction by Daniel Gilbertson; [xix] blank; [xx-xxi] (occupying left two-thirds of double-page spread a blow-up newsphoto of the author with his daughter and Richard Alpert at Millbrook in 1963; occupying right third of double-page spread the fly-title to Part I); [xxii] blank; 1-160 text. Illustrations on pp. [24], [30], [34], [38], [40], [46], [74], [112], [132], [144].

Glossy, stiff wrappers, printed in purple, black, green, light blue, yellow and white, depicting across both covers and spine a skyline framed (on front cover) by 


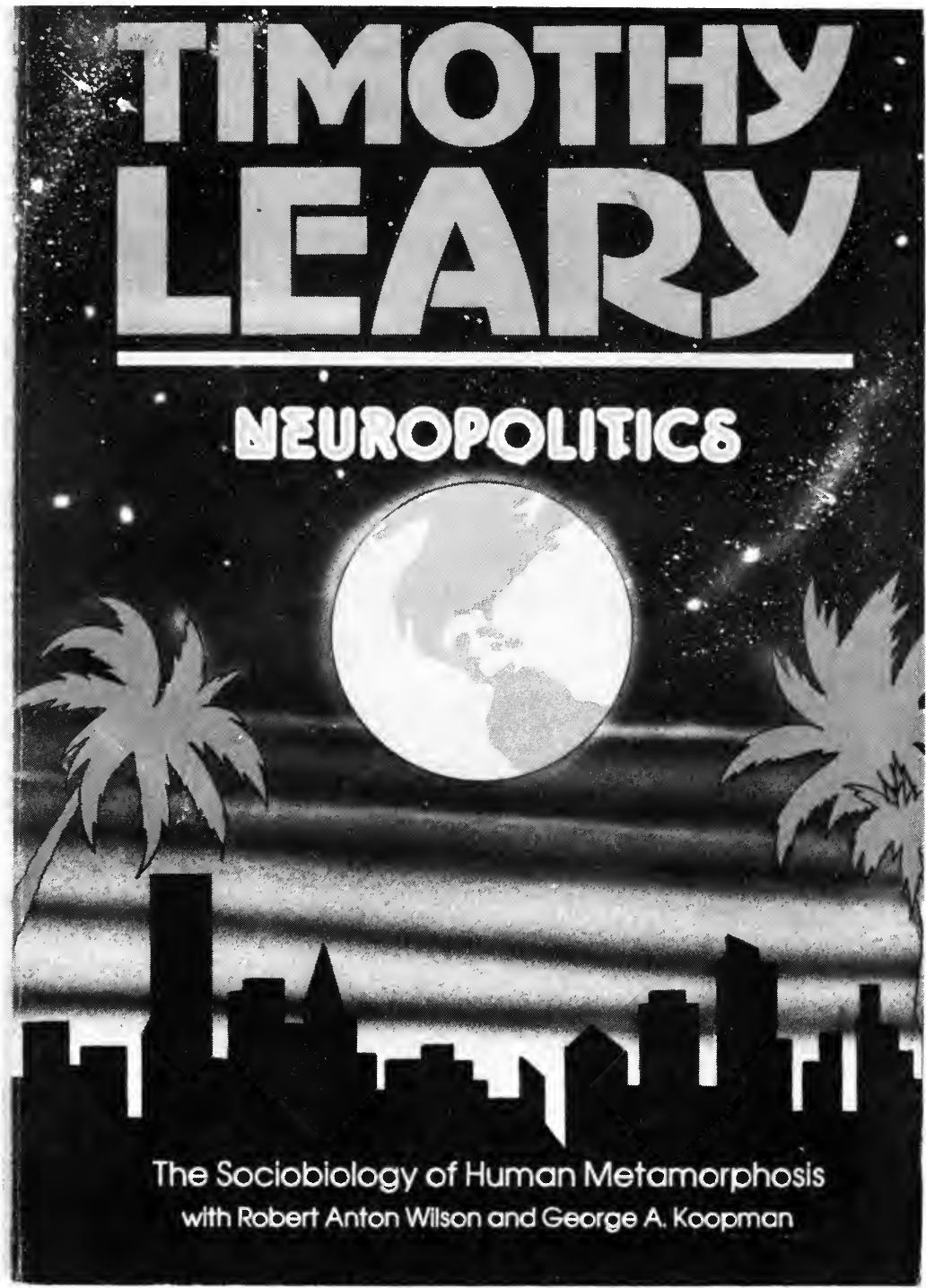

A20a: Collected essays (1977) on social and political issues of the 1970s. Courtesy Timothy Leary. 
two palm trees with the planet Earth in the starry sky. Front cover text: TIMOTHY LEARY/ (rule)/ NEUROPOLITICS/ The Sociobiology of Human Metamorphosis/ with Robert Anton Wilson and George A. Koopman. Back cover: (at lower left:) 6.95. Spine: (printed vertically:) TIMOTHY LEARY NEUROPOLITICS STARSEED/ PEACE PRESS.

Published $1977 @ \$ 6.95$. Undisclosed number of copies (probably 5,000-8,000) printed.

Material previously published elsewhere includes: Chapter 1, "The Seeds of the Sixties," in Forum for Contemporary History (C83); Chapter 2, "The Outlaw Industry" as "TV and the Outlaw Industry" in The National Review (C97); Chapters 3-12 as The Curse of the Oval Room (A17); Chapters 13-14, "How to Wash Brains" (as "Brainwashing") and "Meeting Manson" in Oui (C99 and C100); Chapter 16, "From Inner Space to Outer Space" in Laughing Coyote Magazine (C101a); Chapter 18, "Starseed" (A15); Chapter 21, "In Defense of Snake Oil Salesmen" as "Tim Leary on Snake Oil, Liberals and Amino Uganda" in L-5 Newsletter (C101). Chapters 15, 17, 19, 20 and 22 appear for the first time.

Robert Anton Wilson coauthored Chapters 13, 16 and 17. George A. Koopman coauthored Chapter 22. Neuropolitics is divided in two parts: "The Twilight of Terrestrial Politics" and "The Dawn of Extra-terrestrial Politics." The book is designed similarly to Exo-Psychology (A19), with major ideas set off between rules at the head of the page, and the S.M.I ${ }^{2}$.L.E slogan and definition beneath a rule at the foot of each page.

\section{b. Second printing:}

Collates identically to A20a, except on p. [iv], the last line is replaced by: 98765 43 2. Cover identical. Published in 1978.

\section{a. First edition:}

(first two lines within gray band:) The Intelligence Agents/ TIMOTHY LEARY/ TRANSMISSIONS:/ (twenty-eight lines of chapter titles)/ (C) 1979 by Timothy Leary./ All rights reserved./ Printed in the United States of America by Peace Press, Inc./ ISBN: 0-915238-23-3 Library of Congress: 78-62299

97/8 $\times 7$ in. [vi] 5-214 pp.

[i] (pencil drawing of Barbara Leary)/-To Barbara-; [ii] title with portion of contents and copyright notice; [iii] (within gray band enclosed in a box, set at an 


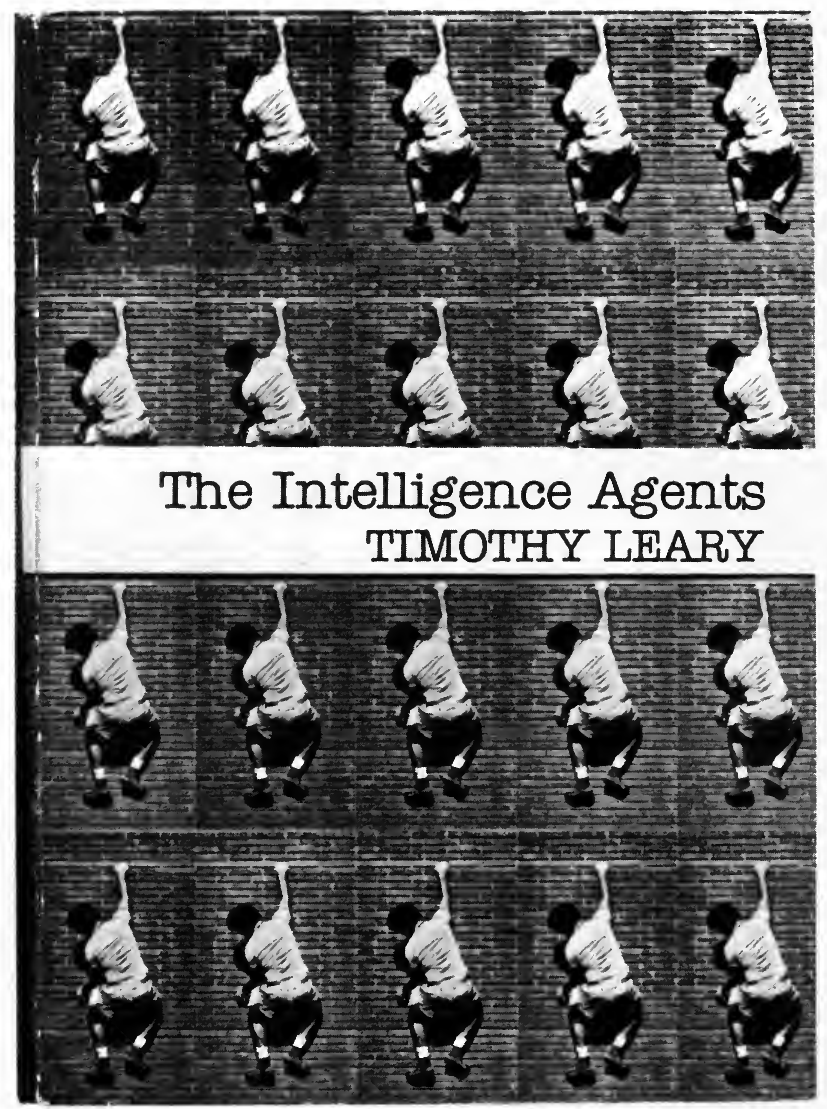

A21a: Ruminations on the concept of intelligence and those who exemplify it (1979). Courtesy Timothy Leary.

angle to resemble rubber stamp:) TOP SECRET/ TRANSMISSIONS:/ (continuation of contents in twenty lines)/ Cover: from an artwork by Susan Kaiser Vogel \& Robert Mangurian/ Publisher: Peace Press, Inc., 3828 Willat Avenue, Culver City, CA 90230/ Sales \& Marketing: Bob Zaugh/ Editor: Dorothy J. Schuler/ (eleven additional lines of production credits); [iv] Books \& Monographs by Timothy Leary/ (twenty-three lines of titles and dates)/ (within box set at angle to resemble rubber stamp:) CONFIDENTIAL/ FILE NO. 4575; [v] (enclosed by a box rule:) COMING/ SOON/ (illustration of slighted parted lips)/ THE GAME/ OF/ LIFE; [vi] Publisher's Disclaimer/ This is a work of social, moral, religious and/scientific satire, set in the future. It does not/ intend to malign any individual, race, organiza-/ tion or religion. It does intend to entertain the/ reader while 
increasing hir [sic] intelligence./ Acknowledgments/ (twenty-five lines set in double column); 5-214 text. Profusely illustrated with photographs, drawings, maps, charts, tables, etc. (charts, maps and designs by Robert Clark).

Glossy, stiff, photographic wrappers in brown, black, and white, depicting a young man climbing sheer brick wall repeated in sequence forty times; white band bisecting illustration across both wrappers, imprinted on front cover: The Intelligence Agents/ TIMOTHY LEARY. Back cover: (at upper left:) 7.95. Spine: (printed vertically:) The Intelligence Agents TIMOTHY LEARY (horizontally:) PEACE/ PRESS. Cover illustration printed in light gray inside wrappers.

Published Mar. 27, $1979 @ \$ 7.95 .8,500$ copies printed. Note: Later copies of the first issue have a price increase shown by a circular sticker pasted over original printed price reading: $\$ 8.95 /$ Peace Press.

\section{b. Second edition:}

Because of threatened legal action by representatives of the Estate of Anaïs Nin, her name as fictional author of "The Ultimate Aphrodisiac," pp. 36-37, and of "The Only Choice," p. 152, is changed in this edition to Anise Nun. The title of the second piece is changed to "The Lesson of the Social Insects." The wording of the "Publisher's Disclaimer," now on p. [v] replacing the ad for The Game of Life, describes the contents as "parodies by the author." An additional credit appears in Acknowledgments and a line reading: 98765432 is added at the foot of p. [iii]. P. 214 is now blank.

Glossy, stiff wrappers, with black and white photograph of author in trench coat, lightning flashing from both sides of his head, against black background, with back to camera on front cover, and face to camera on back cover. Text printed in pink and white. Front cover: The Intelligence Agents/ (dotted line)/ TIMOTHY LEARY. Back cover: (at upper left) \$8.95/ 0-915238-23-3/ (dotted line). Spine: (printed vertically) The Intelligence Agents TIMOTHY LEARY (horizontally) PEACE/ PRESS.

Published Mar. 21, 1980 @ \$8.95. 3,580 copies printed.

The Intelligence Agents is a history of the evolution of human intelligence, presented in a mixture of styles: essays (with authorship assigned to other persons); excerpts from a lecture delivered in Tucson in the winter of 1977; "counter-intelligence agency" reports dated Switzerland, 1972; entries from the "Genetic Hall of Fame"; and a profusion of illustrative material.

The present title is listed among the author's books (p. [iv]) as Vol. IV in the Future History Series, his previous three books (A18-20) constituting Vols. I-III. 
First edition:

"S.M.I'I.L.E."/ SPACE MIGRATION, INTELLIGENCE INCREASE/ AND LIFE EXTENSION/ FOR EVERYONE!/ GREETINGS, FELLOW/ NERVOUS SYSTEMS!/ (at bottom left:) SCRIPT:/ LEARY,/ VON SHOLLY/ AND DICAPRIO - ARTWORK:/ VON SHOLLY - PANEL/ BORDER INKING AND/ LETTERING: KUMMERO/ ASSISTANCE: S. RILEY, L. OCHI,/ B. CLARK (at right:) "NEUROCOMICS"/ HAS EVOLVED FROM THE/ RECENT TRANSMISSIONS OF/ DR. TIMOTHY LEARY/ AS FILTERED THROUGH/ PETE VON SHOLLY/ AND/ GEORGE DI CAPRIO

$10 \times 7$ in. 32 pp.

1-32 illustrated text in comic book form.

Multicolored comic book glossy wrappers, depicting across both covers Timothy and Barbara Leary in a futuristic space scene. Front cover: NEUROCOMICS/ TIMOTHY LEARY/ LAST GASP \$1.25/ PETE VON SHOLLY/ \&/ TIM KUMMERO. Inside front cover: (at bottom:) "NEUROCOMICS" ๔ 1979 PETE VON SHOLLY (ARTWORK) PUBLISHED BY LAST GASP ECO-FUNNIES/ 2180 BRYANT ST. SAN FRANCISCO CA. 94110 BASED ON THE WORKS OF DR. TIMOTHY LEARY/ COVER PAINTING BY TIM KUMMERO. Inside back cover: Advertisement with coupon for the author's most recent books available from Peace Press. Stapled.

Published Mar.1979@ @1.25. 10,000 copies printed.

Neurocomics is a comic book version of The Game of Life (A23). (Copies available @ \$3.00 postpaid from Lasp Gasp, Box 212, Berkeley, CA 94701.)

\section{First edition:}

PEACE PRESS-STARSEED/ Presents/ THE GAME OF LIFE/ Real-ized [sic] by/ TIMOTHY LEARY/ Starring/ The 24 Stages of Your Neurological Tarot/ Directed by Covert Activities/ Robert Clark/Written by Timothy Leary/ Historical and Scholarly Scripts by Robert Anton Wilson/ Edited by Arel Lucas/ Adapted from a Musical Comedy by Barbara Leary/ Special Video Effects by George Di Caprio and Peter Von Sholly/ Graphics by Robert Clark/ Volume V of the FUTURE HISTORY SERIES 


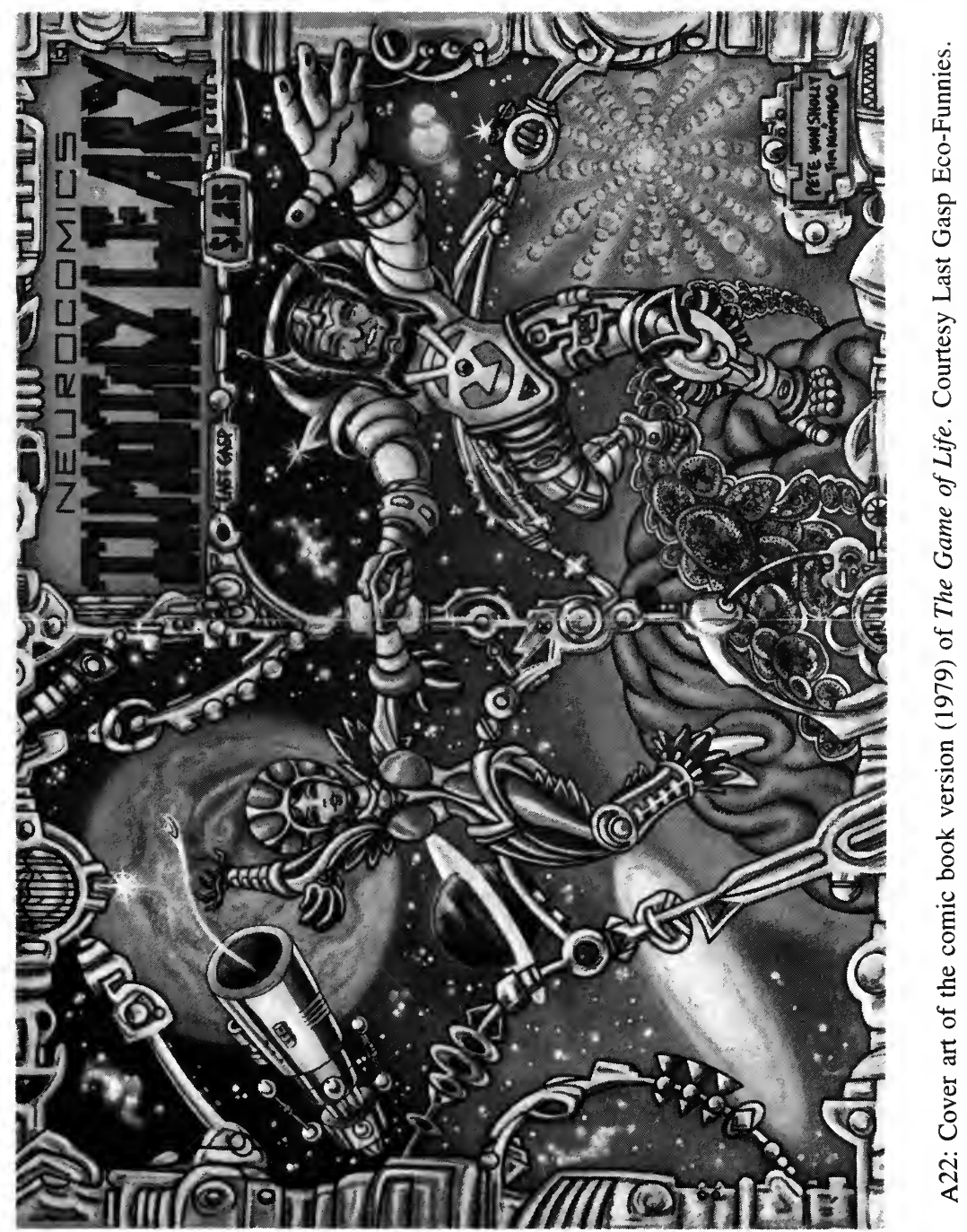




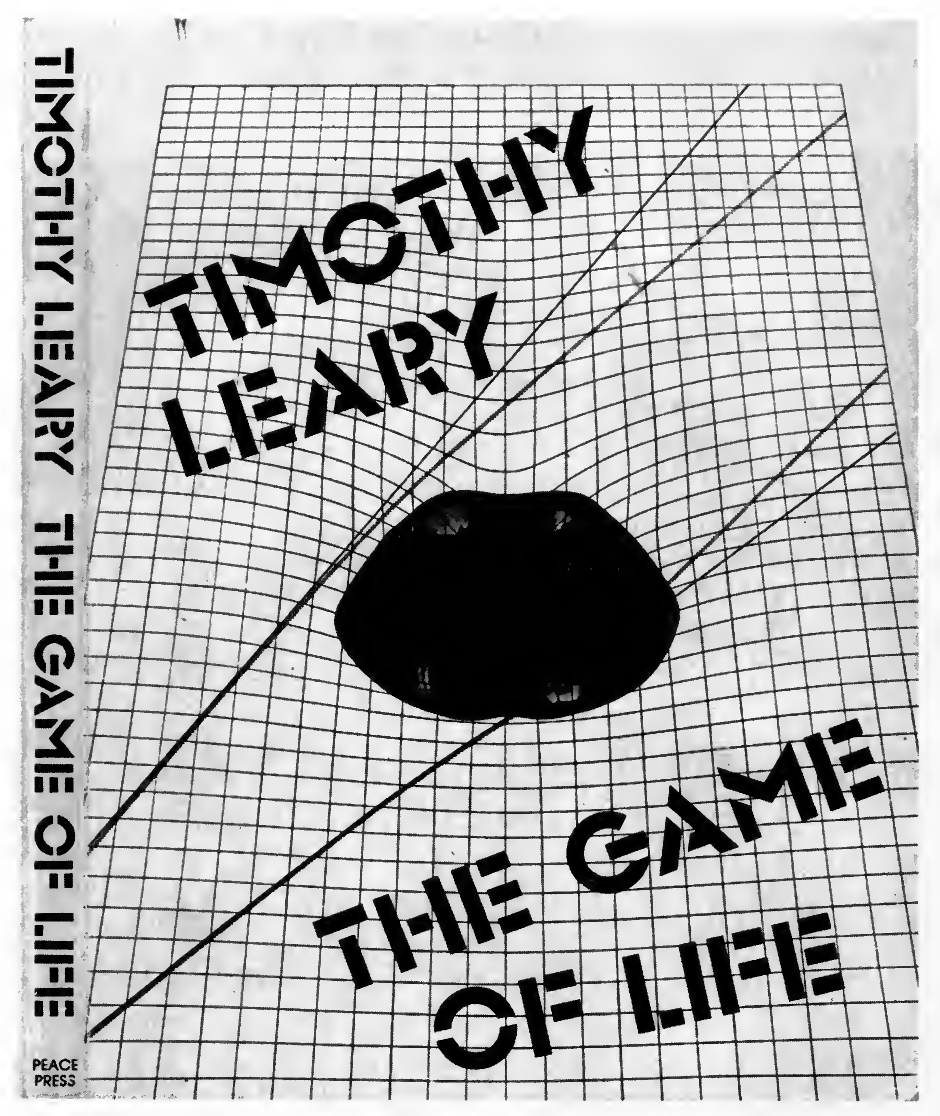

A23: The last of Leary's four Peace Press titles (1979). Courtesy Timothy Leary.

$1015 / 16 \times 85 / 16$ in. [x] 294 pp.

[i] title; [ii] (within box rule:) Books and Monographs by Timothy Leary/ (twenty-three lines listing previous books and dates)/ (beneath box rule:) (C) 1979 by Timothy Leary. All rights reserved./ Printed in the United States of America by Peace Press, Inc./ (seven lines of LC data giving catalog no: 79-2283/ ISBN 0-915238-30-6); [iii] Editorial by Arel Lucas; [iv] Intelligence Agent Awards/ (four photographs, with names printed beneath, of Robert Anton Wilson, Robert Clark, Arel Lucas, Joe Kaufman)/ (eighteen lines of production credits); [v] Dedication (to Ashley Martino, Zachary Chase, Diedra Martino with photograph of each); [vi-vii] Index of Transmissions; [viii-ix] author's note; [x] fly-title to Part I; 1-288 text; [289-90] Foot Notes [sic]; [291-92] Appendix; [293-94] Earth Camp One (letter to author from "Commander Jason Sailsky"). Profusely illustrated with photographs, drawings, license forms, tarot cards, etc. 
Glossy, yellow wrappers illustrated in white, red and pink, with text printed in black. Front cover: (across graph lines being sucked into black hole between parted female lips:) TIMOTHY/ LEARY/ THE GAME/ OF LIFE. Back cover: (Price and ISBN upper left)/ THE GAME OF LIFE/ (three blurbs dated 1999). Spine: (printed vertically:) TIMOTHY LEARY THE GAME OF LIFE (horizontally:) PEACE/ PRESS.

Published Apr. 11, $1980 @ \$ 8.95 .8,590$ copies printed.

The Game of Life represents a continuation of the content and style of Neurologic (A13) and the previous four works in the Future History Series, particularly Exo-Psychology (A19): the evolutionary development of the human nervous system in eight circuits and twenty-four stages, from the earliest life-forms of the species to a proposed extraterrestrial destiny of black hole fusion into another universe. The primary metaphor used is a new tarot deck keyed to the neurological levels. References to the I Ching, signs of the zodiac, scientific history, popular folklore and contemporary personalities abound.

A24 CHANGING MY MIND, AMONG OTHERS

1982

\section{a. First edition:}

CHANGING/ MY MIND,/ AMONG/ OTHERS/ Lifetime writings,/ selected and/ introduced by/ the author/ Timothy Leary/ Prentice-Hall, Inc., Englewood Cliffs, New Jersey 07632

$91 \frac{1}{4} \times 6$ in. xiv, $274 \mathrm{pp}$.

[i] half-title; [ii] Books and Monographs by Timothy Leary/ (rule)/ (twenty-four lines of previous titles and dates); [iii] title; [iv] For Barbara and Zachary/ Book design by Joan Ann Jacobus/ Art Director: Hal Siegel/ Changing My Mind, Among Others:/ Lifetime writings, selected and introduced by the author/ (C) 1982 by Timothy Leary/ (eight lines regarding rights and publisher's locations)/ 10987 65432 1/ ISBN 0-13-127811-8/ ISBN 0-13-127829-0 [PBK]/ (six lines of LC data giving catalog no. 81-17784); [v] Homage (to Julien Offray de Le Mettrie and Christopher Columbus); [vi] blank; [vii]-viii Contents; [ix]-xiii Introduction; [xiv] blank; [1]-267 text; 268-74 Index.

Shiny yellow boards, printed in bright red on spine: (vertically:) LEARY CHANGING MY MIND, AMONG OTHERS (horizontally:) PRENTICE/ HALL. On back cover, lower right, in red: the ISBN no. Dust jacket red shading to yellow, printed in black and white (almost identical to covers of A24b). White endpapers.

Published Mar. 29, $1982 @ \$ 15.95$. Undisclosed number of copies printed, but probably not more than 2,000 . 


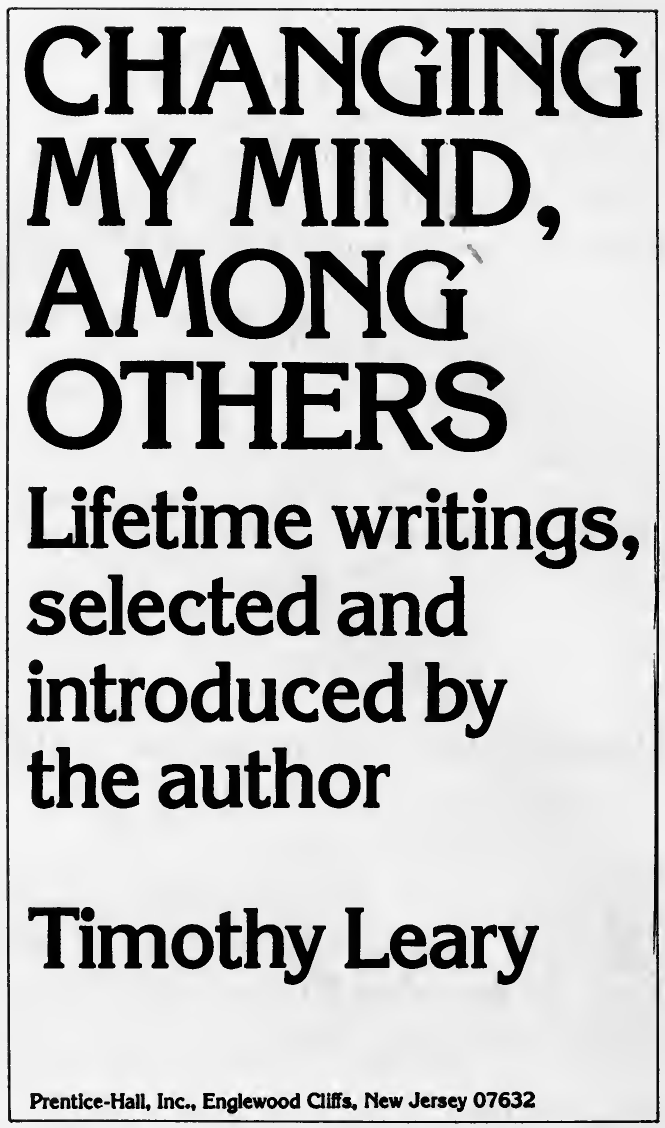

A24a: On developments in American psychology since World War II and Leary's work in the field (1982). Courtesy Prentice-Hall, Inc.

b. First (simultaneous) paperback edition:

$9 \times 6$ in.

Collates identically to A24a.

Glossy wrappers of red (top) shading to yellow (bottom), printed in black and white. Front cover: TIMOTHY/ LEARY/ CHANGING/ MY MIND,/ AMONG/ OTHERS/ Lifetime writings,/ selected and/ introduced/ by the author. Back cover: (upper left:) publisher's device A Reward Book/ Psychology (upper right:) $\$ 7.95$ / diagram of interpersonal behavior circle/ (three-paragraph quotation from book)/ (rule)/ (five lines biographical note)/ (at left:) Jacket Design by Hal Siegel/ 
PRENTICE-HALL/ Englewood Cliffs, N.J. (at right:) ISBN 0-13-127811-8. Spine: (printed vertically:) LEARY CHANGING MY MIND, AMONG OTHERS/ (horizontally:) publisher's device for series.

Published Mar. 29, $1982 @ \$ 7.95 .7,500$ copies printed.

A selection made by the author of his own writings, consisting primarily of excerpts from works published between 1956 and the present, interspersed with his extensive commentary written especially for this edition.

\section{a. First edition:}

FLASHBACKS/ An Autobiography/ Timothy Leary/ (publisher's device)/ J. P. TARCHER, INC./ Los Angeles/ Distributed by Houghton Mifflin Company/ Boston

$9 \times 6 \frac{1}{4}$ in. 400 pp.

[1] half-title; [2] Books and monographs by Timothy Leary (twenty-eight lines of publishing data); [3] title; [4] (nine lines of LC publication data giving catalog no. 82-16915)/ Copyright (C) 1983 by Timothy Leary/ (six lines pertaining to reproduction rights)/ (three lines giving publisher's name and address)/ Designed by John Brogna/ Edited by Stephanie E. Bernstein/ MANUFACTURED IN THE UNITED STATES OF AMERICA/ S 1098765432 1/ First Edition; [5] dedication (To Barbara and All the Children); [6] Acknowledgments; [7-8] Contents; 9-11 Prologue; [12] blank; [13] fly-title to Part I; [14] blank; 15-331 text; [*] blank; (fifteen-page photographic inset); 332-76 text; 377-95 Notes; [396-97] chart; [398-400] blank.

Black half cloth and black boards, spine lettered in pink: (vertically:) LEARY FLASHBACKS/ (horizontally:) TARCHER/ (rule)/ HOUGHTON/ MIFFLIN/ COMPANY. Turquoise endpapers.

Silver dust jacket lettered in dark red and turquoise on front panel and spine; back panel has photograph of author, with ISBN number in small rectangular inset lower right. Jacket design credited to John Brogna and Ron Coro; jacket photo credited to Alice Springs.

Published May 30, $1983 @ \$ 15.95$. 17,500 copies printed. In May 1984, 4,166 copies of the publisher's stock had their covers torn off and replaced by paperback covers. These copies are distinguishable from the paperback reprint (A25c) in having the printed series of numbers end with " 1 " and the words "First edition" on p. [4]; also, the turquoise endpapers are retained. Size: $9 \times 57 / 8$ in. 


\title{
FLASHBACKS
}

\section{An Autobiography}

\author{
Timothy Leary
}

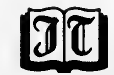

J. P. TARCHER, INC.

\section{Los Angeles}

Distributed by Houghton Mifflin Company

Boston

A25a: Leary's illustrated autobiography (1983), beginning with his conception on the night before alcohol prohibition began in 1919. Courtesy J.P. Tarcher, Inc.

Three leaves are cancels: pp. 289-90, 333-34, and 349-50. These pages were replaced with a slightly altered text; names and references were deleted. About sixty copies marked "uncorrected proof" bound in green wrappers printed in black were circulated with the uncancelled leaves in Feb. 1983.

\section{b. First British edition:}

FLASHBACKS/ An Autobiography/ Timothy Leary/ (publisher's device) HEINEMANN: LONDON

Photo-offset from A25a, to which it collates identically, except for title page and p. [4], which reads as follows: (four lines giving publisher's name, address and 
location of offices)/ (C) Timothy Leary 1983/ First published 1983/SBN 43440975 8/ Printed and bound in Great Britain by / R. J. Acford/ Chichester, Sussex.

Black cloth, spine stamped in gilt: FLASHBACKS/ Timothy/ Leary/ (publisher's device). White endpapers. Dust jacket black printed in white and pink, with silver stars emerging from a pink-striped American flag; back panel photograph of author, with quotations from reviews.

Published Oct.10,1983@£9.95. Undisclosed number of copies printed.

\section{c. First paperback edition:}

$91 / 4 \times 61 / 8$ in.

Collates identically to A25a, except for the following alterations on p.[4]: ISBN 0-87477-317-2 (ppbk.) is added after line 7; editor's name is deleted; the final number " 1 " is dropped from the printing series and the words "First Edition" are deleted.

Glossy silver wrappers printed in turquoise, burgundy and black. Front cover: (separated by four bands:) FLASH/ BACKS/ AN AUTOBIOGRAPHY/ TIMOTHY/ LEARY. Back cover: (upper left:) Biography/ History (upper right:) (price)/ (publisher's blurb and quotations from statements and reviews by Tom Robbins, William Burroughs, Andrew Weil, and others)/ (lower left:) Cover design: John Brogna and Ron Coro/ (name of publisher and distributor/ (two series of numbers separated by rule) (at right:) (ISBN no. within white band).

Published May $1984 @ \$ 9.95 .8,907$ copies printed. In addition, 4,166 copies of the hardbound issue had their covers torn off and replaced with paper covers (see note to A25a), thus putting 13,073 of the paperback issue in circulation.

The author's first full-length autobiography, embellished with photographs, mostly unpublished, from various periods of his life, depicting other family members and important associates and events. Each of the forty-one chapters is prefaced with a biographical notice of celebrated historical and contemporary figures, researched and written by the author and Michael Horowitz. There is a Prologue and Epilogue followed by Notes in small print, followed by a double-page chart of "Four Generations Inhabiting America (1983)." On p. 293 is a map showing Leary's 1970 prison escape. This book generated controversy before it was published because of threatened legal suits, including one by the CIA; certain names and affiliations had to be deleted, resulting in a several-months delay in publication.

Excerpts from the book appeared in a somewhat altered form in Psychology Today (July 1983)—see C132. 


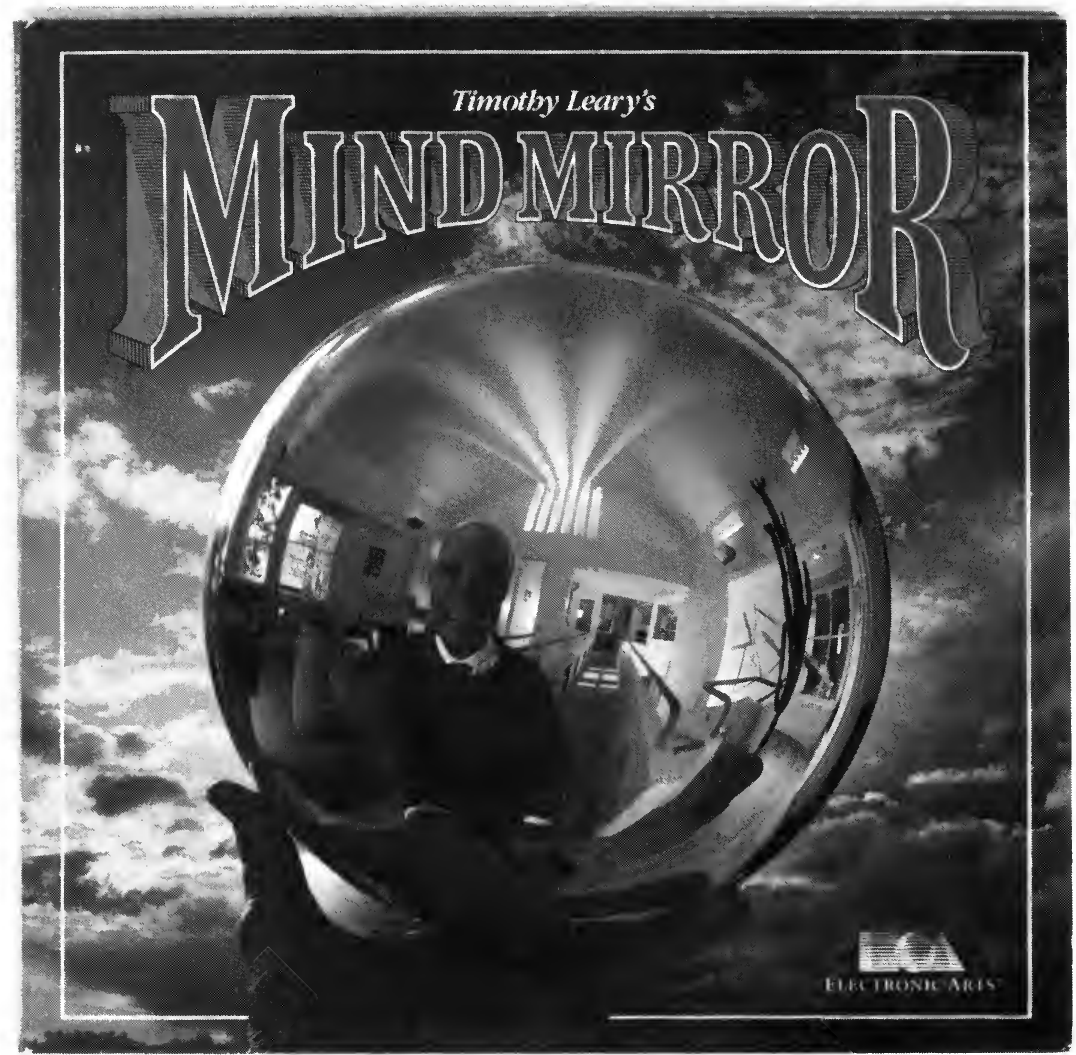

A26: Software Jacket of Leary's first "electronic book" (1986). Courtesy Electronic Arts.

First edition:

(within white box rule:) Timothy Leary's/ (thin rule)/ (in three-dimensional block letters:) MIND MIRROR/ (photo-portrait of author, left profile, within oval frame)/ (at lower right:) The Manual (cover title) 
$73 / 4 \times 73 / 4$ in. $20 \mathrm{pp}$.

[1] cover title, as above; [2] NOTICE/ (eighteen lines pertaining to reservation of rights, copyright protections, and warranties)/ SOFTWARE C FUTIQUE, INC./ MANUAL BY TIMOTHY LEARY AND NICHOLAS LAVROFF/ C) 1986 ELECTRONIC ARTS; 1 Table of Contents; 2-17 text (each page bordered top and bottom with line rule); [18] (publisher's device)/ ELECTRONIC ARTS TM/ Electronic Arts, 1820 Gateway Drive, San Mateo, CA 94404./ 114205 PRINTED IN U.S.A.

Self-wrappers; stapled. Manual is inserted in pocket of software jacket, which is imprinted with color photographs and lettered in black, white, green and orange. Front panel: (repeats white box rule and lettering of cover of manual:) Timothy Leary's/ MIND MIRROR/ (photograph of hand holding convex lens containing image of author against background of sky with clouds). Back panel: (extensive descriptive text describing software, with two photoreproductions showing graphic data on screen and quotations from Manual). Double inner panels: (five photographs of author with quotation from the Manual and the following publication data:) Designed and written by Timothy Leary, $\mathrm{PhD} /$ Programmed by Peter van den Beemt \& Bob Dietz/ (seven additional lines of credits)/ Package design (C) 1986,/ Electronic Arts Software/ C 1986, Futique. Simultaneously published in/ Canada and the U.S.A. Screenshots represent IBM PC/ only. Other versions may vary. (PC is a registered/ trademark of IBM.)/ (three lines of additional trademark registrations). Spine: MIND MIRROR ELECTRONIC ARTS.

Floppy $51 / 2$ in. disk, MSDOS format, inserted in software jacket. (Note: This format is for an IBM computer system; other formats were produced for Apple and Commodore systems.)

Published May $1986 @ \$ 32.95$ to $\$ 35.95$. Undisclosed number of copies produced.

Leary spent several years creating this computer game designed "as a thought processor, headware for the computer generation. It allows you to interface with virtually any concept or personality, and helps put your thoughts into digital form" (blurb). Unlike computer programs used for business procedures, Mind Mirror employs the psychometric measures the author began developing in the 1950s to enable the user to "expand consciousness, to increase intelligence, to score and improve Life Performance" (Leary). Mind Mirror offers "Rating Games," "Mind Play \& Mind Tools," and "Life Simulations." 


\title{
AA. \\ Monographs, Offprints, Mimeographed Reports and Broadsides
}

\author{
AA1 CLINICAL USE OF WECHSLER
}

First appearance:

The Clinical Use of the Wechsler/ Mental Ability Scale: Form B/ (at lower right:) Washington State/ Timothy Leary/ 1946

$10 \frac{1}{8} \times 73 / 4$ in. 99 leaves.

[i] title (on yellow paper); [1]-95 text; 96-98 bibliography.

Typescript. Copy examined bound in green buckram, spine lettered vertically in gilt: CLINICAL USE OF WECHSLER.

The author's thesis submitted for his Master of Science degree from the psychology department of Washington State College. The copy examined is the carbon retained for his use by the author. Original presumably on file with the college.

The thesis is presented in seven chapters, as follows: I. Introduction; II. Historical Summary and Critique of Wechsler-Bellevue as a Diagnostic and Clinical Instrument; III. A Description of the Wechsler Mental Ability Scale Form B; IV. Presentation and Discussion of the Statistical Data Basic to this Study; V. Analysis of Individual Subtests; VI. The Clinical Use of the Form B Scale; VII. Examples of the Clinical Use of the Classification Profile. Summary and Bibliography follow the text.

Leary later (1977) retitled his thesis “The Dimensions of Intelligence." 

SOLVING RACE RELATIONS

First separate printing:

PROGRESS TOWARD SOLVING THE PROB-/ LEM OF RACE RELATIONS

$9 \times 6$ in. 4 pp.

[1]-4 text, preceded by title. At top of [1]: Reprinted from SCHOOL AND SOCIETY, July 20, 1946/ Vol. 64, No. 1647, pages 41-43. At end of text, p. 4: Timothy Leary/ T. H. Kennedy/ The State College of Washington,/ Pullman.

Folded leaf, issued without wrappers.

Offprinted from the journal article (C3) in a limited number of copies for the authors' use.

Cultural observations show that "in every city in the nation signs of progress in race relations are seen." This is Leary's first published paper. Coauthored with T. H. Kennedy.

\section{AA3 COMMUNIST THOUGHT ON THE NEGRO}

First separate printing:

Communist Thought on the Negro

$10 \times 7$ in. Pp. 116-23.

116-23 text, preceded by author's names (T. H. Kennedy and T. F. Leary) and title.

Gray wrappers printed in red, within ruled border: PHYLON/ THE ATLANTA UNIVERSITY/ REVIEW/ OF/ RACE \& CULTURE/ A Reprint/ (at lower left:) From:/ Vol. VIII No. 2/ 1947 (at lower right:) ATLANTA UNIVERSITY/ Atlanta 3, Georgia. Stapled.

Offprinted from the journal article (C4) in a limited number of copies for the authors' use. This is Leary's second published paper, coauthored with T. H. Kennedy. It deals with "the basic philosophies of the Communist Party as related to the Negro in the United States." 


\section{First appearance:}

[Patterns of Social Interaction and their. Relation to Personality Structure]

Coauthored with Abel G. Ossorio.

Paper presented at the annual meeting of the American Psychological Association, Division of Personality and Social Psychology, on Sept. 5, 1950. Cited in: American Psychologist 5, no. 7 (July 1950):303. Not seen.

"This paper reports the findings concerning the relationships existing between social interaction patterns in a group therapy situation and individual personality structure as revealed by other data."

\section{AA5 SOCIAL DIMENSIONS OF PERSONALITY}

\section{First appearance:}

The Social Dimensions of Personality:/ Group Structure and Process/ By/ Timothy Francis Leary/ A. B. (University of Alabama) 1945/ M. S. (Washington State College) 1946/ DISSERTATION/ Submitted in partial satisfaction of the requirements for the degree of / DOCTOR OF PHILOSOPHY/ in/ Psychology/ in the/ Graduate Division/ of the/ UNIVERSITY OF CALIFORNIA/ Approved:/ (three lines of signatures)/ Committee in Charge/ Deposited in the University Library (stamped date) NOV 131950 (followed by signature of Librarian)

$11 \times 8 \frac{1}{2}$ in. vi, 84 leaves.

[i] title; ii Acknowledgments; iii-iv Table of Contents; v-vi List of Tables; 1-77 text; 78-81 Appendix Tables I, II, III, IV; 82-84 Bibliography.

Typescript. Copy examined unbound.

The author's doctoral dissertation submitted to the psychology department of the University of California, Berkeley. The copy examined is the one on file with the university.

"This dissertation is concerned with the development of objective measurements of interpersonal behavior in group therapy." A footnote describes "the present research [as] part of a collaborative investigation into the Social Dimensions of 
Personality which has been carried on over a period of three years by Hubert S. Coffey, Ph.D., Mervin B. Freedman, Timothy Leary, and Abel Ossorio."

The dissertation is presented in seven chapters, as follows: I. Introduction; II. Theory and Practice of Group Therapy-An Historical Review; III. Research Plan: Specific Hypotheses; IV. Temporal Phases in Group Therapy; V. Changes in Individual Patients during Group Therapy; VI. Some Effects of Therapist Behavior on Patient's Improvement from Psychotherapy; VII. Summary and Conclusions. Appendix and Bibliography follow the text.

\section{AA6 MEASUREMENT OF THE GROUP PROCESS}

\section{First appearance:}

[Measurement of the Group Process and the Nature of Therapeutic Improvement in Group Psychotherapy]

Coauthored with Mervin B. Freedman, Hubert S. Coffey and Abel G. Ossorio.

Paper presented to the Western Psychological Association at their annual meeting in the summer of 1951. Announcement and abstract printed in American Psychologist 6, no. 9 (Sept.): 499. Not seen.

"The rated interpersonal behavior of seven patients during 48 hours of group therapy was compared with pre- and post-therapy test batteries and sociometric rankings of improvement. Three different temporal sequences of interpersonal behavior during group therapy were found. Changes in interpersonal role were significantly related to six indices of improvement and to variation in therapist's interpretative activity."

\section{AA7}

\section{a. First separate printing:}

THE INTERPERSONAL DIMENSION OF/ PERSONALITY/ $B y$ MERVIN B. FREEDMAN AND TIMOTHY F. LEARY/ University of California and Permanente Foundation Hospital/ ABEL G. OSSORIO/ Washington University, St. Louis, Mo./ HUBERT S. COFFEY/ University of California/ Reprinted from JOURNAL OF PERSONALITY/Vol. 20, No. 2, December, 1951 (cover title) 


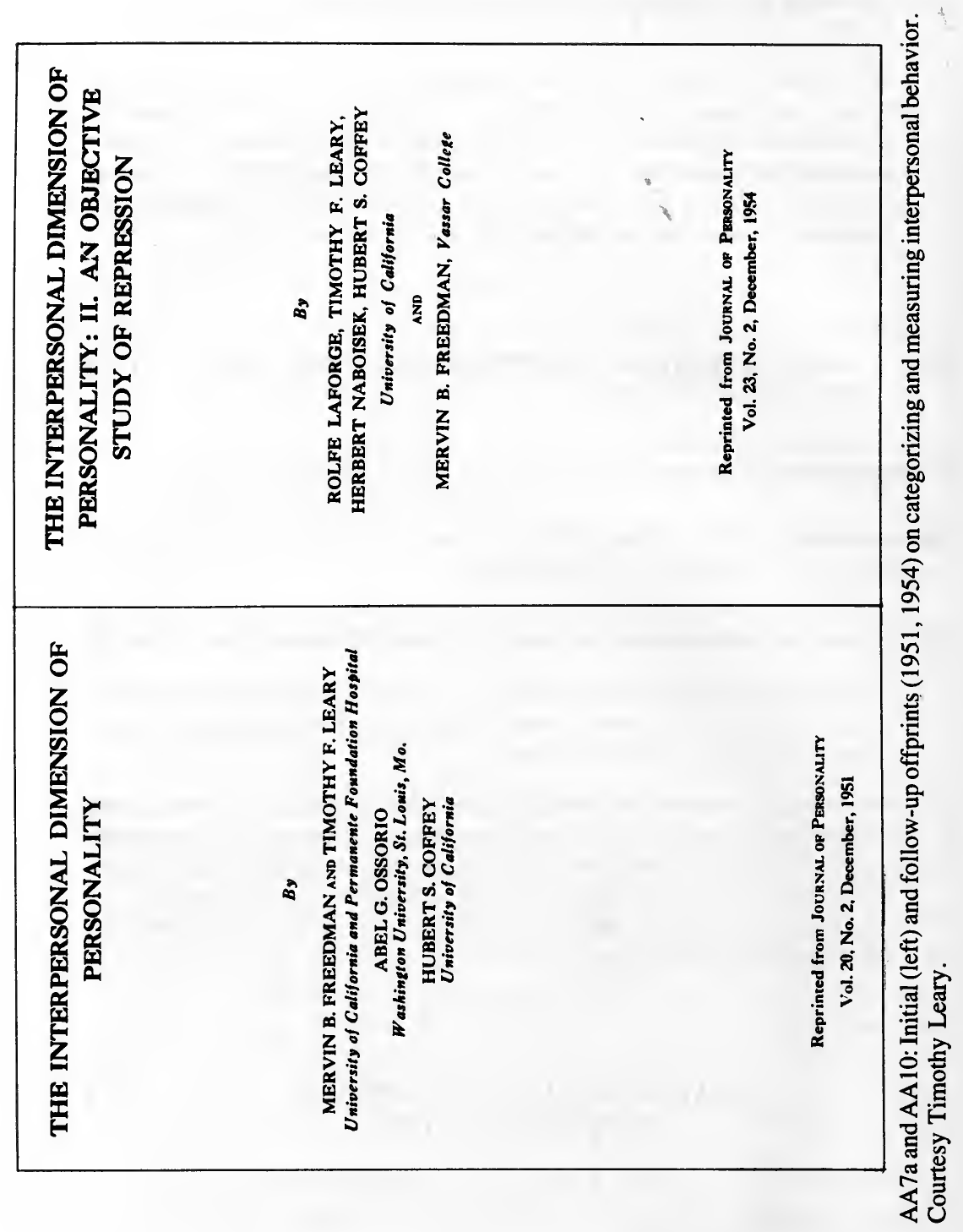


Variant A: $91 / 4 \times$ x 6 in. Variant B: $81 \frac{1}{2} \times 53 \frac{1}{8}$ in. Pp. 143-62.

[143]-161 text, with 2 text figures; [162] blank.

Variant A: tan wrappers printed in black; stapled. Variant B: cream wrappers printed in black; stapled.

Offprinted from the journal article (C8) in a limited number of copies for the authors' use.

\section{b. Second separate printing:}

Photo-offset reprint of AA6a, printed in blue, text within blue borders.

$11 \times 8 \frac{1}{2}$ in. Self-wrappers.

P-116 of the Bobbs-Merrill Reprint Series in the Social Sciences. Price: 25 cents. Number of copies printed unknown, but probably substantially more than the usual offprint as this was part of an advertised series.

"This is the first in a series of papers designed to present a comprehensive schema for the organization of personality data." Four criteria are used, and the data for the "total personality" is divided into the Public Level, Conscious Level, and Private Level. This was a four-year collaborative research study involving 200 subjects. The two text figures are early versions of the Interpersonal Check List (ICL), also known as the Interpersonal Behavior Circle.

Cited in Evaluation in Mental Health (1955), no. 855.

\section{AA8 VARIABILITY DIMENSION OF PERSONALITY 1953}

\section{First appearance:}

\section{[The Variability Dimension of Personality]}

Kaiser Foundation Research Project Staff Report written by Leary in 1953. Cited in references to AA9b. Not seen. 


\section{AA9 PREDICTION OF INTERPERSONAL BEHAVIOR 1954}

\section{a. First appearance:}

The Predictión of Interpersonal Behavior in Group Psychotherapy/ by/ Timothy Leary, Kaiser Foundation and Hubert S. Coffey, Univ. of Calif. (at top:) Psychodrama and Group Psychotherapy Monographs, No. 28/ Beacon House, 1955

$11 \times 8 \frac{1}{2}$ in. 69 leaves.

[1]-69 text, with twelve text-figures. Between pp. [5] and 6 is an unnumbered diagram on different paper stock, "Classification of Interpersonal Behavior into 16 Mechanisms or Reflexes."

Mimeographed; stapled. Issued without wrappers.

Close examination reveals that the lines typed at the top of $p$.[1] which contain the date 1955 were added later, as were typed additions to references 5 and 10-12 on p. 69. This mimeographed format constitutes the first printing of this monograph; internal evidence shows it was produced prior to the journal printing (C9) in May 1954 (the copy examined, with manuscript corrections, was probably the one used to set up the journal printing). The unnumbered diagram, herein called the Interpersonal Diagnostic Circle, is a more advanced version of what was later known as the Interpersonal Check List.

\section{b. First separate (revised) printing:}

The Prediction of Interpersonal/ Behavior in Group Psychotherapy/ BEACON HOUSE, 1955/ PSYCHODRAMA AND GROUP PSYCHOTHERAPY MONOGRAPHS, NO. 28

$9 \times 6$ in. 48 pp.

[1] title; [2] blank; 3-47 text, with twelve text figures; [48] blank.

Red paper wrappers printed in black within rule. Front cover: reproduces text of title page adding authors' names, affiliations, and rule border. Back cover: list of twenty-eight monographs in series, no. 28 being the present title, priced at $\$ 2.75$. Stapled.

Revised printing of both the mimeographed paper (AA9a) and the journal article (C9), with minor revisions and corrections in the text and more substantial ones in the page of references. 


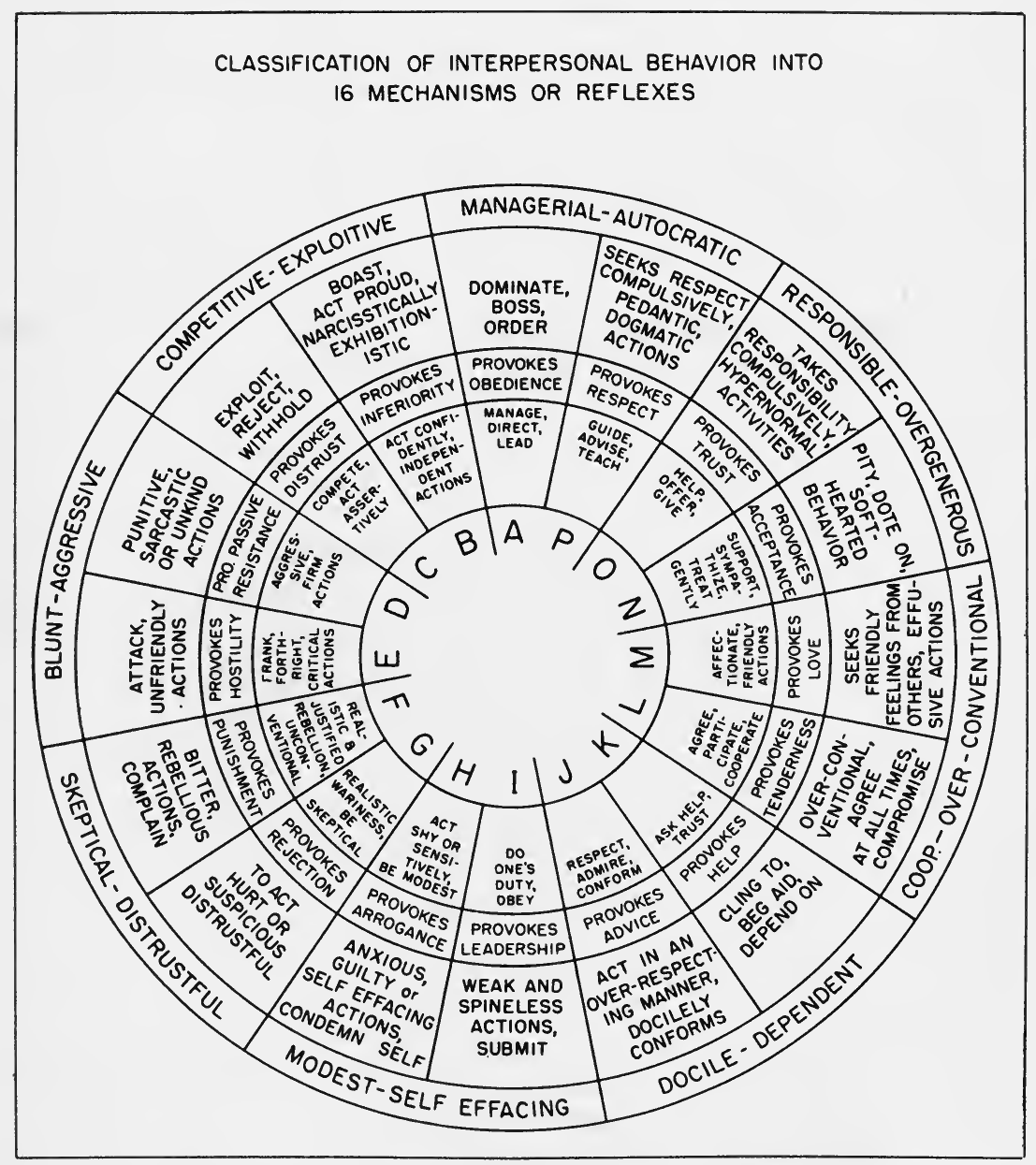

AA9a: Advanced version of the Interpersonal Diagnostic Circle (later known as the Interpersonal Check List), published in 1954. Courtesy Timothy Leary. 
A carbon copy of a letter laid in the copy examined indicates that this monograph was in print in December 1954. Number of copies unknown.

An oft-cited monograph "concerned with methods for predicting what patients do in group psychotherapy," giving "the methods of measurement . . . methods of prediction, and some of the techniques for assessing the kind and amount of variability to be expected." OF PERSONALITY: II

First separate printing:

THE INTERPERSONAL DIMENSION OF/ PERSONALITY: II. AN OBJECTIVE/ STUDY OF REPRESSION/ By ROLFE LAFORGE, TIMOTHY F. LEARY,/ HERBERT NABOISEK, HUBERT S. COFFEY/ University of Californial AND/ MERVIN B. FREEDMAN, Vassar College/ Reprinted from JOURNAL OF PERSONALITY/ Vol. 23, No. 2, December 1954 (cover title)

$81 / 2 \times 53 / 8$ in. Pp [2] [129-54].

[1-2] blank; [129]-153 text, with six text figures; [154] blank.

Tan wrappers printed in black; stapled.

Offprinted from the journal article (C10) in a limited number of copies for the authors' use.

"An empirical study in which repression as rated on the basis of MMPI profiles is correlated with repression as measured in accord with the Interpersonal System of Personality." This is a continuation of AA6. A third and concluding part of this work, "The Interpersonal Dimensions of Personality: III. An Interpersonal Check List, by Rolfe LaForge and Robert F. Suczek," was published in Sept. 1955 (see J4).

First separate printing:

(thick/thin double rule)/ INTERPERSONAL DIAGNOSIS: SOME PROBLEMS OF/ METHODOLOGY AND VALIDATION/ (rule)/ (at left:) TIMOTHY LEARY/ Kaiser Foundation (at center:) AND (at right:) HUBERT S. COFFEY/ University of California/ Reprinted from THE JOURNAL OF ABNORMAL 
AND SOCIAL PSYCHOLOGY, Vol. 50, No. 1, January, 1955/ Copyrighted 1955 by American Psychological Assoc. Printed in U.S.A. (cover title)

$10 \times 65 / 8$ in. Pp. [109] 110-24.

[109] blank; 110-24 text, with nine text figures all based upon the Interpersonal Check List. At end of text: Received March 12, 1954. Prior publication.

Blue wrappers printed in black, stapled.

Offprinted from the journal article (C11) in a limited number of copies for the authors' use. There was apparently a ten-month delay in the publication of the article. No "prior publication" has been noted.

Presents the problems and offers solutions for developing an interpersonal diagnostic system for the study of personality.

AA12

$$
\begin{aligned}
& \text { THE THEORY AND MEASUREMENT } \\
& \text { METHODOLOGY OF } \\
& \text { INTERPERSONAL COMMUNICATION }
\end{aligned}
$$

First separate printing:

[The Theory and Measurement Methodology of Interpersonal Communication]

Reprinted from Psychiatry 18, no. 2 (May 1955) :147-61, with one text figure. Offprint form (of $\mathrm{C12}$ ). Not seen but presumed to exist.

A description of "some methods that the Kaiser Foundation has developed for isolating and defining human interactions. Two theoretical implications are "the principle of self-determination" and "the principle of reciprocal interpersonal relations." This is the first journal publication by Leary published under his name alone.

\section{AA13 CHANGES IN PSYCHONEUROTIC PATIENTS WITH AND WITHOUT PSYCHOTHERAPY}

First separate printing:

Changes in Psychoneurotic Patients/ With and Without Psychotherapy/ Frank Barron/ Institute of Personality Assessment and Research, University of California, Berkeley/ and Timothy F. Leary/ Kaiser Founda- 
tion Hospital, Oakland, California (at upper left:) Journal of Consulting Psychology/ Vol. 19, No. 4, 1955

$81 \frac{1}{2} \times 5 \frac{1}{2}$ in. Pp. $239-45$.

239-45 text, preceded by title. Issued without covers; stapled.

Offprinted from the journal article (C13) in a limited number of copies for the authors' use.

"This paper reports the results of a study in which 150 psychoneurotic patients ... were tested . . . before and after an interval of time during which some of them received psychotherapy and some of them did not." This frequently cited paper showed that therapy patients "did not improve significantly more" than those who did not receive therapy.

\section{AA14 A METHODOLOGY FOR MEASURING PERSONALITY CHANGES IN PSYCHOTHERAPY}

First separate printing:

A METHODOLOGY FOR MEASURING PERSONALITY CHANGES IN/ PSYCHOTHERAPY/ TIMOTHY LEARY AND JOAN S. HARVEY/ Kaiser Foundation Hospitall Oakland 11, California (across upper margin above title:) Reprinted from JOURNAL OF CLINICAL PSYCHOLOGY, Vol. XII, No. 3, 123-132, April 1956

$93 / 4 \times 61 / 2$ in. Pp. 123-32.

123-32 text. Issued without wrappers; stapled.

Offprinted from journal article (C14) in a limited number of copies for the authors' use.

"Describes a method for measuring change in personality" before and after psychotherapy using "the interpersonal system of diagnosis which employs 16 interpersonal variations at four levels of personality. 
First separate printing:

A THEORY AND METHODOLOGY FOR/ MEASURING FANTASY AND IMAGINATIVE/ EXPRESSION/ By/ TIMOTHY LEARY/ Kaiser Foundation/ Reprinted from JOURNAL OF PERSONALITY/ Vol. 25, No. 2, December, 1956 (cover title)

$87 / 8 \times 6$ in. Pp. [161]-[176].

[161]-175 text; [176] blank.

Tan wrappers printed in black; stapled.

Offprinted from journal article (C15) in a limited number of copies for the author's use.

Presents "a theory of and measurement for dealing with imaginative preconscious behavior."

\section{AA16}

DIMENSIONS \& MEASURE OF . . . PSYCHOTHERAPY

1959

First separate printing:

The Dimensions and A Measure of the Process of/ Psychotherapy: A System for the Analysis of the Content of/ Clinical Evaluations and Patient-Therapist Verbalizations/ TIMOTHY LEARY, Ph.D., AND MERTON GILL, M.D./ Reprinted from Research in Psychotherapy. Proceedings of a Conference, Washington, D.C. ,/ April 9-12, 1958. Published 1959 by American Psychological Association, Washington, D.C.

$9 \times 6$ in. Pp. [1] 62-95 [1].

[1] title; 62-95 text; [1] blank.

Issued without wrappers; stapled. 
Offprinted from book article (B1) in a limited number of copies for the authors' use.

"This is a working paper, somewhat revised from the one presented at the Conference on Research in Psychotherapy sponsored by the American Psychological Association, April 10-12, 1958" (from footnote, p. 62). "Our own research goals were the development of a comprehensive set of the dimensions of psychotherapy and a quantitative measurement of the raw data of psychotherapy" (from the Summary, p. 94).

First appearance:

\section{[The Existential Transaction]}

$11 \times 8 \frac{1}{2}$ in. Approximately 120 leaves (printed on one side only).

Purple-ink mimeograph; stapled.

Not seen (information from author).

The first draft of this work was written in Florence, Italy in the spring of 1959, and helped Leary gain an appointment to the Harvard Center for Personality Research. "The book suggested new, humanist, methods for behavior change" (Flashbacks, p. 16). The final draft was completed in Cambridge, Mass. in early 1960 and (after it was almost lost in an accident) produced in an edition of not more than 100 copies at the Center for Research in Personality, Harvard University, Cambridge, Mass.

\section{AA18 THINKING, TALKING AND DOING}

\section{First appearance:}

\section{Thinking, Talking and Doing/ Timothy Leary}

$11 \times 81 / 2$ in. 11 leaves.

[1]-10 text, preceded by title; dated at end: September, 1960/ Cambridge, Massachusetts; [11] bibliography.

Purple-ink mimeograph; stapled.

This paper was presented at the annual meeting of the American Psychological Association in Chicago, September 1, 1960, in the Division 12 and Society for Projective Techniques Symposium under the title: The Role of Level III 
(Projective) Data in Prediction. It is cited under the latter title in American Psychologist 15, no. 7 (July 1950):388.

Not more than 100 copies mimeographed at the Center Research in Personality, Harvard University, Cambridge, Mass., in the summer of 1960 for distribution at the symposium.

"I now stand convinced of the need for a new science of behavior which aims to be more realistic and humanistic, which addresses itself with flexible concepts and methods and with a collaborative attitude to the unique and everchanging transactions of human life" (p. 1).

\section{AA19 \\ DIAGNOSIS AND TREATMENT OF PSYCHOTHERAPY RESEARCH} 1960

\section{First appearance:}

\section{[Diagnosis and Treatment of Psychotherapy Research]}

Paper presented at the annual meeting of the American Psychological Association in Chicago on September 2, 1960, in the Division 12 Symposium: The Outlook for Psychotherapy Research. Cited in: American Psychologist 15, no. 7 (July 1960):421. Cited in a 1962 mimeographed list of Leary's publications under the title, "New Developments in Psychotherapy." Not seen.

\section{First appearance:}

\section{Pilot Study Research Project at Concord Correctional Institute}

$11 \times 8 \frac{1}{2}$ in. 3 leaves.

[1]-3 text, preceded by title, and signed at end: Timothy Leary, Ph.D./ March 1, 1961.

Purple-ink mimeograph; stapled. Not more than 100 copies produced at the Center for Research in Personality, Harvard University, Cambridge, Mass., for departmental distribution.

Brief description of early results of "psilocybin therapy research program" with prison inmates. 

RESEARCH PROJECT

First appearance:

Progress Report/ Behavior Change Research Project, Concord Correctional Institute

$11 \times 81 / 2$ in. 3 leaves.

[1]-3 text, preceded by title, and signed at end: Timothy Leary, Ph.D./ June 1, 1961.

Purple-ink mimeograph; stapled. Not more than 100 copies produced at the Center for Research in Personality, Harvard University, Cambridge, Mass., for departmental distribution.

A follow-up to AA20, presenting the results of further psilocybin sessions with inmates, whose experiences have been generally positive.

AA22 TO FIND AND FOSTER THE CREATIVE

1961

First appearance:

TO FIND AND FOSTER THE CREATIVE/ A Report to the Rhode Island School of Design/ Its Administration and Faculty/ by/ Frank Barron, Ph.D., and Timothy Leary, Ph.D./ Harvard University/ (rubber-stamped date JUL 15 1961)

$11 \times 8 \frac{1}{2}$ in. 29 leaves.

[*] title; 1-27 text, including six full-page tables; [28] Recommendations.

Black-ink mimeograph. The copy examined is bound in protective wrappers, hole-punched for two brass clips; on the upper wrapper is a plain label with title typed in and authors' names added in manuscript. Not more than 100 copies produced at the Center for Research in Personality, Harvard University, Cambridge, Mass. for distribution to the audience.

The Rhode Island School of Design asked the authors to address the administration on the subject of psychological tests that could evaluate creativity in the processing of student applicants. 


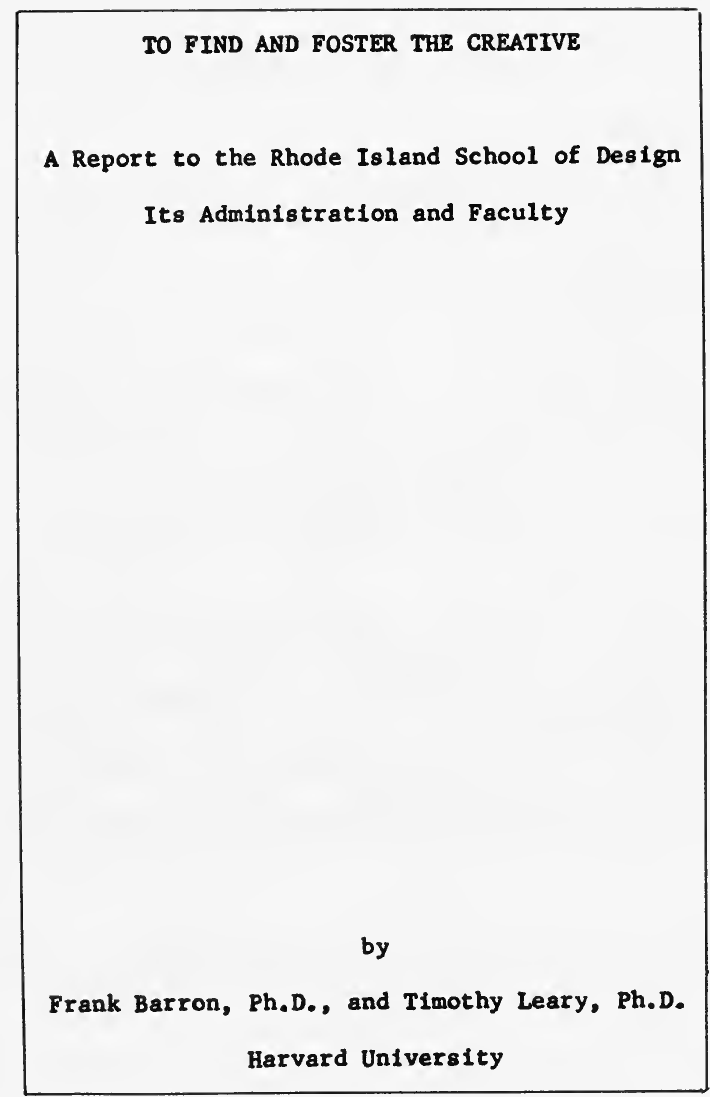

AA22: Only appearance (1961) of this Barron-Leary paper dealing with psychological testing for creativity. Courtesy Frank Barron.

a. First appearance:

HOW TO CHANGE BEHAVIOR/ Timothy Leary/ Harvard University/ Paper prepared for International Congress of Applied Psychology,/ Copenhagen, August, 1961

$11 \times 8 \frac{1}{2}$ in. 18 leaves.

[1]-17 text, preceded by title at head of p. [1]; eighteen footnotes. 


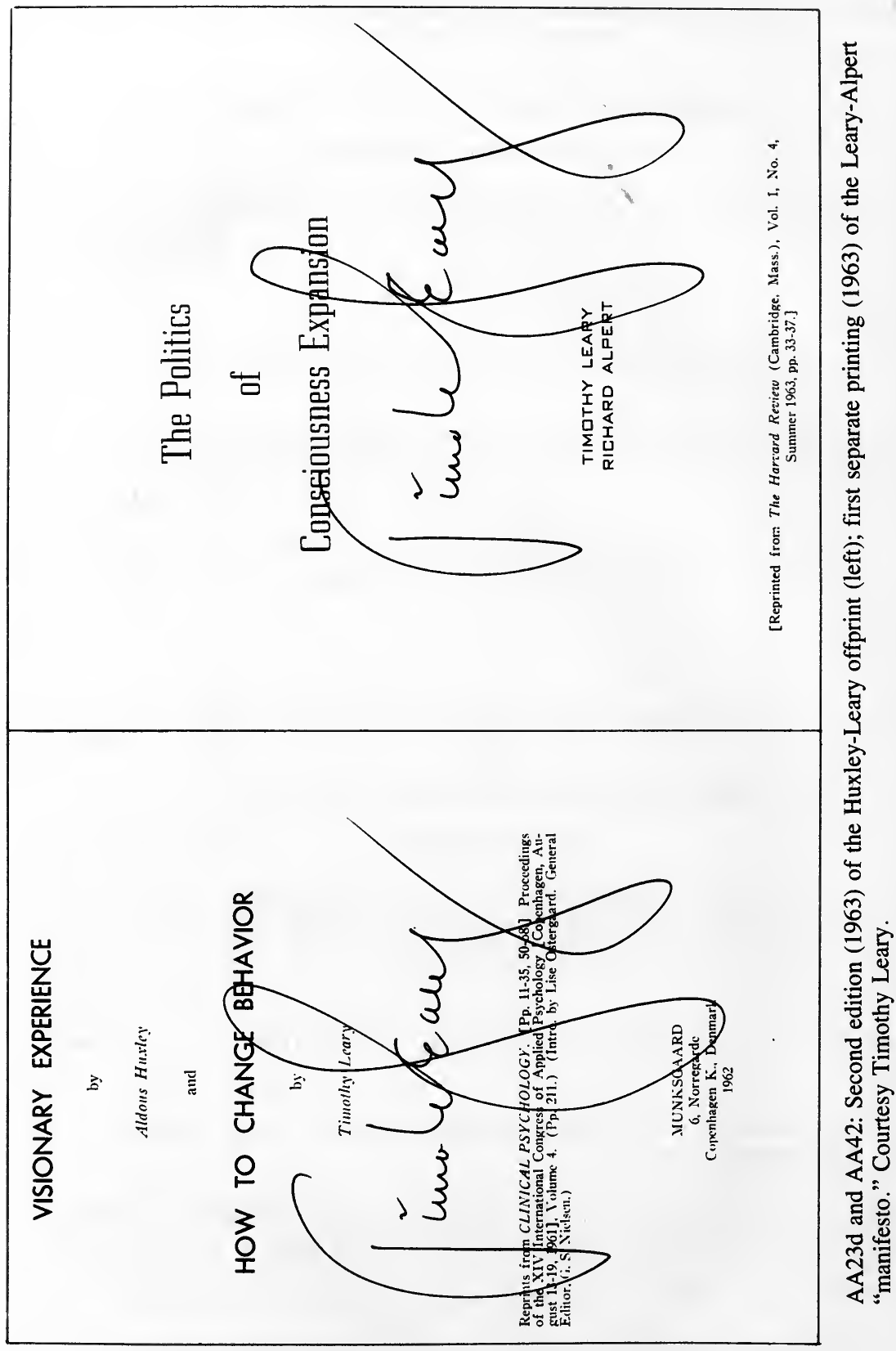


Purple-ink mimeograph; stapled.

Not more than 100 copies produced at the Center for Research in Personality, Harvard University, Cambridge, Mass., for distribution by the author during the summer of 1961 .

This is the first version of the talk delivered at the Copenhagen conference, and later published in the volume of the proceedings (B2). The text is identical, except that in this version there is a footnote added on p. [1]: The empirical data reported in this paper was assembled by George Litwin, Harvard University.

\section{b. Second appearance:}

HOW TO CHANGE BEHAVIOR/ Timothy Leary/ Harvard University

$11 \times 8 \frac{1}{2}$ in. 12 leaves. Undated.

[1]-12 text, preceded by title on p. [1].

Purple-ink mimeograph; stapled.

Not more than 100 copies produced at the Center for Research in Personality, Harvard University, Cambridge, Mass., for distribution by the author in late 1961 or early 1962 .

Footnote on p. [1]: Revision of a paper prepared for the XIV International Congress of Applied Psychology, Copenhagen, August 1961.

This revision is the basis of the expanded version of this address which appeared in offprint form in 1962 (AA23d).

c. First separate printing:

VISIONARY EXPERIENCE/ by/ Aldous Huxley/ and/ HOW TO CHANGE BEHAVIOR/ by/ Timothy Leary/ Reprints from Gerhard S. Nielsen (Ed.) Clinical Psychology./ Proceedings of the XIV International Congress of Applied Psychology, volume 4./ Copenhagen: Munksgaard, 1962, 211 p./ MUNKSGAARD/ (thin rule)/ 1962 (cover title)

$77 / 8 \times 47 / 8$ in. Pp. $11-35,50-68$.

11-35 text of Huxley address; 50-68 text of Leary address. 
White wrappers printed in black; stapled. Title printed on front cover, as above; back cover, near bottom: PRINTED IN DENMARK BY AARHUUS STIFTSBOGTRYKKERIE.

Offprint from Clinical Psychology (B2). Probably issued in a limited number of copies for the authors' use.

\section{d. Second separate printing:}

VISIONARY EXPERIENCE/ by/ Aldous Huxley/ and/ HOW TO CHANGE BEHAVIOR/ by/ Timothy Leary/ Reprints from CLINICAL PSYCHOLOGY. (Pp. 11-35, 50-68.) Proceedings/ of the XIV International Congress of Applied Psychology [Copenhagen, Au-/ gust 13-19, 1961], Volume 4 (pp. 211.) (Intro. by Lise Ostergaard. General/ Editor, G.S. Nielsen.)/ MUNKSGAARD/ 6, Norregarde/ Copenhagen K., Denmark/ 1962 (cover title)

$9 \times 6$ in. Pp. [1]-39 [1].

[1] title; [2] blank; 3-22 text of Huxley address; 23-37 text of Leary address; 38-39 footnotes to both addresses; [40] blank.

White self-wrappers printed in black, stapled.

Offprint, revised, of the first book appearance of this talk (B2). Approximately 100 copies printed for distribution to members of the International Federation for Internal Freedom in 1963. See BB2 for reprint of this version in book form.

Note on p. 37: These chapters are reprinted with slight revision and expanded footnotes.-IFIF, Reprint Division, Cambridge 38, Mass. The footnotes have been expanded from 2 to 13; one footnote cites an article published in winter 1963.

The XIV International Conference of Applied Psychology took place in Copenhagen, Aug. 13-19, 1961. In addition to Leary, Frank Barron of the Harvard psychology department and author Aldous Huxley were also invited to speak. This was the first and only time Huxley and Leary lectured together. Huxley's lecture was entitled "Visionary Experience"; it was delivered earlier than Leary's, and concludes with a reference to Leary's upcoming lecture ("We shall hear from Dr. Leary about the induction of such experiences by such substances as psilocybin"). Barron's talk contains the first reference in print to his "commend[ing] the mushroom to the attention of Dr. Leary, who immediately seized upon its possibilities as a vehicle for inducing change in behavior as a result of the altered state of consciousness which the drug produced." "How to Change Behavior" proved to be one of Leary's most popular addresses; it was reprinted in a number of books and journals, usually in the revised form of the offprint. 
First printing:

[Drugs, Set and Suggestibility]

Paper presented at the annual meeting of the American Psychological Association in New York on September 6, 1961, at a Divisions 1 and 10 Symposium: The Alteration of Perceptual Consciousness by Drugs. The meeting was chaired by Abraham Maslow. Participants were Frank Barron, Alan Watts, Timothy Leary. Discussants were William Burroughs and Maslow. Cited in American Psychologist 16 (July 1961):456. Later cited in the bibliography at the end of High Priest (1968) under the title: "Drugs, Set and Suggestion." Not seen.

This is apparently the first public report on the concept of "drug, set and setting" more fully developed in The Psychedelic Experience (A4).

First printing:

Helping the Helpless/ Timothy Leary

$11 \times 8 \frac{1}{2}$ in. 9 leaves.

[1]-9 text.

Purple-ink mimeograph; stapled.

Not more than 100 copies produced at the Center for Research in Personality, Harvard University, Cambridge, Mass. in the summer of 1961 for distribution at the conference.

At foot of p. [1]: "An address presented at the Northeast Regional Conference of the American Public Welfare Association, Boston, September 1961." A 1962 mimeographed checklist of Leary's publications cites this paper under a variant title with a slightly different date, as follows: "The Use of Group Methods with Children in Foster Care, Northeast Regional Conference of the American Public Welfare Association, August 24, 1961."

"For the past couple of years a group of psychologists at Harvard have been conducting exploratory studies in behavior change. We have deliberately attempted to avoid the expert role and we have explored the methods of collaboration of sharing power and responsibility with our clients" (p. 2). 


\section{HARVARD REHABILITATION PROGRAM}

\section{First appearance:}

Harvard Rehabilitation Program: Massachusetts Correctional Institution, Concord/ Progress Report, October 1961

$11 \times 8 \frac{1}{2}$ in. 3 leaves.

[1]-3 text, preceded by title, and signed at end: Timothy Leary, Ph.D./ Harvard University/October 15, 1961.

Purple-ink mimeograph; stapled.

Not more than 100 copies produced at the Center for Research in Personality, Harvard University, Cambridge, Mass., for departmental distribution.

Follow-up report to AA20 and AA21, being a summary of the Concord Prison Psilocybin Project up to that time.

\section{BEHAVIOR CHANGE RESEARCH PROGRAM}

\section{First appearance:}

PROGRESS REPORT/ Behavior Change Research Program-Concord Correctional Institution/ December, 1961, Center for Research in Personality Harvard University

$11 \times 8 \frac{1}{2}$ in. 2 leaves.

[1]-2 text, preceded by title and signed at end: Timothy Leary/ 12/7/61.

Purple-ink mimeograph; stapled.

Not more than 100 copies produced at the Center for Research in Personality, Harvard University, Cambridge, Mass., for departmental distribution.

Follow-up report to AA20, AA21, and AA26, on the status of the inmates who took psilocybin. 


\section{First appearance:}

\section{PROGRAM FOR TRAINING IN CREATIVITY}

$11 \times 8^{1 / 2}$ in. 3 leaves.

[1]-3 text, preceded by title, and signed at end: Timothy Leary, Ph.D./ Center for Research in Personality, Harvard University/ 1/26/62.

Purple-ink mimeograph; stapled.

Not more than 100 copies produced at the Center for Research in Personality, Harvard University, Cambridge, Mass. for departmental distribution. Follow-up report to Barron and Leary, "To Find and Foster the Creative" (AA22). AND BEHAVIORISM

First printing:

INTERPERSONAL BEHAVIOR AND BEHAVIORISM/ Timothy Leary/ Harvard University

$11 \times 8 \frac{1}{2}$ in. 12 leaves.

[1]-11 text; [12] bibliography.

Purple-ink mimeograph; stapled.

Footnote on p. 2: "This paper was read at a conference on Chemotherapy Studies in Psychiatry and Broad Research Approaches to Mental Illness, sponsored by the Veterans Administration. The symposium was held in Cincinnati, Ohio March 27, 1962." The paper was not published in the volume of the conference Transactions.

Not more than 100 copies produced at the Center for Research in Personality, Harvard University, Cambridge, Mass., in March 1962 for distribution at the conference.

"During the past two years in Cambridge, Massachusetts, a group of psychologists have been developing methods for describing and changing consciousness on 
the one hand and behavior on the other. Our studies of internal experience have involved consciousness-expanding drugs. We are constructing crude diagrams and linguistic guideposts for charting those internal realms for which we have no maps" (p. [1]).

First appearance:

Session \#16 - Zi./ Subject \#1/ Tim Leary

$11 \times 8 \frac{1}{2}$ in. 4 leaves. Undated.

[1]-4 text, preceded by title.

Purple-ink mimeograph; stapled.

Not more than 100 copies produced at the Center for Research in Personality, Harvard University, Cambridge, Mass., about September 1962. Description of a mescaline experience of Leary in Zihuatenejo, Mex. in summer of 1962, mimeographed shortly thereafter (dates supplied by author).

\section{AA31 LOS EFFECTOS PSYCHOTERAPEUTICOS 1962}

\section{First appearance:}

[Los Effectos Psychoterapeuticos de las Drogas Hallucinogenas]

Coauthored with Richard Alpert.

Paper read at meeting of the Mexican Society of Neurology and Psychiatry, Mexico City, Aug. 1962. Cited in bibliography at the end of High Priest (1968).

Not seen.

[1] text (unsigned; date supplied by author). 
No more than 100 copies produced at the Center for Research in Personality, Harvard University, Cambridge, Mass., about November 1962, for distribution to the audience.

Brief description of the research performed by the Harvard Psychedelic Research Project between 1960 and 1962. Los Angeles is described as a city which "leads the world in the use and abuse of consciousness-expanding drugs." The Harvard researchers "hope to profit from your mistakes and . . a achievements."

\section{First appearance:}

\section{DMT REPORT}

$11 \times 8 \frac{1}{2}$ in. 2 leaves.

[1]-2 text, preceded by title, signed and dated at end: T.L./ December 10, 1962.

Purple-ink mimeograph; stapled.

Not more than 100 copies produced at the Center for Research in Personality, Harvard University, Cambridge, Mass., December 1962, for research evaluation.

Description of an experience with the drug DMT.

\section{AA34 \\ AMERICANS \& MUSHROOMS}

1962

\section{First appearance:}

AMERICANS AND MUSHROOMS IN A NATURALISTIC ENVIRONMENT:/ A Preliminary Report/ Timothy Leary/ George Littwin and Ralph Metzner/ Harvard University

$11 \times 8 \frac{1}{2}$ in. 10 leaves. Undated.

[1]-10 text, preceded by title at head of p. [1].

Purple-ink mimeograph; stapled.

Apparently the earliest paper on the research conducted by the Harvard Psilocybin Project. One hundred seventy-five subjects participated in this "first naturalistic 
study." Results are determined from questionnaires. "The majority of our volunteer subjects report pleasant, educational, and even life-changing experiences."

Not more than 100 copies produced at the Center for Research in Personality, Harvard University, Cambridge, Mass., for authors' distribution in 1962. Cited in: Wasson, "Hallucinogenic Mushrooms . . Psilocybin” (1963), no. 253.

First appearance:

MEASURING VERBAL INTERACTION/ IN FREUDIAN AND ROGERIAN PSYCHOTHERAPY/ Timothy Leary/ Harvard University

$11 \times 8 \frac{1}{2}$ in. 77 leaves.

[1]-77 text and bibliography.

Purple-ink mimeograph; stapled.

Note at foot of p. [1]: Final version helped by advice from Richard Alpert, Ralph Metzner et al.

Not more than 100 copies produced at the Center for Research in Personality, Harvard University, Cambridge, Mass., for author's distribution in 1962.

AA36 EFFECTS OF TEST SCORE FEEDBACK

\section{a. First appearance:}

THE EFFECTS OF TEST SCORE FEEDBACK ON CREATIVE PERFORMANCE/ AND OF DRUGS ON CREATIVE EXPERIENCE/ By/ Timothy Leary/ Harvard University

$11 \times 8^{1 / 2}$ in. 39 leaves. Undated.

[1]-37 text, preceded by title; [38-9] references.

Purple-ink mimeograph; stapled.

Not more than 100 copies produced at the Center for Research in Personality, Harvard University, Cambridge, Mass., for distribution at the 5th Utah Creativity Research Conference held in Brighton, Utah in 1962. 


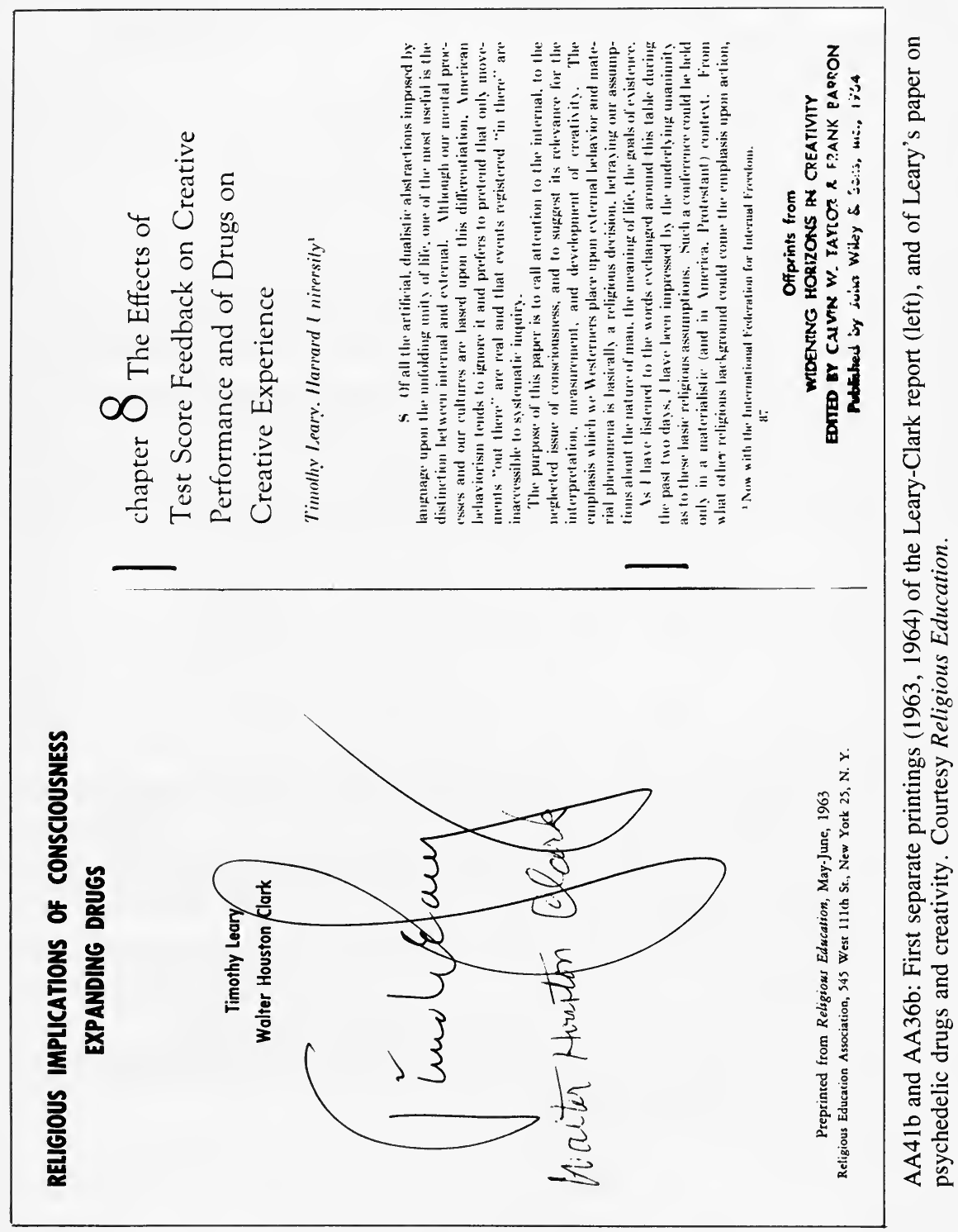




\section{b. First separate appearance in print:}

chapter 8 The Effects of/ Test Score Feedback on Creative/ Performance and of Drugs on/ Creative Experience/ Timothy Leary, Harvard University/ (stamped at bottom of page:) Offprints from/ WIDENING HORIZONS IN CREATIVITY/ EDITED BY CALVIN W. TAYLOR \& FRANK BARRON/ PUBLISHED BY JOHN WILEY \& SONS, INC., 1964 (cover title)

$9 \times 53 / 4$ in. Pp. 87-111.

$87-111$ text, with two figures.

Unbound; stapled.

Offprinted from chapter 8 of Widening Horizons in Creativity (B7) in a limited number of copies for the author's use.

The author is identified as "now with the International Federation for Internal Freedom." The book in which this chapter appears is a record of the proceedings of the 5th Utah Creativity Research Conference held two years earlier. "The purpose of this paper is to call attention to the internal, to the neglected issue of consciousness, and to suggest its relevance for the interpretation, measurement, and development of creativity."

\section{AA37 FREEDOM CENTER INCORPORATED}

First appearance:

FREEDOM CENTER INCORPORATED

$11 \times 81 / 2$ in. 9 leaves.

[1]-9 text, preceded by title and signed at end: Timothy Leary, Ph.D./ President, Freedom Center, Inc./ Jan. 15, 1963.

Purple-ink mimeograph; stapled.

Not more than 100 copies produced at the headquarters of Freedom Center, Cambridge, Mass., in January 1963 for distribution by the organization.

Report on the two-year prisoner rehabilitation project at Concord Prison, Mass., by the Harvard Psychedelic Research Project. Freedom Center operated a post-release rehabilitation program for former inmates and acted as consultants to those running the prison project. 


\section{STATEMENT OF PURPOSE \\ OF THE INTERNATIONAL \\ FEDERATION FOR INTERNAL FREEDOM}

First printing:

Statement of Purpose of the/ INTERNATIONAL FEDERATION/ FOR/ INTERNAL FREEDOM

Coauthored with Huston Smith.

$9 \times 6$ in. 4 pp.

[1-4] text, preceded by title.

Folded leaf.

Unknown number of copies printed in Cambridge, Mass. on Jan. 24, 1963 for distribution by the organization.

Description of the underlying situation in which the organization was formed as a nonprofit corporation; lists officers and functions. "This statement was prepared and distributed by the Chartered Board of Directors of IFIF." Besides Leary, the directors included Richard Alpert, Walter Clark, Rolf von Eckartsberg, Paul A. Lee, George Litwin, Ralph Metzner, Huston Smith, Gunther Weil and Alan Watts.

\section{AA39 PROBLEMS OF EXPANDING CONSCIOUSNESS 1963}

First printing:

PROBLEMS OF EXPANDING CONSCIOUSNESS/ An interview with research psychologist Dr. Timothy Leary, former head/ of Harvard University's research program into the effects of hallu-/ cinogenic or "consciousness-expanding" drugs. The interview, conduc-/ ted by Fred Haines, was first broadcast by Pacifica Radio in Los Angeles, / KPFK, on April 18, 1963.

$11 \times 81 / 2$ in. 13 leaves.

[1]-13 text, preceded by title. 
Mimeographed; unbound.

100 copies were printed and sold @ \$0.50 via radio advertising.

An unedited transcript of Leary's radio interview shortly after he left the psychology department at Harvard. He discusses how he became involved in psychedelic drug research, and the implications LSD has for our culture.

AA40

THE INDIVIDUAL IN

1963 THE COLLEGE COMMUNITY

\section{First appearance:}

The Individual in the College Community:/ His Commitments and His Work/ an address/ by/ Timothy Leary/ at/ The Second Annual Symposium on American Values/ Central Washington State College/ Ellensburg, Washington/ 24-27 April, 1963/ All rights reserved by/ Central Washington State College

$11 \times 8 \frac{1}{2}$ in. [ii] 18 leaves.

[i] title; [1]-18 text. At foot of p. [1]: This paper was delivered from notes as a talk not as a prepared address to be read.

Purple-ink mimeograph; stapled.

Transcribed from Leary's talk and mimeographed in a limited number of copies at Central Washington State College in Apr. 1963, for distribution at the symposium.

Reprinted in revised form under title, "American Education as an Addictive Process and Its Cure" in Politics of Ecstasy (A8), where it is noted that "one week following the lecture, the speaker was fired from Harvard University." Reprinted with slight revisions in A College Looks at American Values (BB7).

"The last thing that an institution of education wants to allow you to do is to expand your consciousness. . . . I also would like to suggest that our educational process is an especially dangerous narcotic because it probably does direct physiological damage to your nervous system." 
a. First appearance:

RELIGIOUS IMPLICATIONS OF CONSCIOUSNESS EXPANDING SUBSTANCES/ (at left:) Timothy Leary/ Harvard University (at right:) Walter Houston Clark/ Andover Newton Theological School

$11 \times 8 \frac{1}{2}$ in. 16 leaves.

[1]-15 text, preceded by title; sixteen references.

Purple-ink mimeograph; stapled. Undated.

Not more than 100 copies produced at the Center for Research in Personality, Harvard University, Cambridge, Mass., in early 1963 (prior to May) for the authors' distribution.

The first two sections (Introduction; Rehabilitation for the Prison Inmates, pp. 1-9) were written by Leary. The second section discusses the prison project at the Massachusetts Correctional Institution at Concord in which psilocybin was given to prisoners. The final section of commentary (pp. 10-15) was written by Dr. Clark of the Andover (Mass.) Newton Theological School.

b. First separate appearance in print:

RELIGIOUS IMPLICATION OF CONSCIOUSNESS/ EXPANDING DRUGS/ Timothy Leary/ Walter Houston Clark/ Preprinted from Religious Education, May-June 1963/ Religious Education Association, 545 West 111 th St., New York 25, N.Y. (cover title)

$93 / 8 \times 61 / 2$ in. Pp. [2] 251-56.

[1] cover title; [2] blank; 251-56 text.

White self-wrappers printed in black; stapled.

Offprinted from journal article (C21) in a limited number of copies for the authors' use.

The text of this printing has been corrected, and the title slightly changed. 
First separate printing:

The Politics/ of/ Consciousness Expansion/ TIMOTHY LEARY/ RICHARD ALPERT/ [Reprinted from The Harvard Review (Cambridge, Mass.), Vol. I, No. 4,/ Summer 1963, pp. 33-37.]

$9 \times 6$ in. [8] pp.

[1] cover title; [2] blank; [3-7] text; [8] blank.

White self-wrappers printed in black; stapled.

Offprinted from journal article (C22) in a limited number of copies for the authors' use in the summer of 1963. Reprinted in slightly revised form in The Politics of Ecstasy (A8) under the title, "The Fifth Freedom—The Right to Get High."

"Make no mistake: the effect of consciousness-expanding drugs will be to transform our concepts of human nature, of human potentialities, of existence. The game is about to be changed, ladies and gentlemen. Man is about to make use of that fabulous electrical network he carries around in his skull. . . . Head for the hills, or prepare your intellectual craft to flow with the current." This paper, as much as any text, served as a manifesto for the psychedelic movement; it appeared in print shortly after the authors left their posts at Harvard under great controversy.

First appearance:

THE RELIGIOUS EXPERIENCE: ITS PRODUCTION AND INTERPRETATION/ by/ Timothy Leary, Ph.D.

$11 \times 8 \frac{1}{2}$ in. $18 \mathrm{pp}$.

[1]-17 text, preceded by title; [18] blank.

Black-ink mimeograph (printed on both sides); stapled.

Not more than 100 copies produced in Cambridge, Mass. in Aug. 1963 for distribution to those attending the lecture.

At bottom of p. [1]: [*Lecture delivered at a meeting of Lutheran psychologists and other interested professionals, sponsored by the Board of Theological 
Education, Lutheran Church in America, in conjunction with the 71st Annual Convention of the American Psychological Association, Philadelphia, Bellevue Stratford Hotel, Friday, August 30, 1963.].

This is the first appearance of this much reprinted lecture, in which the author discusses the religious aspects of the psychedelic experience, with reference to the "Good Friday" experiment and the Janiger study. This talk was printed in slightly revised form in Mystery, Magic, and Miracle (B30) and in greatly revised form in The Politics of Ecstasy (A8) as "The Seven Tongues of God." See also C30 and C31 for journal printings.

\section{AA44 A NEW BEHAVIOR CHANGE PROGRAM 1963}

\section{a. First appearance:}

A Change Program for Adult Offenders Using Psilocybin/ Timothy Leary, Ralph Metzner, Madison Presnell, Gunther Weil, Ralph Schwitzgebel, and Sara Kinne

$11 \times 8 \frac{1}{2}$ in. 42 leaves.

[1]-42 text, preceded by title.

Purple-ink mimeograph; stapled.

Not more than 100 copies produced at the Center for Research in Personality, Harvard University, Cambridge, Mass., in 1963 for the authors' use.

This is the earliest version of "A New Behavior Change Program Using Psilocybin," 1965 (see A44c).

\section{b. Second appearance:}

[A Change Program for Adult Offenders Using Psilocybin]

Not seen. Cited in the bibliography to Widening Horizons in Creativity (B8) as a publication with the following imprint: Cambridge: Psychedelic Review Service, 1963.

c. First separate appearance in print:

A NEW BEHAVIOR CHANGE PROGRAM USING PSILOCYBIN/ TIMOTHY LEARY, RALPH METZNER, MADISON PRESNELL, GUNTHER WEIL,/ RALPH 
SCHWITZGEBEL, AND SARA KINNE (preceded by:) Reprinted from/ PSYCHOTHERAPY: THEORY, RESEARCH AND PRACTICE/Vol. 2, No. 2, July, 1965

$10 \times 65 / 8$ in. Pp. $61-72$.

61-72 text, preceded by title.

Issued without covers; sheets stapled.

Offprinted from journal article (C33) in a limited number of copies for the authors' use.

"This paper describes the procedure and results of a new kind of behavior change or rehabilitation program." The authors conclude that through the use of psilocybin in therapy the recidivism rate of the prisoners significantly dropped.

This paper, a revised version of AA44a and AA44b, with an altered title, was completed prior to Dec. 1963 (from internal evidence) but not published until July 1965.

\section{AA45 REACTIONS TO PSILOCYBIN ADMINISTERED IN A SUPPORTIVE ENVIRONMENT}

First separate printing:

REACTIONS TO PSILOCYBIN ADMINISTERED IN/ A SUPPORTIVE ENVIRONMENT/ TIMOTHY LEARY, PH.D., GEORGE H. LITWIN, A.B. AND RALPH METZNER, PH.D. (at upper left preceding title:) Reprinted from THE JOURNAL OF NERVOUS AND MENTAL DISEASE/ Vol. 137, No. 6 December, 1963/ Copyright (C) 1963 by The Williams \& Wilkins Co./ Printed in U.S.A.

$10 \times 67 / 8$ in. Pp. 561-73 [3].

$561-73$ text, preceded by title; [3, blank].

Issued without wrappers; stapled.

Offprinted from journal article (C26) in a limited number of copies for the authors' use in December 1963.

Footnote on p. 561 gives authors' affiliation as the Center for Research in Personality, Harvard University. The authors express their gratitude to Sandoz Laboratories for supplying psilocybin. This was one of the key papers to come out of the Psychedelic Research Project, and the first study to examine the effects of psychedelic drugs given in a supportive setting. 
First separate printing:

LANGUAGES:/ ENERGY SYSTEMS/ SENT AND RECEIVED/ Timothy Leary

$71 / 4 \times$ x 43/8 in. Pp. 431-60.

431-60 text, preceded by title.

Issued without covers; stapled.

Offprinted from journal article (C35) in a limited number of copies for the author's use.

About life as a linguistic system, consciousness as the decoding of energy, the nature of imprinting and reimprinting, and the new language of transcendental art (Tranart).

\section{AA47 PLAYBOY INTERVIEW: TIMOTHY LEARY 1966}

First separate printing:

PLAYBOY INTERVIEW: TIMOTHY LEARY/ a candid conversation with the controversial ex-harvard professor, prime partisan and prophet of LSD

$11 \times 8 \frac{1}{2}$ in. [12] pp.

[1-12] text, preceded by title; at end: "Reprinted from the September 1966 issue of PLAYBOY magazine;/ Copyright (C) 1966 by HMH Publishing Co., Inc.” Three photographs of Leary at the foot of p. [1].

Issued without covers; stapled.

Offprinted from magazine article (D1) in a limited number of copies in September 1966 for the author's use.

The author's first in-depth interview in a mass-market magazine proved highly controversial for its discussion of the sexual aspects of LSD. Reprinted in Politics of Ecstasy (A8); Drugs and Sexuality (BB10) as "She Comes In Colors"; and The Playboy Interview (B15). 


\section{AA48 A TRIBUTE TO JACKIE CASSEN, RUDI STERN 1966}

First appearance:

A TRIBUTE TO/ JACKIE CASSEN/ RUDI STERN/ by Timothy Leary and the League

$14 \times 8 \frac{1}{2}$ in. Printed from IBM selectric type on one side of a theater program.

Fifty-one-line statement on the psychedelic performance art of Cassen and Stern who provided the "synchronized cinema" projection for the League of Spiritual Discovery presentation, Psychedelic Celebration \#2: The Reincarnation of Jesus Christ," as well as two other performances (Celebrations \#1 and \#3) held at the Village Theatre in New York City in Sept. 1966. Leary also discusses the aim and the techniques of psychedelic artists in general.

AA49 THE PSYCHEDELIC
EXPERIENCE (READINGS ... )

First printing:

THE PSYCHEDELIC EXPERIENCE/ Readings from the book "The Psychedelic Experience: A Manual Based on the Tibetan Book of the Dead"/ By Timothy Leary, Ph.D.,/ Ralph Metzner, Ph.D. and Richard Alpert, Ph.D. (at top: BROADSIDE RECORDS Album No. BRX 601/ (C) 1966 by Broadside Records, 701 Seventh Ave., New York, N.Y. 10036

$11 \times 83 / 4$ in. 4 pp. (leaflet folded once).

[1] title and first page of text; $2-4$ continuation of text.

Descriptive notes issued with the long-playing record, The Psychedelic Experience $(\mathrm{F} 3)$ and placed inside the sleeve. The authors have adapted these notes from the essential information provided in their book, The Psychedelic Experience (A4) published two years earlier. They conclude: "We dedicate this recording to the many men and women whose accounts and reports of their explorations in the interior universe have helped us prepare these maps."

Second printing: (p. 1, at top:) FL 9701. 
First printing:

[untitled broadside, containing ten-line text by Leary beginning:] You can be anything you want to be

$71 / 8 \times 53 / 4$ in. One leaf.

[1] quotations from texts by Hermann Hesse and Timothy Leary, with their names printed in italic beneath each quote.

Printed in black on cream-colored, laid paper (portion of a watermark visible).

A few copies printed in 1969 for the author's use.

The Hesse quotation concerns God as "perfect being." The Leary quotation is a version of a verse from the phonograph record You Can Be Anyone This Time Around (F8), released in 1970.

According to the author, "this was a broadside printed as legal justification for getting fake 'I.D.' [It was] to be produced in court if [I were] later arrested." 


\section{B.}

\section{Books with Contributions}

First edition:

RESEARCH/ IN/ PSYCHOTHERAPY/ (rule)/ Proceedings of a Conference,/ Washington, D. C., April 9-12, 1958/ Eli A. Rubinstein/ Morris B. Parloff, Editors/ (rule)/ (ten lines of data on financing, sponsoring, planning and programming of conference)

$9 \times 6$ in. [2] viii, 294 pp.

[1] half-title; [2] blank; [i] title; [ii] Copyright 1959 by the/ AMERICAN PSYCHOLOGICAL ASSOCIATION, INC./ 1333 Sixteenth St., N.W./ Washington, D.C./ (short rule)/ (three lines pertaining to reproduction rights)/ Library of Congress Catalog Number 59-9192/ PRINTED BY THE NATIONAL PUBLISHING CO., WASHINGTON, D.C.; iii-iv Table of Contents; v-vi Preface; vii-viii Participants and Guests of the Conference; 1-293 text; [294] blank.

Light gray cloth lettered in blue. Front cover: RESEARCH/ IN/ PSYCHOTHERAPY/ (double rule). Back cover blank. Spine: (printed vertically:) RESEARCH IN PSYCHOTHERAPY/ (horizontally:) device of American Psychological Association)/ A.P.A. Endpapers white. Probably issued without dust jacket.

Published 1959@ @3.00. Unknown number of copies printed. Reprinted in 1969.

Contains "The Dimensions and A Measure of the Process of Psychotherapy: A System for the Analysis of the Content of Clinical Evaluations and Patient-Therapist Verbalizations," by Leary and Merton Gill, pp. 62-95, its first appearance in print. 
In the list of participants on p. vii, Leary is identified as "Director, Kaiser Foundation Psychology Research, Oakland, California." The conference was held under the auspices of the Division of Clinical Psychology of the American Psychological Association. The Leary and Gill paper was presented on Apr. 10, 1958.

See AA16 for offprint and descriptive note on this paper.

First edition:

CLINICAL PSYCHOLOGY/ Introduktion [sic] by/ Lise Ostergaard/ Rigshospitalet, Copenhagen, Denmark/ MUNKSGAARD/ (rule)/ 1962

$8 \times 5$ in. 211 pp.

[1] PROCEEDINGS OF/ THE XIV INTERNATIONAL CONGRESS/ OF APPLIED PSYCHOLOGY/ COPENHAGEN 1961/ VOLUME FOUR; [2] (13 lines of publication data pertaining to the five volumes published in the series); [3] title; [4] MUNKSGAARD/ International Booksellers and Publishers, Ltd./ 6, Nooregade, Copenhagen K., Denmark./ (C) 1962/ by MUNKSGAARD,/ Copenhagen, Denmark./ (4 lines in italic pertaining to rights of reproduction)/ Cover designed by IB JORGENSEN/ PRINTED IN DENMARK BY AARHUUS STIFTSBOGTRYKKERIE; [5] Foreword; [6] (16-line note giving particulars of the conference) [7] Table of Contents; [8] blank; 9-10 Introduction; 11-211 text; [212] blank.

Purple and pink cloth lettered in white, pink and purple. Front cover: clinical psychology/ PROCEEDINGS OF/ THE XIV INTERNATIONAL CONGRESS OF APPLIED PSYCHOLOGY/ VOLUME 4/ (rule)/ CONTRIBUTORS:/ (list of thirteen names in three lines)/ INTRODUCTION BY LISE OSTERGAARD/ MUNKSGAARD. Back cover: (list of titles of five volumes in series)/ (publisher's device). Spine (printed vertically:) CLINICAL PSYCHOLOGY. Endpapers white. Probably issued without dust jacket.

Published 1962. Unknown number of copies printed; price unknown.

Contains "How to Change Behavior," pp. 50-68. This is the first official publication of this paper, and its first publication in book form; see AA23c for the offprint. It was previously printed in mimeograph form (AA23b) and afterwards reprinted in LSD:The Consciousness-Expanding Drug (B4) with minor revisions. 


\section{a. First edition:}

(printed in black on white:) Alan W. Watts The Joyous Cosmology/ (printed in white on black:) ADVENTURES $\backslash$ IN THE CHEMISTRY/ OF CONSCIOUSNESS/ Foreword by Timothy Leary, Ph.D.,/ and Richard Alpert, Ph.D./ CENTER FOR RESEARCH IN PERSONALITY, HARVARD UNIVERSITY/ PANTHEON BOOKS

$93 / 8 \times 71 / 2$ in. $x x, 100 \mathrm{pp}$.

[i] half-title; [ii] blank; [iii] Also by Alan W. Watts/ (list of his fifteen previous books); [iv-v] double title-page; [vi] @ 1962 by Pantheon Books, / a Division of Random House, Inc., New York, N.Y.I Library of Congress Catalog Card Number: 62-10080/ (two lines referring to permission to reproduce)/Printed in the USA by Halliday Lithograph Corp., West Hanover, Mass./ Bound by $\mathrm{H}$. Wolff Book Mfg. Co., New York, N.Y./ Designed by Klaus Gemming; [vii] dedication ( To the people of Druid Heights); [viii] blank; ix-xv Foreword; [xvi] blank; xvii-xix Preface; [xx] blank; [1]-[80] text; [81]-[95] Epilogue; [96] blank; [97] Description of Plates; [98-100] blank.

Black cloth. Front cover blind-stamped: THE JOYOUS COSMOLOGY. Spine: (printed vertically in gilt:) WATTS (in black on gilt band:) THE JOYOUS COSMOLOGY (in gilt:) PANTHEON. Endpapers white. Dust jacket black and blue printed in white. Front panel: title and author printed over photograph of malva flower by Anton Stankowski. Back panel: photo of author by Loly Rosset. Spine: author, title, imprint.

Published June $1962 @ \$ 5.00 .8,576$ copies printed. Reprinted in 1966 with price raised to $\$ 6.95$; reprinted again in 1970 . Total sales $1962-1970$ were 12,091 copies.

Contains "Foreword" by Leary and Richard Alpert, pp. ix-xv, dated Harvard University, January, 1962. Leary and Alpert describe The Joyous Cosmology as "a brilliant arrangement of words describing experiences for which our language has no vocabulary," and "perhaps the best statement on the subject of space-age mysticism." They make reference to William James, Aldous Huxley and their own experiments conducted at Harvard. The book was published one month after they left that university.

b. First paperback edition:

Alan W. Watts The Joyous/ Cosmology/ (at left:) Foreword by Timothy Leary, Ph.D.,/ and Richard Alpert, Ph.D./ (at right:) ADVENTURES IN/ 


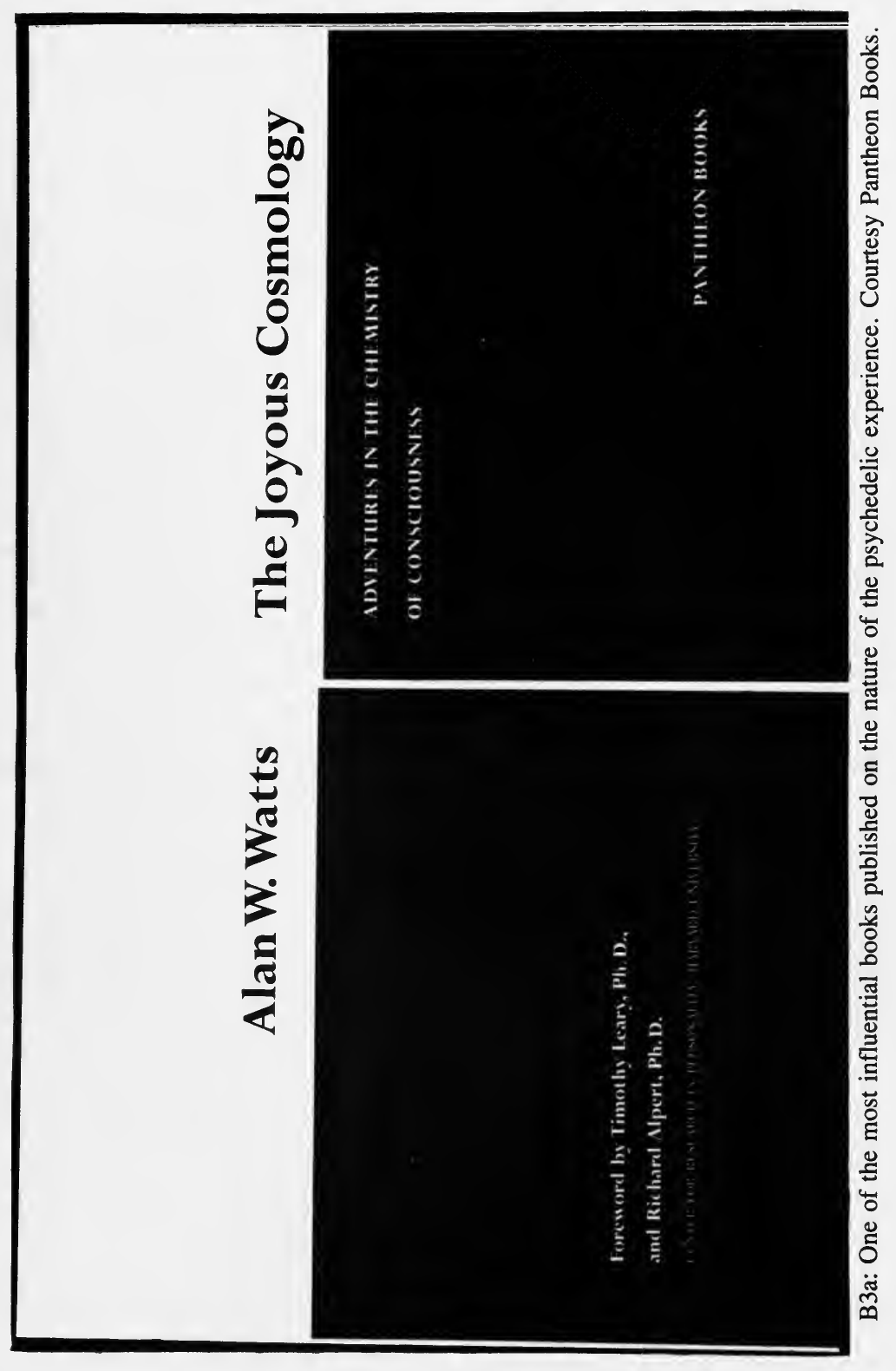



Books/ A DIVISION OF RANDOM NEW YORK

\author{
$8 \times 53 / 16$ in. $\times x, 108$ pp.
}

Reduced photo-offset printing of text of B3a, with variations in the preliminary leaves and at the end. Copyright page [iv], first line: FIRST VINTAGE EDITION, September, 1965. Blue, black and white wrappers printed in white and black. Front cover (with photograph of malva flower) closely resembles dust jacket of B3a; at bottom: A Vintage Giant (device) V-299 \$1.45. Publisher's blurb on back cover states: "Timothy Leary and Richard Alpert, formerly of the psychology department at Harvard University, have written the Foreword."

Published July 23, $1965 @ \$ 1.45 .5,662$ copies printed. There was a second paperback printing with the line "First Vintage Edition, September, 1965" deleted from the copyright page. A third paperback printing has the price raised to $\$ 1.65$ and a four-line quotation from a review on the front cover ("The classic book on the hallucinogenic drugs LSD, mescaline and psilocybin . . ."). A fourth paperback printing has an added copyright date of 1970 on p. [iv] and the price raised to \$1.95. Records of paperback sales show a total of 152,486 sold from 1965-1980.

\title{
a. First edition:
}

LSD The/ Consciousness-Expanding/ Drug/ DAVID SOLOMON, Editor/ Introduction by/ Timothy Leary, Ph.D./ G. P. Putnam's Sons/ New York/ (publisher's device to right of imprint)

$8 \frac{1 / 4}{4} 55 / 8$ in. xiv, $274 \mathrm{pp}$.

[i] half-title; [ii] blank; [iii] title; [iv] COPYRIGHT (C) 1964 by David Solomon/ (two lines pertaining to rights of reproduction)/ Library of Congress Catalog Card Number: 64-18016/ MANUFACTURED IN THE UNITED STATES OF AMERICA/ (thirty-six lines of copyright permissions); [v] Acknowledgments; [vi] blank; [vii] dedication (to Aldous Huxley); [viii] blank; ix-x Editor's Preface; xi-xii Contents; [xiii] fly-title; [xiv] blank; 1-266 Introduction and text; 267-273 Index; [274] blank.

Binding A: Red cloth spine, light brown board sides. Front cover board blind-stamped in lower right corner: LSD. Spine stamped in gilt: LSD/ (title printed vertically:) THE CONSCIOUSNESS-EXPANDING DRUG/ SOLOMON/ Putnam. Top edge unstained. Fore-edge untrimmed. Endpapers white. 
Binding B: Black cloth. Spine stamped identically in gilt and front cover in blind as in binding A. Top edge stained orange. Fore-edge untrimmed.

Binding A probably precedes, as later issues bearing the words "Second Impression" and "Third Impression" added above the first line of text on p. [iv] have been noted only in copies bound in black cloth.

Dust jacket printed in pink, orange, black and white. Front panel: "LSD" printed in large letters occupying top two-thirds of panel; below, subtitle, editor's name, "Introduction by Timothy Leary, Ph.D." and partial list of contributors. Back panel lists all of the contributors with their affiliations, with photograph and biographical information about the editor. Spine reproduces in type the cloth spine of the book.

Publisher's records lost due to flooding. Unknown number of copies published in $1964 @$ @5.95. Two further printings (designated “Second Impression” and "Third Impression") appeared after the first.

Contains "Introduction" (dated Millbrook, N.Y., May 1964), pp. 1-21, and "How to Change Behavior," pp. 97-113. First printing of the former, a lengthy discussion of the role of psychedelic drugs in our culture; reprint of "How to Change Behavior," as it originally appeared in Clinical Psychology (B2), except that the two footnotes now appear in the text, and the book reference is erroneously placed at the foot of the first page of text; other slight grammatical or sylistic changes noted which appear to be the editor's, not the author's.

\section{b. First paperback edition:}

\section{LSD:/ The/ Consciousness-Expanding/Drug/ Edited by DAVID SOLOMON/ Introduction by TIMOTHY LEARY, Ph.D./ (publisher's device)/ A BERKLEY MEDALLION BOOK/ Published by G. P. Putnam's Sons/ Distributed by Berkley Publishing Corporation}

$7 \times 4 \frac{1}{4}$ in. $x, 272$ pp.

Text unchanged from B4a. Copyright page [iv] reads in part: G. P. Putnam's-Berkley Medallion Edition,/ June, 1966.

White and red illustrated paper wrappers printed in red, black, blue, yellow and white. Color photograph of a distorted face on front cover. Edges stained red.

Published June $1966 @$ @0.95. Undisclosed number of copies printed. Berkley Medallion series no. N1277. There were six printings of this edition, with minor variations of p. [iv], primarily the designation of new printing and date. The sixth and last printing is dated Sept. 1968. Total number of copies printed is likely to have exceeded 250,000 . Some later printings have edges stained yellow.

"Introduction" occupies pp. 11-30 of this edition, "How To Change Behavior" pp. 103-18. 
First edition:

(text across facing pages:) Personality: Readings in Theory and Research/ edited by Eugene A. Southwell and Michael Merbaum/ The University of Chicago/ with the assistance of Jack Vognsen/Wadsworth Publishing Company, Inc./ Belmont, California

$9 \times 6$ in. $x, 438$ pp.

[i] half-title; [ii-iii] title; [iv] Cover etching by Helen Breger/ Personality: Readings in Theory and Research/ edited by Eugene A. Southwell and Michael Merbaum/ (C) 1964 by Wadsworth Publishing Company, Inc., Belmont, California/ (three lines pertaining to reproduction rights)/ L.C. Cat. Card No.: 64-21001/ Printed in the United States of America; v-vi Preface; vii-ix Contents; [x] blank; [1] fly-title; [2] blank; [3]-438 text.

Stiff, white paper wrappers with all-around abstract design of a group of people, text in black. Front cover: title above design, editor's names beneath. Back cover: cover credit above design, publisher's imprint beneath. Spine: (printed vertically:) personality/ readings in theory/ and research/ southwell/ and merbaum/ (horizontally): wadsworth.

Published $1964 @ \$ 6.00$. Undisclosed number of copies printed. CBI (1965) also cites a "text edition" selling for $\$ 4.50$.

Contains "Interpersonal Diagnosis" (full title: "Interpersonal Diagnosis: Some Problems of Methodology and Validation") by Leary and Hubert S. Coffey on pp. 73-96. This is the first book appearance of this paper. It originally appeared in J. Abnormal Social Psychology, 1955 (C11); see AA11 for the offprint and descriptive note. The text of the paper is the same in the book, except the title has been shortened and the acknowledgment of grant assistance has been omitted. There were six printings to Aug. 1968, at which point the publisher was Brooks/ Cole (a Division of Wadsworth Publishing Co.).

a. First edition:

(printed vertically:) Richard Blum \& Associates/ UTOPIATES/ The Use and Users of LSD 25/ Foreword by Nevitt Sanford 
$9 \times 6$ in. $x v i, 304$ pp.

[i] half-title; [ii] A Publication of/ the Institute for/ the Study of Human Problems/ Stanford University/ Nevitt Sanford, Director/ATHERTON PRESS/ New York, New York/ 1964; [iii] title; [iv] UTOPIATES/ The Use \& Users of LSD-25/ Richard Blum \& Associates/ Copyright (C) 1964 by Atherton Press/ (five lines referring to copyright and permission to reproduce)/Library of Congress Catalog Card Number 64-23746/ Printed in the United States of America 93974;/ [v] The Atherton Press/ Behavioral Science Series/ (list of previous titles); [vi]-vii Contents; [viii]-x Contributors; [xi]-xvi Foreword; [1]-293 text; [294] blank; [295]-303 Index; [304] blank.

Blue and green cloth. On front cover: publisher's device blind-stamped in bottom right corner. On spine, stamped in silver: BLUM \&/ ASSOCIATES/ (printed vertically:)/ UTOPIATES/ (horizontally:) ATHERTON. Endpapers white. Dust jacket white, printed in blue and green, with representation of poppy plant on front and back covers; lettering repeats content and style of title page and spine.

Published $1964 @ \$ 8.00$. Unknown number of copies printed (publishing records unavailable).

Contains "Rationale of the Mexican Psychedelic Training Center" by Leary, Richard Alpert and Ralph Metzner, pp. 178-86.

Description of the aims, purposes and results of the Psychedelic Training Center, which operated in Zihuatanejo, Mexico during the summers of 1962 and 1963. "The Mexican Center was the first . . . attempt to provide a series of guided psychedelic sessions for prepared volunteer subjects." Reference is made to the use of the Tibetan Book of the Dead and its translation into "psychedelic English" (see A4).

\section{b. First British edition:}

UTOPIATES/ The use and users of LSD 25/ RICHARD BLUM/ and associates/ Foreword by Nevitt Sanford/ (publisher's device)/ TAVISTOCK PUBLICATIONS

Bound from sheets of American edition (B6a), with new half-title and title page, and deleting pp. [iv-v] from that edition. Copyright page [iv] reads in part: First published in Great Britain in 1965/ by Tavistock Publications Limited/11 New Fetter Lane, London E.C. 4 .

Brown cloth, spine lettered in gilt. Top edge stained orange. Dust jacket pink, printed in black and white. Front panel drawing modelled on American jacket. 
First edition:

Widening Horizons/ in Creativity/ (rule)/ The Proceedings of the Fifth Utah/ Creativity Research Conference/ EDITED BY/Calvin W. Taylor/ Chairman of the Utah Conferences/ and Professor of Psychology/ University of Utah/ JOHN WILEY \& SONS, INC., NEW YORK • LONDON • SYDNEY

$9 \times 57 / 8$ in. $x x, 468 \mathrm{pp}$.

[i] half-title; [ii] blank; [iii] (five lines referencing the author's previous book); [iv] photo and names of participants in conference; [v] title; [vi] COPYRIGHT (C) 1964 by John Wiley \& Sons, Inc./ (three lines referring to permission to reproduce)/ Library of Congress Catalog Card Number: 64-25879/ PRINTED IN THE UNITED STATES OF AMERICA; [vii] dedication; [viii] blank; ix-xvi Preface; xvii-xix Contents; [xx] blank; [1]-466 text; pp. [467-68] blank.

Dark gray cloth stamped in orange and white on spine: (printed vertically:) Widening Horizons in Creatively/ (horizontally:) Edited by Taylor/ (device)/ WILEY. Endpapers white. Dust jacket green, white and blue, printed in gold and blue. On front cover: blue graphic image and title in gold. On back: blurb about another book by same author.

Published Nov. 30, $1964 @ \$ 8.95$. Undisclosed number of copies printed.

Contains "The Effects of Test Score Feedback on Creative Performance and of Drugs on Creative Experience," pp. 87-111, with two figures and two tables. See AA36 for offprint form and annotation.

\section{a. First edition:}

The/ Psychedelic/ Reader/ (decorative cut of lines radiating outward from dark center)/ Selected from The Psychedelic Review/ Edited by Gunther M. Weil,/ Ralph Metzner and Timothy Leary/ (rule thicker in middle)/ UNIVERSITY BOOKS (publisher's device) New Hyde Park, New York

93/16 x 6 in. xii, 260 pp.

[i] half-title; [ii] blank; [iii] title; [iv] COPYRIGHT (C) 1965 BY UNIVERSITY BOOKS, INC./ Library of Congress Catalogue Card Number: 65-24475/ Manu- 
factured in the United States of America; [v] Contents; [vi] blank; vii-[ix] Introduction by Gunther M. Weil; [x] blank; [xi] fly-title to section one; [xii] blank; 1-248 text; 249-260 Index.

Blue cloth stamped in silver. Front cover contains same cut as appears on title page. Spine: (printed vertically:) The Psychedelic Reader/ (horizontally:) (publisher's device)/ UNIVERSITY BOOKS. Red endpapers. Top edge stained dark blue. Dust jacket black and white, printed in blue, pink, black and white. Front of jacket prints title, subtitle and editors' names, ornament from title and partial list of authors and titles. Back panel prints ads for other books including The Psychedelic Experience.

Published June $1965 @ \$ 5.95 .5,000$ copies printed. Contains “Hermann Hesse: Poet of the Interior Journey," coauthored with Ralph Metzner, pp. 111-126, and "The Religious Experience: Its Production and Interpretation" pp. 191-213. Both originally appeared in Psychedelic Review (C24) and (C30).

"The articles which appear in this volume are the most important essays from the first four issues of Psychedelic Review" (from publisher's blurb on dust jacket).

\section{b. First paperback edition:}

The/ Psychedelic/ Reader/ (ornament as in B8a)/ Selected from The Psychedelic Review/ Edited by Gunther M. Weil,/ Ralph Metzner and Timothy Leary/ THE CITADEL PRESS, SECAUCUS, N.J.

$9 \times 6$ in. xii, 260 pp.

Photo-offset reprint of B8a, to which it collates identically, except for title (above) and p. [iv], which reads in part: First paperbound edition, 1971/ Published by Citadel Press, Inc./ A subsidiary of Lyle Stuart, Inc./ 222 Park Avenue South, New York, N.Y. 10003.

Stiff purple wrappers, with bands of yellow, orange and turquoise, printed in purple, white and orange. Published in $1971 @ \$ 3.95$. 3,500 copies printed. Citadel series no. C-334. Reprinted 1973 (second paperbound printing), with change in publisher's address to: 120 Enterprise Ave., Secaucus, N.J. 4,000 copies printed. Price raised to $\$ 4.95$.

First edition:

THE NARCOTIC REHABILITATION ACT OF 1966/ (double rule)/ HEARINGS/ BEFORE A/ SPECIAL SUBCOMMITTEE/ OF THE/ COMMITTEE ON THE JUDICIARY/ UNITED STATES SENATE/ EIGHTY-NINTH CONGRESS/ 


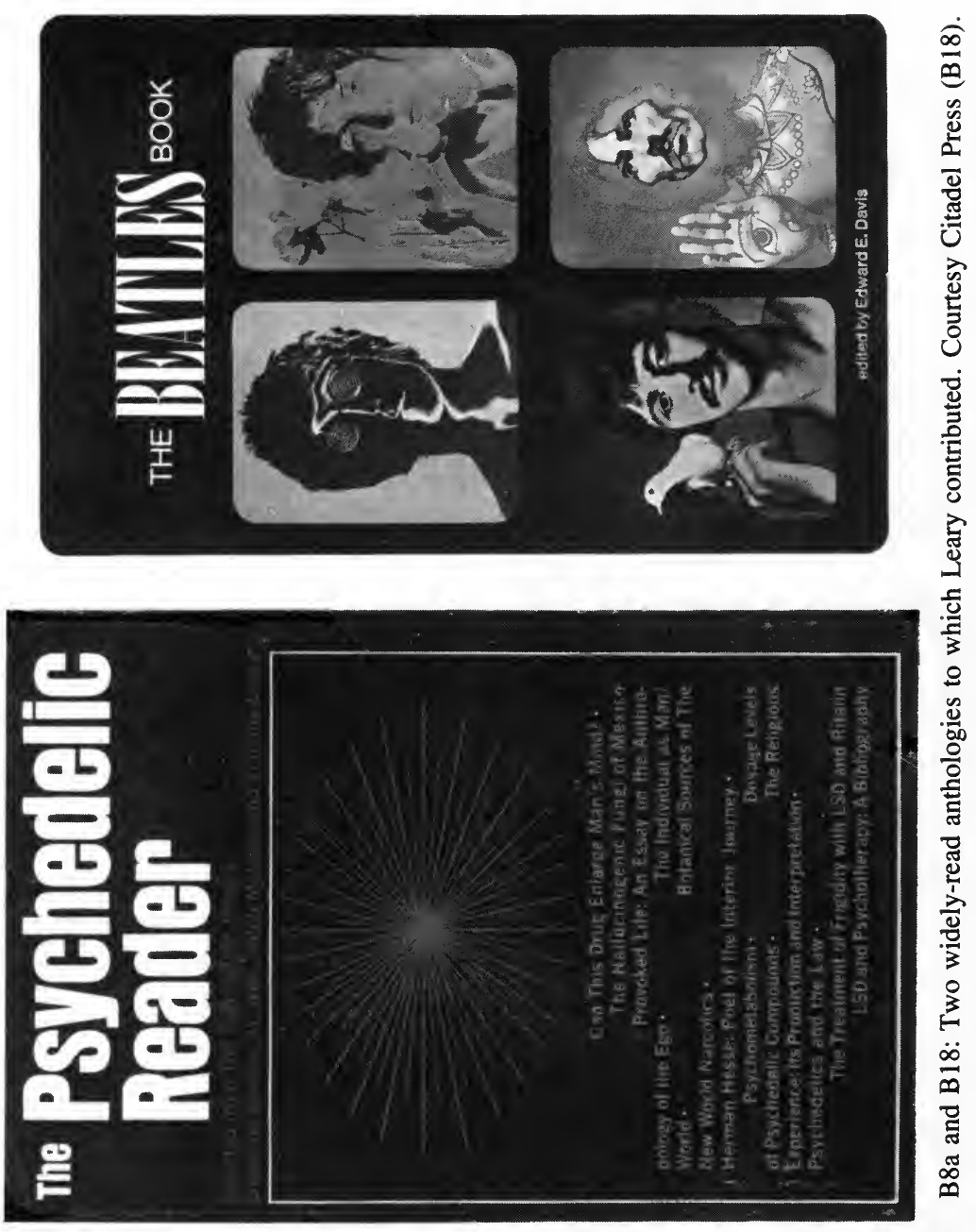


SECOND SESSION/ PURSUANT TO/ S. Res. 199/ EIGHTY-NINTH CONGRESS/ ON/ S. 2133, S. 2144, S. 2152/ AND/ LSD AND MARIHUANA USE ON COLLEGE CAMPUSES/ (single rule)/ JANUARY 25, 26, AND 27 , MAY 12, 13, 19, 23, AND 25, JUNE 14 AND 15,/ JULY 19, 1966/ (short rule)/ Printed for the use of the Committee on the Judiciary/ (device)/ U.S. GOVERNMENT PRINTING OFFICE/ WASHINGTON: 1966/ (at left) $66-668$

$91 / 8 \times 57 / 8$ in. VIII, 616 pp., with illustrations and charts in text.

(I) title; (II) list of members of the Committee on the Judiciary and the Special Subcommittee; III-VIII Contents; 1-616 text.

Green paper wrappers printed in black. Front cover: reproduces title page but omits publisher's imprint. Back cover blank. Spine: (printed vertically:) THE NARCOTIC REHABILITATION ACT OF 1966 (device) 1966.

Published in 1966 after July 19. Unknown number of copies for sale by the Government Printing Office.

"Statement of Timothy Leary, LSD Experimenter, Testifying on Behalf of the Castalia Foundation of Millbrook, N.Y." appears on pp. 239-58. Leary was questioned by Senator Thomas J. Dodd, Conn., chairman of the Special Subcommittee, and Senator Edward M. Kennedy, Mass., a member of that subcommittee. The statement is preceded on p. 238 by remarks of Sen. Dodd, welcoming Dr. Leary. The questioning is very wide ranging, with little agreement between Dr. Leary, who argued for licensed use of LSD and other psychedelic drugs, and the legislators. After these hearings, use of LSD was made illegal in the United States.

\section{First printing:}

Personality Research/ A Book of Readings/ EDITED BY/ DONN BYRNE/ University of Texas/ MARSHALL L. HAMILTON/San Jose State College/ Prentice-Hall, Inc. Englewood Cliffs, New Jersey

$9 \times 6$ in. [2] xiv, 416 pp.

[1-2] blank; [i] half-title; [ii] Prentice-Hall Psychology Series/ Richard S. Lazarus, Editor/ (five lines listing publisher's offices); [iii] title; [iv] @ 1966 by Prentice-Hall, Inc./ Englewood Cliffs, New Jersey/ (four lines referring to reproduction rights)/ Current printing (last digit):/ 1098765432 1/ Library of 
Congress Catalog Card Number: 66-20861/ PRINTED IN THE UNITED STATES OF AMERICA/ C-65796; v-vi Preface; vii-ix Contributors; [x] blank; xi-xiii Contents; [xiv] blank; [1] fly-title; [2] blank; 3-411 text; [412-16] blank.

Stiff red and gray wrappers printed in red, illustrated across both covers with watercolor drawing depicting groups of people. Front cover: PERSONALITY/ RESEARCH/ A Book of Readings/ edited by/ DONN BYRNE/ MARSHALL L. HAMILTON. Back cover: publisher's blurb and imprint. Spine: (printed vertically:) PERSONALITY RESEARCH/ A Book of Readings/ BYRNE \& HAMILTON/ (horizontally:) Prentice/ Hall.

Published $1966 @ \$ 5.50$. Undisclosed number of copies printed. A third edition was published in $1979 @ \$ 16.95$.

Contains "Changes in Psychoneurotic Patients With and Without Psychotherapy," coauthored with Frank Barron, pp. 192-200. Reprinted from J. Consulting Psychology (C13). Editor's note on pp. 190-91 emphasizes importance of paper.

\section{a. First edition:}

The/ Marihuana Papers/ Edited by David Solomon/ Introduction by Alfred R. Lindesmith, $\mathrm{PhD} /$ The Bobbs-Merrill Company, Inc./ A subsidiary of Howard W. Sams \& Co., Inc., Publishers/ Indianapolis • Kansas City • New York

$9 \times 6$ in. xxvi, 450 pp.

[i] half-title; [ii] (at lower left:) Previously edited by David Solomon/ LSD: The Consciousness-Expanding Drug (at right: illustration of a marijuana plant); [iii] title; [iv] Copyright (C) 1966 by David Solomon/ (two lines regarding reproduction rights)/ Library of Congress Catalog Card Number 66:25282/ Designed by Martin Stephen Moskof/ Printed in the United States of America; [v] dedication; [vi] blank; vii-viii Acknowledgments; ix-xi Contents; [xii] blank; xiii-xxi Editor's Foreword; [xxii] blank; xxiii-xxvi Introduction by Alfred R. Lindesmith; [1]-416 text; 417-38 Appendix; [439] illustration; [440] blank; 441-48 Index; [449-50] blank.

Green cloth stamped in gilt on spine: Edited by/ David Solomon/ (printed vertically:) THE/ MARIHUANA/ PAPERS/ (horizontally:) Bobbs-Merrill. Endpapers white. Dust jacket green, black and white, printed in white, orange and black. Rainbow-colored marijuana leaf on front cover; blurbs on back cover. Spine wording identical to cloth spine. 
Published Dec. $1966 @ \$ 10.00$. 5,000 copies printed. Second printing identical to first, published Mar.1967@ \$10.00.2,500 copies printed.

Contains "The Politics, Ethics, and Meaning of Marijuana," pp. 82-99. This is the first appearance of this essay, which includes, apart from the issues noted in the title, an outline of six levels of consciousness and the first printing of "The Two Commandments for the Molecular Age." This essay was later reprinted in Toward Social Change (BB6).

\section{b. First paperback edition:}

THE/ MARIHUANA/ PAPERS/ Edited by DAVID SOLOMON/ Introduction by Alfred R. Lindesmith, PhD/ (publisher's device)/ A SIGNET BOOK/ Published by The New American Library

$7 \times 43 / 16$ in. xxviii, [29]-512 pp.

Text unchanged from B11a. Pp. [510-12] contain ads. Copyright page [iv] reads in part: This is an authorized reprint of a hardcover edition/ published by The Bobbs-Merrill Company, Inc./ First Printing, April, 1968.

Stiff, glossy, white paper wrappers, printed in black, white, purple and red. Photograph of multicolored blurred lights on front cover and the words: Complete and Unabridged. Blurbs on front and back covers.

Published Apr. $1968 @ \$ 1.50 .97,685$ copies printed. Signet Book W3442. 2nd printing (for Canada): Apr. 1968. 5,295 copies@ @ $\$ 1.50 .3$ rd printing: Feb. 1969. 32,015 copies@ @1.50.4th printing: Mar.1970. 51,420 copies@ \$1.50.5th printing: Feb. 1971.48,770 copies@\$1.50. Total printed:235,185 copies.

The fifth printing has a new cover of yellow wrappers lettered in white, black and brown, without illustration, and is noted as Mentor Book MW1072. Leary's article occupies pp. $121-40$ of this edition.

\section{c. First British edition:}

The Marijuana/ Papers/ Edited by David Solomon/ Introduction by/ Alfred R. Lindesmith Ph.D./ Panther Modern Society

$7 \times 43 / 8$ in. 480 pp.

P.[1] reads in part: The Marijuana Papers was first published in/ the U.S.A. in 1966. This new, revised edition/ is its first publication in Britain. P. [4] reads in part: A Panther Book/ First published in Great Britain by/ Panther Books 1969. Pp. [476-80] contain publisher's ads. 
Wrappers are printed in white and black and have photograph of a marijuana cigarette under a microscope on front cover, blurb on back cover.

The text of this edition (a Panther Modern Society book) is substantially revised, but Leary's article on pp. 154-75 is unchanged.

B12

THE BOOK OF GRASS

a. First edition:

The Book of Grass/ AN ANTHOLOGY ON INDIAN HEMP/ edited by/ GEORGE ANDREWS/ and/ Simon Vinkenoog/ (publisher's device)/ PETER OWEN • LONDON

$87 / 16 \times 57 / 16$ in. xiv, $242 \mathrm{pp}$.

[i] title; [ii] PETER OWEN LIMITED) 12 Kendrick Mews Kendrick Place London SW7/ C Peter Owen 1967/ Printed in Great Britain by/ Bristol Typesetting Co Ltd/ Barton Manor Bristol 2; iii-v Contents; vi Illustrations; vii-x Introduction by George Andrews; xi-xiii Acknowledgments and Sources; [xiv] blank; 1-242 text. There are three inserted plates on glossy paper: facing the title, between pp. 82 and 83 , and between pp. 114 and 115 . There are six figures in the text.

Gray boards, spine stamped in gilt: The/ Book/ of/ Grass/ (ornament )/ ANDREWS/ (publisher's device)/ PETER/ OWEN. Dust jacket white, printed in black and green. Front panel prints title, list of contributors, editors' names and graphic design. Back panel prints publisher's device. Spine prints title, editors' names, publisher's name and device.

Published June $1967 @$ 37s.6d. 2,000 copies printed.

Contains "The Politics of Consciousness Expansion" by Leary and Alpert, pp. 208-10. Reprinted from The Harvard Review, 1963 (C22). See AA42 for offprint form and annotation. Article is preceded by brief note about Leary's thirty-year sentencing for marijuana possession; pp. 221-23 contain documentation of this.

b. First U.S. edition:

The Book of Grass/ AN ANTHOLOGY ON INDIAN HEMP/ edited by/ GEORGE ANDREWS/ and/ Simon Vinkenoog/ GROVE PRESS, INC./ NEW YORK

$81 / 4 \times 57 / 16$ in. xiv, $242 \mathrm{pp}$. 
Photo-offset reprint of B12a, to which it collates identically, except the three inserted plates are lacking, p. [vi] is blank, and p. [ii] reads as follows: Copyright (C) 1967 by Peter Owen/ All Rights Reserved/ Library of Congress Catalog Card Number: 67-27166/ First Printing/ Manufactured in the United States of America.

Blue cloth, spine stamped in gilt: The/ Book/ of/ Grass/ Andrews/ \&/ Vinkenoog/ Grove/ Press. Endpapers white. Dust jacket white and black printed in black, blue, green and white. Front panel shows representation of a marijuana plant. Back panel prints "Partial Table of Contents." GP-423 printed at back of spine panel.

Published $1967 @ \$ 5.00$. Number of copies unknown (publisher's records lost).

\section{c. First paperback edition:}

The Book of Grass/ AN ANTHOLOGY OF INDIAN HEMP/ edited by/ GEORGE ANDREWS/ and/ Simon Vinkenoog/ GROVE PRESS, INC./ NEW YORK

$7 \times 43 / 16$ in. xiv, 242 pp.

Reduced photo-offset printing of B12b, with variations in the preliminary leaves. Copyright page [iv] reads in part: First Evergreen Black Cat Edition 1968.

Stiff, glossy, white and black wrappers printed in black, green, blue and white. Front cover and spine similar to dust jacket of B12b. Back cover contains blurb.

Published $1968 @ \$ 1.25$. Number of copies unknown. Evergreen Black Cat edition B-166. There were four paperback printings, the fourth (so designated in copyright page) is most noticeable for the front cover, which has, in place of the image of a marijuana plant, a photograph of a man holding a marijuana cigarette to a woman's lips. Price remains@ @ \$1.25; edition number changes to B-166-Z.

\section{B13 HISTORY OF THE PSYCHEDELIC MOVEMENT 1967}

\section{First edition:}

(in center of page surrounded by reproduction of 19th-century engraving of an exotic island with flora and fauna:) HISTORY OF THE/ PSYCHEDELIC MOVEMENT/ CARTOON \& COLORING BOOK

$107 / 8 \times 8$ in. 64 pp. 


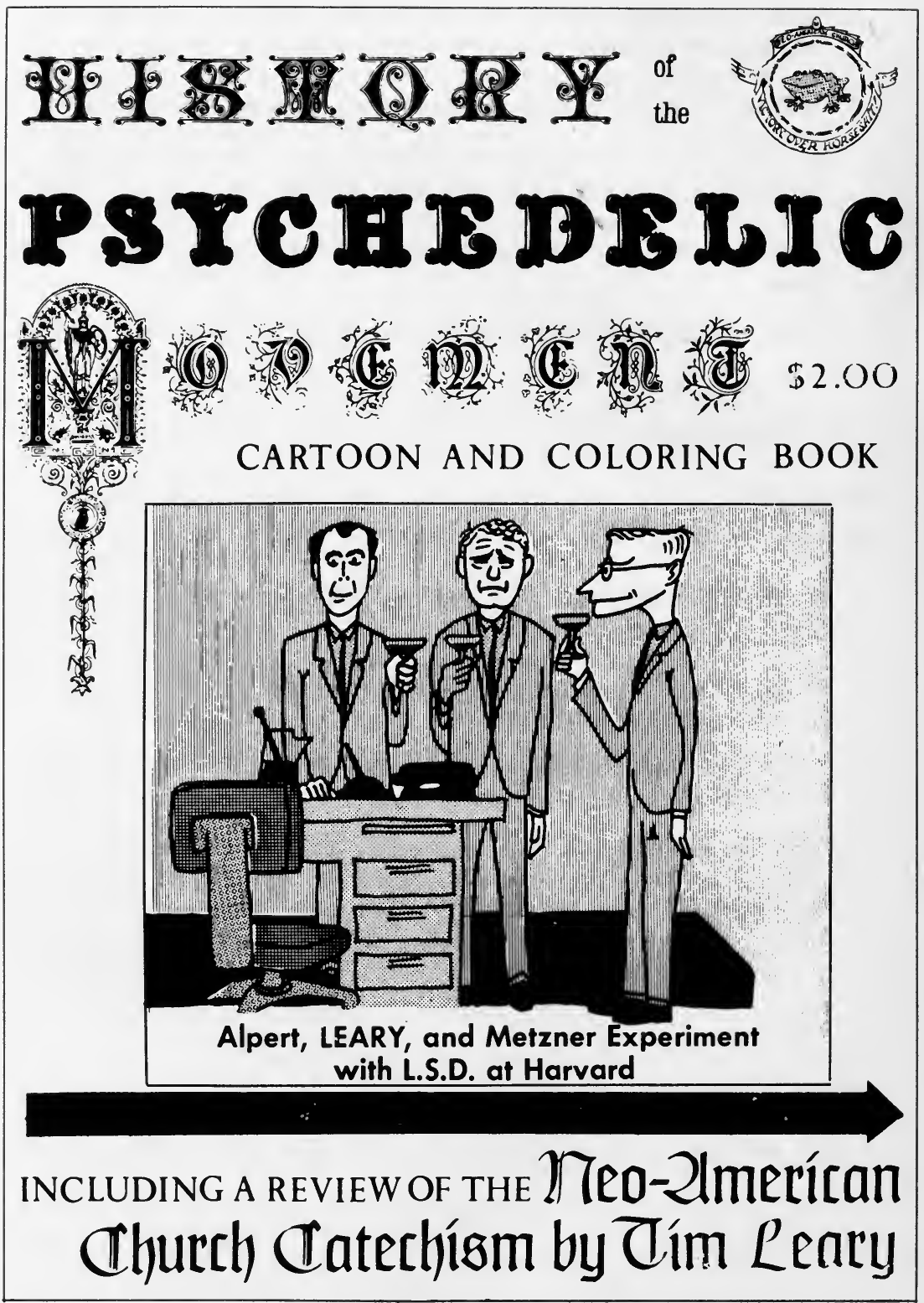

B13: Satire on the psychedelic movement, privately published at Millbrook, N.Y. (1967). 
[1] title; [2] (seven-line dedication)/Published by The Neo-American Church, Inc./ Box 694, Millbrook, N.Y./ Copyright 1967 by The Neo-American Church, Inc./ (incorporated under the laws of the State of New York)/ All rights reserved/ May not be re-printed, in whole or in part, without permission/ from the Chief Boo Hoo of The Neo-American Church, Art Kleps./ Printed by Douglas Fairbanks, Sr.;[3]-[58] full-page captioned cartoon drawings for coloring; [59]-[60] text; [61]-[64] illustrated ads and membership applications.

Yellow and orange stiff paper wrappers printed in red, green and black. Front cover (printed in variety of types): HISTORY of the (device of the Neo-American Church)/ PSYCHEDELIC/MOVEMENT \$2.00/ CARTOON AND COLORING BOOK/ (cartoon captioned "Alpert, LEARY, and Metzner Experiment/ with L.S.D. at Harvard)/ FOR RESULTS SEE BACK COVER/ INCLUDING A REVIEW OF THE Neo-American/ Church Catechism by Tim Leary. Back cover: (cartoon of Alpert, Leary and Metzner psychedelicized, captioned) With the Usual Consequences. Spine blank.

Published $1967 @$ @2.00. Publishing records unavailable.

Contains "The Neo-American Church Catechism and Handbook, a Review," on pp. [59-60]. This review appeared at approximately the same time in East Village Other (C49). It was reprinted in the second edition of The Boo Hoo Bible (B25).

\section{a. First edition:}

The Art/ of Ecstasy/ an investigation/ of the/ psychedelic revolution/ by William Marshall/ and/ Gilbert W. Taylor/ Burns \& MacEachern/ Limited [Toronto, Canada]

\section{$8 \times 5 \frac{1}{4}$ in. $207 \mathrm{pp}$.}

[1] right half of illustrated endpaper; [2-3] endpaper illustration repeated in reduced format; [4] same illustration further reduced; [5] title; [6] same illustration further reduced; [7] () 1967,/ by/ William Marshall/ and/ Gilbert W. Taylor/ published by/ Burns \& MacEachern/ Limited/(thirteen lines regarding rights); [8] endpaper illustration further reduced; [9] dedication; [10] endpaper illustration further reduced; [11] Acknowledgments; [12] endpaper illustration further reduced; [13] reprint permissions; [14] endpaper illustration further reduced; [15] Contents; [16] design and illustrations credits/ [17] Foreword by Sidney Katz; [18] blank; [19] fly-title; [20]-207 text; [208] blank. 
Stiff, yellow wrappers, with overall circular bull's eye design printed in orange, with eye in center and figure of woman inside the eye. Front cover text: The Art of Ecstasy/ AN INVESTIGATION OF THE PSYCHEDELIC REVOLUTION/ by William Marshall \& Gilbert W. Taylor/ Designed and Illustrated by Martin Walsh/ (lower right) \$4.50. Back cover: publisher's blurb. Spine: (printed vertically:) The Art of Ecstasy Marshall Taylor Walsh (horizontally:) publisher's device.

Published in $1967 @ \$ 4.50$. Publishing records unavailable.

Contains "The Speech That Never Was," pp. 82-101, followed by photograph of Leary on pp. 102-3. Also, photograph and biographical note on Leary, pp. 21-23. The speech is described in the table of contents as "the notorious speech which Timothy Leary was banned from delivering in person or on tape to University of Toronto students." The speech was to have been delivered in 1967 at the symposium Perception '67.

b. First U.S. edition:

The Art/ of Ecstasy/ an investigation/ of the/ psychedelic revolution/ by/ William Marshall/ and/ Gilbert W. Taylor/ 1968 EDITION/Wilshire Book Company/ 8721 Sunset Blvd./ Hollywood, California, 90069 (publisher's device to left and right).

$81 / 4 \times 51 / 4$ in. $216 \mathrm{pp}$.

Reissue of the sheets of B14a by a different publisher, with a different cover and covertitle, and the following differences in collation: [1] publisher's blurb in two columns; [5] title (above); [209-13] publisher's ads; [214-16] blank pages marked "Notes."

Stiff wrappers printed in pink, yellow and gray, with photographic image of a woman in psychedelic distortion across both covers. Front cover text: (at upper left): \$2/ PSYCHEDELIC/ ECSTASY/ William Marshall/ Gilbert W. Taylor. Spine: (printed vertically:) PSYCHEDELIC ECSTASY William Marshall/ Gilbert W. Taylor Wilshire Book Co.

Published $1968 @ \$ 2.00$. Undisclosed number of copies printed.

"The title of this unusual book, THE ART OF ECSTASY, comes from the writings of Timothy Leary, the high priest of the psychedelic revolution" (publisher's blurb, p. [1]. 


\section{a. First edition:}

PLAYBOY/ INTERVIEWS/ selected by the editors of/ PLAYBOY/ (publisher's device)/ PLAYBOY PRESS

$81 \frac{1}{4} \times 5 \frac{1}{2}$ in. viii, $408 \mathrm{pp}$.

[i] half-title; [ii] blank; [iii] title; [iv] Copyright $(\mathcal{O} 1967$ by HMH Publishing Co., Inc. All rights reserved. From/ PLAYBOY (B) magazine: Copyright (C) 1963, 1964, 1965, 1966 by HMH Publishing/ Co., Inc./ (two lines of printing information)/ Catalog Card Number: 66-11050. First edition./ (rule)/ (seven lines of photo credits); [v] Contents; [vi] blank; vii-viii Preface by the editors of Playboy; [1] fly-title; [2]-406 text; [407-8] blank.

Gray cloth. Playboy device (rabbit) blind-stamped on lower right of front cover. Spine lettered in silver: (printed vertically:) PLAYBOY INTERVIEWS/ (horizontally) PLAYBOY/ PRESS. Endpapers white. Dust jacket printed in red on black, with photographs and captions from interviews of Leary, Ringo Starr, Martin Luther King, Jr. (top row, front panel), and nine others on both panels.

Contains: "Playboy Interviews Timothy Leary," pp. 124-61. On p. 124 is a photo of Leary by Jerry Yulsman. This interview was originally published in Playboy, Sept. 1966 (D1). See AA47 for offprint form and annotation.

Published $1967 @ \$ 5.95$. Undisclosed number of copies printed.

\section{b. Second edition:}

The/ PLAYBOY/ INTERVIEW/ (within square ruled frame:) Edited by G. Barry Golson/ WIDEVIEW/ (device)/ BOOKS

$9 \frac{1}{2} \times 6 \frac{1}{8}$ in. xvi, $722 \mathrm{pp}$.

Copyright page [iv] reads in part: (C) 1981 by Playboy/ FIRST EDITION.

Glossy, white wrappers printed in red, brown, blue and black. Front cover prints title, editor and (under "Classic Conversations") a partial list of contributors; at bottom, three portraits in red, blue and green. Back cover: quotations from interviews. Spine: author, title and imprint.

Published May 1, $1981 @ \$ 9.95$. 11,353 copies printed. There was no hardbound issue. 
Contains "Timothy Leary, September 1966. Interview: Bernard Grauzer," pp. 179-200. In this expanded edition of B15a, the interviewer is identified and the first two pages contain an introductory note by the editor of the volume, G. Barry Golson, recalling the circumstances of the interview: how the first draft was not "tough enough" and the editors were afraid that Leary would mislead their readers about the sexual potential of LSD.

a. First edition:

ALTERnATIVES To VIOLENCE/ $A$ Stimulus to Dialogue/ TIME-LIFE BOOKS, NEW YORK

$9 \times 6$ in. 160 pp.

[1] half-title; [2] blank; [3] title; [4] (publisher's device)/ (C) 1968 TIME INC. ALL RIGHTS RESERVED./ Published simultaneously in Canada./ Library of Congress catalogue card number 68-57111.; [5] Preface; [6] Adam the Inventor by Pete Seeger (music, lyrics and copyright); [7] untitled poem by editor; [8-9] Contents; [10] fly-title; 11-159 text; [160] (four lines of production credits). Fly-titles on pp. [10], [44], [76] and [114] printed in white on brown paper.

Yellow cloth printed in black. Front cover: ALTERNATIVES TO VIOLENCE. Spine: (printed vertically:) ALTERNATIVES TO VIOLENCE/ (horizontally:) publisher's device. Endpapers black. Dust jacket two shades of yellow, printed in black. Front panel: depiction of shattered half of eyeglasses overlaid on title, listing of the twenty-one contributing authors, publisher's imprint. Back panel: quotations from book/Library/ SILVER BURDETT/ Edition. Spine text identical to cloth cover.

Published Aug.1968@ @3.95.10,000 copies printed.

Contains "Violent Governments, Nonviolent Hippies" on pp. 88-103. A slightly different and (possibly) earlier version was published under the title "Government Violations and the Non-Violent Hippies" in Harbinger (C57a); this version weas reprinted in Countdown (C66) under the title "Violence Is Killing By Machines At a Distance."

This essay deals with the violence of governments and the necessity of disassociating from them, and the values of psychedelic drugs and the hippie lifestyle in this regard. Other contributors to this volume were Arthur Koestler, Erich Fromm, Alan Watts, Glenn Seaborg, Arnold Toynbee and Robert McNamara. 
$9 \times 57 / 8$ in.

Collation identical to hardbound issue.

Stiff wrappers identical to dust jacket of hardbound issue, except for the following: color is lighter shade of yellow; price (\$1.00) appears in upper left corner of front cover; "Library/ SILVER BURDETT/ Edition" is deleted from foot of back cover.

Published Aug.1968@ @1.00. 50,000 copies printed. Second printing: date unknown, 30,000 copies, same price.

\section{B17 NOTES FROM THE NEW UNDERGROUND}

\section{a. First edition:}

Notes from the/ New Underground/ AN ANTHOLOGY/ EDITED BY JESSE KORNBLUTH/ NEW YORK / [printed slash] THE VIKING PRESS

$9 \frac{1}{4} \times 65 / 8$ in. $x v i, 304$ pp.

[i] half-title; [ii] calligraphic design; [iii] title; [iv] two-line dedication/ Copyright (C) 1968 by Jesse Kornbluth/ All rights reserved/ First published in 1968 by The Viking Press, Inc./ 625 Madison Avenue, New York, N.Y. 10022/ Published simultaneously in Canada by/ The Macmillan Company of Canada Limited/ Library of Congress catalog card number: 68-22874/ Printed in U.S.A./ The following two pages constitute an extension of this copyright page.; [v-vi] list of copyright owners; vii-ix Contents; [x] newspaper story dated July 10, 1968; xi-xv Introduction; [xvi] blank; [1] fly-title; [2] blank; [3]-302 text; [303-4] blank.

Black linen cloth. Front cover stamped in purple with abstract calligraphic design. Spine stamped vertically in silver: Notes from/ the New/ Underground/ (abstract calligraphic design stamped in purple)/ Edited by/ Jesse Kornbluth/ Viking. Top edge stained gray. Endpapers white. Dust jacket printed in black and gray, with abstract group of figures on front panel, overprinted with title at left and editor's name at right. Back panel: quotation from book, publisher's imprint, SBN 670-51713-5. Spine prints editor's name, title and publisher.

Published 1968 (after July) @ \$7.50. Undisclosed number of copies printed.

Contains "Changes," a four-way dialogue between Allen Ginsberg, Timothy Leary, Gary Snyder and Alan Watts, pp. 121-83, its first appearance in book form. Reprinted from The City of San Francisco Oracle (C46). 


\section{b. First paperback edition:}

Notes from the/ New Underground/ An Anthology/ Edited by JESSE KORNBLUTH/AN ACE BOOK/ Ace Publishing Corporation/ 1120 Avenue of the Americas/ New York, N.Y. 10036

$7 \times 4 \frac{1}{8}$ in. 320 pp. P. [4] states: An Ace Book, by arrangement with The Viking Press, Inc. Glossy white wrappers printed in black, blue and red, with illustration on front cover, blurbs on back. Edges stained yellow. Published in $1968 @ \$ 1.25$. Number of copies undisclosed. Ace Books \#58875.

"Changes" occupies pp. 139-204 of this edition.

B18 THE BEATLES BOOK 1968

First edition:

THE/ BEATLES/ BOOK/ (rule)/ Edited by/ Edward E. Davis/ A COWLES BOOK

$87 / 8 \times 57 / 8$ in. viii, $216 \mathrm{pp}$.

[i] half-title; [ii] blank; [iii] title; iv (fifteen lines of copyright data)/ Copyright (C) 1968 by Cowles Educational Corporation/ LOOK Building, 488 Madison Avenue, New York, N.Y. 10022/ First Edition/ (three lines pertaining to permission to reproduce)/ Published simultaneously in the United States and Canada./ Copyright under the International Copyright Convention./ Printed in the United States of America/ Library of Congress Catalog Number 68-58357; v Preface; vi Acknowledgments; vii Contents; [viii] blank; [1]-213 text; [214-216] blank.

Blue cloth, spine stamped in gilt: (printed vertically:) THE BEATLES BOOK (publisher's device) COWLES. Endpapers white. Dust jacket white and black, printed in black, white and pink. Front panel: four multicolored psychedelic photos of each Beatle by Richard Avedon, with title above, editor's name below. Back panel: blurb, photograph of Beatles, quotations from book (including one from Leary's article), publisher's device, no. 10141. Text of spine identical to that of cloth spine.

Published $1968 @$ \$5.95. Publishing records unavailable.

Contains "Thank God for the Beatles," pp. 44-55, (C) 1968 by the League for Spiritual Discovery, Inc. First appearance in print of this essay about the Beatles as "evolutionary agents sent by God, endowed with mysterious power to create a new human species," with reflections on the group's new interest in Eastern religion. 


\section{First edition:}

THE/ TALES/ OF/ HOFFMAN/ (rule)/ Edited from the official transcript by/ MARK L. LEVINE/ GEORGE C. McNAMEE/ DANIEL GREENBERG/ (rule)/ Introduction by Dwight Macdonald/ (rule)/ Including thirty-two pages of on-the-scene sketches/ (device circularly surrounded by text) BANTAM BOOKS • NEW YORK • TORONTO • LONDON/ A NATIONAL GENERAL COMPANY

$7 \times 4 \frac{1}{8}$ in. xxviii, 290 pp.

[i-iv] quotations from book; [v] title; [vi] THE TALES OF HOFFMAN/ A Bantam Book (printed /) published March 1970/ Illustrations and cover artwork copyright (C) 1969, 1970/ by National Broadcasting Company/ All rights reserved./ Copyright ( 1970 by Bantam Books, Inc./ The complete trial transcript in the case of/ U.S. vs. Dellinger, et al. is in the public domain./. (three lines pertaining to reproduction rights)/ Published simultaneously in the United States and Canada/ (rule)/ (five lines regarding Bantam trademark)/(rule)/ PRINTED IN THE UNITED STATES OF AMERICA; [vi] Acknowledgments; [vii] blank; [ix] Contents; [x] blank; xi-xxiv Introduction by Dwight McDonald; xxv-xxvi Editors' Foreword; [xxvii-xxviii] fly-title; 1-286 text; [287-289] Appendix; [290] About the Editors. There are thirty-two pages of sketches of the trial between pp. 132 and 133.

White glossy wrappers, printed and illustrated in black, red, blue, gray and brown. Cover art depicts scenes from the trial of the Chicago 8. Front cover along spine: TZ5738 * $\$ 1.50 *$ A BANTAM EXTRA/ from the trial/ of the Chicago 8 (number slashed out, replaced by 7)/ The Tales/ of Hoffman/ A documentary of courtroom confrontation from the/ most incredible trial in American history/ (four lines giving names of editors and introduction writer)/ Including thirty-two pages of on-the-scene sketches. Back cover: caption for illustration. Spine: (device)/ NON-/ FICTION/ (rule)/ (printed vertically:) The Tales of Hoffman/ (editor's names)/ (horizontally:) 553/ 05738/ 150.

Published Mar.1970@ @1.50. Unknown number of copies printed.

Contains "December 19, 1969. Direct examination of Defense Witness, Dr. Timothy Leary, former Harvard professor, by Mr. [William] Kunstler," pp. 133-35, the first publication of any part of Leary's testimony, as excerpted by the editors from the official trial transcript.

A portion of this excerpt was reprinted in Verdict! (BB5). 


\section{a. First edition:}

GETTING/ BUSTED/ PERSONAL EXPERIENCES OF ARREST TRIAL and PRISON/ EDITED BY ROSS FIRESTONE/ A DOUGLAS BOOK/ Distributed by the World Publishing Company

$81 / 4 \times 51 / 2$ in. xii, $348 \mathrm{pp}$.

[i] half-title; [ii] blank; [iii] title; iv Copyright 1970 by Douglas Book Corporation./ All Rights Reserved/ Library of Congress Catalog Card Number: 70-142526/ (two lines pertaining to reproduction rights)/ First Printing/ Manufactured in the United States of America/ DESIGN: BOB CATO AND IRA FRIEDLANDER/ ACKNOWLEDGEMENTS/ (rule)/ (twenty-eight lines of copyright data); v-vii (continuation of copyright data); viii-ix Contents; Editor's Preface; xi-xii Introduction by Martin Garbus; [1] fly-title to section one; [2] blank; 3-347 text; [348] blank.

Red cloth, stamped in silver on spine: GETTING BUSTED. EDITED/ BY ROSS FIRESTONE. DOUGLAS. Dark gray endpapers. Red, white and blue striped silk ribbon marker. Dust jacket silver, printed in red and blue. Front (identical to cover of B20b) and back panels display (in reverse color arrangement) title, editor, and list of nineteen contributors. Spine displays title, editor, publisher. Quotation from Leary's contribution appears on front flap.

Published November 1970 @ \$5.95. 2,500 copies printed.

Contains "Episode and Postscript" on pp. 168-90, which originally appeared in Playboy (C62). This is an account of the author's arrest at Laredo, Texas in 1965, his sentence of thirty years for a half-ounce of marijuana, and the eventual ruling by the U.S. Supreme Court overturning his conviction. Contributors to this book include: Malcolm X, Bertolt Brecht, Billie Holiday, Eldridge Cleaver, Joan Baez, Norman Mailer, Ken Kesey. "Millbrook Raid: An Eyewitness Report," author anonymous, pp. 6-8, describes the police raid of Leary's commune in Apr. 1966.

\section{b. First (simultaneous) paperback edition:}

$8 \frac{1}{4} \times 53 / 8$ in. Collates identically with B20a, except there are no endpapers.

Stiff, silver wrappers printed in red and blue. Front cover: A DOUGLAS BOOK/ GETTING BUSTED/ PERSONAL EXPERIENCES OF ARREST TRIAL AND PRISON/ (seven-line list of contributors)/ EDITED BY ROSS FIRESTONE. Back cover: (along top edge:) \$2.45 A4070P/ title, imprint, blurb, six quotations from book, including one by Leary, book design credits. Spine: GETTING BUSTED EDITED BY ROSS FIRESTONE DOUGLAS.

Published Nov.1970@\$2.45. 10,000 copies printed at \$2.45.

Note: The LC number is the same for this book as it is for JailNotes (A12), due to a publisher's error. 
c. First mass-market paperback edition:

GETTING/ BUSTED/ PERSONAL EXPERIENCES/ OF ARREST, TRIAL AND PRISON/ Edited by ROSS FIRESTONE/ ARENA BOOKS - NEW YORK

$7 \times 4 \frac{1}{8}$ in. $x x, 496$ pp.

Copyright page [iv] reads in part: Arena edition published September 1973/ Arena Books are published by Pyramid Communications, Inc./ 919 Third Avenue, New York, New York 10022.

Black and white paper wrappers, printed in red, orange, blue, white and black. Front cover lists contributors; back cover contains excerpts from book.

Published September $1973 @ \$ 1.75$. Approximately 25,000 copies printed.

Leary's contribution occupies pp. 246-78 of this edition. Arena Books no. M3013.

\section{d. First British edition:}

Getting Busted/ Personal Experiences of Arrest, Trial/ and Prison/ Edited by Ross Firestone/ Penguin Books

$71 / 8 \times 43 / 8$ in. $432 \mathrm{pp}$.

Copyright page [iv] reads in part: Published in Penguin Books 1972.

Green and orange paper wrappers printed in red and black with shackled hand displaying peace sign in white on front and back.

Published 1972 @ 50p. Approximately 25,000 copies printed.

Leary's contribution occupies pp. $213-40$ of this edition.

\section{a. First edition:}

POT ART FOR POT HEADs/ MARIJUANÁ READING MATTER/ An anthology of reprints/ from the popular press/ (silhouette of a cannabis plant)/ (to left:) EDITED:/ CULLED:/ COLLAGED:/ by stone mountain (to right:) PUBLISHED BY/ Apocrypha Press/ Box 12519/ Tucson, Arizona 85711

$11 \times 8 \frac{1}{2}$ in. 160 unnumbered pp. 
[1] POT ART/ First Edition/ CC 1970 Stone Mountain; [2] title; [3] dedication (to George Washington); [4-160] illustrated text.

Red-orange wrappers printed in bright green and white. Front cover: marijuana reading matter/ POT/ ART/ (stylized drawing of cannabis plant)/ stone mountain. Back cover: (upper right:) \$2.98/ AP-1/ POT ART/ marijuana reading matter/ (quotations by Allen Ginsberg, Michael Aldrich, etc.)/ APOCRYPHA. Spine: (printed vertically:) POT ART/ marijuana reading matter/ APOCRYPHA PRESS.

Published after Sept. 22, 1970 (date of one back cover blurb) @ \$2.98. Publishing records unavailable.

Contains "Deal for Real," pp. 95-96. This is the first publication in book form of this article, which originally appeared in East Village Other (C61). Also included are five full-page photocollages of Leary, including: photoreproduction of Leary at John and Yoko Lennon's Bed-In; Timothy Leary For Governor poster; press cutting on his thirty-year sentence for marijuana possession; with daughter Susan; and two from Millbrook period. The author's name ("Stone Mountain") is a pseudonym for Walter Bowart, who was then publisher of East Village Other, a New York underground newspaper. "Deal for Real" was later reprinted in Underground Press Anthology (BB9).

\section{b. Second edition:}

POT ART FOR POT HEADS/ MARIJUANA READING MATTER/ An Anthology of reprints/ from the popular press/ (silhouette of a cannabis plant)/ (to left) EDITED:/ CULLED:/ COLLAGED:/ by stone mountain (to right) PUBLISHED BY/ Apocrypha Books/ a division of OMEN PRESS/ Box 12519/ Tucson, Arizona 87511

$11 \times 83 / 8$ in. 200 unnumbered pp.

[1] POT ART/ (C) 1972 Apocrypha Books; [2] title; [3] dedication; [4-200] illustrated text.

Minor cover changes include a yellowish tone to the green ink, variant lettering and rearranged matter on both covers, variant lettering on spine. Back cover states: Enlarged Second Edition.

Published in $1972 @ \$ 3.95$. Publishing records unavailable.

"Deal for Real" occupies pp. [109-10] in this edition. 
First edition:

NEW APPROACHES/ TO PERSONALITY CLASSIFICATION/ EDITED BY ALVIN R. MAHRER/ (rule)/ COLUMBIA UNIVERSITY PRESS/ NEW YORK AND LONDON/ 1970/ (rule)

$91 \frac{1}{8} \times 6$ in. [xii] $428 \mathrm{pp}$.

[i-ii] blank; [iii] half-title; [iv] blank; [v] title page; [vi] (two lines concerning Mahrer's credentials)/ Copyright (C) 1970 Columbia University Press/ Standard Book Number: 231-03296-X/ Library of Congress Catalog Card Number: 73-96313/ Printed in the United States of America; [vii] Contributors; [viii] blank; [ix-xi] Contents; [xii] blank; 1-414 text; 415-425 Index; [426-28] blank.

Mustard cloth, spine stamped in red and gilt: MAHRER/ (on blue band:) NEW/ APPROACHES/ TO/ PERSONALITY/ CLASSIFICATION/ COLUMBIA. Endpapers white. Dust jacket white and pale blue, printed in black and white. Front panel has blue and yellow abstract photographic closeup, with title and editor's name. Back cover prints ads for other books. Spine displays title, editor, and publisher.

Published June 1, 1970 @ \$12.50. Undisclosed number of copies printed.

Contains "The Diagnosis of Behavior and the Diagnosis of Experience" on pp. 211-36, the first publication of this work. Three tables and one figure are included in the text.

Leary describes his "existential-transactional" diagnostic system, drawing on his research from the late ' 40 s to the mid '60s. Table 1: The Philosophy of Internal and External. Table 2: Sheet for Recording Ten-Minute Samples of Space-Tine Locations and the Contents of Consciousness. Table 3: Illustration of a Simplified Schema for Classifying Space-Time Aspects of Interpersonal Behavior. Figure 1: Percentage of Verbal Movements by Patient and Therapist Referring to Patient as Subject during Twelve Hours of Psychoanalytically Oriented Psychotherapy.

a. First edition:

WEATHERMAN/ (rule)/ Edited by Harold Jacobs

$8 \times 5^{1 / 2}$ in. $[x x], 524$ pp.

[i] half-title; [ii] blank; [iii] title; [iv] Copyright @ 1970 by Ramparts Press, Inc./ (three lines referring to reproduction rights)/ Library of Congress Catalog Card 
Number: 75-132205/ SBN Number: 671-20725-3; [v] dedication (to the Vietnamese people); [vi] blank; [vii-ix] Contents; [x] blank; [xi-xiii] Preface; [xiv] blank; [xv-xviii] Chronology of Events; [xix-xx] blank; 1-519 text; [520-24] blank.

Black cloth, spine stamped in white (printed vertically): WEATHERMAN HAROLD/ JACOBS/ (horizontally:) publisher's device. Endpapers white. Dust jacket black and white, printed in black, white and red. Front panel: title and editor's name across photo of a Weatherman demonstration. Back panel: quotation from Jacobs and blurb ("the first complete picture of Weatherman in the words of those who theorized, those who acted and those who watched it all"). Spine panel lettering identical to cloth spine.

Published Jan.1971@ @10.25.1,000 copies printed.

Contains "Letter From Timothy Leary" on pp.[517]-519, the first publication of Leary's prison escape letter in book form. The letter was originally published in SF Good Times, 18 September 1970 (C70); it was later reprinted under the title "Manifesto" in Counterculture and Revolution (BB8) and in part in The Weather Underground (BB13). Leary's "Letter" is preceded by "Communique \#4 From the Weatherman Underground," p. [576], signed Bernadine Dohrn, pertaining to Leary's Weatherman-assisted escape (J204).

\section{b. First (simultaneous) paperback edition:}

$8 \times 5 \% 16$ in.

Collation identical to B23a.

Stiff, semi-glossy wrappers identical to dust jacket of B23a, except for the following added beneath the blurb on back panel: Cover Photo: (C) Pterodactyl/ Printed in USA/ SBN 20725.

Published Nov.1970@ \$3.45.35,000 copies printed.

First edition:

WHISPER/ a timescript

$81 / 4 \times 5$ in. 128 pp.

[1] half-title; [2] (C) Copyright 1971 by Whisper Promotions/ First published in Great Britain by/ Whisper Promotions,/ Holland Park Studio, 247 Walmer Road, 
London W11/ designed by Some Studio/ Printed in Great Britain by/ Whitefriars Press Ltd., London and Tonbridge; [3] title page; 4 (ten-line author note describing conditions of writing and publishing this book); [5-6] (manuscript facsimile); [7] WHISPER/ IS PURE/ PERFECT/ SCRIPT/ Timothy and Rosemary Leary, Algiers 1971; [8] contents; [9] facsimile of page of a notebook given to prisoners; $10-128$ text.

Black leather boards gilt-stamped. Front cover: (in calligraphic script:) WHISPER. Back cover: large dot in center. Spine: (printed vertically:) Whisper. Photographic endpapers.

Published Sept.15,1971@£1.92. Information from prospectus; publishing records unavailable.

Written by Brian Barritt.

Contains "The Wanderers," pp. 124-28, a postscript by Tim and Rosemary Leary, dated Algers, Algerie, March 1971. The Learys also supplied the epigraph on p. [7]. Author's note on p. 4 explains that "these writings were smuggled out of Her Majesty's prison between November 1966 and September 1969," where the author was confined for "possession of four pounds of hashish." The author, Brian Barritt, formed Whisper Promotions with David Ball. "In December 1970 a manuscript was delivered to Timothy and Rosemary Leary who endorsed it with a postscript-The Wanderers." Barritt spent time with Leary in Algeria during 1971. "The Wanderers" was reprinted in different form within a longer work, "Scripts [I-XV]" by Leary and Barritt, published in Renaissance 1972 (C79).

Second edition:

THE BOO HOO BIBLE/ (twenty-two lines describing contents, beginning:) HOW TO GUIDE A SESSION FOR MAXIMUM MIND LOSS (ending:) CATALOGUE CARTOONS NEWS ITEMS (with row of arrows following line 9 and row of asterisks following line 21 ; the whole text enclosed within an elaborate engraved border with a toad in central position at top)

$9 \times 6$ in. [ii] 218 pp.

[i] blank except for toad at bottom right; [ii] Published by Toad Books/ Box 14, San Cristobal, N.M. 87564/ (C) Copyright 1971 by Arthur J. Kleps/ All rights reserved/ (three lines regarding permission to reprint)/ SBN 0-9600388-1-7/ (two-line quotation from Thoreau)/ logo of Blue Feather Press; [1] title; [2]-212 text; [213-18] List of members and membership applications for joining the Neo-American Church. 
Stiff wrappers printed in black, white, yellow, red, pink and blue. Front cover (across cartoon drawing of the planet Saturn being blown up by rocket ships:) THE BOO HOO/ BIBLE/ \$5/ THE NEO-AMERICAN CHURCH CATECHISM/ WITH A REVIEW BY TIMOTHY LEARY/ ART KLEPS. Back cover: logo of Neo-American Church followed by eight-line note about it. Spine (printed vertically): BOO HOO BIBLE KLEPS. Endpapers have black and white cartoon in nine panels, "The Destruction of Saturn."

Published1971@\$5.00. Publishing records unavailable.

Contains "The Great Millbrook Snot Bust," p.60; "The Neo-American Church Catechism and Handbook, a Review," pp. 205-8. The former article first appeared in East Village Other (C44); the latter in History of the Psychedelic Movement Cartoon and Coloring Book (B13), also authored by Art Kleps. Neither article appeared in the first edition of this book. A number of other pages deal with Leary at Millbrook.

(Note: this entry is for identification purposes only; the book was discovered too late for a standard entry to be made.)

\section{First edition:}

Human Alternatives: Visions for Us Now. Edited with an Introduction by Richard Kostelanetz. New York: William Morrow and Company, Inc., 1971.

$81 \frac{1}{4} \times 5 \frac{1}{2}$ in. xxxiv, 300 pp. Black cloth, spine lettered in gilt. Dust jacket black, with red and yellow bands on front panel.

Contains "Prediction," pp. 70-80, reprinted from Southern California Oracle (D8)

a. First edition:

(eleven rules)/ OUR TIME/ (five stars)/ An Anthology of Interviews from the/ EAST VILLAGE OTHER/ Compiled and Edited by ALLEN KATZMAN/ THE DIAL PRESS (publisher's device) NEW YORK, 1972 
$8 \times 53 / 8$ in. [viii] 408 pp.

[i] half-title; [ii] Other Books by Allen Katzman/ (six lines of titles); [iii] title; [iv] Copyright (C) 1972 by Allen Katzman/ (four lines pertaining to rights of reproduction )/ Library of Congress Catalog Card Number: 75-163596/ Printed in the United States of America/ First Printing, 1972/ Design by Lynn Braswell; [v-vi] The Coming of a Counterculture (preface); [vii-viii] Contents; [1]-407 text; [408] About the Editor. Pp. [216-36] comprise illustrations, including one of Leary on p. [222].

Orange cloth. Front cover stamped with three horizontal double rows of purple stars. Spine printed in purple and black: Katzman/ (printed vertically:) OUR TIME Interviews from/ THE EAST VILLAGE OTHER/ (printed horizontally:) (device)/ (rule)/ THE/ DIAL/ PRESS. Back cover blank. Black endpapers. Dustjacket: front and back panels and spine identical to cover of A26b except: price printed on inside flap instead of front panel; spine lettering slightly reduced without number at top; back panel deletes "Printed in U.S.A." Inside front flap displays price and long quotation from Library Journal; inside back flap has picture and biographical note on the editor, and jacket design credit (Mike McIver).

Published Feb. 28, $1972 @ \$ 8.95 .2,000$ copies printed.

\section{b. First (simultaneous) paperback edition:}

Size and collation identical to B26a.

Stiff, white, black and pink wrappers, printed in orange, red, pink, white and black. Front cover: \$2.65/ OUR TIME/ Interviews from/ THE EAST VILLAGE OTHER/ compiled and edited by/ Allen Katzman/ images of four issues of East Village Other)/ (at left:) partial list of authors/ Back cover: continued list of authors printed over photograph of semi-clothed youths/ Printed in U.S.A. Spine: 6749/ Katzman/ (printed vertically:) OUR TIME/ Interviews from/ THE EAST VILLAGE OTHER/ (horizontally:) publisher's device/ THE/ DIAL/ PRESS. Endpapers white.

Published Feb. 28, $1972 @ \$ 2.65 .75,000$ copies printed.

Contains "The Leary Dialogues," four interviews conducted by Allen Katzman, editor of East Village Other. The first interview ("In the Beginning," pp. 3-8) is with Gunther Weil and is about his relationship to Leary; the next three are with Leary: "Laughing Leary," pp. 9-13; "Come Together, Join the Party," pp. 14-22; "Hedonic Isolationism," pp. 23-29. Alex Bennett assists on the last interview. These interviews orginally appeared in East Village Other on Oct. 25, 1968 (D12); June 4, 1969 (D15); Jan. 12, 1971 (D20). 
(cover title:) Kunstmuseum/ Luzern/ Franz Gertsch/ 30 Januar 5-Marz 1972/ (three lines giving museum's hours)

$115 / 8 \times 81 / 4$ in. [162] pp., with three inserted color plates.

[1-4] advertisements; [5-7] essay about the artist by Jean-Christophe Ammann, followed by publication credits near the foot of p. [7] as follows: Impressum/ (rule)/ (C) Kunstmuseum Luzern (followed by address in two lines)/ (five lines of production credits); [8] photograph by Gertsch; [9] chronology and bibliography of Gertsch; [10] photograph of Leary with Sergius Golowin taken by Gertsch in 1971; [11-12] Timothy Leary about Franz Gertsch; [13] Timothy Leary uber Franz Gertsch (German translation of pp. [11-12]; [14-16] reproduction of two articles about Leary from Swiss press; [17] Gertsch photograph of Leary's astrological chart; [18-32] essays on Gertsch; [33-36] advertisements; [37-158] photoreproductions of Gertsch's works, including another one of Golowin and Leary on p. [83], with captions on alternate pages. Three colorplates inserted after pp. [78], [118], [124]; [159-62] advertisements.

White, stiff wrappers. Front cover: black and white photograph of Gertsch overprinted in pink with title (above). Spine: (printed vertically from bottom to top) KUNSTMUSEUM LUZERN 1972 FRANZ GERTSCH. Back cover blank.

Published Jan. 1972. Publishing records unavailable.

Contains "About Franz Gertsch," pp. [11-12], with German translation on p. [13], the first appearance of this piece.

Swiss author Sergius Golowin introduced Leary to the Swiss artist Franz Gertsch in 1971 while Leary was living in Switzerland in exile. Leary describes his impressions on viewing Gertsch's paintings: "He has clearly developed a new art form threatening and rapturous as any new vision of reality."

First edition:

THE UNDERGROUND/ READER/ Assembled by Mel Howard and The Reverend Thomas King Forcade/ (publisher's device)/ A PLUME BOOK from/ NEW AMERICAN LIBRARY/ (rule)/ TIMES MIRROR/ New York, London, and Scarborough, Ontario

$8 \times 53 / 8$ in. $x, 326$ pp. 
[i] blank; [ii-iii] title; [iv] (four lines regarding advances and royalties)/ Copyright (C) 1972 by Mel Howard and Thomas King Forcade/ All rights reserved/Library of Congress Catalog Card Number: 72-169000/ (publisher's device with three lines of trademark information)/ (eight lines naming publisher's affiliates)/ First Printing, March, 1972/ PRINTED IN THE UNITED STATES OF AMERICA; v-vi Forward!; vii-ix Contents; [x] blank; 1-4 Introduction; 5-322 text; [323] blank; [324-25] Listing of other PLUME BOOKS; [326] blank.

Stiff, white wrappers printed in black and orange. Front cover: publisher's device/ PLUME/ BOOKS/ Assembled by Mel Howard and the/ Reverend Thomas King Forcade/ THE UNDER-/ GROUND/ READER (followed by blurb which includes names of contributors) comic illustration of two men by R. Cobb. Back cover: SOCIOLOGY. Z5044. \$2.95/ THE/ UNDER-/ GROUND/ READER/ six-panel cartoon by R. Cobb/ publisher's series/ (printed vertically, at right:) COVER PRINTED IN USA. Spine: publisher's device/ (printed vertically:) THE UNDERGROUND READER/ Assembled by Mel Howard and the Reverend Thomas King Forcade/ 451-Z5044-295.

Published May $1972 @ \$ 2.95$. 7,500 copies printed.

Contains "God's Secret Agent," pp. 55-67, the first appearance in book form, reprinted from Other Scenes (C53), and "Letter from Timothy Leary," pp. 283-85, which had previously appeared in San Francisco Good Times (C70) and in the book Weatherman (B23).

“God's Secret Agent" is Leary's tribute to Augustus Owsley Stanley III, legendary 1960s West Coast manufacturer of LSD.

DER REISEWEG/THE ROUTE!

1972

First edition:

DER REISEWEG/ THE ROUTE/ (photo of artist)/ facsimile signature of artist Walter Wegmuller)/ EDITION/ GALERIE ORLY BALE/SUISSE/ (in four languages each of one line:) Third International Art Fair Basle/ Stand Nr. 13.286. 22.-26. Juni 1972/ (at right:) Art 3'72

Fold-out leaflet in seven sections, each measuring $81 \frac{1}{8} \times 41 \frac{1}{8}$ in., printed on both sides, making $14 \mathrm{pp}$.

[1] title; [2-8] reproductions of Wegmuller's paintings; [9-14] text.

Published June 1972 as a brochure for an art exhibit.

Contains an untitled critique of Wegmuller's paintings by "Prof. Timothy Leary und Brian Barritt," beginning at the bottom of p. [10] and ending on p. [12], in German and English. This is an important precursor of the theories presented in Neurologic (A13). 


\section{a. First edition:}

MYSTERY MAGIC/ \&/ MIRACLE/ Religion in a Post-Aquarian Age/ edited by/ Edward F. Heenan/ (publisher's device)/ A SPECTRUM BOOK/ PRENTICE-HALL, INC., ENGLEWOOD CLIFFS, N.J.

$8 \times 5 \frac{1}{2}$ in. xii, 180 pp.

[i] (seven lines about the editor); [ii] blank; [iii] title; [iv] (seven lines of LC publication data)/ ISBN 0-13-609032-X/ ISBN 0-13-609024-9 (pbk) / (two lines of cover credit)/ (C) 1973 by Prentice-Hall, Inc., Englewood Cliffs, New Jersey. A SPECTRUM/ BOOK. All rights reserved. (continues to end of line and following two with information about rights)/ 10987654321 / (five lines referring to publisher's offices)/ v-vi Contents; vii Preface; [viii] blank; [ix] dedication; [x] blank; [xi] Acknowledgments; [xii] blank; 1-179 text; 180 Notes on the Contributors.

Black, textured boards. Front cover blank. Back cover prints ISBN number at lower right. Spine printed vertically in gilt: Edited by/ HEENAN/ MYSTERY, MAGIC, AND MIRACLE/ Religion in Post-Aquarian Age/ (horizontally:) Prentice/ Hall. Endpapers white. Dust jacket white, printed in yellow, black, blue and gray. Front panel prints title and editor's name across photograph of the statue of St. Teresa by Bernini. Back panel carries reviews of other books. Spine prints title, editor's name and imprint.

Published Feb. 23,1973@ @5.95. Undisclosed number of copies printed.

Contains "The Religious Experience: Its Production and Interpretation," pp. 36-60. This is the first appearance in book form of Leary's Aug. 1963 address (AA43) in the form in which it appeared in Psychedelic Review, no. 3 (C30), except for minor revisions in the footnotes. (The text printed here is incorrectly referenced to Psychedelic Review, no. 4.)

\section{b. First (simultaneous) paperback edition:}

\section{$8 \times 5 \frac{1}{2}$ in.}

Collates identically with $\mathrm{B} 30 \mathrm{a}$.

Stiff paper wrappers. Front cover (identical to dust jacket of B30a): Mystery, Magic/ and Miracle/ Religion in/ a Post-Aquarian Age/ Edited by Edward F. Heenan/ (below:) photograph of Bernini's "Ecstasy of St. Theresa." Back cover: title, editor, blurb, publisher, ISBN no. Spine identical to B30a, except publisher's imprint changed to: S-294/ (publisher's device)/ A SPECTRUM BOOK.

Published Feb. 23, $1973 @ \$ 2.45$. Undisclosed number of copies printed. 
First edition:

IN SEARCH OF TIMOTHY LEARY: A PSYCHOHISTORICAL BIOGRAPHY/ A Dissertation/ Presented for the/ Doctor of Philosophy/ Degree/ The University of Tennessee/ Henry Marshall III/ August 1976

$11 \times 8 \frac{1}{2}$ in. viii, 132 leaves.

[i] title; [ii] Copyrighted by Henry Marshall III 1976/ All rights reserved; iii-iv Acknowledgments; v-vii Abstract; viii Contents; 1-15 Introduction; 6-111 text; 112 blank; 113-20 references; 121-30 Appendices; 131-32 Vita.

Orange paper wrappers, printed in black. Front cover: University of Tennessee logo / IN SEARCH OF TIMOTHY LEARY: A PSYCHOHISTORICAL BIOGRAPHY/ DOCTOR OF PHILOSOPHY IN PSYCHOLOGY/ HENRY MARSHALL III/ AUGUST 1976/ The University of Tennessee * Knoxville, Tennessee. Black spiral binding.

A small number of bound photocopies from typescript produced by the author in Aug. 1976 to satisfy his dissertation requirement. Not for sale.

Contains "Afterword by Timothy Leary," as Chapter 12, pp. 101-11. This is a letter written by Leary to Marshall critiquing Marshall's thesis on Leary, calling it the most successful of many such attempts. A note at the bottom of $p .101$ reads: "See Appendix G for discussion of this letter. The letter has been reproduced as nearly as possible to the original communication from Timothy Leary, received September 9, 1975."

First edition:

ALDOUS HUXLEY/ (rule)/MOKSHA/ Writings on Psychedelics and/ the Visionary Experience (1931-1963)/ (rule)/ Edited by/ Michael Horowitz \& Cynthia Palmer/ WITH INTRODUCTIONS BY/ DR. ALBERT HOFMANN AND/ DR. ALEXANDER SHULGIN/ (publisher's device)/ STONEHILL PUBLISHING COMPANY/ NEW YORK

$9 \times 6$ in. xxii, 314 pp.

[i] half-title; [ii] blank; [iii] title; [iv] Copyright $\odot 1977$ by Michael Horowitz and Cynthia Palmer/ (three lines giving publisher's address)/ (five lines regarding 
permission to reprint)/ The material included in MOKSHA was selected from the/ Aldous Huxley collection in The Fitz Hugh Ludlow Memorial/ Library, San Francisco, California/ ISBN: 0-88373-042-1/ LIBRARY OF CONGRESS CATALOG CARD NUMBER: 77-71224/ Book Design by Kenneth Miyamoto/ First Printing/ A FITZ HUGH LUDLOW MEMORIAL LIBRARY EDITION/ Printed in the USA; [v] acknowledgments; [vi] blank; [vii] dedication; [viii] blank; [ix-x] Contents; [xi] epigraph from The Mandukyopanishat; [xii] epigraph from Island; [xiii]-xv Preface; [xvi] blank; [xvii-xix] Introduction; [xx] blank; [xxi]-xxii Editors' Note; [1] section title; [2] blank; 3-314 text; [315-16] blank.

Brown cloth, stamped in silver on spine: (within rule frame) ALDOUS/ HUXLEY/ (printed vertically:) MOKSHA/ (below frame) HOROWITZ/ AND/ PALMER/ STONEHILL. White endpapers flecked with blue squiggles.

White dust jacket printed in black, with portions in red, orange, blue and green. Front panel prints text of title page above a profile drawing of a man's head containing a precious gem within a flower. Back panel contains two photographs of Huxley, information from title page, and partial list of chapter headings. Spine reproduces lettering of cloth spine.

Published Nov.1977@ @12.95.6,500 copies printed.

Contains "Mushrooms for Lunch," pp. 180-82, an extract from High Priest (A7), and "The Last Message of Aldous Huxley," pp. 294-98, an extract from Leary's editorial in Psychedelic Review, no. 3 (C29), its first book appearance. Four letters from Huxley to Leary (see J184) are reprinted here.

“Aldous Huxley's last message to the planet . . . [is] the utopian novel, Island . . . the climax of the 69 -year voyage of discovery. It is a great book. It will become a greater book."

Later editions of Moksha (London: Chatto \& Windus, 1980; Los Angeles: Tarcher, 1982; London: Penguin, 1983) delete "The Last Message of Aldous Huxley."

\section{a. First edition:}

(text of title framed by drawing of woman enclosing black circle) COSMIC/ TRIGGER / Final Secret of the Illuminati/ by Robert Anton Wilson/ Illustrated by John Thompson/ And/ (printed slash) Or Press • Berkeley • California $\bullet$ U.S.A.

$87 / 16 \times 5 \frac{1}{2}$ in. $x v i, 272 \mathrm{pp}$.

[i] half-title; [ii] blank; [iii] epigraph from Principia Discordia; [iv] Books by Robert Anton Wilson/ (twelve lines); [v] title; [vi] (C) 1977 by Robert Anton 


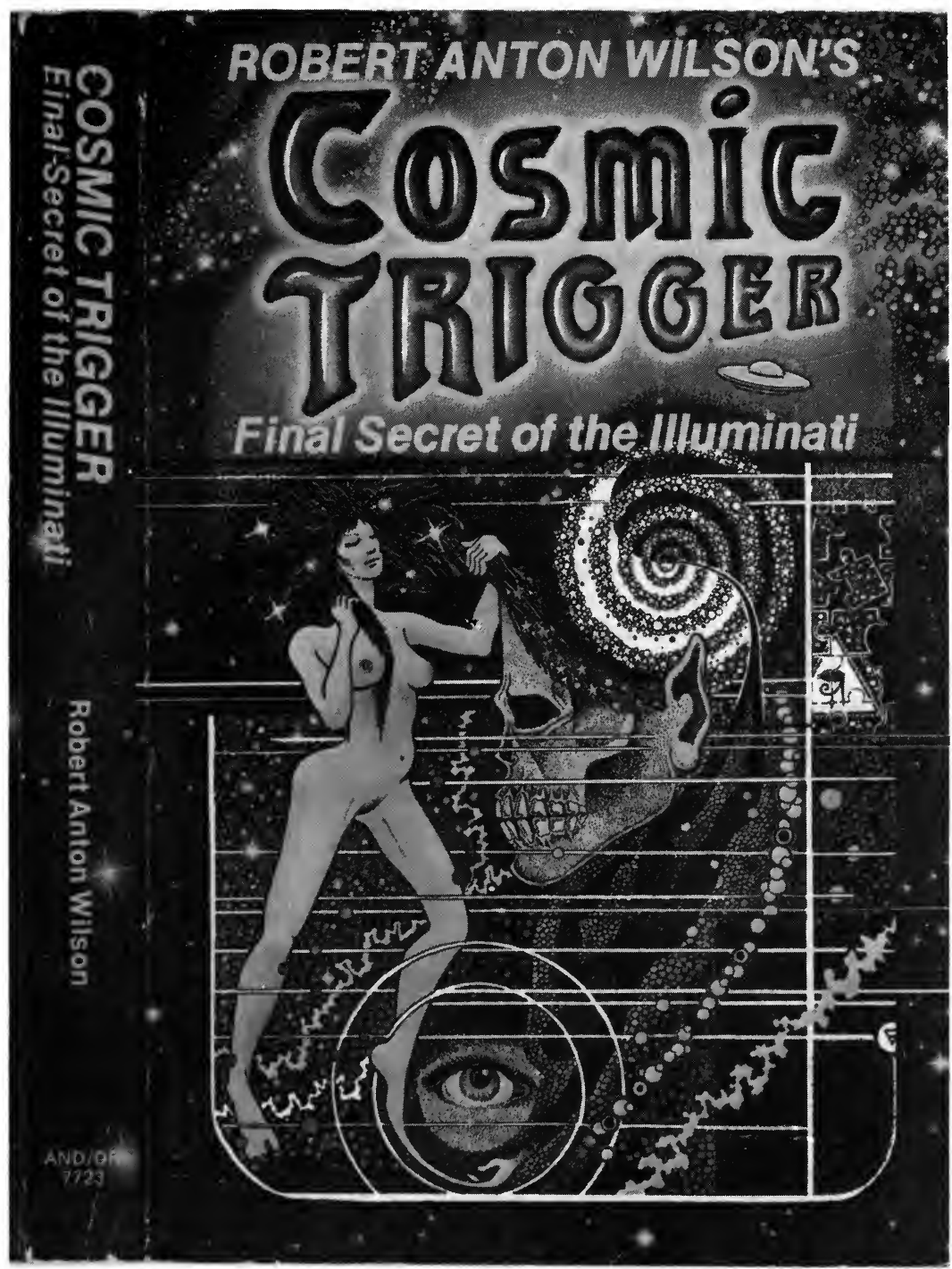

B33a: Leary introduced this work by his friend and sometime literary collaborator. Courtesy And/Or Press. 
Wilson/ Published and Distributed by/ And/Or Press/ Box 2246/ Berkeley, CA 94702/ ISBN: 0-915904-29-2/ Library of Congress Catalog Card No.: 77-89429/ (five lines of production credits)/ (four lines of appreciations); [vii] dedication; [viii-ix] Contents; [x] blank; [xi-xv] Forewords [sic] by Timothy Leary, Ph.D.; [xvi] blank; 1-269 text; [270-72] blank.

Multicolored, stiff paper wrappers illustrated by John Thompson. Front cover: ROBERT ANTON WILSON'S/ COSMIC/ TRIGGER/ Final Secret of the Illuminati. Back cover: $\$ 4.95 /$ (blurb within frame)/ publisher/ ISBN no. printed vertically at right. Spine: (printed vertically:) COSMIC TRIGGER/ Final Secret of the Illuminati/ Robert Anton Wilson/ (horizontally:) AND/ (printed slash) OR/ 7723.

Published $1977 @ \$ 4.95 .26,439$ copies printed.

Contains "Forewords," pp. [xi-xv]. “[Wilson] was the first . . . journalist who had actually read my writings and understood the steady development of my own research-from interpersonal psychology to interstellar neurogenetics."

\section{b. Second edition:}

ROBERT ANTON WILSON/ COSMIC TRIGGER/ THE FINAL SECRET/ OF THE/ ILLUMINATV/ Illustrated by/ John Thompson/ (publisher's device) A KANGAROO BOOK/ PUBLISHED BY POCKET BOOKS NEW YORK

$71 / 8 \times 41 / 8$ in. $x x x, 289 \mathrm{pp}$.

Text unchanged from B33a, except Leary's "Forewords" is changed to "Foreword," and "About the Author" now appears as last page of text. Copyright page [iv] reads in part: First Pocket Book printing March, 1978/ 1298.

Stiff, glossy white wrappers, printed in black and orange-yellow, with allegorical illustration in rainbow colors on front cover; blurb on back cover.

Published Mar.1978@ @1.95.100,000 copies reportedly printed.

\section{a. First edition:}

WORLDS/ BEYOND/ The Everlasting Frontier/ edited by/Larry Geis and Fabrice Florin/ with/ Peter Beren and Aidan Kelly/ And/Or Press/ 1978

$8 \frac{1}{2} \times 5 \frac{1}{2}$ in. $\times$ viii, 302 pp. 
[i] half-title; [ii] drawing by Geoff Chandler; [iii] title; [iv] (twelve lines of acknowledgments)/ Copyright (C) 1978 The New Dimensions Foundation/ Printed in U.S.A./ ISBN: 0-915904-36-5/ Library of Congress Catalog Card No.: 78-54345/ Published and distributed by/ And/Or Press/ P.O. Box 2246/ Berkeley, CA 94702/ First printing September 1978; v dedication; [vi] blank; vii-xii Foreword; xiii-xiv Preface; xv-xvii Contents; [xviii] drawing by Geoff Chandler; [1]-301 text; [302] ad.

Stiff paper wrappers with reproduction of painting of galaxies, stars and planets by Geoff Chandler across both covers, with lettering in red, yellow and purple. Front cover: the everlasting frontier/ WORLDS/ BEYOND/ edited by the New Dimensions Foundation. Back cover: \$6.95/ title/ blurb/ A New Dimensions Series Book/ And/Or Press/ ISBN no. printed vertically at right. Spine: (printed vertically:) WORLDS BEYOND New Dimensions Foundation/ (horizontally:) And/Or 7829.

Published Sept.1978@ \$6.95.10,000 copies printed.

Contains "Neuropolitics: The Meaning of Space Migration," on pp. 251-61. It is stated in the preface that "most of the material in this book has been transcribed and edited from conversations [New Dimensions Foundation has] broadcast on public radio stations." Leary is pictured addressing an audience at Space Day at the San Francisco Airport Hilton, Oct. 18, 1977, where he delivered this speech.

The text of this speech was prepublished in City Miner, no. 12 (C113a).

\section{b. Second edition:}

MOVING/ INTO SPACE/ The Myths and Realities/ of Extraterrestrial Space/ edited by/ Larry Geis and Fabrice Florin/ with/ Peter Beren and Aidan Kelly/ (publisher's device)/ PERENNIAL LIBRARY/ Harper \& Row, Publishers/ New York, Cambridge, Hagerstown, Philadelphia, San Francisco/ London, Mexico City, Sao Paulo, Sydney

$7 \times 4 \frac{1}{8}$ in. xviii, 302 pp.

Reduced, photo-offset reprint of B34a with new title. Collates identically except for copyright page [iv], which has variant text; last three lines read as follows: First PERENNIAL LIBRARY edition published 1980./ ISBN: 0-06-080499-8/ 808182838410987654321 . P 499 in Perennial Library series.

Stiff paper wrappers with reproduction of a painting of astronauts and spacecraft printed in blue and black across front cover, spine and half of back cover, text printed in red and black. Back cover contains quotations from reviews of original edition.

Published Jan. 30, $1980 @ \$ 2.50 .15,000$ copies printed. 


\section{a. First edition:}

GIGER'S/ ALIEN/ FILM DESIGN/ 20TH CENTURY FOX/ SPHINX VERLAG, BASEL

$113 / 4 \times 113 / 4$ in. $72 \mathrm{pp}$.

[1] title; [2] Copyright (C) 1979 Twentieth Century Fox Film Corporation/ Text copyright $\mathbb{C} 1979$ H. R. Giger/ 1979 Sphinx Verlag, Basel/ (three lines regarding rights)/ (five lines of credits)/ Printed in England: Import Litho (Woking) Ltd/ (two further lines of production credits)/ ISBN 3859146041 / CIP-Kurztitelaufnahme der Deutschen Bibliothek/ Giger, H. R./ (Alien)/ Giger's Alien: Filmdesign; 20th Century Fox/ (two lines of credits)/ Basel; Sphinx-Verlag, 1979/ (ISBN repeated)/ NE: Bonzanigo, Mia (Bearb.). (at right:) acknowledgments; [3] illustration; [4] Vorwort/ von Timothy Leary/ aus dem Amerikanischen von Dieter A. Hagenbach (consisting of three columns of text signed with facsimile signatures of Timothy and Barbara Leary, dated 5-23-79); 5-72 text.

Stiff, illustrated wrappers designed by Giger. Front cover: GIGER'S ALIEN/ (at left:) FILMDESIGN (at right:) 20TH CENTURY/ FOX. Inside front cover: photo of author. Back cover: publisher's imprint and ISBN. Inside back cover: data on author. Spine: (printed vertically from bottom to top:) SPHINX VERLAG GIGER'S ALIEN H. R. GIGER.

Published $1979 @$ SFr 39.80. 5,000 copies printed.

Contains the first appearance of Leary's foreword to the picture book of the science-fiction/ horror film Alien.

b. First English translation:

GIGER'S/ ALIEN/ FILMDESIGN/ 20TH CENTURY FOX/ BIG O PUBLISHING, LONDON

Same size and collation as B35a, differing (apart from language) only in the copyright page [2], which reads as follows: First published in 1979 by Big O Publishing Ltd/ (two lines giving London address and telephone/ American distribution by Big O Publishing/ (two lines giving Charlottesville, Virginia address and telephone)/ Copyright (C) 1979 Twentieth Century-Fox Film Corporation/ Text copyright (C) 1979 H. R. Giger/ (four lines of production 
credits)/ English translation by Hugh Young/ Printed in England by Import Litho (Tolworth) Ltd/ (four lines regarding production credits)/ (four lines regarding rights)/ ISBN 090566426 4/ (five lines of captions).

Covers similar to B35a, with minor changes including English publisher's name replacing that of Swiss publisher.

Published1979@£7.95.10,000 copies printed.

First edition:

THE/ PEOPLE'S ALMANAC/ PRESENTS/ (double rule)/ THE BOOK/ OF/ PREDICTIONS/ (double rule)/ BY/ DAVID WALLECHINSKY/ AMY WALLACE/ IRVING WALLACE/ WILLIAM MORROW AND COMPANY, INC./ NEW YORK 1980

$91 / 4 \times 51 / 2$ in. $x x, 524 \mathrm{pp}$.

[i] half-title; [ii] blank; [iii] title; [iv] Copyright $\odot 1981$ by David Wallechinsky, Amy Wallace, and/Irving Wallace/ (six lines pertaining to permission to reprint)/ Library of Congress Cataloging in Publication Data/ (eight lines of LC data, the last giving number ISBN 0-688-00024-X)/ Printed in the United States of America/ First Edition/ 123456789 10; [v] epigraph; [vi] blank; vii list of editorial staff members and contributors; [viii] blank; ix-xiv Contents; xv-xviii Welcome to the Future (introduction by the editors); [xix] fly-title; [xx] blank; [1] section title to Part I; [2] blank; 3-513 text; [514] blank; [515] Picture Credits; [516] blank; [517] About the Authors; [518-20] blank; [521] illustration; [522-24] blank.

White cloth spine stamped in gilt, gold board sides. Spine: (printed vertically:) The Book of Predictions/ DAVID WALLECHINSKY AMY WALLACE IRVING WALLACE/ (horizontally:) MORROW. Endpapers red. Dust jacket white and yellow printed in black and red. Front panel prints title and authors; Back panel contains publisher's blurb. Spine closely resembles book spine.

Published Nov. 1980. Undisclosed number of copies printed @ \$12.95.

Contains "Predictions" by Leary, pp. 10-12, with illustration captioned "Two hundred and fifty million people live on orbiting mini-earths." First appearance in print of these predictions. 
First edition:

MILLENNIUM/ Glimpses into/ the 21st Century/ Edited by/ ALBERTO VILLOLDO/ and KEN DYCHTWALD/ (publisher's device)/ J. P. Tarcher, Inc./ Distributed by Houghton Mifflin Company/ Boston

$9 \times 6$ in. xiv, 322 pp.

[i] half-title; [ii] blank; [iii] title; [iv] Library of Congress Cataloging in Publication Data/ (nine lines of data, ending): ISBN 0-87477-145-5/Copyright () 1981/ by Alberto Villoldo, Ph.D., and Ken Dychtwald, Ph.D./(10 lines pertaining to rights of reproduction)/ Library of Congress Catalog Card No.: 80-53147/ Designed by Barbara Monahan/ MANUFACTURED IN THE UNITED STATES OF AMERICA/ D 1098765432 1/ First Edition; [v] dedication; [vi] blank; [vii-viii] Contents; ix Acknowledgments; [x] epigraph; xi-xiv Introduction; 1-298, text; 299-307 Notes; [308] blank; 309-19 Index; [320-22] blank.

Stiff, black paper wrappers printed in white. Front cover: title printed vertically down the middle, with splashes of color and names of contributors and their subjects on left; at right: Glimpses/ into the/ 21st Century/ Original Essays/ by Eminent Thinkers/Explore the World/ of Tomorrow/ editor's names. Back cover: SOCIOLOGY \$8.95/ blurb/ Art direction: John Brogna/ Cover design: Cynthia Eyring/ Cover photo: Ken Rubin/ publisher and distributor; at right: ISBN within white square. Spine: (printed vertically:) VILLOLDO (rule) DYCHTWALD/ MILLENNIUM/ (horizontally:) publisher's device/ TARCHER/ rule/ HOUGHTON/ MIFFLIN/ COMPANY.

Published June1981@ \$8.95.7,500 copies printed.

Contains "Science" on pp. 277-98, preceded by a page containing a small photograph of Leary, a biographical sketch and a brief description of the scope of the article. After discussing "The Scientist As Hero," Leary describes the breakthrough work of "Eight Scientist Superstars," including John Lovelock, Lynn Margulis, Ilya Prigogine, Nelson Goodman, Gerard O'Neill, J. R. Chakraubarty, Ian Kennedy, Roy Walford and Edward Wilson.

a. First (trade) edition:

H. R. GIGER/N.Y. CITY (printed in white on black bar above photo of New York City and photo of author)/ UGLY PUBLISHING ZURICH

$155 / 8 \times 11$ in. $48 \mathrm{pp}$. 
[1] title; [2-3] double-page illustration; [4] Foreword by Timothy Leary dated Hollywood, June 1981 and printed in three columns; [4]-[48] illustrated text.

Glossy illustrated wrappers designed by author. Front cover: H. R. GIGER/ N.Y. CITY. Back cover: same text printed in black on white, with addition of publisher's name. Spine (printed vertically from bottom to top:) UGLY PUBLISHING ZURICH H. R. GIGER N.Y. CITY

Published $1981 @$ SwF 39.80.10,000 copies printed.

Contains "Foreword," p. [4], the first appearance of this text in any form.

\section{b. Simultaneous deluxe edition:}

A deluxe hardcover edition with identical collation was published simultaneously with B38a, limited to 450 copies (200 printed in English, 200 printed in German, and 50 printed in French). Price of German edition: SFr 90.00. Not seen. Information from publisher.

\section{a. First edition:}

The Great Books of/ Cannabis and Other Drugs/ or/ Researching the Pleasures/ of the High Society/ VOLUME I:/ Book II/ by Laurence Cherniak/ (plate identification and three-line caption for illustration occupying facing page and left one-third of title page)/ Cherniak (printed slash:)/ Damele Publishing Co., Oakland, California 96419

$93 / 4 \times 71 / 8$ in. xii, $208 \mathrm{pp}$.

2:i photographs and captions; 2:ii Preface; 2:iii general title to series; 2:iv-v Reviews of Book One; 2:vi Photographs and text Copyright (C) 1982 by Laurence Cherniak. ALL RIGHTS RESERVED. Abridged from The Great Books of Cannabis and Other Drugs by Laurence Cherniak. (continuing with 5 further lines of copyright information)/ (three-line disclaimer)/ ( 3 lines of publisher's address/ Printed in the United States of America by Enterprise Press Inc./ First Printing: Spring 1983 - 15,000/ (5 lines of information for ordering copies)/ (24 lines of credits)/ (to left: author and title of Books I \& II; to right: (softcover) ISBN 0-911093-02-8/ (hardcover) ISBN 0-911093-6/ all editions include index; 2:vii dedication and acknowlegments; [2:viii]-ix photo and title; 2:x-xi Contents; [2:xii] photo; 2:13-205 text; [2:206-7] index; [2:208] About the Author. 
Green cloth, lettered in gilt. Front cover: Laurence Cherniak/ The Great Books of Cannabis/ Volume I: Book II/ Marijuana Around the World, Sinsimilla, Stash, Opium. Spine (printed vertically): Laurence Cherniak THE GREAT BOOKS OF CANNABIS Volume I: Book II Cherniak/ Damele Pub. Co. Endpapers light green. Issued without dust jacket.

Published spring 1983 @ \$29.95. Undisclosed number of copies printed.

Contains "Preface," p. 2:ii, signed with Leary's facsimile signature.

\section{b. First (simultaneous) paperback edition:}

Collates identically with B39a.

$103 / 4 \times 81 / 2$ in.

Stiff paper wrappers, with overall reproduction of color photograph of a large field of mature marijuana plants, with colored mosaic border and text printed in white. Front cover: Laurence Cherniak/ The Great Books of Cannabis/ Volume I: Book II/ Marijuana Around The World, Sinsemilla, Stash, Opium/ (at bottom right) ISBN. Back cover: (at upper right) \$19.95 U.S./ author, title, blurb including quotation from Schultes' Introduction, imprint/ ISBN at right. Spine (printed vertically:) Laurence Cherniak THE GREAT BOOKS OF CANNABIS Volume I: Book II Cherniak (printed slash:)/Damele Pub. Co.

Published spring $1983 @ \$ 19.95$. 15,000 copies printed.

\section{First edition:}

Hohere Intelligenz \& Kreativitat/ Die Zukunst des Bewusstseins/ Ein wissenschaftliches Colloquium/ in UCSL's Kresge Town Hall-11. Juli 1981/ Einleitung und Moderator/ TIM LEARY/ Mit/ Paul Krassner/ Frank Barron/ Andrew Weil/ Walter Houston Clark/ Robert Anton Wilson/ John C. Lilly/ Michael Horowitz/ Francis Jeffrey/ Walter Schneider/ (publisher's device)/ Der Grune Zweig 80

$81 / 4 \times 53 / 4$ in. $36 \mathrm{pp}$.

[1] title; [2] blank; [3] DER GRUNE ZWEIG 80/ Protokoll des Colloquiums "Hohere Intelligenz und Kreativitat" anlasslich/ der Tagung DIE ZUKUNFT DES BEWUSSTSEINS in der UCSC Kresge Town/ Hall am Samstag, den 11. Juli 
1981 von 16.00 bis $18.00 \mathrm{Uhr} . /$ (six lines of acknowledgments and credits)/ Herausgeber: Werner Pieper-Die Grune Kraft-D-6941 Lohrbach/ ISBN 3-922708-80-3/ Erschienen anlasslich Tim Leary's erstem Deutschlandbesuch im Herbst 1982; 4-36 text.

White paper wrappers printed in blue against background of repeated publisher's name, stapled. Front cover: title and contributors' names above and below an abstract drawing of a brain incorporating images of people, the whole enclosed within a rule border; Back cover: abstract line drawing inset in upper third incorporating text: BRAIN-MIND-SPACE-TIME-CONTINUUM.

First appearance in book form and first translation of the remarks made at the panel on "Higher Intelligence and Creativity" at the Future of Consciousness symposium at the University of California-Santa Cruz, July 11 1981. Leary moderated the panel; his opening address occupies pp. 4-11; further remarks by Leary appear on pp. 30, 32-34, 35, 36. Leary's address and remarks originally appeared in English in High Times (C126).

Published autumn 1982 “on the occasion of Tim Leary's first visit to Germany in Autumn, 1982." Unknown number of copies printed.

First edition:

PSYCHEDELIC REFLECTIONS/ Edited by/ Lester Grinspoon, M.D./ and/ James B. Bakalar, M.D./ Both, Harvard Medical School/ Boston, Massachusetts/ (publisher's device to left) HUMAN SCIENCES PRESS, INC./ 72 Fifth Avenue/ NEW YORK, NY 10011

$9 \times 6$ in. 272 pp.

[1] half-title; [2] dedication; [3] title; [4] Copyright (C) 1983 by Human Sciences Press, Inc./ 72 Fifth Avenue, New York, New York 10011/ (three lines regarding rights)/ Printed in the United States of America/ 23456789 987654321/ (ten lines of LC publication data)/ ISBN 0-89885-129-7 AACR2; 5-6 Contents; 7 Acknowledgments; [8] blank; 9-10 list of contributors; 11-15 Introduction; [16] blank; [17] fly-title to Part One; 18-259 text; 260-65 Index; [266-72] blank.

Black leather, spine stamped in silver: Grinspoon/ Bakalar/ (printed vertically:) Psychedelic Reflections (horizontally:) publisher's device/ HUMAN/ SCIENCES/ PRESS/ INC. Endpapers white. Dust jacket black with overall grid design printed in pink, text lettered in white.

Published1983@ \$26.95. Undisclosed number of copies printed. 
Contains "Some Superficial Thoughts on the Sociology of LSD," pp. 32-38, the first appearance in print of this article.

"Every new technology which compels change in life-style or in view of human nature has always taken one generation to be socialized and domesticated. The more furious and extravagant the attacks on LSD, the more certain that an important mutational process was involved."

\section{First edition:}

Zukunsts/perspektiven (at right:) Forschung/ Szenarien/ Bewusstsein/ Morgen Kinder wird's was geben/ (square inset containing seven colored photographs) hrsg. Werner Pieper Der Grune Zweig 88 (cover title)

$115 / 8 \times 81 / 4$ in. $155 \mathrm{pp}$.

[3] epigraph above photograph (both printed in negative inside front cover); [4-5] contents; 6-7 notes on contributors; 8-155 text (concluding on inside back cover). Note: p. 105 contains production and copyright information, in two boxes: Impressum/ ZUKUNFTSPERSPEKTIVEN-Der Grune Zweig 88/ Redaktion: Konrad Volz, Nadina Leganovic, Werner Pieper/ (eleven further lines of production credits)/ Alle Rechte bei den Autoren/ Herausgeber: Werner Pieper-Die Grune Kraft/ D-6941 Lohrbach im Odenwald/ ISBN 30922708-88-9/ Second box contains twenty lines of copyright information under heading: QUELLEN.

Stiff silver wrappers. Front cover: reproduced as cover title, above; lettered in red and black, photographs in color. Back cover: title, publisher, blurb, ISBN, price. Spine (printed vertically, from bottom to top:) DER GRUNE ZWEIG 88/ (publisher's device)/ ZUKENFTSPERSPEKTIVEN (Morgen Kinder wird's was geben)/ Werner Pieper Hrsg.

Published $1983 @$ DM 19.80. Unknown number of copies printed.

Contains "Von Ost nach West bedeutet von der Vergangenheit in die Zukunft," p.61; "Hands On!," pp. 84-85. The former is reprinted from the German translation of Intelligence Agents (E31); the latter article is a transcription from the Transmitter Cassette, "Leary Live im Sauerland" (F27), and constitutes its first appearance in print. 


\section{First edition:}

(title framed by rule border at left and right:) DIGITAL/ DELI/ (bar at left third under which the text is framed by rules at left and right:) The/ comprehensive,/ user-lovable/ menu of/ computer lore,/ culture,/ lifestyles and/ fancy/ (short, thick rule)/ by The Lunch/ Group \& Guests/ (short, thick rule)/Edited by/Steve Ditlea/ (at right third of page framed within rule border at left and right:) Workman/ Publishing/ New York

$107 / 8 \times 81 / 4$ in. xvi, 384 pp.

[i] half-title; [ii] blank; [iii] title; iv Copyright $@ 1984$ by Steve Ditlea/ (four lines giving copyrights for two articles)/ All rights reserved./ (seven lines pertaining to rights of reproduction)/ (rule)/ (thirteen lines of Library of Congress cataloging data, ending:) 83-40030/ ISBN 0-89480-591-6/ (three lines production credits)/ (rule)/ Manufactured in the United States/ of America/ First printing September 1984/ 1098765432 1/ Workman Publishing Company, Inc./ 1 West 39 Street/ New York, New York 10018; v-x Menu [table of contents]; xi-xii Introduction; xiii-xv Rick Meyerowitz's Digital Deli Map of Personal Computer America; xvi blank; [1] fly-title to first section; [2] credits for photograph on p. [1]; 3-373 text; [374] blank; 375-76 Picture Credits; 377-82 Index; [383] blank; [384] illustration.

Stiff, glossy yellow wrappers lettered in black. Front cover: reproduces text and arrangement of title page (without publisher's imprint), with illustration to right in numerous colors of a "sandwich" made up of computer parts. Back cover: list and description of sections of book (headings in colors) and list of contributors; publisher's imprint, ISBN number and price at lower right. Spine: (printed vertically:) DIGITAL DELI by The Lunch Group \& Guests Edited by Steve Ditlea/ (horizontally:) publisher's device.

Published Dec. $1984 @ \$ 12.95 .40,000$ copies printed.

Contains "Personal Computers/ Personal Freedom," pp. 359-61, illustrated with three photographs including one of the author captioned: "Personal Telecommunication: Timothy Leary with a Coca Cola bottle telephone and an IBM PC." First appearance in print.

"I know now that our research with psychedelic drugs and, in fact, the drug culture itself was a forecast of or preparation for the personal computer age." 
First edition:

SPHINX 10 (number written one-half line higher, as "to the 10th power") (FAST)/ ALLES/ UBER/ (DIE)/ SPHINX/ Herausgegeben von/ Dieter A. Hagenbach/ und/ Hannes Bertschi/ 10 JAHRE SPHINX VERLAG BASEL

$611 / 16 \times 43 / 8$ in. $288 \mathrm{pp}$.

[1] half-title; [2-3] photograph; [4] blank; [5] title; [6] (ten lines of publishing information)/ (C) 1985 Sphinx Verlag Basel/ Alle Rechte vorbehalten/ (four lines of printing information) / Printed in Switzerland/ ISBN 3-85914-340-9; [7] publisher's note; [8-9] contents; [10] blank; [11]-21 publisher's foreword; [22] blank; 23-285 text; [286-87] photograph; [288] blank.

Stiff, glossy white wrappers. Front cover: title and subtitle surrounding a rainbow-colored triangle containing Sphinx device in apex. Back cover: list of contributors, publisher's device, ISBN, price. Spine: (printed vertically, from bottom to top:) SPHINX 10.

Published1985@SFr 10.00.10,000 copies printed.

Contains "Sphinx: Das Magazin des Jahrzehnts," pp. 106-10. Translated by Odette Brandli and Evi Glauser, this is the first publication of this piece in any language.

Leary pays tribute to the Sphinx publishing program and its influence on the cultural history of the decade, ending with mention of some famous Swiss nationals and exiles from other lands who found sanctuary there, as he did in the early 1970s.

B45

MCWILLIAMS PERSONAL COMPUTER BUYING GUIDE

First edition:

(within large decorative border from a 16th-century book:) The/ Peter/ McWilliams/ Personal/ Computer/ Buying/ Guide/ (in separate compartment:) Quantum Press/ Doubleday \& Company, Inc./ Garden City, New York/ 1985

$91 / 8 \times 6$ in. 448 pp. 
[1-2] quotations from reviews; [3] title; [4] (4 lines of production credits)/ Copyright (C) 1985 by Prelude Press/ All Rights Reserved/ Printed in the United States of America/ First Edition/ (four lines of reprint permissions)/ (six lines of LC publication data)/ ISBN 0-385-19688-1; [5] author's previous books; [6-9] Contents; [10]-15 Introduction; [16] illustration; 17-431 text; 432-39 Index; 440 mail order ad; 441-48 Addresses.

Stiff, white glossy wrappers, printed in black and a blend of primary colors. Front cover: Hardware, Software, Dinnerware/ Printers/ Peripherals, Parentheticals/ (within double-rule border:) 1985-86/ EDITION/ title in same format as title page. Back cover: price, blurb, partial list of contributors, illustrations, imprint, ISBN. Spine (printed vertically:) title in two lines, author, publisher, device.

Published $1985 @ \$ 12.95$. Unknown number of copies printed.

Contains "The New Literacy: Electronic Language. A Revisionist History of Publishing from the Standpoint of Electronic Books," pp. 421-31, its first appearance in print.

The revolutionary significance of the personal computer is seen against the background of book publishing since Gutenberg, followed by a description of the author's software design company and its initial product (see A26).

a. First ("regular") edition:

\section{BEST MINDS/ A TRIBUTE TO/ ALLEN GINSBERG/ EDITED BY BILL MORGAN/ \& BOB ROSENTHAL/ LOSPECCHIO PRESS/ NEW YORK/ 1986}

$10 \times 63 / 4$ in. $x v i, 312 \mathrm{pp}$.

[i] half-title; [2] reproduction of portrait of Allen Ginsberg by Naomi Ginsberg, c. 1948; [3] title; [iv] Copyright (C) 1986 by Bill Morgan and Bob Rosenthal/ ( 3 lines pertaining to reservation of rights)/ First Edition/ Book design by Tom Conomacos \& Bill Morgan/ Cover design by Bill Morgan/ (name and address of publisher in 4 lines); v Acknowledgements; [vi] blank; vii-ix Contents; [x] blank; xi editor's note; [xii] blank; xiii-xiv Introduction; [xv] reprints of Ginsberg's public school autograph book; [xvi] blank; 1-311 text; [312] limitation notice, as follows: This first printing of Best Minds is published on June 3, 1986 and is limited to an edition of 226 copies, 200 of which are numbered and signed by the editors and 26 of which are lettered $A$ to $Z$ and signed by the editors and Allen Ginsberg and contain an additional self-portrait photograph by the poet. In addition, 500 contributors' copies in special binding have been printed, 250 of which are numbered and 250 of which are hors commerce copies for the writers of these tributes. 
Red cloth printed and decorated in gilt. Front cover: BEST MINDS/ (rule)! illustration of three fish sharing one head. Spine (printed vertically between rules): MORGAN AND/ ROSENTHAL BEST MINDS A Tribute to Allen Ginsberg (printed horizontally:) Lospecchio. White endpapers.

Note: some copies contain an errata slip calling attention to the mis-identification of the author of "Allen's Phalanx," pp. 308-9. .

Published June 3, $1986 @ \$ 25$ in an edition of 500 copies, of which 250 are numbered and 250 copies are hors commerce for the contributors to the book.

Contains "For Allen Ginsberg," p. 168. Leary reminisces about Ginsberg's involvement in the early years of the Psychedelic Research Project at Harvard ("Allen was the signal I had been waiting for all my life").

b. First ("limited") edition:

Collates identically with B46a, except copies are signed by the editors.

Buckram.

Published June 3, $1986 @ \$ 75$ in an edition of 200 copies. Not seen: information from limitation notice and publisher's prospectus.

c. First ("deluxe") edition:

Collates identically with B46a, except copies are signed by the editors and contain an inserted signed self-portrait photography by Ginsberg.

Buckram.

Published June 3, $1986 @ \$ 125$ in an edition of 26 lettered copies. Not seen: information from limitation notice and publisher's prospectus. 


\section{BB.}

\section{Books with Reprinted Works}

First edition:

READINGS IN/ ABNORMAL/ PSYCHOLOGY/ by/ Lester D. Crow, Ph.D./ Alice Crow, Ph.D./ Brooklyn College/ 1958/ (publisher's device)/ LITTLEFIELD, ADAMS \& CO./ Ames, Iowa

$715 / 16 \times 47 / 8$ in. $x i i, 381[3$, blank] pp.

White, glossy wrappers lettered in black and brown over abstract design.

Littlefield College Outline series, no. 32. Published $1958 @ \$ 1.95$. Reprinted in 1960 , the place of publication having changed to Paterson, N.J.

Contains "Classification of Interpersonal Behavior into Sixteen Mechanisms or Reflexes," on p. 49 (erroneously listed in table of contents as p. 48), reprinted from "The Theory and Measurement Methodology of Interpersonal Communication" (AA12). This is the Interpersonal Check List with text describing its function.

BB2 INTERPERSONAL DYNAMICS

First edition:

INTERPERSONAL/ DYNAMICS/ Essays and Readings on Human Interaction/ WARREN G. BENNIS/ Professor of Industrial Management/ EDGAR H. SCHEIN/ Professor of Industrial Management/ DAVID E. 
BERLEW/ Assistant Professor of Industrial Management/ ALL OF/ MASSACHUSETTS INSTITUTE OF TECHNOLOGY/ AND/ FRED I. STEELE/ Assistant Professor of Industrial Administration/ YALE UNIVERSITY/1964/ THE DORSEY PRESS/ HOMEWOOD, ILLINOIS

$9 \times 6$ in. xvi, 763 [5, blank] pp.

Red and gray cloth lettered in gilt. Dust jacket not seen.

Published in $1964 @ \$ 11.95$. A second edition was published in $1968 @ \$ 15.75$; a third in $1973 @ \$ 14.50$.

Contains "How to Change Behavior," pp. 498-512, originally published in Clinical Psychology (B2); the text printed here follows that of the revised IFIF offprint (AA23d).

BB3 THE ECSTATIC ADVENTURE

First edition:

THE ECSTATIC/ ADVENTURE/Edited, with an Introduction and Notes by/ RALPH METZNER/ FOREWORD BY ALAN WATTS/ THE MACMILLAN COMPANY, NEW YORK

$83 / 8 \times 55 / 8$ in. xiv, 306 pp.

Black cloth, spine lettered in gilt with decorative motifs in red. Dust jacket black and white, printed in orange and yellow with abstract photographic illustration on front, blurb on back.

Published $1968 @ \$ 6.95$.

Contains reprints of two poems from Psychedelic Prayers (A5): "The Tree Above - the Tree Below" and "Prehistoric Origins of DNA" on pp. 138-39.

BB4 SMILING THROUGH THE APOCALYPSE

1970

\section{First edition:}

Smiling/ Through/ the Apocalypse/ (rule)/ Esquire's History of the Sixties/ The McCall Publishing Co./ New York

$$
9 \times 6 \text { in. xxiv, } 983 \text { pp. }
$$


Orange cloth, printed in black and white. Dust jacket printed in red, blue and black on white, with caricature drawing by David Levine on front and back panels and Leary's name listed among the contributors.

Published Mar.1970@\$12.50.

Contains "Turning On the World," pp. 589-99, a reprint of "In the beginning, Leary turned on Ginsberg and saw that it was good. . . . " from Esquire (C55), and previously reprinted in slightly revised form in High Priest (A7) as "Trip 6."

First edition:

VERDICT!/ the exclusive picture story of the trial of the Chicago 8/ drawings by VERNA SADOCK/ text by JOSEPH OKPAKU/ with the assistance of Ode Okore/ (device) THE THIRD PRESS/ Joseph Okpaku Publishing Company, Inc./ 444 Central Park West, New York, New York 10025

$12 \times 9$ in. $160 \mathrm{pp}$.

White, glossy stiff wrappers, lettered in black over drawings of Chicago 8 defendant Bobby Seale gagged and bound to a chair on front cover, Judge Julius Hoffman on back cover.

Published1970@\$3.95.

Contains brief excerpt from Leary's testimony as a defense witness in the trial of the Chicago 8, previously excerpted in The Tales of Hoffman (B19), but with a drawing of Leary on the stand by Verna Sadock that did not appear in the earlier Bantam edition.

First edition:

[double rule, top one thick]/ Toward Social Change/ a handbook for those who will/ edited by Robert Buckhout and/ 81 concerned Berkeley students/ [double rule, top one thin]/ [at right:] HARPER \& ROW, PUBLISHERS/ New York, Evanston,/ San Francisco, London 
Glossy gray and black, stiff wrappers. Front cover: title and authors printed in white on photograph of peace sign wall graffiti. Back cover: blurb. Spine: title, editors, publisher printed in white on black.

Published June 24, $1971 @ \$ 6.95$. A limited number of hardbound copies were published@\$14.95.

Contains "The Politics, Ethics, and Meaning of Marijuana," pp. 278-84. The article first appeared in The Marihuana Papers (B11).

\section{BB7 A COLLEGE LOOKS AT AMERICAN VALUES}

\section{First edition:}

A College Looks at/ American Values/ Volume I/ (ornament)/ Elwyn H. O'Dell, Editor/ Professor Of Political Science/ (at lower right:) Cover by William Dunning

$9 \times 6$ in. 376 pp.

Title-verso gives the following data: Copyright (C) 1971/ Central Washington State College/ Ellensburg, Washington/ Printed in the United States/ by/ Franklin Press, Inc./ Yakima, Washington.

Gray and purple, stiff paper wrappers, printed in yellow, tan, red and brown. Front cover: title above a drawing of two frogs held up by human hands. Title printed vertically on spine.

Published1971@\$7.00.

Contains "The Individual in the College Community: His Committment and His Work," pp. 95-104, with a photo of Leary on p. 67. This is a reprint, with minor revisions, of the paper presented at the Second Annual Symposium on American Values (AA40), also called, "Symposium '63: Man Thinking-The Idea of a College," and previously reprinted in The Politics of Ecstasy (A8)

\section{First edition:}

(printed in white on black:) Edited by David Horowitz, Michael Lerner, and Craig Pyes/ (printed in black on white in weaving letters:)/ counterculture/ and revolution/ (printed in white on black:) Random House (publisher's device) New York 
$91 / 4 \times 6$ in. xvii, 206 pp.

Stiff, white paper wrappers, with multi-color cartoonlike design printed on front cover and repeated on back, incorporating title and editor's names. Title, editors' names and publisher printed vertically on spine.

Published Feb.1972@\$3.50.

Contains "Manifesto" (i.e., Leary's prison escape letter) on pp. 67-68, preceded by a short biographical note on p. 66. This text previously appeared in book form in Weatherman (B23), as "Letter from Timothy Leary."

BB9 THE UNDERGROUND PRESS ANTHOLOGY

1972

First edition:

Underground/ Press/ Anthology/ edited by/ Thomas King Forcade/ (large black dot)/ ace books/ A Division of Charter Communications Inc./ 1120 Avenue of the Americas,/ New York, N.Y. 10036

$7 \times 4$ in. 192 pp.

Glossy, white paper wrappers printed in black, red and pink. Front cover: publisher's device, series number, price, title and editor's name surrounding a multicolored psychedelic playing card. Back cover: same illustration in miniature, with blurb. Spine lettered vertically with publisher's device, title, editor, number and price.

Published $1972 @ \$ 1.25$. Ace Books no.441-84490.

Contains "Deal For Real," pp. 12-19, which previously appeared in book form in Pot Art (B21).

BB10

DRUGS \& SEXUALITY

1973

First edition:

Edited by David Solomon/ and George Andrews/ Drugs and Sexuality/ Panther

$7 \times 43 / 8$ in. 431 pp.

Copyright page reads in part: Granada Publishing Limited/ First published in 1973 by Panther Books Ltd.,/ Frogmore, St. Albans, Herts. 
Stiff, aquamarine wrappers lettered in maroon. Front cover: title, names of contributors and editors, publisher's device and ISBN printed over a photograph of a nude woman reclining with a hookah. Back cover: blurb, prices in different British Commonwealth countries, ISBN. Spine not present on copy examined.

Published1973@75p.

Contains "She Comes in Colors," pp. 251-89, which was previously published in book form in The Playboy Interview (B15) and (under this title) in The Politics of Ecstasy (A8). The present printing contains the first appearance of an eleven-line footnote on p. 251 written by the author and largely concerning the various titles considered for the piece. Other contributors to this anthology include Boccaccio, Rabelais, Baudelaire, Cocteau, Anaïs Nin and Terry Southern.

BB11

SPIRITUAL COMMUNITY GUIDE

First edition:

(printed in calligraphic lettering and outlines:) spiritual community guide/ (illustration of an expanding rose)

$81 / 2 \times 51 / 2$ in. $192 \mathrm{pp}$.

Copyright page reads in part: Published in the USA by Spiritual Community Publications, Box 1080, San Rafael,/ California 94902 . . . / 1st Printing-June 1974.

Stiff wrappers colored pink, blue, green and yellow, lettered in yellow and purple. Front cover: new 1975-76/ spiritual community guide/ for north america/ introduction by ram dass. Back cover: price, ISBN, blurb, publisher, series, LC number. Spine: device, publisher and title printed vertically.

Published June1974@\$3.50.

Contains "Seed Transmission," p. 61, preceded by a full-page photograph of Leary, p. [60]. The text is a fragment from Terra II: The Starseed Transmission (A16). This volume is a guide to new spiritual organizations in the United States with photographs of spiritual leaders and one-page quotations from their writings. The Leary text is captioned: "Timothy Leary is an incarcerated visionary," a reference to the fact that Leary had been imprisoned since Jan. 1973. 
First edition:

MARIHUANA-HASHISH EPIDEMIC AND ITS/ IMPACT ON UNITED STATES SECURITY/ (double rule)/ HEARINGS/ BEFORE THE SUBCOMMITTEE TO INVESTIGATE THE/ ADMINISTRATION OF THE INTERNAL SECURITY/ ACT AND OTHER INTERNAL SECURITY LAWS/ OF THE/ COMMITTEE ON THE JUDICIARY/ UNITED STATE SENATE/ NINETY-THIRD CONGRESS/ SECOND SESSION/ (rule)/ MAY 9, 16, 17, 20, 21, AND JUNE 13, 1974/ Printed for the use of the Committee on the Judiciary/ (ornament)/ U.S.GOVERNMENT PRINTING OFFICE/ 33-371 0 WASHINGTON 1974/ (rule)/ For sale by the Superintendent of Documents, U.S. Government Printing Office/ Washington, D.C. 20402 - Price $\$ 4.00$

$9 \frac{1 / 4}{4} 6$ in. XX, $430, \mathrm{XXI} p p$.

Green wrappers lettered in black. Most of title-page text repeated on front cover; short-title printed on spine; back cover blank.

Published Oct.1974@ @ \$4.00.

Contains "Turn On/ Tune In/ Drop Out," pp. 422-23, reprinted from the Berkeley Barb, 20 May 1966 (C38).

BB13 THE WEATHER UNDERGROUND

1975

First edition:

THE WEATHER UNDERGROUND/ (short rule)/ REPORT/ OF THE/ SUBCOMMITTEE TO INVESTIGATE THE/ ADMINISTRATION OF THE INTERNAL SECURITY/ ACT AND OTHER INTERNAL SECURITY LAWS/ OF THE/ COMMITTEE OF THE JUDICIARY/ UNITED STATE SENATE/ NINETY-FOURTH CONGRESS/ FIRST SESSION/ (device)/ JANUARY 1975/ U. S. GOVERNMENT PRINTING OFFICE/ WASHINGTON: 1975 (cover title)

$91 / 8 \times 57 / 8$ in. vi, $169 \mathrm{pp}$.

White self wrappers, stapled. Title printed on front cover, as above; back cover blank. 
Published Jan.1975@\$2.30.

Contains excerpts from "Letter from Timothy Leary," p. 8, which previously appeared in San Francisco Good Times (C70) and other underground press publications, and was reprinted in Weatherman (B23). Here it is preceded by excerpts of "Communique No. 4" of the Weather Underground and other references to the Leary' prison escape.

BB14

THE HASHISH CLUB

1975

First edition:

THE HASHISH CLUB/ An Anthology of Drug Literature/ (asterisk)/ Volume Two/ THE PSYCHEDELIC ERA:/ FROM HUXLEY TO LENNON/ (asterisk)/ Edited by/ PETER HAINING/ (publisher's device)/ PETER OWEN. LONDON

$87 / 16 \times 53 / 8$ in., 160 pp.

Copyright page reads in part: First British Commonwealth edition 1975.

Orange, textured boards; spine stamped (vertically) in silver: Peter Haining/ THE HASHISH CLUB/ (thick rule)/ Two/ (printed horizontally:) (device)/PETER/ OWEN. Graphic design on endpapers. Dust jacket white, printed in maroon and orange. Title, subtitle, editor on front; list of contributors on back; title, editor and publisher on spine.

Published Mar. 20, $1975 @ £ 3.25$.

Contains "LSD Is Air," pp. 48-49. This is a reprint of a portion of Trip 16 of High Priest (A7), and the first appearance under this title. It is preceded by a biographical sketch of Leary ("the most famous name connected with drugs in the present time") by the editor, pp. $46-47$.

First edition:

The Metaphors of/ Consciousness/ Edited by/ Ronald S. Valle/ Center for the Development of/Consciousness and Personal Growth/Wexford, Pennsylvanial and/ Rolf von Eckartsberg/ Duquesne University/ Pittsburgh, Pennsylvanial Plenum Press • New York and London 
$91 / 4 \times 57 / 8$ in. xxii, $521 \mathrm{pp}$.

Blue cloth, spine lettered (vertically)in gilt: Valle • von Eckartsberg/ (rule)/ The Metaphors of Consciousness/ (horizontally:) Plenum. Purple dust jacket printed in gold and white, with title and large mandala design on front panel; publisher's ads on back panel.

Published $1981 @ \$ 29.50$.

Contains "Exo-Psychology," pp. 179-97. At foot of p.179: "This chapter first appeared as chapters 1 to $6,13,23,24,25$, and 28 in Leary (1977). They are reprinted here (with revisions) with permission of the publisher." See A19 for earliest version. 


\section{C. \\ Journals and Magazines with Contributions}

\section{7}

C1 Sports columns. The Classical Recorder. Springfield, Mass., 1936-37. As sports editor of the Classical High School newspaper, Leary contributed numerous columns on sports events during the school year.

\section{8}

C2 Reportage and editorials. The Classical Recorder. Springfield, Mass., 1937-38. As editor in chief of his high school newspaper, Leary published frequently in its pages during his senior year.

\section{6}

C3 "Progress Toward Solving the Problem of Race Relations." School and Society 64, no. 1647 (July 20): 41-43. Coauthored with T. H. Kennedy. See AA2 (offprint form).

\section{7}

C4 "Communist Thought on the Negro." Phylon 8, no. 2 (after July): 116-23. Coauthored with T. H. Kennedy. See AA3 (offprint form). 
C5 "Introduction; Psychological Service and Research; Problems in Collaboration; A Technique of Group Psychotherapy; Results and Implications of the Group Therapy Program; Social Implications of the Group Therapy Situation; Concluding Commentary." J. Social Issues 6 , no. 1:2-4, 14-64. Introduction and five articles coauthored with Hubert Coffey, Mervin Freedman, and Abel Ossorio. Front cover issue title: Community Service and Social Research-Group Psychotherapy in A Church Program. Among the objectives stated by the authors in the Introduction are to test the interpersonal concepts of Harry Stack Sullivan, develop a methodology to categorize interpersonal relations, study projective methods of prediction, observe social interaction and develop a method of group therapy.

C6 "Patterns of Social Interaction and Their Relation to Personality Structure." American Psychologist 5, no. 7 (July):303. Coauthored with Abel Garcia Ossorio. Abstract of paper presented at the annual meeting of the American Psychological Association. "This paper reports the findings concerning the relationships existing between social interaction patterns in a group therapy situation and individual personality structure revealed by other data."

\section{1}

C7 "Measurement of the Group Process and the Nature of Therapeutic Improvement in Group Psychotherapy." American Psychologist 6, no.9 (Sept.):499. Coauthored with Mervin B. Freedman, Hubert S. Coffey, and Abel G. Ossorio. Abstract of paper presented at the annual meeting of the Western Psychological Association. "The rated interpersonal behavior of seven patients during 48 hours of group therapy."

C8 "The Interpersonal Dimension of Personality." J. Personality 20, no. 2 (Dec.):143-61. Coauthored with Mervin B. Freedman, Abel G. Ossorio and Hubert S. Coffey. See AA7 (offprint form).

\section{4}

C9 "The Prediction of Interpersonal Behavior in Group Psychotherapy." Group Psychotherapy VII, no. 1 (May):7-51, with twelve text figures. Coauthored with Hubert S. Coffey. See AA9 (mimeograph and offprint forms). 
C10 "The Interpersonal Dimension of Personality: II. An Objective Study of Repression." J. Personality 23, no. 2 (Dec.):131-53. Coauthored with Rolfe LaForge, Herbert Naboisek, Hubert S. Coffey and Mervin B. Freedman. See AA10 (offprint form).

\section{5}

C11 "Interpersonal Diagnosis: Some Problems of Methodology and Validation." J. Abnormal \& Social Psychology 50, no. 1 (Jan.):110-24. Coauthored with Hubert S. Coffey. See AA11 (offprint form).

C12 "The Theory and Measurement Methodology of Interpersonal Communication." Psychiatry 18, no. 2(May):147-61. A description of "some methods that the Kaiser Foundation has developed for isolating and defining human interactions. Two theoretical implications are "the principle of self-determination" and "the principle of reciprocal interpersonal relations." Not seen in offprint form.

C13 "Changes in Psychoneurotic Patients With and Without Psychotherapy." J. Consulting Psychology 19, no. 4 (July):239-45. Coauthored with Frank Barron. See AA13 (offprint form).

\section{6}

C14 "A Methodology for Measuring Personality Changes in Psychotherapy." J. Clinical Psychology XII, no. 3 (Apr.):123-32. Coauthored with Joan Harvey. See AA14 (offprint form).

C15 "A Theory and Methodology for Measuring Fantasy and Imaginative Expression." J. Personality 25, no. 2 (Dec.):159-75. See AA15 (offprint form).

\section{0}

C16 "Huck and Jim in Their Interpretive Balloon." Contemporary Psychology 5, no. 10 (Oct.):337-38. Review of Scoring Human Motives: A Manual by John Dollard and Frank Auld, Jr. New Haven: Yale University Press, 1959. 
C17 "Letter to the Food \& Drug Administration." Newsletter \# I [of the] Research Program on Consciousness-Altering Substances (Feb.):10-11. A summary (dated Jan. 26, 1962) of the research activities of the Harvard Psychedelic Project as justification for receiving psychedelic substances from Sandoz, Inc. Other portions of this newsletter probably were written by Leary.

C18 "Interpersonal Behavior and Behaviorism." U.S. Veterans Administration Bulletin (1962). Reprint of paper read at Seventh Annual Research Conference on Chemotherapy Studies in Psychiatry, Cincinnati, Mar. 27, 1962. Not seen. See AA29 (mimeograph form).

C19 "The Politics of the Nervous System." Bulletin of the Atomic Scientists 18, no. 5 (May):26-27. Coauthored with George Litwin, Michael Hollingshead, Gunther Weil and Richard Alpert. Response to an article published in this journal, "Psychochemicals as Weapons" by E. James Lieberman. "The author . . . has mixed together an astonishing combination of psychiatric folklore and chemical warfare fantasy." See J24 and $\mathbf{J} 25$ for further responses.

\section{3}

C20 "Drugs and Freedom-an Academic Question." Esquire (Feb.). Coauthored with Richard Alpert. Further response to Martin Mayer's "Getting Alienated with the Right Crowd at Harvard" (J33).

C21 "Religious Implications of Consciousness Expanding Drugs." Religious Education (May-June):251-56. Coauthored with Walter Houston Clark. See AA41 (mimeograph and offprint forms).

C22 "The Politics of Consciousness Expansion." Harvard Review I, no. 4 (Summer):33-37. Coauthored with Richard Alpert. There were two printings of this issue: the second is so designated on the contents page. See AA42 (offprint form).

C23 Letter to the Editor. Reporter (Sept.):12. Response to article, "Hallucinogenic Drug Cult" (J32) published one month earlier.

C24 "Hermann Hesse: Poet of the Interior Journey." Psychedelic Review, no. 2 (Fall):167-82. Coauthored with Ralph Metzner. "Hesse is the master guide to the psychedelic experience and its application. Before your LSD session, read Siddhartha and Steppenwolf." 


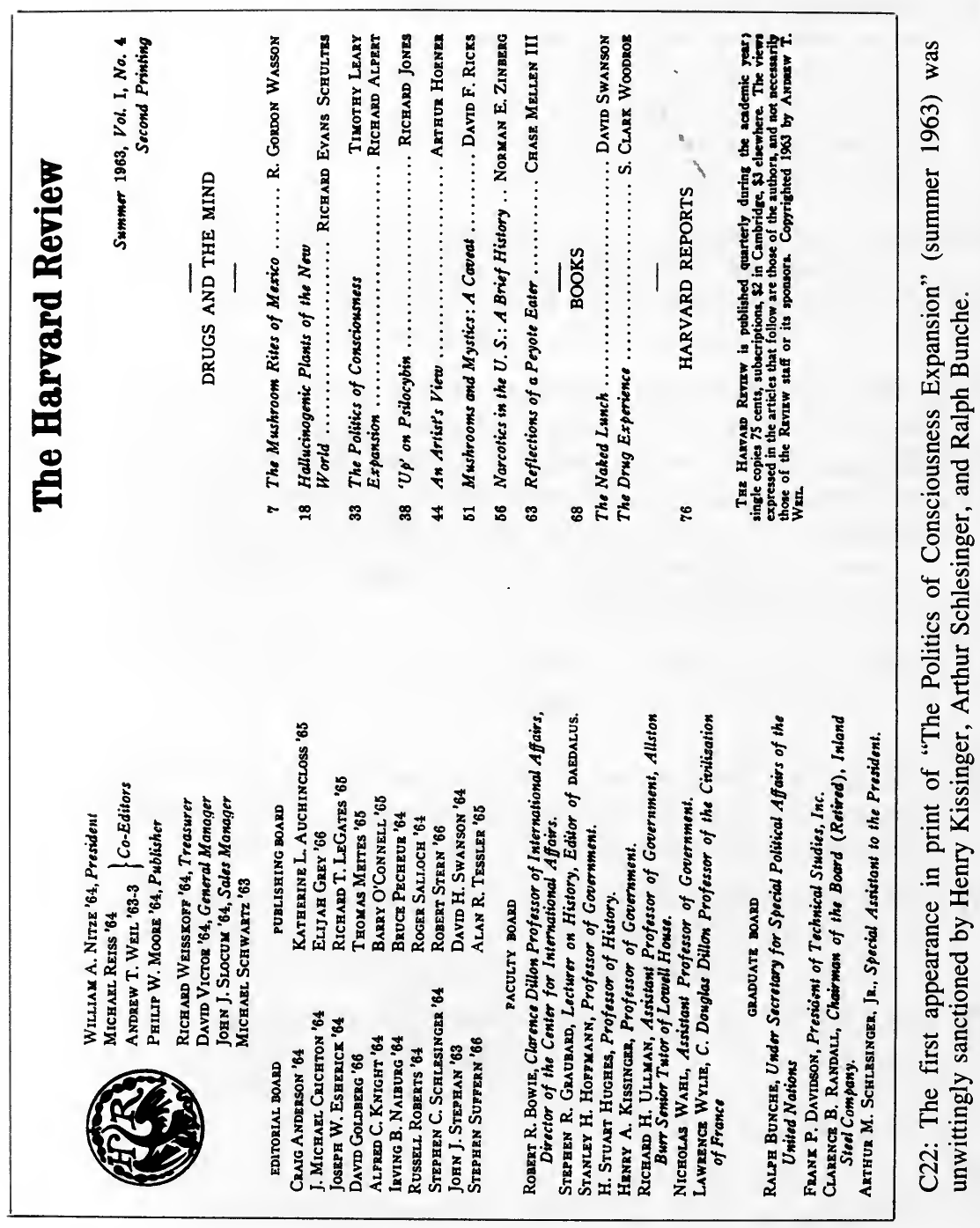


C25 Editorial contributions. IFIF Newsletter I, nos. 1-3 (May-Nov. 1963). Leary wrote much of the contents of this newsletter, a publication of the International Federation for Internal Freedom. He was also an editor and member of the IFIF board of directors.

C26 "Reactions to Psilocybin Administered in a Supportive Environment." J. Nervous and Mental Disease 137, no. 6 (Dec.):561-76. Coauthored with George H. Litwin and Ralph Metzner. See AA45 (offprint form).

C27 "Some Cool Thoughts on a Hot Issue." Esquire (Dec.). Coauthored with Richard Alpert and Ralph Metzner. Response to article published by Martin Mayer (J33). A longer version of this text was published in Politics of Ecstasy (A8).

\section{4}

C28 Letter to the Editor. Playboy (Feb.):5. Coauthored with Richard Alpert and Ralph Metzner. In praise of the Nov. 1963 issue on psychedelic drugs.

C29 "The Last Message of Aldous Huxley." Psychedelic Review, no. 3 (Spring):267-74. "Aldous Huxley's last message to the planet [is] in the form of the utopian novel, Island. Like all great books it is misunderstood in its time because it is so far in front of its time."

C30 "The Religious Experience: Its Production and Interpretation." Psychedelic Review, no. 3 (Spring):324-46. First periodical appearance. See AA43 (mimeograph form). Reprinted in $J$. Psychedelic Drugs 3, no. 1 (Sept. 1970), and Peter Marin \& Allan Y. Cohen, Understanding Drug Use (New York: Harper \& Row, 1970), pp. 143-45.

C31 “The Religious Experience: Its Production and Interpretation." A Way Out 20, no. 5 (May/June):150-57. A revised and considerably shortened version of AA43 and C30. Reprinted in this format in Green Revolution 10, no. 5/6 (Summer 1972):12-14.

C32 [Title unknown]. Bulletin of the Massachusetts Psychological Association (1964?). Behind the politics of the "psilocybin affair" at Harvard. Not seen (information from unpublished checklist).

\section{5}

C33 “A New Behavior Change Program Using Psilocybin." Psychotherapy: Theory, Research and Practice 2, no. 2 (July):61-72. Coauthored with Ralph Metzner, et al. See AA44c (offprint form). 
C34 "Use of Psychedelic Drugs in Prisoner Rehabilitation." British Journal of Sociology 2 (1967-68):27-51. Coauthored with Ralph Metzner. "A lengthier review of the project discussed in Leary et al. 1965. The authors offer a theory of reform through detachment from learned social roles [with] some suggestion of a lower than average recidivism rate in the group treated with psilocybin" (L. Grinspoon and J. Bakalar, Psychedelic Drugs Reconsidered, p. 364).

C35 "Languages: Energy Systems Sent and Received." ETC. 22, no. 4 (Dec.):431-60. See AA46 (offprint form).

\section{6}

C36 "Five Psychedelic Prayers Adapted from the Tao Te Ching." Psychedelic Review, no. 7 (Spring):11-19. An earlier and considerably different version of the foreword and five poems from Psychedelic Prayers (A5).

C37 "The Experiential Typewriter." Psychedelic Review, no. 7 (Spring):70-85. Description of a "communicating device" designed for use in psychedelic and similar states. A note at the end describes this article as a chapter from a forthcoming book, Tranart-The Communication of the Ecstatic Experience. (This book was not published.)

C38 “Turn On, Tune In, Drop Out." East Village Other (May-June). First of a series of three columns, constituting a primer on the meaning behind this slogan. Reprinted in Berkeley Barb and other underground publications, and in book form in Marihuana-Hashish Epidemic (BB12).

C39 "The Politics and Ethics of Ecstasy." Cavalier (July):35-37, 50, 52. Transcript of a speech delivered at Town Hall, New York City, about the current situation concerning LSD, with remarks about levels of consciousness.

C40 "The Second Fine Art: Neo-Symbolic Communication of Experience." Psychedelic Review, no. 8 (Fall):9-32. Use of the "cut-up" method of writing developed by William Burroughs and Brion Gysin to create combined texts of Herman Hesse and Arthur Koestler with Harvard psychedelic session reports.

C41 "Programmed Communication During Experience with DMT (Dimethyltryptamine)." Psychedelic Review, no. 8 (Fall):83-95. Comparison of DMT with LSD and a detailed description of author's DMT experience using the "experiential typewriter." 


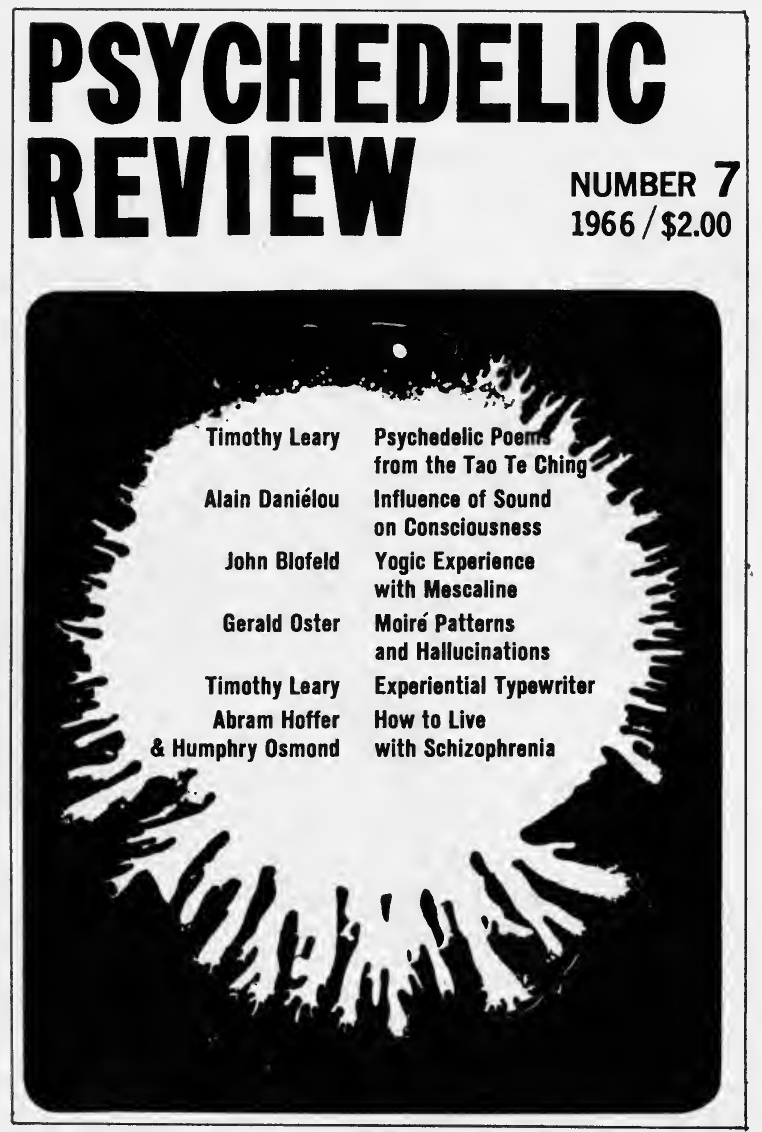

C36-37: Leary was an editor and frequent contributor to the first journal devoted to psychedelic experience. Courtesy Timothy Leary.

C42 "Turn On, Tune In, Drop Out." Innerspace 1, no. 1 (Oct.)7-8. Subtitled "Column III: Basic "Turn On" Methods." On the chemical basis of consciousness and methods of "turning on" at different levels of awareness. Reprinted in Berkeley Barb (Dec. 16, 1966):7, and elsewhere.

C43 Statement presented at press conference at the Fairmont Hotel, San Francisco, Dec. 12, 1966. City of San Francisco Oracle, no. 4 (Dec.):1-2, 15-17. About the "psychedelic religious movement" and the founding of the League for Spiritual Discovery. Leary's statement is followed by a question-and-answer session, with Richard Alpert also participating. 
C44 "The Great Millbrook Snot Bust." East Village Other (Dec.). Description of the latest raid by the sheriff's department on the Millbrook commune. Reprinted in The Boo Hoo Bible (B25).

C45 "League [League for Spiritual Discovery] Fact Sheet." Innerspace, no. 2 (Dec.):[22]. Leary was one of the main authors of this statement, which deals with the purposes, methods, administrative structure and legal structure of the newly founded League for Spiritual Discovery.

\section{7}

C46 "Changes." City of San Francisco Oracle, no. 7 (Apr.):3, 5-15, 26-35. First printing (of three); in second and third printing, text appears on pp. $2-3,6-17,29-34,40-41$; in third printing there is a copyright symbol, absent here, before the photographer's name on p. 2. (See: George Dowden, A Bibliography of Allen Ginsberg, p. 94, for more details on this item.) Text of a discussion among Leary, Alan Watts, Allen Ginsberg and Gary Snyder, which took place on Watts's houseboat in Sausalito on Feb. 5, 1967, with numerous photographs of the participants. More than 100,000 copies of this issue of the Oracle were printed.

C47 “The Leary-Lettvin Debate." Innisfree 3, no. 6 (May 3):3-10, 13-23. Special supplemental issue, completely dedicated to the debate. Includes talks, questions and answers and an interview.

C48 "Start Your Own Religion." Southern California Oracle, no. 1 (May). Excerpts from book of the same title (A6) published about this time.

C49 "Laughing Religion: The Neo-American Church Catechism and Handbook." East Village Other 2, no. 19 (Aug. 19-Sept. 1):10-11. Review of Art Kleps's The Boo Hoo Bible (1967). This review was published at approximately the same time in History of the Psychedelic Movement Cartoon \& Coloring Book (B13); it was reprinted in the second edition of The Boo Hoo Bible (B25).

C50 "You Are a God, Act Like One!" The Mile High Underground (Fall). Reprinted in International Times, no. 25 (Feb. 2, 1968), and elsewhere. On "tuning in," the second of the three-part column explaining the slogan Turn On, Tune In, Drop Out. Probably published originally in 1966.

C51 "On Programming Psychedelic Experiences." Psychedelic Review, no. 9:5-19. Coauthored with Ralph Metzner. Programming strategies with examples from tantric psychology and the peyote ceremony, with four full-page illustrations. 


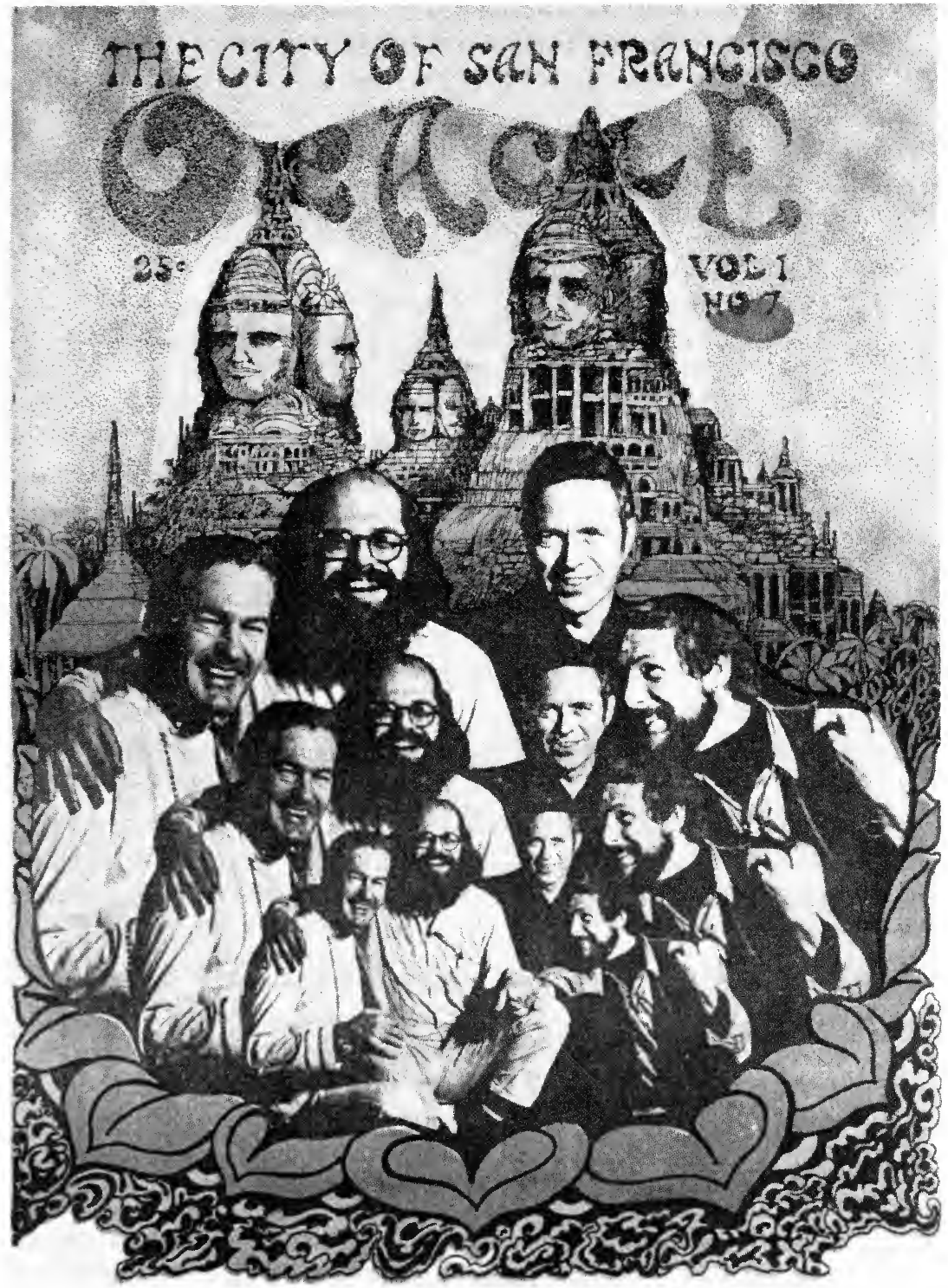

C46: First printing of the complete text of this seminal 1967 discussion of counterculture ideals amongst Leary, Allen Ginsberg, Alan Watts and Gary Snyder. Courtesy Allen Cohen. 
C52 "Homage to the Awe-Full See-er." Psychedelic Review, no. 9 (Fall):59-66. First appearance of this poem. Reprinted in Politics of Ecstasy (A8).

\section{8}

C53 “God's Secret Agent A.O.S.3." Other Scenes, no. 1 (Mar.):[3-4, 14]. Account of Leary's meeting with the preeminent "psychedelic drug outlaw," LSD manufacturer Augustus Owsley Stanley III, and his reflections on other "acid alchemists." Reprinted in Berkeley Barb (Mar. 22-28, 1968) with the name "A.O.S.3" changed to ".0025"; Orpheus 1, no. 3 (1968); Other Scenes (Oct. 1970) under title, "The Cosmic Courier"; High Times, no. 42 (Feb. 1979); Politics of Ecstasy (A8).

C54 "How Merry Jerry's Yip Stopped The War." Berkeley Barb (May 24-30):12-13; (May 31-June 6):12-13. Two-part article on the Yippies, the antiwar movement and the Democratic presidential candidates.

C55 "In the Beginning, Leary Turned on Ginsberg and Saw That It Was Good . . . And Then Leary and Ginsberg Decided to Turn on the World." Esquire (July):83-86; 116-17. Memoir of Allen Ginsberg's first LSD trip in Cambridge, Mass. Reprinted in slightly revised form in High Priest (A7), and in its present form in Smiling through the Apocalypse (BB4).

C56 “The Magical Mystery Trip." Evergreen Review, no. 56 (July):56-61, 82-83. On the influence of British writers, philosophers, scientists and musicians on the psychedelic movement. Reproduction of full-page portrait of Leary by Paul Davis on p. 56. Reprinted in Politics of Ecstasy (A8) in slightly revised form, and in Running Man 1, nos. 3-5 (1969).

C57 "Declaration of Evolution." Anonym Quarterly (Fall):10-18. A manifesto for the psychedelic generation, modelled on the Declaration of Independence. This text appeared as the final chapter in Politics of Ecstasy (A8) at about the same time, and later in pamphlet form (A10). A shorter version was published in Harbinger (C57a).

C57a "Government Violations and the Non-Violent Hippies." Harbinger (after July): 17-19. Slightly altered version of text published about the same time in Alternatives to Violence (B16), with different title. See also C66. 
C58 "Poems on the Conduct of Life for Barbara and Chuck." East Village Other (Jan. 17):12. Coauthored with Rosemary Leary. Six poems adapted from translations of the Tao Te Ching, Book II, chapters 41-45, and thus a continuation of Psychedelic Prayers (A5), which is based on Book I.

C59 Letter to the Editor. Playboy (Mar.):9. Written in praise of Eldridge Cleaver.

C59a "Bread of the Gods." Circular Causation, no. 1 (Spring): printed on two inserted half-leaves bound in center of magazine. Greatly altered version of the poetic writing in High Priest (A7), Chapter 2: apparently the unedited text ("the entire poem . . . runs some 48 pages"-author's printed note).

C60 "What Kind of Party Do You Want?" Los Angeles Free Press (July 25):5. A radical program for political change, based on counterculture values; a platform for Leary's candidacy for governor of California.

C61 “Deal for Real." East Village Other (Sept.):43. First publication of this article written in tribute to psychedelic chemists and entrepreneurs, placing them in tradition of alchemists, herbalists and shamans. Widely reprinted in the underground press, and cited by the California judge as a reason to deny the author bail in Mar. 1970.

C62 “Episode and Postscript." Playboy (Dec.):221-24, 226, 312-20. Detailed account of the arrest of the Leary family in Laredo for marijuana possession, and their subsequent legal problems. Illustrations by Ron Rae include a "pop-up" of Leary smoking a hookah.

C63 "Statement on Speed." First Vibrations (1969):4-5. On the dangers of using amphetamines. Reprinted in Countdown, no. 3 (1970).

C64 "The Effects of Consciousness-Expanding Drugs on Prisoner Rehabilitation." Psychedelic Review, no. 10 (1969):29-44. First appearance under this title of Chapter 9 of High Priest (A7), with text slightly altered.

\section{0}

C65 Review of Futz. Rolling Stone, no. 50 (Jan. 21). Leary's review of the controversial play by Rochelle Owens.

C66 "Violence is Killing by Machines at a Distance." Countdown, no. 1 (Feb.):29-9 (pages are numbered backwards). Reprinted from an 
altered and apparently earlier version of "Violent Governments, Nonviolent Hippies" (B16). Attribution is to San Francisco Oracle but this version first appeared in Harbinger (C57a).

C67 "Message from Leary." East Village Other (Apr. 21):2. Written in a California prison.

C68 "Incident of Violence Avoided." Rolling Stone (May 14):27. Description of an incident in California State Prison, San Luis Obispo.

C69 "Tim Leary, Appellant V. State of California, Appellee." East Village Other (July 21):3. First publication of the "Eagle Brief," later published in book form (A11). Reprinted in Psychedelic Review, no. 11 (1971).

C70 "Letter from Timothy Leary." San Francisco Good Times (Sept. 18). First publication of Leary's prison escape letter (written Sept. 12). Printed (simultaneously?) in Los Angeles Free Press (Sept. 18-24):1 (where it is stated that a copy of the text was received "in a plain brown envelope bearing no return address" on Sept. 16). Also appearing is a letter from the Weatherman Underground dated Sept. 15, signed by Bernadine Dohrn taking credit for Leary's escape. Reprinted widely in the underground press, in Psychedelic Review, no.11 (1971), in Weatherman (B23), and in The Weather Underground (BB13).

C71 Letter from Algeria to editor Jaakov Kohn. East Village Other (Oct. 20):2. Cowritten with Rosemary Leary. About Weatherman and the Third World.

C72 Letter from Algeria to editor Jaakov Kohn. East Village Other (Nov. 24):2. Explanation of the Learys' new revolutionary political stance regarding LSD, Weatherman and the Black Panther party.

C73 “Smoke It/ Smoke It/ Blow It Up.” Berkeley Barb (Nov. 27-Dec. 3):20. Report from Algeria written November 1, 1970, describing and defending the Learys' revolutionary beliefs since spending time with the Weather Underground and the Black Panther party in exile. Published (simultaneously?) in East Village Other (Nov.):3.

C74 “A Letter to Allen Ginsberg." Intrepid, no. 18/19 (Winter):69. Cowritten with Rosemary Leary. Dated Algeria, October 10, 1970, describing their enthusiastic reception by Eldridge Cleaver and the Black Panther party.

\section{1}

C75 "Open Letter to Allen Ginsberg on the Seventh Liberation." Berkeley Barb (Jan. 1-7):3. Coauthored with Rosemary Leary. First appearance of this poem describing the authors' political radicalization. Dated 
Algiers, December 30, 1970. Reprinted in Los Angeles Free Press (Jan. 15); Marijuana Review (Jan.-June 1971); and elsewhere.

C76 "Jail Notes." Evergreen Review, no. 86 (Jan.):52-55, 70-72. Reprint of the opening section of Jail Notes (A12), preceded by a portion of Allen Ginsberg's introduction to the same work.

C77 "Comments From Tim Leary on Ken Kesey's Letter." Marijuana Review, 1, no. 6 (Jan.-June):26-27. First separate printing of Leary's response to Ken Kesey's published letter to him (J210), extracted from Rolling Stone (Dec. 2). Kesey's letter and Leary's prison escape letter are reprinted.

C78 Letter from Switzerland. Berkeley Barb (Nov. 19-25):2, 14. Original publication credited to East Village Other. This very long letter (addressed to Jaakov Kohn, editor of EVO) is an analysis of the Learys' first year in exile following his prison escape. It is preceded by editorial comment regarding the breakup of the Learys' marriage.

\section{2}

C79 "Scripts [I-XV]." Renaissance, no. 8, supplement to The Sunday Paper (Feb. 3-9):[2-6]. Coauthored with Brian Barritt. Poetic account of "time-travellers" Nino and Maia Baraka (a.k.a. Timothy and Rosemary Leary) in Algeria, particularly their captivity by the Black Panther party and their subsequent liberation. A portion of this work originally appeared in different form in Whisper (B24).

\section{3}

C80 "The Principles and Practice of Hedonic Psychology." Psychology Today (Jan.):52-53, 55-58. Text based on the Free University of Berkeley lectures delivered in Mar. 1969, otherwise unpublished.

C81 "Neurologique." Berkeley Barb (May 11-17):6-7.Also: May 18-24; May 25-31; June 1-7. Whole numbers 404-7. Four-part serialization of Neurologic (A13).

C82 Letter to the Editor. Psychology Today (June):4,6. Response to article by Charles Slack (J287).

C83 Letter to Forum members. Forum for Contemporary History (July 2):[1-4]. The entire contents of the issue is devoted to Leary's four-page letter, written from Folsom Prison, Represa, Calif., dated July 2, 1973. The letter deals with the "cultural message of the 1960s." Editorial comments appear on a separate printed sheet into which the 
sheets containing Leary's letter are folded. Reprinted in revised format in Humanistic Psychology Newsletter (C98).

C83a "Sheeeeee. She is Highest Intelligence." Los Angeles Star (Aug. 3):17. Short poetic invocation of cosmic female energy form.

C84 "Starseed: Transmitted From Folsom Prison." The Weekly News (Sept. 28-Oct. 5):16-17. Entire text of this essay, published about the same time as the booklet (A15).

C85 “Terra II." The Real Paper (Nov. 21):8-10. Prepublication of excerpts from the book (A16).

C86 "Leary Statement." Changes (Dec./Jan.):12. On the reasons for the political suppression of drugs and drug research.

C87 "The Day I Was Busted By G. Gordon Liddy." Ramparts (Dec.):45-47. Variant, prepublication version of chapters 2-5 of The Curse of the Oval Room (A17). Illustrated by Gary Hallgren. See J342 for Liddy's account of the same event.

C88 Letter to the Editor. Spit in the Ocean, no. 1 (Dec.). Invites readers of the Ken Kesey/Ken Babbs Oregon-based magazine to contribute theories about "higher intelligence." Results were published in 1977. See C106-9.

\section{4}

C89 "Neurologic." Rallying Point, no. 1 (Jan.):35-50. Reprints the complete text of Neurologic (A13), with Afterword by the publisher, Joanna Harcourt-Smith Leary.

C90 “Terra II." High Times, no.1 (Oct.):23-25. A reworking of the text of Terra II (A16), amounting to an abridgment of the work. Illustration by Yossarian.

C91 Letter to the Editor. New York Times Book Review (Nov.):5. A defense of the late rock singer Janis Joplin, who had been savaged in Midge Decter's review of a Joplin biography.

\section{5}

C92 “The Periodic Table of Energy." Berkeley Barb (Mar. 14-20):10-11. Coauthored with Robert Anton Wilson. An early version of Exo-Psychology (A19): a description of the evolution of the human nervous system in eight "circuits" and twenty-four "slots" or stages. 
C93 "Timothy Leary-Reflections on Society." Parts I and II. San Francisco Examiner (Apr. 8):31; (Apr. 9):37. Critique of lawyers and courts presented in a self-interview.

C94 Letter to the Editor. Newsweek (Apr. 28):5. Writing from prison, Leary attempts to clear up misinformation in a Newsweek report on him published Mar. 10.

C95 "Tim Leary Drops a Line." City of San Francisco (July 6):50. Account of his experiences with Cleaver in Algeria in 1970-71, written "from somewhere in federal custody."

\section{6}

C96 Letter to William Buckley. National Review (Apr. 16):379-80. Letter accompanying the submission of his manuscript published in the same issue (see C97).

C97 "TV and the Outlaw Industry: How Our Paranoias Are Hyped For Fame and Profit." National Review (Apr. 16):382-85, 389-90, 410. About political outlaws, left-wing lawyers and exploitive rock singers. This is an earlier, variant version of Chapter 2 of Neuropolitics (A20).

C98 "Seeds of the Sixties." Humanistic Psychology Newsletter (Apr.). Revised text of the "Forum Letter" (C83) with new title.

C99 "Brainwashing: How To Fold, Spindle, and Mutilate the Human Mind in Five Easy Steps." Oui (June):42-46,93-96. Coauthored with Robert Anton Wilson. Prepublication of Chapter 13 of Neuropolitics (A20).

C100 "Meeting Manson." Oui (Aug.):46-48, 97-102. Prepublication of Chapter 14 of Neuropolitics (A20).

C101 "Tim Leary on Snake Oil, Liberals, Amino-Uganda." L-5 NEWS (Aug.):4-5. Prepublication of Chapter 21 of Neuropolitics (A20).

C101a“From Inner Space to Outer Space." Laughing Coyote. Prepublication of chapter 16 of Neuropolitics (A20).

C102 "Some Personal Observations on the Emergence of Third and Fourth Brain Imprints in Adolescent Males." Outpost 1, no. 1 (Winter 1976/77):15-20, 46-50. Reminiscences of his high school, college and military academy years. See C104 for sequel. 
C103 "Neuro-Astrology." Gnostica, no. 42 (Apr./May):13-19. Coauthored with Robert Anton Wilson. The twelve astrological signs are presented as evolutionary stages: "Zodiac I" and "Zodiac II."

C104 "In and Out of Time." Outpost 1, no. 2-3 (Spring-Summer):30-33, 69-77. Continuation of C102. A further installment was promised but did not appear.

C105 "A Cosmic Wink of the Third Eye. Tim Leary on Wisdom and Wilson." Berkeley Barb (Oct. 21-27):8-9. Prepublication of his introduction to Robert Anton Wilson's Cosmic Trigger (B33).

C106 "Preface." Spit In the Ocean, no. 3 (Fall):8-11. Guest editor Leary explains that "this issue is devoted to the transmissions of exo-psychologists and psychophysicists."

C107 "Exo-Psychology." Spit In the Ocean, no. 3 (Fall):15-22. Prepublication of Chapter 1 of Exo-Psychology (A19), varying slightly from the book version.

C108 "Communication with the Higher Intelligence. A Review of Albert Bester." Spit In The Ocean, no. 3 (Fall):66-75. On Bester's The Stars My Destination, "one of the best Science Fiction novels ever written."

C109 "Kekule's Dream Serpent Makes a Good Logo. A Review of Thomas Pyncheon." Spit In the Ocean, no. 3 (Fall):94-98. Long quotation from Gravity's Rainbow with parenthetical remarks by Leary.

C110 "The Sexual Revolution 1977-2001." Parts I-IV. L.A. Star, nos. 143-46. Coauthored with Robert A. Wilson. Prepublication of Chapter 17 of Neuropolitics (A20), varying somewhat from the book version.

C110aArticle on Bob Dylan. Rocky Mountain Musical Express (Nov.). See J396. Not seen.

\section{9}

C111 “Increasing Intelligence." Humanistic Psychology Newsletter (May):6.

C112 Column. Topanga Messenger (July 5):6. On the "cold war between the socialist states of East America and Western America."

\section{0}

C113 Letter to the Editor. Co-Evolution Quarterly, no. 25 (Spring):142. In praise of the magazine; critical of cartoonist $R$. Crumb. 
C113a"Neuropolitics: The Meaning of Space Migration." City Miner, no. 12 (prior to May):26-28, 30. First appearance of speech delivered Oct. 1977 and printed in Worlds Beyond (B34).

C114 "And the Twain Shall Never Meet." L.A. Weekly (July 25-31). On the different cultures of the eastern and western United States, written under the pseudonym Barbara Chase.

C115 "Self-Indulgence, Survival, and Space." Futurist (Oct.):10-11.

C116 Letter to the Editor. Horace Mann Monitor (Dec.). Protesting traffic-offense policies of the local school PTA. Written under the pseudonym Barbara Chase.

C117 "How to Surf the Crime Wave." Los Angeles Weekly (?), late 1980. On the manner in which the rnedia "creates crime waves."

\section{1}

C118 Letter to the Editor. Los Angeles Times Calendar (Jan. 4). On the hiring and firing of Leary as a radio commentator by station KEZY, written under the pseudonym Irving Blum.

C119 Letter to the Editor. Los Angeles Herald Examiner (Jan.). Protesting "literary dingbats" such as Norman Mailer who profitably exploit murderers. Written under the pseudonym Barbara Chase.

C120 "Scientist Superstars." Future Life, no. 24 (Feb.):70, 72-73. "Science and only science can solve the problems of the past and fabricate the improved future."

C121 Letter to the Editor. Los Angeles Herald Examiner (Mar. 21). Protesting actress Carol Burnett's suit against the National Enquirer. Written under the pseudonym Barbara Chase.

C122 Letter to the Editor. Los Angeles Herald Examiner (Mar. 28). Protesting American partisan politics. Written under the pseudonym Henry Edwards.

C123 "Ode to a Pyramid." Los Angeles Times (Mar.?). About the pyramid movement, "one of the finest flowerings of capitalism."

C124 Letter to the Editor. Los Angeles Times (Mar.?). Protesting the punishment of Ian Kennedy, DNA researcher, by the NIMH.

C125 Letter to the Editor. Los Angeles Times (July?). Protesting police radar surveillance on highways. Written under the pseudonym Barbara Chase. 
C126 "Higher Consciousness and Creativity." High Times, no. 76 (Dec.):36-38. Leary's opening talk to a colloquium, "Higher Intelligence," with further remarks after other speakers.

C127 "The Spooked Trickster, The Whimsical Scientist, and the Flunked Anthropologist." [publication and date unknown.] Review of Carlos Castenada's The Eagle's Gift and Richard DeMille's The Don Juan Papers.

\section{2}

C128 "The Future of Sex." Puritan, no. 8 (1982):18-20, 74, 92. Advises readers to "write your own script . . . . Variety is the key."

\section{3}

C129 Letter to the Editor. Los Angeles Herald Examiner (Mar. 8). Response to a reader's negative reaction to the psychotherapy profession based on the film Lovesick.

C130 Letter to the Editor. Los Angeles Times (Mar.). In praise of the recently deceased writer Arthur Koestler, the circumstances of whose death left us with much to think about.

C131 Letter to the Editor. Los Angles Herald Examiner (Mar.). Protesting columnist William Buckley's anger over the treatment of Jeane Kirkpatrick on college campuses. Written under the pseudonym Barbara Chase.

C132 “Tim Leary's Magic Bullet." Psychology Today (July):30-38. Excerpts from Flashbacks (A25) in somewhat revised form.

C133 "The Murder of Mary Pinchot Meyer." The Rebel, no. 1 (Nov. 22):44-49. An investigative report on a close associate of President Kennedy known to the author in the early ' 60 s.

\section{4}

C134 “My Debt to Deborah Davis.” The Rebel (Jan. 23):72-74. Continuation of $\mathrm{C} 133$.

C135 "Faces." The Rebel (Jan. 30):58-59. Gossip column anonymously written by Timothy and Barbara Leary. 
C136 "Faces." The Rebel (Feb. 20):72-73. Gossip column anonymously written with Barbara Leary.

C137 "Faces." The Rebel (Feb. 27):74-75. Gossip column anonymously written with Barbara Leary.

C138 “America's Team." Los Angeles Free Press (Feb.). On the psychological and sociological meaning of the most recent Super Bowl game.

C139 "No Golden Anniversary for this Ex-Dodger Fan." Los Angeles Free Press (Mar.). How team policies and style have made the writer an ex-Dodger fan.

C140 Letter to the Editor. Los Angeles Times Calendar (Mar.). How the "link up between personal brains and personal computers will preserve and nurture human individuality and freedom."

C141 "The Joys of Pornography." Hustler (Mar.):58-60, 58-60, 72, 74. Reflections on the history and psychology of erotic and pornographic literature.

C142 "Even to Envision Success on this Scale is a Victory." Los Angeles Weekly (June). Review of William Burroughs's novel The Place of Dead Roads.

C143 "Perfect Worlds." Harpers (July):4. Letter presenting author's vision of paradise.

C144 "We've Lost the War; Legalize All the Drugs." USA Today (Nov. 28):10A. The "war on drugs" as a "generational conflict."

\section{5}

C145 “The Persecution of Larry Flynt." Hustler (Jan.):82-83. Flynt is placed in the tradition of American rebels from Huck Finn to Lenny Bruce.

C146 "How I'd Make L.A. a Better Place." Los Angeles (Jan.):132. Predicts Los Angeles will secede from the United States and become known as Pacifica.

C147 "Electronic Sex: Turning On to Your Computer." Hustler (Feb.):82-84, 86, 96, 98, 108. On sexual interactions made possible by computer interfacing.

C148 "Timothy Leary's Melrose Avenue for William Burroughs." California Magazine (June):116-18, 154-55, 163. Leary describes Los Angeles's Melrose Avenue district for novelist and friend Burroughs. 
C149 "XTC: The Drug of the '80s." Chic (July):75-76. Author recounts his positive experiences with the drug MDMA.

C150 "Onward Christian Soldiers: A Brief History of the Warrior Caste in America." Hustler (Oct.):50, 52, 93-94, 96, 98. A critique of the history and politics of American military adventurism. Reprinted in Best of Hustler, vol. 12 (1986).

C151 "In Search of the True Aphrodisiac." Chic (Nov.):18-20, 22, 30, 32, 84. Describes the effects of substances from mandrake root to yohimbine to LSD, and concludes that "the most powerful sexual organ in the universe [is] the brain."

C152 Letter to the Editor. Psychedelic Monographs and Essays I, no. 1 (Autumn):[72-73]. "Highly Interactive Software is the means through which the acid-activated mind can communicate. I am writing a book about this."

\section{6}

C153 "The Unreported Rape of Irving Katz." Hustler (Aug.): 36-38, 48, 50, 88. Satirical short story about an incident of sexual assault.

C154 "The Role of the Free Agent in the Computer Culture." The Guide to Computer Living (Oct.): 41-43. "Those who like to think for themselves tend to see computers as thought appliances."

C155 "Operation Sex Change." Hustler (Oct.): 36, 38, 100, 102, 104. Despite appearances, there is not a new sexual conservatism today, people are just more selective.

C156 "Quantum Jumps, Your Commodore and You." The Guide to Computer Living (Nov.): 53-56. Why "electronic reality is more real than the physical world."

C157 “The Big Boom Theory." Regardie's (Nov.): 154-57. On the influence of Dr. Benjamin Spock on the "baby boom" generation.

C158 "Artificial Intelligence: Hesse's Prophetic 'Glass Bead Game'." Mosaic (Fall): 195-207. Novelist Herman Hesse as "prophet of the computer culture" as well as the previous drug culture.

C159 "The Erotic Brain." Puritan, no 11: 44-45. How the brain imprints sexual experience for use at a later time. 


\section{D. \\ Interviews}

\section{6}

D1 "Playboy Interview: Timothy Leary." Playboy (Sept.):93-112, 250-51, 254-56. One of Leary's most controversial interviews, focusing in part on the sexual aspects of LSD. See AA47 and B15 for offprint and book publication.

D2 “An Impolite Interview with Timothy Leary." The Realist, no. 69 (Sept.):1, 6-12, 14-15. A freewheeling interview with Realist editor Paul Krassner, later reprinted in Politics of Ecstasy (A8) as "A Trip with Paul Krassner." Excerpt reprinted in: The Best of the Realist, ed. P. Krassner. Philadelphia: Running Press, 1984, pp. 144-45.

D3 "God and Timothy Leary." Ave Maria, no. 25 (Dec. 17):7-10. Interviewed by Joe O'Sullivan on the religious aspects of LSD.

D4 “An Interview-Timothy Leary, LSD, and Religion." Innisfree, no. 2 (Dec.):14-23, 26-27. Interviewed by college students Jim Smith and Cynthia White.

D5 ["Interview with Timothy Leary"]. Sunday Ramparts (1966). Interview with Jann Wenner that was censored and then restored. Not seen.

\section{7}

D6 "Psychedelic Utopia." U. of Washington Daily (Feb. 9).

D7 “Another Session with Timothy Leary." City of San Francisco Oracle, no. 10 (Oct.):5, 12, 24-26. Interview conducted by the staff of the Oracle. Reprinted in Orpheus, no. 3 (1967). 
D8 “Tim Leary's Prediction." Southern California Oracle, no. 2 (Oct.):3-5, 24. Interview conducted by Joe Dana at Millbrook. Reprinted in Human Alternatives (B25.1).

D9 “An Interview with Dr. Timothy Leary." Heads Up, no. 2 (Fall):11-14. Discussion of tribal life at the Millbrook commune.

D10 "SOL Session with Timothy Leary." SOL:64-76. Interview conducted at Millbrook with members of the magazine of San Fernando Valley State College, Calif. (interview with Ronald Reagan in same issue). Reprinted in Politics of Ecstasy (A8) as "Soul Session."

\section{8}

$D 11$ “Acid Return." Good Times (July 3):5-7. Interviewed by Scoop Nisker on the subject of LSD and politics.

D12 "Laughing Leary." East Village Other (Oct. 25). Interviewed by Jakov Kohn about his recent books, legal problems and communes. Reprinted in Our Time (B26).

D13 “The Oracle Interviews Timothy Leary." San Francisco Oracle (2nd series):11, 21-22. Interviewed by Mansur on astrology, LSD and tribal communes.

\section{9}

D14 "The God Game: How to Win." Berkeley Barb (Feb. 14-21):16-17. Interview conducted by Phineas Israeli at Leary's Berkeley home on the impact of LSD on different levels of society.

D15 "Come Together, Join the Party." East Village Other (June 4):3, 19-20, 23-24. Interview conducted by Jaakov Kohn on Leary's decision to run for governor of Calif. in 1970. Reprinted in Our Time (B26).

D16 "Leary Love Rap." Berkeley Barb (Dec. 26-Jan. 2):3, 19. Interviewed by "Lois Lane." Discussions of Chicago Seven Trial, Woodstock and Altamont concerts.

\section{0}

D17 "Does Timothy Leary Eat Mushroom Pie? A Screw Interview." Screw (Jan. 19):12-13. Interviewed by Al Goldstein on LSD and sexuality, and his ideas on governing Calif. 
D18 "We Were Freed by a Great Network of Love." Los Angeles Free Press (Oct. 23-29): 1-2. Interview from Algiers conducted by Elliot Mintz on Leary's prison escape and flight to North Africa.

D19 "Tim Leary: Or, Bombs for Buddha." Rolling Stone (Dec. 2):20. Interview from Algeria conducted by Bob Greenfield. Leary reveals his new political philosophy.

\section{1}

D20 "Hedonic Isolationism." East Village Other (Jan. 12). Interviewed by Jaakov Kohn and Alex Bennett by phone from Algeria. Reprinted in Our Time (B26).

D20a "Timothy Leary: This Fine Madman." Crawdaddy (Aug. 1). Interviewed by Paul Williams. Not seen.

D21 "We're Together and We've Probably Never Been Happier." Los Angeles Free Press (Sept. 3-9):2-3. Telephone interview from Switzerland, where the Learys went after things got hot for them in Algeria.

\section{2}

D22 "Dr. Timothy Leary: Blowing the Conditioned Mind." Los Angeles Free Press, Part II (Aug. 18-28):1, 4-5. Interviewed by Kenneth Kahn in Switzerland on the nature of life in exile.

\section{3}

D23 "Tim Leary: A Letter and an Interview from Prison." Los Angeles Free Press (Mar. 2):3-4. An interview in prison by Elliot Mintz. This is Leary's first public interview after his capture in Afghanistan. Letter is to Joanna Harcourt-Smith.

D24 “Tim Leary: Interview." Los Angeles Star (Aug. 3):10-11, 17. Interviewed by Dennis Martino in Switzerland, Dec. 1972, one month before capture.

D25 "They Took Away My Credit Card." $O z$ (Nov.):43-46. Exclusive interview from prison with this London-based underground magazine.

D26 "The Rolling Stone Interview with Timothy Leary." Williams, Paul. Pushing Upward. (New York: Links), pp. 129-48. Interview by Paul 
Williams, recorded at Leary's Berkeley home in Feb. 1969. Despite title, there is no record of this interview appearing in Rolling Stone.

\section{4}

D27 “A Phone Call from Jail." Soho Weekly News (Mar. 6):4, 8. Interview by Jaakov Kohn while Leary was in federal custody.

\section{6}

D28 "Leary Trades Drugs for Space Colonies." Berkeley Barb (June 11-17):6-7. Interviewed by his current literary collaborator Robert Anton Wilson, following his release from prison.

D29 "Interview with Dr. Timothy Leary." Maclean's (Nov. 15):4, 8-9. Interviewed by Richard Louv and Carole Snyder. Louv and Snyder report in the Canadian weekly that Leary is no longer interested in drugs and "his newest cause is interplanetary travel and colonization."

D30 "Innerview." Head, no.8 (Nov./Dec.):33-35, 55, 61. Interviewed by Allan Earle, Leary talks mainly about his new acronym SMI ${ }^{2}$ LE (Space Migration, Intelligence Squared, Life Extension).

D31 "Movement into Space: A View from Two Worlds." $L-5$ NEWS, no. 16 (Dec.):6-7, 10-11. Tucson, Ariz. Part one of interviews with Leary and Captain Robert Freitag. See D33.

\section{7}

D32 "Timothy Leary: Messenger of Evolution." Los Angeles Times (Jan. 30):1, 15-17. Subtitled, “'Game Between Robots': An Insight into the Future." Leary presents his ideas about the future. Followed by article by William Overend about Leary, "New Trip is Exodus into Outer Space."

D33 "Movement into Space: A View from Two Worlds." L-5 News, no. 1 (Jan.):3-7. Part two of interviews with Leary and Captain Robert Freitag.

D34 "Interview with Timothy Leary." Los Angeles Star (1977):10-11, 36. On the '60s, Eldridge Cleaver, and the necessity for space migration. 


\section{8}

D35 "Interview: Dr. Timothy Leary: The Evolutionary Surfer." Surfer, no. 5 (Jan.):100-103. Interviewed by Steve Pezman. "On any planet like ours, when a culture gets into surfing, it's a sign of maturity on the part of that species!"

D36 "Timothy Leary on Acid and the CIA." High Times, no. 30 (Feb.):46. Leary credits the CIA with sponsoring the LSD movement.

D37 “Timothy Leary's New Trip: A Reason Interview." Reason (Apr.):30-34. Leary puts his ideas in a Libertarian perspective. Interview conducted by Jeff Riggenbach.

D38 “Timothy Leary: Still (SMILE)*ing After All These Years?" The Advocate (Aug. 23):14-20. Discussion of homosexuality, society and evolution. Conducted by Dean Gengle.

D39 "Timothy Leary." Wet, no. 15 (Nov./Dec.):22-24. Interviewed on the subject of personal style ("the most important thing in human evolution right now") and fashion.

\section{9}

D40 "3 Billion Years from Amoebas to Howard Cosell." Berkeley Barb (Jan. 18-31):8. Interviewed by Spencer Rumsey on the occasion of Leary's first San Francisco lecture in ten years.

D41 "Interview." Future Life, no. 10 (May):32-34, 66. Interviewed by Robin Snelson on the meaning of the slogan $\mathrm{SMI}^{2} \mathrm{LE}$.

D42 “The Once and Future Timothy Leary." Hi Life, no. 5 (May):36-39. Interview with former colleague Michael Hollingshead.

D43 "Timothy Leary: Space Cadet." Chic, no. 9 (July):86. Interviewed by Jeff Goldberg on "1990s concepts."

\section{1}

D44 "Timothy Leary." Slick, no. 3 (1981). Rick Hermann interviewed Leary after his performance in a San Francisco nightclub. 
D45 "Drug Cult Guru Still Heading for Outer Space." Ann Arbor News (Nov. 2):A9. Leary compares and differentiates himself from G. Gordon Liddy, with whom he has been debating, in this interview with Jeff Mortimer.

\section{3}

D46 "Timothy Leary: The Doctor Is In." Mix, no. 7 (July):62-65. Interviewed by Bonzai, Leary talks about the influence of popular music on his life.

D47 “Turn-on, Tune-in, Take Charge?" New Frontier (July-Aug.): 11-12, 18,22 . Interviewed by Philip S. Lansky on imprinting, genetic typology and computers.

D48 "Cheerleader for Change: The Timothy Leary Interview." Heavy Metal (Oct.):42-46. Interviewed by Michael Simmons on material published in Flashbacks and his recent activities.

D49 “Tim Leary." In Magazine, no. O (1983):8-9. Interviewed by "Anon" from video transcript, on a wide range of topics, from space migration to fashion.

\section{4}

D50 "Q \& A: Timothy Leary: The Case for Intelligent Drug Use." Maclean's (Mar. 5):8-9. Interviewed by Michael J. McRae. About today's new drugs ("Ecstasy," etc.) compared to those available in the '60s. He is " $100 \%$ in favor of the intelligent use of drugs and $1,000 \%$ against the thoughtless use of them."

D51 “Q \& A: Timothy Leary." InfoWorld (July 23):46. Interviewed by Denise Caruso on his creation of a new programming language called SKIPI (Super Knowledge Information Processing Intelligence).

D52 “On Mind as Aphrodisiac: Interview with Timothy Leary." Puritan, no. 10 (Nov.):34-37, 106-109. On the erotic power of brain circuits. Interview conducted by Jeffrey Michelson and Sarah Stone. Reprinted in The Best of Puritan, Vol. 2 (1986).

D53 “Access Codes and Carnival Blasts." High Frontiers, no. 1:4, 23-26. Transcript of interview conducted by Will Noffke of KPFA, Berkeley, July 1983. 


\section{5}

D54 "How I'd Make L.A. a Better Place." Los Angeles (Jan.):132. In an interview with Jim Seale, Leary suggests that "by 1990 Los Angeles will have seceded from the American empire."

\section{6}

D55 “Dr. Timothy Leary." "On Drugs: Dr. Leary." Splash (Spring): 53-57; 56-57, 84, 86. Two free-wheeling, interactive interviews, the first by Mary Akashah, Lynn Logsdon and Christopher Browne. In the second, Leary explains to Rick Doblin why he would rather discuss computers than drugs.

D56 "Dr Timothy Leary on: The Evolution of Computer Literacy." Whole Life Monthly (Sept.): 5-8. Interviewed by Charles Hyatt on his computer software program Mind Mirror.

D57 "LSD: Leary Software Development." New Frontier (Sept.):19-21, 49. Interviewed by Djuna Wojton on Mind Mirror and the comparative values of psychedelic drugs and computers.

D58 "Timothy Leary Inside Out." Magical Blend, no. 13 (prior to Oct.):35-42. Leary talks about computers, his interest in designing "Highly Interactive Software," and the slogan that exemplifies the meaning of life and work: Think For Yourself, Question Authority. Interview conducted by Christopher Miles. Excerpted in L.A. Weekly, (Oct. 17-23).

D59 "Dr. Timothy Leary, from the Psychedelic Sixties to the Electronic Eighties." The Guide to Computer Living (Dec.): 6-16. Lengthy interview by Randy Chase on the relationship between '60s drug research and ' 80 s computer software, and the next Leary project, "mind movies." 


\section{E. \\ Translations of Books and Articles}

\section{ARABIC}

E1 Neurocomic. Cairo (?), 1983. 32 pp. Wrappers. Translation of Neurocomics (A22). This is apparently the first work of Leary's to be translated into Arabic.

\section{BINARY}

E2 Prologue to Terra II: The Starseed Transmission (A16), p. [5], translated into binary code and printed by micro-lithographic process on a silicon disk in a hexagonal pattern. Diameter: $7 / 8$ in.; thickness: $1 / 8$ in. "Silicon Valley," Calif., Dec., 1973. Conceived by Leary and L. Wayne Benner, principal authors of Terra II, in Folsom Prison, Calif., as a promotional idea to call attention to the publication of the book in Jan. 1974, to the imperative of leaving the planet in spaceships to search for Higher Intelligence, and to their plight as prisoners. The project was executed by Joanna Harcourt-Smith Leary and a number of aides. The cover of Terra II is an enlarged photoreproduction of the image on the disk. About thirty-five disks were produced; many were found imperfect. The best examples were scattered around the United States and Europe to be found later as "messages from Higher Intelligence."

\section{DUTCH}

E3 "De Religieuze Ervaring/ Hoe deze Wordt Opgeroepen en Geinterpreteerd." Maatstaf, no. 10/11 (Jan.-Feb. 1967):779-811. The Hague, Netherlands. Translation by Simon Vinkenoog of "The Religious Experience: Its Production and Interpretation" (AA43).

E4 Timothy Leary Magier. Het ABZ van de Psychedelische Avant-garde. By Simon Vinkenoog. Netherlands: A. W. Sijhoff's Uitgeversmaats- 
chappij N.V., 1972, various pp. Contains the following translations by Simon Vinkenoog): "God's Geheim Agent A.O.S.3," pp. 112-24 (C53); "Je bent een God, handels als een God," pp. 168-71 (C50) ; "Het experiment," p. 176 (excerpt from A7); "Lachende Leary" (interview with Jaakov Kohn), pp. 177-81 (D12); "Deal for Real," pp. 182-87 (C61); "Joujouka," pp. 188-207 (excerpt from A12); "Timothy Leary over Franz Gertsch," pp. 212-14 (B27).

\section{FRENCH}

E5 "Une Interview du Grand Pretre du LSD: Timothy Leary." Crapouillot, no. 71 (1966):36-39, 50-59. Translation of Leary's Playboy interview (AA47), with rare photo of Leary with group in Zihuatenejo.

E6 "Sur la Programmations des Experiences Psychedeliques." Mandala. Essai sur l'experience hallucinogene, ed. J.-C. Bailly and J.-P. Guimard. Paris: Editions Pierre Belfond, 1969, pp. 269-84. Translation by A. Illion of "On Programming Psychedelic Experiences" (C51), by Leary and Ralph Metzner.

E7 Politique de l'Extase. Paris: Fayard, 1973.451 pp. Wrappers. Translation by Pierre Sisley of The Politics of Ecstasy (A8).

E8 Neurologique. Mainmise, nos. 28-29 (Oct. \& Nov. 1973):57-72; 2840. Translation by Michel Chevrier of Neurologic (A13), complete in two issues. Illustrated. Printed in Quebec.

E9 Graine d'Astre. Mainmise, no. 30 (Dec. 1973):20-25. Translation (by M. Chevrier?) of Starseed (A15). Illustrated. Printed in Quebec.

E10 Terra II. Transmission de Graine d'Astre. Mainmise, no. 39 (Sept. 1974):14-63. Translation of Terra II (A16). Illustrated.

E11 Exo-Psychologie. Le Systeme nerveux humain: mode d'emploi (conforme aux instructions de ses createurs). (At head of title: La Revolution Cosmique.) Paris: Presses de la Renaissance, 1979. 256 pp. Wrappers. Translation by Denis Authier of Exo-Psychology (A19).

E12 Memoires Acides. Paris: Editions Robert Laffont, 1984. Wrappers. Translation by Emanuel Jouanne of Flashbacks (A25).

\section{GERMAN}

E13 "Ein unhofliches Interview mit Timothy Leary." Reavis, Edward. Rauschgiftesser erzahlen. Eine Dokumentation. Frankfurt am Main: Barmeier \& Nikel, 1967, 281-306. Translation by Meinhardt Buning 
of Paul Krassner's "Impolite Interview with Timothy Leary" (D2). Printed in Romania.

E14 "Changes." Hotcha, nos. 33, 36 (Oct./Nov. 1969). Translation of "Changes" (C46). Printed in Zurich.

E15 Politik der Ekstase. Hamburg: Christian Wegner, 1970. 223 pp. Wrappers. Partial translation by Irmela Brender of Politics of Ecstasy (A8). Introduction by Ronald Steckel. A photo-offset reprint was published in Amsterdam/ Kathmandu: God's Press, 1976. See E30.

E16 "Laughing Leary." UFO, no. 2 (Oct. 1971):30-32. Translation (by Carl Weissner?) of a text by Leary and Brian Barritt. Printed in Frankfurt.

E17 Psychedelische Erfahrungen. Ein Handbuch nach Weisungen des Tibetansichen Totenbuches. Weilheim/Oberbayern: Otto Wilhelm Barth, 1971. $136 \mathrm{pp}$. Wrappers. Translation by Ursula von Mangoldt of The Psychedelic Experience (A4), with a preface by the translator. A photo-offset reprint with translator's preface deleted was published in Amsterdam/ Kathmandu: God's Press, 1975. 2nd ed. (also deleting translator's preface): Linden, W. Germany: Volksverlag, 1981. 121 pp. Wrappers.

E18 "Interview mit T. Leary." In the Swiss High-Lands, no. 1 (Feb. 1972):3-8. Interview conducted by Swiss writer Sergius Golowin. Illustrated with facsimile manuscript. Printed in Gurtendorf.

E18a Kosmologie der Freude. By Alan W. Watts. Darmstadt: Melzer Verlag [1972]. 112 pp. Wrappers. German translation by Ted Weissenborn of The Joyous Cosmology (B3), with a foreword by Leary and Richard Alpert.

E19 "Freedom for Timothy Leary." Panderma, no. 12 (Summer 1974). 20 pp. Special number entirely devoted to Leary, edited by Carl Laszlo. Contains reprints of "The Politics of Consciousness Expansion" (AA42), "You Are a God, Act Like One" (C50), portions of The Psychedelic Experience (A4), and Starseed (A15). (The latter is in English; the others are in German translation.) Printed in Basel.

E20 Gebete. Psychedelische Gebete nach dem Tao-Te-King. Bern: Mantram, 1975. $176 \mathrm{pp}$. Boards, dust jacket (designed by H. R. Giger). Bilingual edition, with German translation by Michael A. Binder of Psychedelic Prayers after the Tao-Te-Ching (A5). With Forewords by Brian Barritt and the translator, and Afterword by Sergius Golowin. Photo-offset reprint: Amsterdam/ Kathmandu: God's Press, 1975. Reprint of the German text only: Linden, W. Ger.: Volksverlag, 1982. 108 pp. Wrappers. 
E21 Neurologik. Linden, W. Ger.: Volksverlag, 1977. 30 pp. Wrappers. Translation by Dr. Dietmar Hohne of Neurologic (A13). Photo-offset reprint: Amsterdam/ Kathmandu: God's Press, 1977(?). (2nd ed.: Linden: Volksverlag, 1982. 61 pp. Wrappers.) (Note: the earliest translation of Neurologic was made by Noly Stanschus in 1975 while in solitary confinement in a German prison and was distributed in a very small xerographic edition.)

E22 Terra II (Die Kolonialisierung des Weltraums). Sphinx, no. 3 (Oct. 1978):10-12. Translation by Udo Breger of a portion of Terra II (A16). Printed in Basel.

E23 “Giger-Ein Visionarer Kunstler.” Sphinx, no. 6 (Sept. 1979):14-15. Excerpt from Leary's foreword to Giger's Alien (B35), translated by Dieter A. Hagenbach. Printed in Basel.

E24 “Interview mit Timothy Leary." Sphinx, no. 6 (Sept. 1979):20-29. Translation by Dieter A. Hagenbach of interview conducted by Dean Gengle (D38).

E25 Was Will die Frau? Basel: Sphinx Verlag, 1980. 318 pp. Wrappers. Translation by Pierre Hanni of What Does WoMan Want? (A18).

E26 "Wissenschaftler-Superstars." Sphinx, no. 14 (Autumn 1981):34-38. Translation by Dieter A. Hagenbach of "Scientific Superstars," the epilogue to Changing My Mind, Among Others (A24), and in: Millenium (B37).

E27 Exo-Psychologie. Basel: Sphinx Verlag, 1981. 165 pp. Wrappers. Translation by Rene Taschner of Exo-Psychology (A19).

E28 Neuropolitik. Mit Robert Anton Wilson und George A. Koopman. Basel: Sphinx Verlag, 1981. 163 pp. Wrappers. Translation by Gregor Pott of Neuropolitics (A20).

E29 Neurocomic. Basel: Sphinx Verlag, 1981. 32 pp. Wrappers (after the American edition). Translation by Gregor Pott of Neurocomics (A22).

E30 Politik der Extase. Linden, W. Ger.: Volksverlag, 1981. 354 pp. Wrappers. First translation of complete text of The Politics of Ecstasy (A8) into German. Translated by Irmele Brender and Werner Pieper.

E31 Die Intelligenz Agenten. Basel: Sphinx Verlag, 1983. Translation by Gregor Pott of The Intelligence Agents (A21).

E32 "Neue Kathedralen im Weltraum." Esotera (1983). Freiburg, W. Ger. Interview conducted by Sybille Grelling.

E33 Spiel des Lebens: Neurologisches Tarot. Basel: Sphinx Verlag, 1984. 200 pp. Wrappers. Translation by Susanne G. Seiler of The Game of Life (A23). 
E34 "Hochst-Interaktiv Software." Sphinx, no. 28 (Oct./ Nov. 1984):16-17. At end: "Timothy Leary fur SPHINX/ 5. April 1984, Los Angeles." Apparently, the first printing of this text in any language. Preceded by discussion between Leary and his translator (Susanne G. Seiler) on the subject of his computer program SKIPI (Super Knowledge Information Processing Intelligence).

E35 "Meine Suche nach dem Wahren Aprodisiakum." Sphinx, no. 35 (Dec. 1985/Jan. 1986):14-18. Translation by Peter Maybach of "In Search of the True Aphrodisiac" (C151).

E36 Denn Sie Wussten Was Sie Tun: Eine Ruckblende. Basel: Sphinx Verlag, 1986. 446 pp. Boards, dust jacket. Translation by Susanne G. Seiler of Flashbacks (A25).

E37 "Hermann Hesse, ein Prophet des Informations-zeitalters." Sphinx, no. 37 (Sept. 1986): 16-21. Translation of "Artificial Intelligence: Hesse's Prophetic 'Glass Bead Game'” (C158).

\section{ITALIAN}

E38 “Una Carta degli Hippies." Che fare, no. 2 (Nov. 1967):13-18. Translation by Miriam Sumbulovich of a portion of the four-way interview that included Leary that appeared in the City of San Francisco Oracle (C46). Printed in Milan.

E39 L'Esperienza Psichedelica. Milan: Sugar Editore, 1969. 187 pp. Wrappers. Translation by Ugo Carrega of The Psychedelic Experience (A4).

E40 La Fuga.[Italy]: Arcana Editrice (1974?). Translation of Confessions of a Hope Fiend (A14). Not seen. Noted in E41, p. 46.

E41 Timothy Leary il Profeta. Libelli di Fallo!, no. 3 (1974?). 88 pp. Wrappers. Distributed by Edizioni Savelli. Illustrated account of Leary's life and work by Angelo Quattrocchi, containing partial translations of two interviews and one poem from Psychedelic Prayers (A5).

\section{JAPANESE}

E42 Namaenonai Shinbun. Tokyo: Free Press of Kichijoji, nos. 62, 64-67/68 (Mar.-May 1974). Translation by Tashi Toshi of Starseed (A15), illustrated by Norio Ochiai. Printed in Tokyo. 


\section{SPANISH}

E43 Confesiones de un Adicto a la Esperanza. Barcelona: Producciones Editoriales, 1978. Star Books No. 24. 318 pp. Wrappers. Translation by Eloi Riubugent Alsina of Confessions of a Hope Fiend (A14). 


\section{F. \\ Phonograph Records and Tape Recordings}

F1 Turn On, Tune In, Drop Out. ESP-DISK 1027. New York, 1966. Long-playing record album. Front cover: positive-negative photomontage of author by Walter Bredel printed in black and light blue. Back cover: "Timothy Leary, Ph.D. speaks on L.S.D."; credits and ads for other records. Speaking from his Millbrook, N.Y. estate, Leary relates anecdotes of Mexican experiments, provides data on psychedelic action on the human nervous system and discusses the fears and resistance of most adults to the drug experience.

F2 L.S.D. Pixie Records. Monaural CA 1069. New York [1966]. Long-playing record album. Front cover: psychedelic-style mandala in orange and purple. Back cover: photograph of author in Brooks Brothers suit, biographical note by Carol Arket, list of some questions discussed. Author, speaking again from Millbrook estate, discusses the effects of LSD on the nervous system, the determinants of set and setting and why the drug poses a threat to the establishment.

F3 The Psychedelic Experience. Readings from the book "The Psychedelic Experience: A Manual Based on the Tibetan Book of the Dead". By Timothy Leary, Ph.D., Ralph Metzner, Ph.D. and Richard Alpert, Ph.D. Broadside Records BRX 601. New York, 1966. Long-playing record album. Front cover: large mandalic drawing by Edward Epstein printed in black on pink. Back cover: black and pink, with printed credits. Cover design by Ronald Clyne. Inside jacket is a four-page leaflet of text (AA49), written by Leary and Metzner, to accompany the recording. Side 1: Going Out. Side 2: Coming Back. Re-released by Folkways Records, FL 9701. Like the book of the same name (A4), the record has been continuously in print since the time of its initial release.

F4 L.S.D. A Documentary Report on the Current Psychedelic Drug Controversy! Capitol Records TAO 2574. Hollywood [1966 or 1967]. 
Long-playing record album. Fold-open album cover photo in color and seven black-and-white photographs by Lawrence Schiller of persons under the effects of LSD, taken from the book, $L S D$ by Sidney Cohen and Richard Alpert, 1966 (J81). "Actual recordings of people under the influence of psychedelic drugs. . . . Comments by such LSD authorities as Sidney Cohen, M.D., the controversial Dr. Timothy Leary, Mrs. Aldous Huxley, and Allen Ginsberg"-from the liner notes written by Alan W. Livingston, president of Capitol Records.

F5 Turn On, Tune In, Drop Out. The Original Motion Picture Soundtrack. Mercury Records Stereo SR 61131. Chicago, 1967. Long-playing record album. Front cover: Psychedelic art and lettering in red, blue, green, black and white by John Caba. Back cover: Liner notes within decorative border by same artist. Soundtrack of the film version (see G6) of Leary's "psychedelic celebrations" staged in a number of cities in the preceding year. Timothy Leary plays the role of the Guide, Ralph Metzner is the Voyager, and Rosemary Woodruff is the Divine Connection. Side 1: Turn On, Tune In, Drop Out; "The Trip." Side 2: "The Trip" (continued).

F6 Changes. Conversation among Leary, Allen Ginsberg, Alan Watts, Gary Snyder and Allen Cohen. Broadcast on KPFA Pacifica Radio, Berkeley, Feb. 1967. KPFA archives no. BB 1849. Audiotape. Text was published in City of San Francisco Oracle (C46).

F7 Give Peace a Chance. Apple 1809 (S45-X46904). London, 1969. 45 rpm record. Song composed by John Lennon and Paul McCartney, and recorded in Room 1742, Hotel La Reine Elizabeth, Montreal on May 31, 1969 by Lennon and Yoko Ono. Timothy and Rosemary Leary were present, provided back-up vocals and are mentioned in the lyrics.

F8 You Can Be Anyone This Time Around. Douglas 1. New York, 1970. Long-playing record album. Fold-open cover has collages by Kelley/ Mouse Studios printed in various colors incorporating portraits of author in circular frames. Side 1: You Can Be Anyone This Time Around/ What Do You Turn On When You Turn On. Produced in a recording studio. Side 2: Live and Let Live. Side 1 is a studio session from prepared notes; side 2 is a live broadcast interview in a nightclub with background music of Jimi Hendrix and the Band of Gypsies.

F9 Seven Up. Timothy Leary and Ash Ra Tempel. Metronome Records KK 58001 Stereo. W. Ger.; 1973. Long-playing record album. Fold-open cover in multicolors featuring elaborate design by Walter Wegmüller. Side 1: Space (Downtown, Power Drive, Right Hand Love, Velvet Genes.) Side 2: Time (Timeship, Neuron, SHe [sic]). Lyrics by Timothy Leary and Brian Barritt to the music of Ash Ra 


\section{TURN ON, TUNE IN, DROP OUT Timothy Leary,Ph.D.}

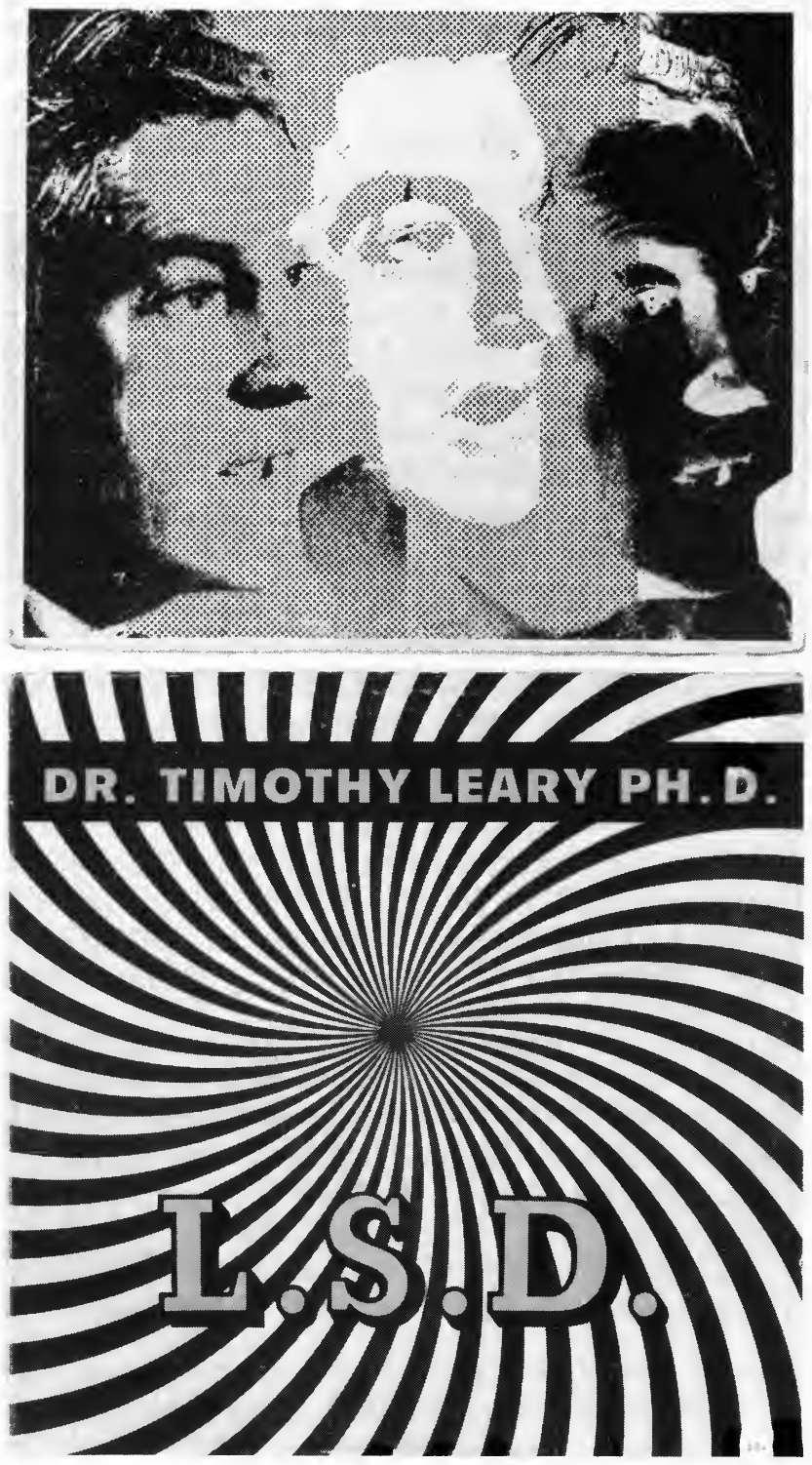

F1 (top) and F2: Leary's first two record albums were informational talks on psychedelic experiences. 


\section{THE PSYCHEDELIC EXPERIENCE}

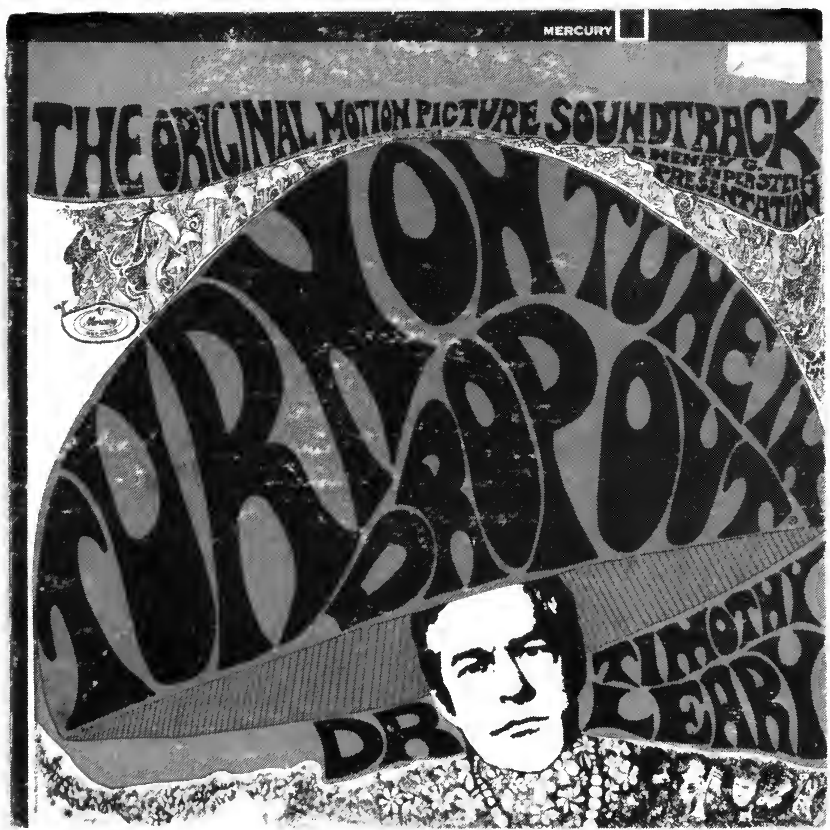

F3 (top) and F5: Two dramatic renderings of an LSD trip, performed by Leary and associates. Courtesy Folkways Records. 
Tempel. Recorded at the Bern Festival, Bern, Switzerland, in 1972. Re-release: PDU Records. Pld. SQ 5097. Italy, 1974. Jacket newly designed. Front cover: purple, orange and yellow psychedelic design surrounding triangular photograph of the author in recording studio. Back cover: purple and yellow design, with liner notes. Cover design by Peter Geitner. Portions of Seven Up were re-released on Gilles Zeitschiff ("musikeinblendungen von den LP 'Seven Up'" with other music). Produced by Gilles and Klaus Schulze. Cosmic Courier KM 58.012. Long-playing record album. Berlin: Ohr Musik Produktion, 1974. In addition to selections from Seven Up, Leary is credited on the following cuts: "The Electronic Scene," "Electronic Rock Zeitalter," "So Beautiful," and "The Queen of Sunshine."

F10 Forum Letter. Produced and distributed by P.R.O.B.E. San Francisco, 1973. Four-track reel-to-reel and audiotape cassette. The text of Leary's Forum Letter (C83) recorded in Folsom Prison, Calif. P.R.O.B.E was a prison reform organization cofounded by Leary and other prisoners.

F11 Interview in Vacaville Prison. Vacaville, Calif., 1973. Audiotape cassette. Unauthorized production of an interview between Leary and Wesley Hiler, Vacaville prison psychologist, dealing with "Higher Intelligence," space migration and other matters. The tape was smuggled out of prison and played on local radio stations.

F12 Symposium sponsored by the Institute for the Study of Consciousness. Berkeley, Aug. 1976. Thirteen audiotape cassettes. Participating in the symposium besides Leary are Robert Anton Wilson, Jack Sarfatti, Saul-Paul Sirag, Karl Pribam, Nick Herbert, George Koopman and P. Fleissel. Limited number of sets produced; not for commercial release.

F13 Space Migration. Star Trek Update audiotape cassette no. 11. San Francisco, 1976. Leary's talk at the Star Trek Convention in Oakland, Calif., Aug. 1976.

F14 Space Psychology. Faces West Productions audiotape cassette no. 14. San Francisco, 1976. A continuation of Leary's appearance at the Star Trek Convention, Aug. 1976 (see F13).

F15 Address delivered at the University of Arizona, Tucson, Oct. 21, 1976. Three audiotape cassettes. A transcription of this talk is produced in The Intelligent Agents (A21). The tapes were not released commercially.

F16 Timothy Leary: His Version of the World and History. New Dimensions audiotape no. 1223. San Francisco, 1977. Address delivered in Berkeley, Jan. 1977. 
F17 The Joyful Wisdom Program. Programs 1-7. San Diego, Huntington Beach and Los Angeles, 1977. Seven long-playing record albums in white sleeves without jackets as issued. Produced by George A. Koopman for WKGB, San Diego, each record features an interview with Timothy Leary as well as other segments (news, commercials, dramatizations) written or performed by him. Other participants included Grace Slick, Lindsay Wagner and Cheech and Chong. Approximately 100 copies of each record were distributed for promotional purposes to about thirty radio stations; there was no commercial release. Program 1 was re-released.

F18 LSD: A Generation Later (Colloquium I). New Dimensions audiotape cassette no. 1221. San Francisco, 1978. Interviews and opinions recorded during the conference weekend. Participants include Leary, Allen Ginsberg, Stanley Krippner, Ralph Metzner and Richard Alpert (Ram Dass).

F19 Living in Space. New Dimensions audiotape cassette no. 1202. San Francisco, 1978. Discussion and talks featuring Leary, Gerard O'Neill, Jacques Vallee and Stewart Brand on the subject of space colonization.

F20 Timothy Leary \& Robert Anton Wilson. New Dimensions audiotape cassette no. 1172. San Francisco, 1978. Discussion of space migration, life extension, cyborgs and clones.

F21 The Creation of the Future. Ringlemann Productions. San Francisco, 1979. Two audiotape cassettes. Leary's address delivered in San Francisco, Jan. 24, 1979.

F22 The Nova Convention. Giorno Poetry Systems Records. LP-GPS 014-015. New York, 1979. Long-playing, double-record album. Side 4 contains a panel discussion with Timothy Leary, William S. Burroughs, Brion Gysin, Robert Anton Wilson and Les Levine, recorded at the Intermedia Theater, New York, Sat., Dec. 2, 1978. See $\mathrm{J} 400$.

F23 LSD: The Future of Consciousness (Colloquium II). Audiotape cassette CC-4. New Age Communications. Pacific Grove, Calif., 1981. Conference held at the University of Calif., Santa Cruz, July 10, 1981. Leary chaired panel discussion of "Higher Intelligence and Creativity," heard on this cassette. See B40 and C126 for printed versions.

F24 The Power of Imprinting. Big Sur, Calif., 1982. Dolphin Tapes. Two audiotape cassettes. Leary's talk at Esalen Institute, July 1982, on the twenty-four stages in the evolution of intelligence, and on methods of re-imprinting. 
F25 A Day with Timothy Leary. Dolphin Tapes. Big Sur, Calif., 1982. Four audiotape cassettes. Dialogue between Leary and a group at the Alaron Center, Sausalito, Calif., Aug. 1982, on the evolution of intelligence and other topics. Moderator is Francis Jeffrey.

F26 The Neuronaut Returns. New Dimensions audiotape no. 1815. San Francisco, 1983. Leary talks about his just-released autobiography, Flashbacks (A25).

F27 Timothy Leary. Transmitter Cassetten TC 01 (single cassette). Tim Leary Live im Sauerland (four-cassette pack). Transmitter Cassetten TC 73-76. Lohrbach, W. Ger., 1983. Documentary of Leary's visit to West Germany in 1983 - his first visit to Europe since he fled Switzerland ten years earlier.

F28 The Final Taboo. Trance Port Tapes. 1984. Audiotape cassette. Lecture delivered by "America's foremost advocate of human potential and higher brain function" (promotional literature).

F29 American Culture: 1945-1985. Big Sur Recording no. 1990. Sausalito, Calif., 1985. Audiotape cassette. Talk on cultural changes in American culture since the Atomic Age began. 


\section{G.}

\section{Films and Television Shows with Appearances by Timothy Leary}

G1 Psychology training film (title unknown). Cambridge, Mass. (1960?). $16 \mathrm{~mm}$ film. Produced by the Harvard psychology department, with Leary and Richard Alpert playing role models for psychological types and situations.

G2 Wedding at Millbrook. Produced by the Maisle Brothers. New York, 1964. $16 \mathrm{~mm}$ (or $35 \mathrm{~mm}$ ) film. A commercially released thirty-minute documentary film on life at the Castalia Foundation, Millbrook, N.Y. Stills from the wedding conducted by Leary appear in Start Your Own Religion (A6).

G3 Goldfever. Produced by Donald Nestingen. New York, (1965?). 16mm film. Eight-minute film about Leary's Millbrook, N.Y. commune, directed by Leary.

G4 Report from Millbrook. Produced and directed by Jonas Mekas. New York, $1966.16 \mathrm{~mm}$ color film. Twelve-minute film by the underground filmmaker and critic, showing the Millbrook estate with a soundtrack of an interview with the sheriff who arrested Leary in a raid on his commune.

G5 The Merv Griffin Show. Television production. New York, 1966. Videotape. Leary was interviewed by Griffin on this popular, nationally-broadcast program.

G6 Turn On, Tune In, Drop Out. Produced by Henry G. Saperstein for Benedict Pictures. Hollywood, 1967. 35mm color film. A feature film based upon Leary's "psychedelic celebrations" staged in a number of cities the previous year, with Timothy Leary in the role of the Guide, Ralph Metzner as the Voyager, and Rosemary Woodruff as the Divine 
Connection. This movie was suppressed within one week of its premiere in Los Angeles, and has not been re-released. See F5 for original soundtrack album.

G7 The Pursuit of Pleasure. Produced by the National Broadcasting Company. New York, 1967. Television show with appearances by and interviews with Leary, Hugh Hefner and Ralph Ginzburg.

G8 The Mind Alchemists. Produced and directed by Michael Tuchner for the BBC. London, Aug. 18, 1967. "A documentary about America's new breed of revolutionaries and their gospel of LSD" (as described by Radio Times, London), with participation of Leary, Allen Ginsberg, Humphry Osmond, et al.

G9 LSD: Lettvin vs. Leary. Produced by National Educational Television. New York, 1968. 16mm film. Fifty-one minute film of the nationally televised debate between psychologists Leary and Jerome Lettvin on the value of LSD.

G10 Skidoo. Feature film produced and directed by Otto Preminger. Hollywood, 1968. 35mm color film. Leary appeared in a promotional trailer for this feature film starring Jackie Gleason and Groucho Marx. Leary was also consultant on the set.

G11 From Pot to Psychedelics. Produced by National Educational Television. New York, 1968. Television show containing an appearance by Leary.

G12 Untitled film, produced and directed by Lenny Lipton. Los Angeles, Calif., 1968. Short, silent film by the underground journalist and filmmaker, showing Leary at his home in the Berkeley hills.

G13 Diaries, Notes and Sketches. Produced and directed by Jonas Mekas. New York, 1969. 16mm film. Underground film containing a brief appearance by Leary.

G14 Give Peace a Chance. Room 1742, Queen Elizabeth Hotel, Montreal, May 31, 1969. Videotape. The bedroom recording session of the famous antiwar song (see F7) written by John Lennon and Paul McCartney, and sung by Lennon and Yoko Ono, with back-up vocals by Timothy and Rosemary Leary.

G15 Release. Produced by Vienna Filmkollectiv. Vienna, 1972. 16mm film. Documentary film about heroin addiction with appearances by Timothy Leary and Joanna Harcourt-Smith. Filmed while Leary was en route from Switzerland to Austria.

G16 At Folsom Prison (alternately titled: Dr. Timothy Leary Speaks His Mind From Folsom Prison). Produced by Joanna Harcourt-Smith at 
Folsom and San Francisco, Calif., 1973. 16mm color film. Twenty-minute interview conducted by Joanna Harcourt-Smith with Leary under guard at Folsom Prison.

G17 Cheech and Chong's Nice Dreams. Produced by Cheech Marin and Thomas Chong for Columbia Pictures. Hollywood, $1980.35 \mathrm{~mm}$ color film. Feature film starring Cheech and Chong with a cameo appearance by Leary in the role of a mad doctor.

G18 Interview with Timothy Leary. Produced by Shirley Clarke, c. 1982. Videotape. Apparently unreleased.

G19 The Faces of Culture. Produced for the Public Broadcasting Service by KOCE, Channel 50, Huntington Beach, Calif., 1983. Videotape. Leary appears on this television broadcast.

G20 Return Engagement. Produced by Carolyn Pfeiffer for Island Alive Pictures. Directed by Alan Rudolph. Los Angeles, 1982. 35mm color film. Ninety-minute documentary film on the Timothy Leary-G. Gordon Liddy debates. Opened in 1983 at the Cannes Film Festival; commercially released in fall 1983.

G21 We're All DEVO: A Retrospective of DEVO's Music-Video Classics. Produced by Chuck Staler. Directed by Gerald V. Casale. A Sony Video LP. Los Angeles, 1984. Fifty-six-minute video anthology with cameo appearance by Timothy Leary as Dr. Byrthfood.

G22 Laying It On the Line. Music-video performed by the Jefferson Starship. 1984. Videotape. Contains footage of Leary and G. Gordon Liddy in debate from Return Engagement (G20).

G23 Possessed to Skate. Music-video performed by Suicidal Tendencies. 1986. Videotape. Leary performs cameo role of the father of a youthful skateboarder. 


\section{H. \\ Works Edited}

H1 Newsletter \#1 [of the] Research Program on Consciousness-Altering Substances. Cambridge, Mass. Feb. 1962. Newsletter (apparently the only one published) of the psilocybin research group at the Center for Research in Personality, Harvard University. Members included Leary, Richard Alpert, Ralph Metzner, Gunther Weil and Michael Hollingshead. Leary was one of the editors and also printed a letter he wrote to the FDA (see C17).

H2 IFIF Newsletter, nos. 1-3 (May-Nov. 1963). Boston. Castalia Foundation. Leary was one of the editors of the newsletter of the International Federation for Internal Freedom. A ten-page "Bibliography of Psychedelic and Related Research," dated May 1963, was distributed as a supplement to no. 1 .

H3 Psychedelic Review, nos. 1-10 (1964-69). Cambridge, Mass. and New Hyde Park, N.Y. Leary acted in the capacity of editor, contributing editor or consulting editor of these issues.

H4 The Psychedelic Reader. New Hyde Park, N.Y.: University Books, 1965. Coedited with Gunther M. Weil and Ralph Metzner. See B8.

H5 Spit in the Ocean, no. 3 (Fall, 1977). Issue devoted to "Communication with Higher Intelligence." Edited by Leary while he was serving his last year in prison. Ken Kesey and Ken Babbs produced this magazine in Oregon. 


\section{I. \\ Unpublished Writings and Talks}

I1 Tomorrow We Live. Novel written while Leary was a cadet at West Point. 1940.

I2 "The Role of Level III (Projective) Data in Prediction." Address delivered at a symposium, "The Use of Projective Techniques for Predicting the Outcome of Psychotherapy," held at the annual meeting of the American Psychological Association, St. Louis, Sept. 1. Cited in: American Psychologist 15, no. 7 (July 1960): 388.

I3 "Diagnosis and Treatment of Psychotherapy Research." Address delivered at a symposium, "The Outlook for Psychotherapy Research," held at the annual meeting of the American Psychological Association, Sept. 2, St. Louis. Cited in: American Psychologist 15, no. 7 (July 1960): 421.

I4 Static and Exstatic [sic] Dimensions of Consciousness and their Communication. Book-length typescript, submitted to University Books, New Hyde Park, N.Y. 1964.

I5 Psychedelic Theory [and] The Psychedelic Moment. Book-length typescript, intended for publication by Castalia Foundation, Millbrook, N.Y. 1965.

I6 Hedonic Psychology (alternately titled: The Psychology of Pleasure). Transcript of five lectures delivered at the Free University of Berkeley, Feb. 1969. A small portion of the text was published in Psychology Today, Jan. 1973 (C80).

I6a "A Book for Oscar . . Being a Treatise on Space-Time written in Alger's Sun February 27, 1971." Manuscript, 17 pp., illustrated with diagrams, written in a notebook in Algiers, 1971. See Confessions of $a$ Hope Fiend (A14), pp. 257-58. (Collection of Gerald Goldfarb, Los Angeles.) 
17 "Pact with Higher Intelligence." Typescript, 13 pp., written in Folsom Prison, Calif., 1974.

I8 "The Child's Primer of Neurologics." Twenty-six-line poem in typescript on the effects of various drugs. Written in Folsom Prison, Calif., 1975.

19 "Extraterrestrial Migration: A 'Real Estate' Proposal." Typescript, 26 pp., designed to be a brochure privately printed in an edition of eight copies. 1977.

110 "The Psychological Effects of High Orbital Migration." Address delivered at a meeting of the American Astronautical Society on the industrialization of space, San Francisco, Oct. 18, 1977.

I11 High Orbit. A Novel. Typescript dated July 8, 1977. 44 pp. A second copy of the same typescript bears the title The Spirit of ' 76.

112 Untitled work. 16 pp. typescript. 1977. Apparently an outline of a film based on an unpublished novel, High Orbit (a.k.a. The Spirit of '76).

113 Speech delivered at Drew University, Madison, N.J., 1977. Typescript, $30 \mathrm{pp}$.

114 Interview in LSD: A Generation Later. Portion of an unpublished transcript of a symposium held at the University of California-Santa Cruz, Oct. 14-15, 1977.

15 "The Game of Life. III: The 21st Century I Ching." Typescript, 56 pp., 1979, constituting an unpublished section of The Game of Life (A23).

116 "After the Sober, Serious, Safe and Sane '70s, Let Us Welcome the Return of LSD.” Typescript, 36 pp. 1980.

I17 Interview in Colloquium II: The Future of Consciousness. Portion of an unpublished transcript of a symposium held at the University of California-Santa Cruz, July 9-11, 1981.

I18 Speech delivered to Boston Ad Club, May 8, 1984. 20-page transcript made from tape recording.

119 "Life Cycles: 24 Love Songs for Each Stage of Life." Typescript, 20 pp., dated May 25, 1984. Revision of lyrics for rock songs begun in 1972 when Seven Up (F9) was produced.

I20 "Pornography Is Good; Scornography Is Bad." Typescript, 15 pp., 1986. A denunciation of the recommendations of the Meese Pornography Commission. 


\section{$\mathbf{J}$. \\ Book, Articles, Songs and Films about Timothy Leary}

\section{7}

J1 "Tim Leary Is Named Editor of Next Year's Recorder." Classical Recorder (Published by the Students of Classical High School), Springfield, Mass. (June 4):1. Unsigned story includes mention of Leary's accomplishments as a sports reporter and newswriter, and his "hope of being appointed to West Point." With photograph of Leary at 16.

\section{8}

J2 The Blue and White. A Yearbook (Published by the Pupils of Classical High School). Springfield, Mass., pp. 45, 62-64, 85. Leary's high school graduation class yearbook, with photographs and references, including a caricature of him as editor of the student newspaper and his appearance in a satirical dialogue, "The Prophecy of the Class of 1938."

\section{4}

J3 Bach, George R. Intensive Group Psychotherapy (New York: Ronald Press), pp. 262, 331, 386, 387. "Levels of psychological processes" in group therapy "have recently been given formal expression" [in Leary's doctoral dissertation (AA5). In Leary's 1951 paper (AA7)] "the variety and quality of emotional intensity of roles can be observed to change in group psychotherapy." 


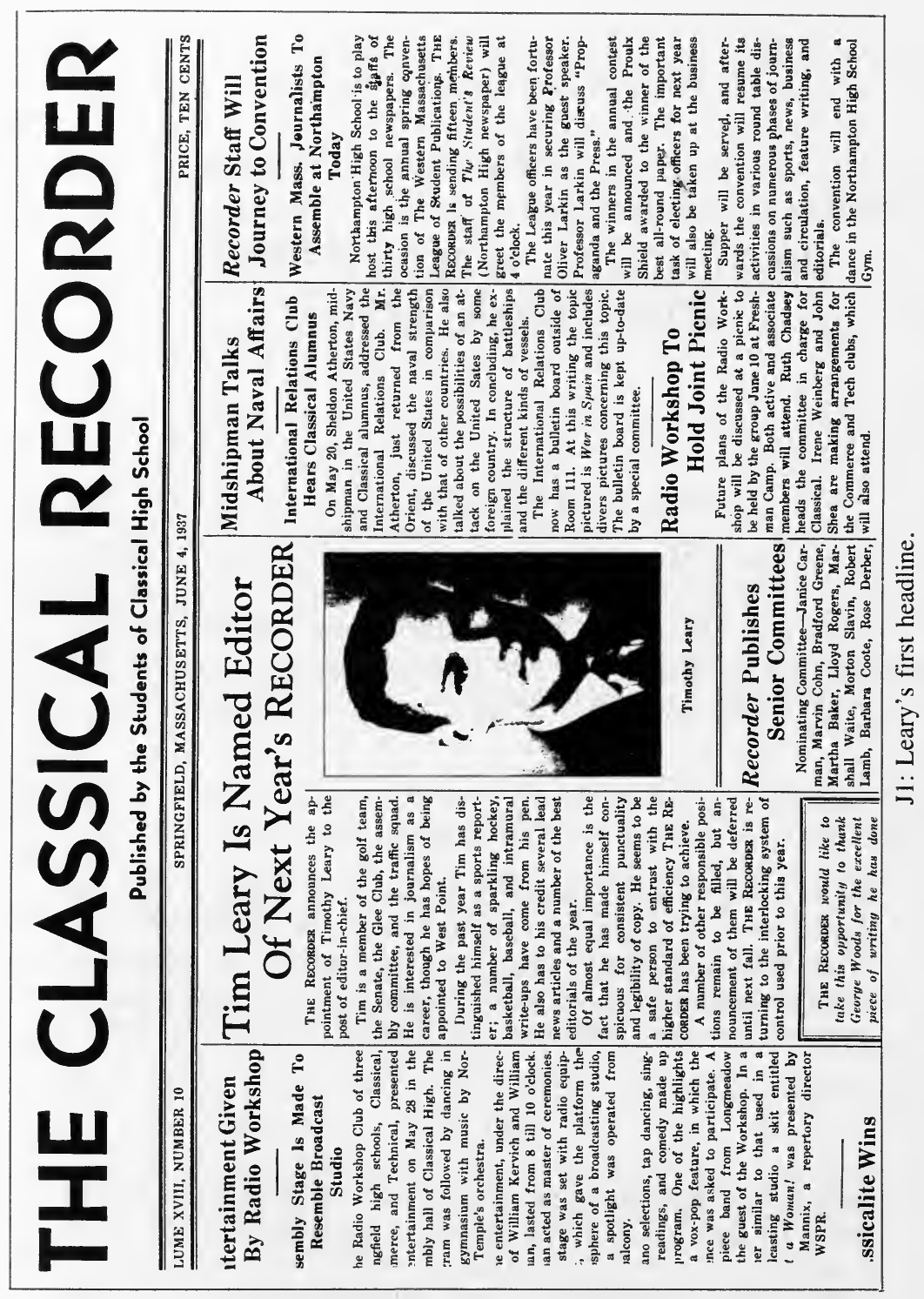




\section{5}

J4 LaForge, Rolfe, and Robert F. Suczek. "The Interpersonal Dimension of Personality: III. An Interpersonal Check List." J. Personality 24, no. 1 (Sept.):94-112. The third and concluding part of AA7 and AA10. The Interpersonal Check List is discussed in detail and reproduced in its final form (fig. 1). Leary's contribution is acknowledged.

J5 Roback, A. A. (ed.). Present-Day Psychology. (New York: Philosophical Library), p. 211. "Leary and Freedman (1951) [AA7] have attempted to work out a scheme whereby the interpersonal mechanisms could be scored and applied to interaction in a group."

\section{7}

J6 Corsini, Raymond J. Methods of Group Psychotherapy. (New York: McGraw-Hill), p. 107. Reference is made to Coffey, Freedman, Leary and Ossorio (1950) [C5].

J7 Edwards, Allen L. The Social Desirability Variable in Personality Assessment and Research. (New York: Dryden Press), pp. 10-11. Figure 2 (p. 11) is based on Leary's Interpersonal Check List; reference is made to to Multilevel Measurement of Interpersonal Behavior (A2).

J8 Schutz, William C. "Levels and Dimensions of Personality." Contemporary Psychology, no. 9 (Sept.):27-29. Lengthy review of Interpersonal Diagnosis of Personality (A3), with photo of Leary. "The work unquestionably represents a major advance in clinical diagnosis."

\section{8}

J9 Armstrong, R. G. "The Leary Interpersonal Check List: A Reliability Study." J. Clinical Psycholology 14:393-94.

J10 Heyns, Roger W. "Social Psychology and Group Processes," Annual Review Psychology 9:444. " "A Theory and Methodology for Measuring Fantasy and Imaginative Expression' [AA15] is certainly of interest to the many students of TAT-type measures."

J11 Kelly, George A. "The Theory and Technique of Assessment," Annual Review Psychology 9:337. Leary's "emphasis upon the time-binding of impulse," discussed in Interpersonal Diagnosis of Personality (A3), is among the "new theories afoot which may profoundly affect assessment in the future." 
J12 Schutz, William C. FIRO: A Three-Dimensional Theory of Interpersonal Behavior. (New York: Holt, Rinehart \& Winston), pp. 36, 48-49. "In a stimulating series of articles culminating in Leary's book [A3], Leary and the Kaiser group . . . have presented an analysis of interpersonal behavior based on examination of interview protocols, test records, group therapy meetings, and other material."

J13 Snyder, William U. "Psychotherapy." Annual Review Psychology 9:353-55. Review of Interpersonal Diagnosis of Personality (A3), "perhaps the most important clinical book to appear this year."

\section{0}

J14 Dahlstrom, W. Grant, and George S. Welsh. An MMPI Handbook. (Minneapolis: University of Minnesota Press), pp. 344-45, 362-63 passim. Numerous references are made to Interpersonal Diagnosis of Personality (A3), Leary \& Coffey (AA11) and Barron \& Leary (AA13).

J15 Klopfer, Walter G. The Psychological Report: Use \& Communications of Psychological Findings. (New York: Grune \& Stratton), pp. 65-67, 72. Description of three of Leary's five levels of the personality as given in Interpersonal Diagnosis of Personality (A3).

J16 Uhr, Leonard, and James G. Miller. (eds.). Drugs and Behavior. (New York: John Wiley \& Sons), pp. 512-13. "Leary (1957) [A3] and his associates have developed objective rating methods for measuring interpersonal behavior consistent with the general tenets of [Sullivan's] theory."

\section{1}

J17 Foa, U. "Convergences in the Analysis of the Structure of Interpersonal Behavior." Psychology Rev., no. 5:341-55. Analysis of the Interpersonal Behavior Circle.

J18 Frank, Jerome D. Persuasion and Healing. (Baltimore: The Johns Hopkins Press), pp. 16, 33. Leary and Barron (AA13) and Leary's Interpersonal Diagnosis of Personality (A3) present "a good account of [the reciprocal nature of human transactions]."

J19 McClelland, David C. The Achieving Society. (Princeton, N.J.: Van Nostrand), p. xi. Leary is acknowledged in preface "for general sympathetic advice and assistance." The author, chairman of the psychology department at Harvard, offered Leary a position there. 
J20 Phillips, Jeanne S., Ruth G. Matarazzo, et al. "Relationships between Descriptive Content and Interaction Behavior in Interviews." In Psychotherapy Research, ed. G. Stollak, B. Guerney and M. Rothberg. (Chicago: Rand-McNally, 1966), pp. 470-78. Reference to "the promising but overcomplex system developed by Leary and his colleagues.

J21 Shibutani, Tamotsu. Society and Personality: An Interactionist Approach to Psychology. (Englewood Cliffs, N.J.: Prentice-Hall), p. 366. "Interpersonal Diagnosis of Personality [A3, is] a thoughtful attempt to set up diagnostic procedures for the systematic study of the ways in which people consciously or unconsciously approach one another."

J22 Stagner, Ross. Psychology of Personality. (New York: McGraw-Hill), p. 166 and fig. 8.2. "Leary (1956) [A2] offers an approach which defines a trait in terms of a consistent pattern of interpersonal relationships." Reproduction of the Interpersonal Check List.

J23 Wylie, Ruth C. The Self-Concept: A Review of Methodological Considerations and Measuring Instruments. 2d ed., rev. (Lincoln: University of Nebraska Press, 1974), vol. I, pp. 213-19. Description and analysis of the Interpersonal Check List. "The data reported by Leary (1957) [A3] are by far the most extensive of any which compare self-concept measures with patterns of diagnosed maladjustment."

\section{2}

J24 Lieberman, E. James. "The Ethical Neutrality of LSD" Bull. Atomic Scientists 18, no. 6 (June):41. Counter-response by the author of the article to whom Leary et al. responded in the previous issue (C19).

J25 Fischer, Roland. "Psychochemicals." Bull. Atomic Scientists 18, no. 7 (Sept.):36. Response to the article by Lieberman (J24) and the subsequent letter by Leary, et al. (C19) that appeared in earlier issues, followed by Lieberman's response.

J26 Lorr, Maurice. "Approaches to Interpersonal Behavior Schema." Paper read at the 7th Annual Research Conference on Chemotherapy Studies in Psychiatry," Cincinnati. (Washington, D.C.: GPO). Analysis of the Interpersonal Behavior Circle.

J27 Luborsky, Lester, and Hans H. Strupp. "Research Problems in Psychotherapy: A Three-Year Follow-Up," in Research in Psychotherapy, ed. Strupp and Luborsky. (Washington: American Psychological Association), pp. 308-29. Reference to "the promising but overcomplex system by Leary and Gill [AA16, B1]." 
J28 McDonald, R. L. "Personality Characteristics of Freshman Medical Students as Depicted by the Leary System." J. General Psychology 100:313-23.

\section{3}

J29 Grossman, Edward A. "The Undergraduate: Some Aspects of Consciousness at Harvard." Harvard Alumni Bull. (Jan. 12): 304-5, 311. A summary of the Harvard controversy over the distribution of psilocybin to undergraduates.

J30 [Lee, Paul A., and Ralph Metzner]. "The Subjective After-Effects of Psychedelic Experiences: A Summary of Four Recent Questionnaire Studies." Psychedelic Rev., no. 1 (June):18-26. One of the four studies is described as the "Leary Study" ("Reactions to Psilocybin Administered in a Supportive Environment [AA45])."

J31 Dusheck, George. "Paradise Lost by Mexico LSD Colony." San Francisco News-Call Bulletin (July 2). Lengthy account of the expulsion of Leary and members of the Psychedelic Training Center established in Zihuatenejo.

J32 Gordon, Noah. "The Hallucinogenic Drug Cult." Reporter, no. 3 (Aug. 15):35-43. Account of the Psychedelic Research Project at Harvard.

J33 Mayer, Martin. "Getting Alienated with the Right Crowd at Harvard." Esquire (Sept.). Critique of ex-Harvard professors Leary and Richard Alpert and their new organization, International Federation for Internal Freedom.

J34 Metzner, Ralph, and Gunther Weil. "Predictive Recidivism: Base Rates for Massachusetts Correctional Institution, Concord," J. Criminal Law, Criminology, Police Science 54, no. 3 (Sept.):307-16. The results of psilocybin therapy with prisoners carried on by the Psychedelic Research Project at Harvard.

J35 Gaines, Bob. "LSD: Hollywood's Status-Symbol Drug." Cosmopolitan (Nov.):78-81. Includes an account of the Harvard drug controversy.

J36 Weil, Andrew T. "The Strange Case of the Harvard Drug Scandal." Look (Nov. 5):38, 43-44, 46, 48. On the "consciousness-expansion" research at Harvard and the subsequent dismissals of Leary and Richard Alpert.

J37 Kobler, John. "The Dangerous Magic of LSD." Saturday Evening Post (Nov. 2):30-41. Reference is made to Leary and Alpert's activities at Harvard, IFIF, Zihuatenejo and Millbrook, with extensive quotation. 
J38 Barron, Frank. Creativity and Psychological Health. (Princeton, N.J.: Van Nostrand), p. 76 passim. Leary's close associate and coauthor (AA13) relates how he "commended the [psilocybin] mushroom to the attention of a colleague of mine at Harvard University, Tim Leary, [who] became interested in its possibilities as a vehicle for inducing change in behavior." Perhaps the earliest reference in a psychology book to Leary's drug researches.

J39 Central Intelligence Agency. Memorandum for the Record. Subject: International Federation for Internal Freedom (IFIF). Alpert, Richard, Ph.D., Leary, Timothy F., Ph.D. Drugs, Mind Affecting, Agency Policy Regarding. Washington, D.C., Nov. 1, 1963. Two-page typed memo regarding the need for surveillance of Leary and Alpert, signed "Chief/SRS/OS."

J40 Heard, Gerald. The Five Ages of Man. (New York: Julian Press), pp. 192, 237-39. References to Aldous Huxley's letters about Leary, to a 1964 letter from Leary to Heard and to Leary's 1962 visit to Ananda Ashram.

J41 Mann, John. Frontiers of Psychology. (New York: Macmillan), pp. 219-20. Discussion of the work of "the Kaiser group under the general direction of the American psychologist Tim Leary [which is ] interesting as a prototype of interlevel analysis."

J42 Rethlingshafer, Dorothy. Motivation as Related to Personality. (New York: McGraw Hill), pp. 291-92. Reproduces and discusses "a scoring scheme for interpersonal relations" from a 1959 textbook closely based upon Leary's Interpersonal Check List.

J43 Rosenbaum, Max and Milton Berger. (eds.). Group Psychotherapy and Group Function. (New York: Basic Books), p. 8. "Leary (1957) [A3] has developed a very elaborate schematic system where his principle of reciprocal relationships is charted. Leary worked with an eight-dimensional multilevel system to predict the individual's behavior in group psychotherapy and the effectiveness of the group as a whole."

\section{4}

J44 Krippner, Stanley. "The Hypnotic Trance, the Psychedelic Experience, and the Creative Act." American J. Clinical Hypnosis 7, no. 2 (Oct.):146. Religious experiences of LSD users noted by Leary and Walter Clark.

J45 Adams, Henry B. “ 'Mental Illness' or Interpersonal Behavior?” American Psychologist. "The universal applicability of the basic dimensions 
delineated in Leary's system for the description and classification of all interpersonal behavior."

J46 Barber, T. X., and D. S. Calverley. "Hypnotizability, Suggestibility, and Personality. IV: A Study with the Leary ICL." British J. Social and Clinical Psychology, no. 3: 149-50.

J47 Bergin, Allen E. "Some Implications of Psychotherapy Research for Therapeutic Practice," in Psychotherapy Research, ed. G. Stollak, B. Guerney and M. Rothberg. (Chicago: Rand-McNally), pp. 118-19. Reproduces a table "from Cartwright's reanalysis (1956) of the well-known Barron \& Leary study (1955) [AA13]."

J48 Downing, Joseph J. "Zihuatanejo: An Experiment in Transpersonative Living," in Utopiates: The Use and Users of LSD-25, ed. R. Blum and Associates. (New York: Atherton), pp. 142-77. Account of the Psychedelic Training Center established by Leary and asssociates in Zihuatenejo, Mexico in 1963.

J49 London, Perry. The Modes and Morals of Psychotherapy. (New York: Holt, Rinehart \& Winston), p. 187. "The concept of psychotherapy as a reciprocal interaction" is based on a hypothesis of Leary.

J50 Vernon, Philip E. Personality Assessment: A Critical Survey. (London: Methuen), pp. 114-15, 279-80 passim. Description of Leary's interpersonal diagnostic system.

J51 Whitaker, Dorothy Stock, and Morton A. Lieberman. A. Psychotherapy through the Group Process. (New York: Atherton), p. 242. Leary's contribution to group therapy based on his Interpersonal Diagnosis of Personality (A3).

\section{5}

J52 Krassner, Paul. "Dr. Leary-Or How I Learned to Transcend Ego and Expand My Consciousness." The Realist, no. 55 (Jan.):1. A report on a "consciousness expansion" weekend with Leary at Millbrook.

J53 Bieberman, Lisa. Bull. Psychedelic Information Center (Cambridge, Mass.), nos. 5, 8, 12, 14, 18 (1965-68). Running critical commentary of Leary's activities during that period.

J54 Heard, Gerald. "Rebirth Without Fear," Psychedelic Rev., no. 5:110-18. Review of The Psychedelic Experience (A4).

J55 Heller, Kenneth, and Arnold P. Goldstein. "Client Dependency and Therapist Expectancy as Relationship Maintaining Variables in 
Psychotherapy," J. Consulting Psychology 25, no. 5:371-75. Authors quote from Barron and Leary (AA13) to support the contention that people attracted to psychotherapy interpret even minimal clinic contact as benefiting them in some way.

J56 Marsden, Gerald. "Content-Analysis Studies of Therapeutic Interviews: 1954 to 1964," Psychological Bull. 63: 298-321. "A system devised by Leary and Gill (1959) [AA16; B1] is an omnibus system designed to allow for coding almost all verbalization of both patient and therapist in what is probably the most complex category structure offered to date." There is also reference to Leary's "Huck and Jim in their Interpretive Balloon" (C16).

J57 McGlothlin, William M. "Comments." ETC., no. 22:460-62. Remarks on the preceding article by Leary: "Languages: Energy Systems Sent and Received" (AA46; C35).

J58 Adams, Henry B. "A Case Utilizing Sensory Deprivation Procedures," in Case Studies in Behavior Modification, ed. L. P. Ullman and L. Krasner. (New York: Holt, Rinehart \& Winston), pp. 164-68. A case history is presented utilizing the MMPI and the Interpersonal Check List, "which were scored according to the multilevel system of interpersonal diagnosis (Leary 1956) [A2]".

J59 Blank, Leonard. Psychological Evaluation in Psychotherapy: Ten Case Histories. (Chicago: Aldine), p. 9. The Interpersonal Check List is one of a battery of tests used throughout the book.

J60 Cohen, Sidney. "Uncanny Power of the Hallucinogens." The Drug Takers. (New York: Time), pp. 100, 102. Chronicles Leary and Richard Alpert's expulsion from Harvard, with photographs from Harvard period.

J61 Kavaler, Lucy. Mushrooms, Molds, and Miracles: The Strange Realm of Fungi. (New York: Day), pp. 167-78. Chapter "The Mind Drug Madness" largely deals with history of psychedelic research at Harvard and IFIF.

J62 Romano, Robert L. "The Use of the Interpersonal System of Diagnosis in Marital Counseling," in Theories of Personality: Primary Sources and Research, ed. G. Lindzey \& C. S. Hall. (New York: Wiley \& Sons), pp. 144-50. Refers to Interpersonal Diagnosis of Personality (A3) and "The Interpersonal Dimension of Personality" (AA7).

J63 Stieper, Donald R., and Daniel N. Wiener. Dimensions of Psychotherapy. (Chicago: Aldine), p. 98. "Perhaps the most ornate and complex set of devices for assessing the process of psychotherapy has been developed by Leary and co-workers." 
J64 Time/Life editors. The Drug Takers. (New York: Time), pp. 100-102. Summarizes Leary and Richard Alpert's fall from grace from Harvard to Millbrook, with two photos.

J65 Tyler, Leona E. The Psychology of Human Differences. 3d ed. (New York: Appleton-Century Crofts), pp. 176-77. "The interpersonal aspects of behavior . . . was elaborated most thoroughly by a research group of the Kaiser Foundation and presented in a book by Leary (1957) [A3] The Interpersonal Check List has constituted a useful tool in research projects of many kinds." Interpersonal Behavior Chart reproduced, figure 30.

\section{6}

J66 Farrell, Barry. "A Psychic Revolution." Life (Mar. 12):31-33. Includes quotation from Leary and Alpert's "The Politics of Consciousness" (AA42).

J67 Luce, Henry. "LSD: Control, Not Prohibition." Life (Apr. 29). "Instead of harassing a would-be martyr . . . society would do better to figure out how law can best control [LSD]."

J68 "Millbrook Raid: An Eyewitness Report." East Village Other (Apr.). Description of the Apr. 17, 1966 police raid on Leary's commune.

J69 Bess, Donovan. "LSD: The Acid Test." Ramparts, no. 12 (Apr.):44. How Leary and Alpert have taken over (from Huxley) "the psychedelic preaching job," with reference to The Psychedelic Experience (A4).

J70 Mannes, Mayra. "Raid on Castalia." Reporter 34 (May 19):27-28. Description of the sheriff's raid on Leary's commune lead by G. Gordon Liddy.

J71 Davenport, John. "LSD: A New Religion Comes to Washington." The Washingtonian, no. 10 (July):22-25, 54-56. Leary and Art Kleps testify at a Senate Subcommittee hearing about LSD.

J72 Mannes, Mayra. "Young People and LSD: A Talk with Susan Leary." McCalls, no. 93 (July):14. Rare interview with Leary's daughter Susan.

J73 Pahnke, Walter N., and William A. Richards. "Implications of LSD and Experimental Mysticism." J. Religion \& Health 5, no. 3 (July). Reprinted in J. Transpersonal Psychology 1, no. 2 (1969):93. Reference to the use of psychedelic therapy in the Concord Prison Project. 
J74 Kleps, Art. "Interview." Pageant Magazine (Aug.). Praise for Leary's "uncompromising and active role for the truth in psychedelics" by the leader of the Neo-American Church. Leary's statement on "LSD moratorium" appears on p. 63.

J75 Dallos, Robert E. "Dr. Leary Starts New 'Religion' with 'Sacramental' Use of LSD." New York Times (Sept. 20).

J76 "Celebration \# 1." New Yorker (Oct. 1): 42-43. Review of the initial "psychedelic celebration" produced by Leary in New York City.

J77 Gift, Joseph. "Dr. Leary . . . That Man from LSD: The High Priest of Hallucination." Uncensored, no. 5 (Oct.):24-25, 53-54. Scandal magazine expose on Leary and the Millbrook bust. Two photos.

J78 Masters, R. E. L. Critique of Leary's remarks in his Playboy interview (D1), published in the preceding month, on the value of LSD as an aphrodisiac, in: Bulletin of the Psychedelic Information Center, no. 16 (Oct.): pp. 3-4. Reprinted in Playboy (Nov. 1967), 223-24.

J79 "Straits Leery of Leary League." Berkeley Barb, no. 70 (Dec.):2. Coverage of Leary's San Francisco press conference, with photo of Leary and Allen Ginsberg at Playboy Club.

J80 Adams, Henry B. "A Case Utilizing Sensory Deprivation Procedures," in Case Studies in Behavior Modification, ed. L. P. Ullman and L. Krasner. (New York: Holt, Rinehart \& Winston), pp. 164-68. "The theoretical rationale and the multilevel measurements of personality developed by Leary $(1956,1957)$ and his associates at the Kaiser Foundation" are used in this case study.

J81 Alpert, Richard, Sidney Cohen, and Lawrence Schiller. lsd. (New York: NAL), pp. 12, 21, 26-27, 68, 72-73 passim. In this debate Alpert frequently quotes from the writing of his associate Leary, whom he terms "the most creative thinker in the psychedelic field."

J82 Bachrach, Arthur J., and William A. Quigley. "Direct Methods of Treatment," in An Introduction to Clinical Psychology, ed. I. A. Berg and L. A. Pennington. 3d ed. (New York: Ronald Press), p. 548. Reference to Leary, et al., "Reactions to Psilocybin" (AA45).

J83 Bergin, Allen E. "The Effects of Psychotherapy: Negative Results Revisited," in The Investigation of Psychotherapy, ed. A. P. Goldstein \& S. J. Dean. (New York: John Wiley \& Sons), p. 162. Author's research "confirms what was suggested in the Cartwright and Vogel and perhaps the Barron and Leary [AA13] study, that change does indeed occur in psychotherapy, but in opposite directions, the direction depending upon therapist qualities." 
J84 Cashman, John. The LSD Story. (Greenwich, Conn.: Fawcett), pp. 31-78 passim. Chapters 5 and 6, "Enter Timothy Leary, et al." and "Instant Zen," deal largely with Leary's involvement with psychedelic drugs between 1960 and 1966.

J85 Chance, Erika. "Content Analysis of Verbalization about Interpersonal Experience," in Methods of Research in. Psychotherapy, ed. L. A. Gottschalk and A. H. Auerbach. (New York: Appleton Century Crofts), pp. 132-34, and fig. 1. Discussion of Freedman, Leary, Ossorio and Coffey, 1951 (AA7), with figure representing an extension of the system designed by that group.

J86 Cutler, Richard L. "Countertransference Effects in Psychotherapy," in The Investigation of Psychotherapy, ed. A. P. Goldstein and S. J. Dean. (New York: John Wiley \& Sons), p. 265. "The personality traits on which the therapists and judges were asked to make ratings were derived from a device called 'The Circle' (Freedman, Leary, Ossorio, Coffey, 1951 [AA7])."

J87 Dana, Richard H. Foundations of Clinical Psychology. (Princeton, N.J.: Van Nostrand), pp. 136, 266-67. Reference to Interpersonal Check List and to Leary and Gill, 1959 (AA16).

J88 Di Prima, Diane. "The Holidays at Millbrook-1966." First published in Shaman Woman, Mainline Lady, ed. C. Palmer and M. Horowitz (New York: William Morrow, 1982), pp. 224-29. The poet lived in Leary's Millbrook commune and co-published Psychedelic Prayers (A5).

J89 Endicott, Noble A., and Jean Endicott. "Improvement in Untreated Psychiatric Patients," in The Investigation of Psychotherapy, ed. A. P. Goldstein and S. J. Dean. (New York: John Wiley \& Sons), p. 214. Barron and Leary's study (AA13) described as the only one of four studies on the testing of untreated psychiatric patients in which the patients "had been tested with the MMPI." Personal communication from Leary comments on the retesting of this group.

J90 Frank, Jerome D. "Problems of Controls in Psychotherapy as exemplified by the Psychotherapy Research Project of the Phipps Psychiatric Clinic," in The Investigation of Psychotherapy, ed. A. P. Goldstein \& S. J. Dean. (New York: John Wiley \& Sons), p. 81. "A sophisticated and promising example" is the scheme of interpersonal dimensions of personality devised by Leary and his co-workers.

J91 Goldstein, Arnold P. "Patient Expectancies and Nonspecific Therapy Therapy as a Basis for (Un)spontaneous Remission," in The Investigation of Psychotherapy, ed. A. P. Goldstein and S. J. Dean. (New York: 
John Wiley \& Sons), p. 204. "Support for Barron and Leary's conclusion [AA13] provided by preliminary results of an investigation by the present writer." Includes quotation from Barron and Leary.

J92 Goldstein, Richard. 1 in 7: Drugs on Campus. (New York: Walker), pp. 76-78. Student use of psychedelics at Harvard in the early 1960s.

J93 Heller, Kenneth, Roger A. Myers, and Linda Vikan Kline. "Interviewer Behavior as a Function of Standardized Client Roles," in The Investigation of Psychotherapy, ed. A. P. Goldstein \& S.J. Dean. (New York: John Wiley \& Sons), p.398. Authors agree with Leary's proposal "that each instance of interpersonal behavior tends to 'pull' or provoke specific counterresponses from the individual who is the target of the original behavior."

J94 Imber, Stanley D, et al. "Improvement and Amount of Therapeutic Contact," in The Investigation of Psychotherapy, ed. A. P. Goldstein and S. J. Dean. (New York: John Wiley \& Sons), p. 250. "The work of Rogers and his colleagues (1954) and Barron and Leary (1955) [AA13] "are exceptions to the generalization" [regarding] "the difference in results obtained from a no-treatment control group and an experimental (treatment) group."

J95 Lindgren, H. C., D. Byrne, and L. Petrinovich. Psychology: An Introduction to a Behavioral Science. (New York: John Wiley \& Sons), p. 366. "In his discussion of interpersonal factors in personality, Leary (1957) points out how people use various roles in a reciprocal way." Includes quotation from Interpersonal Diagnosis of Personality (A3).

J96 Lorr, Maurice, et al. "Frequency of Treatment and Change in Psychotherapy," in The Investigation of Psychotherapy, ed. A. J. Goldstein and S. J. Dean. (New York: John Wiley \& Sons), pp. 239-40. "The Interpersonal Checklist (ICL) (La Forge \& Suczek, 1955; Leary, 1957 [A3]) constitutes the source for the ICL criteria-assertiveness, cooperativeness, hostility, and dependence."

J97 Lorr, Maurice, and Douglas M. McNair. "Methods Relating to Evaluation of Psychotherapeutic Outcome," in Methods of Research in Psychotherapy, ed. L. A. Gottschalk and A. H. Auerbach. (New York: Appleton Century Crofts), pp. 578-80. Discussion of Leary's Interpersonal Behavior Circle.

J98 McNair, D. M., D. M. Callahan, and M. Lorr. "Therapist 'Type' and Patient Response to Psychotherapy," in The Investigation of Psychotherapy, ed. A. P. Goldstein and S. J. Dean. (New York: John Wiley \& Sons), p. 282. Refers to the use of Leary Interpersonal Check List in testing therapists' reactions to patients. 
J99 Phillips, J. S., et al. "Relationships between Descriptive Content and Interaction Behavior in Interviews," in The Investigation of Psychotherapy, ed. A. P. Goldstein and S. J. Dean, (New York: Wiley), p. 127. "The content aspects of the verbal interview behavior ... represents an adaption and extension of the Interpersonal System devised by Freedman, Leary, Ossorio, and Coffey (1951) [AA7]."

J100 Sanford, Nevitt. Self \& Society: Social Change \& Individual Development. (New York: Atherton), p. 89. "This way of thinking about levels has perhaps been developed most fully by Freedman, Leary, Ossorio, and Coffey (1951) [AA7]."

J101 Simmons, J. L., and Barry Winograd. It's Happening: A Portrait of the Youth Scene Today. (Santa Barbara, Calif.: Marc-Laird), p. 50. "Leary . . . has suggested five dilemmas which psychedelic journeys arouse."

J102 Snyder, William U. "Relationship and Client-centered Therapies," in An Introduction to Clinical Psychology, ed. I. A. Berg and L. A. Pennington. 3d ed. (New York: Ronald Press), p. 568. The author has developed a "circle" similar in conception to the Interpersonal Behavior Circle.

J103 Weinberg, Peter. "Tuesday Night at the Village Theatre." Inner Space, no. 3 (after Oct.). Review of Leary \& Company's three-part "psychedelic celebration" at New York's Village Theatre in Oct.

J104 Young, Warren R., and Joseph R. Hixson. LSD on Campus. (New York: Dell), pp. 54-73 passim. Chapter 4, "The Pied Piper of Harvard Town," deals with the psychedelic drug controversy at Harvard and subsequent events in Leary's life.

\section{7}

J105 “Love, Leary, LSD." LA Free Press (Jan. 13). Journalistic account of one of Leary's Psychedelic Celebrations, containing quotes from Leary's talk. Reprinted in The Hippie Papers, ed. Jerry Hopkins. (New York: NAL, 1968), pp. 82-87.

J106 Lerner, Max. "Are the Country's Youth in the Midst of a Passing Fad, Satanic Possession, or Genuine Exploration?" Mademoiselle (Jan.):52.

J107 Wilcock, John. "Human Be-In." International Times (London), no. 8 (Feb. 13-26):2. Leary spoke at a "Be-In" in San Francisco, attended by 20,000 .

J108 Krassner, Paul. "Lenny Bruce, Tim Leary and the Search for Alienation-Or Which Deodorant Does Lyndon Johnson Use?" The Realist, no. 73 (Feb.):1, 23-27. Bruce and Leary in the context of political satire. 
J109 Techter, David. "Psychedelics: The Beginning, Not the End." Fate, no. 2 (Feb.):50-51. Discusses The Psychedelic Experience (A4) as one of the few books that analyze the subject.

J110 Blinder, Elliot. "Millbrook's Chief Boo Hoo Speaks Out." Underground Digest, no. 2 (Mar.):61-65. Art Kleps discusses Leary in interview.

J111 Hinckle, Warren. "A Social History of the Hippies." Ramparts (Mar.). Section titled "Dr. Leary-Pretender to the Hippie Throne." Reprinted in: Gerald Howard (ed.), The Sixties. (New York, 1962), pp. 222-25.

J112 McDonagh, D. "Leary under the Glass." National Review (Apr. 4):360.

J113 "300 Back Formation of 'Anti-LSD' Group; Leary Calls Move 'Whipped Up Hysteria.'” Millbrook Round Table (May 18):1, 7. Townspeople move to drive Leary from Millbrook.

J114 Packard, Patricia H. "LSD: Magic Show for Madmen Only?" The Episcopalian, no. 8 (May):8-12. About Millbrook and the League for Spiritual Discovery.

J115 Trilling, Diana. "Celebrating with Dr. Leary." Encounter, no. 6 (June):36-46. Lengthy review of a Psychedelic Celebration in Greenwich Village. Reprinted in Contemporary Moral Issues, ed. H. H. Gervitz. 2d ed. (Belmont, Calif.: Wadsworth, 1968), pp. 532-47.

J116 Murray, Rev. George B., and Jean Houston. "LSD: The Inward Voyage." Jubilee, no. 2 (June):8-17. Leary mentioned on several pp.

J117 [Fairfield, Richard]. “A Straight Look at Millbrook." Modern Utopian, I, no. 6 (July-Aug.):35. Reprinted with additions in the author's Communes USA: A Personal Tour (Baltimore: Penguin, 1972).

J118 Bieberman, Lisa. "The Psychedelic Experience." New Republic (Aug. 5):17-19. Why Leary and other "publicized advocates of the psychedelic are its worst enemies." A slightly different version appeared in the author's Psychedelic Information Center Bulletin, no. 12 (June 1967).

J119 Flagler, J. M. "The Visions of 'Saint Tim.'” Look (Aug. 8):18-21. Visit with Leary at Millbrook. Thirteen color photographs of the Psychedelic Celebration based on Hesse's Steppenwolf, performed at Millbrook.

J120 Ginsberg, Allen. "Journal Entry on Visit to Timothy Leary's House in Boston, Dec. 1960." Klacto/23 special number [Klactoveedsedsteen] no. 5 (Sept.): 43-44. Cited in Dowden, Bibliography of Allen Ginsberg, p. 79. LSD-inspired poem. 
J121 Weinberg, Peter. "On This Cube I Will Build My Church." East Village Other (Oct. 1-15):5. Description of press conference held in New York City at which Leary announced the formation of the League of Spiritual Discovery.

J122 "Giants." Esquire (Oct.):138. Four famous people, including Leary, who were at one time West Point cadets,

J123 Phelan, James. "High Priest of the Happy Hippies." True, no. 366 (Nov.):31-33, 84-88. Description of Millbrook and a Leary-directed "celebration" in New York City.

J124 Helleberg, Marilyn Morgan. "The LSD Experience and Religious Mysticism: An Objective Comparison." Ante, no. 3 (Fall):29. Questions Leary's statement that drugs may be the only way an American can have a religious experience.

J125 Benson, J. Kenneth, and James Otis Smith. "The Harvard Drug Controversy: A Case Study of Subject Manipulation and Social Structure," in Ethics, Politics, and Social Research, ed. G. Sojberg. (Cambridge, Mass.: Schenkman), pp. 115-40. A well-researched case study, containing sixty-six citations to printed source materials.

J126 Braden, William. The Private Sea: LSD and the Search for God. (Chicago: Quadrangle Books), pp. 68, 104, 118, 213. Many references to Leary focus on his ideas and writings on the religious context of psychedelic drugs.

J127 Bradley, and Eglinton. Rex Morgan, M.D. Syndicated comic strip. A doctor who opens his mansion to college students and provides LSD for their enlightenment is modelled after Leary at Millbrook.

J128 Bronsteen, Ruth. The Hippy's Handbook. (New York: Canyon Book Co.), p. 31. In "Who's Who of the Underground," Leary is described as a "hippy Pope" and founder of the League of Spiritual Discovery.

J129 Brown, Joe David (ed.). The Hippies. (New York: Time), pp. 114-15. Two photographs of Leary visiting League for Spiritual Discovery headquarters in New York.

J130 Chayet, Neil L. "Social and Legal Aspects of LSD Usage," in LSD, Man \& Society, ed. R. C. DeBold and R. C. Leaf. (Middletown, Conn.: Wesleyan University Press), pp. 101-8. Compares the use of psychedelic drugs as religious sacraments by the Native American Church and Leary's League for Spiritual Discovery.

J131 Chevallier, James. "Castalia." Ovum, no. 2: 19-26. Local literary magazine editor visits Millbrook commune; tour conducted by Leary's son Jack. 
J131a Cohen, Sidney. The Beyond Within: The LSD Story. 2nd ed., with two additional chapters. (New York: Atheneum), pp. 223-24, 251-54 passim. A critique of the activities of the "chemical Pied Piper," with a 12-point refutation of ideas expressed by Leary in his Playboy interview (AA47).

J132 Harris, Thomas A. I'm OK-You're OK. A Practical Guide to Transactional Analysis. (New York: Harper \& Row), pp. 13-15. Excerpts from Leary's address delivered at Dewitt State Hospital, Calif., Feb. 23,1960 , with author's commentary. This is the first and only publication in book form of any part of this talk.

J133 Itkin, Rev. Michael Francis. "From an Open Letter to Timothy Leary." Innerspace, no. 4:25. Questions Leary's advocacy of drugs DMT and DET.

J134 Kleps, Art. The Neo-American Church Catechism and Handbook. (Millbrook, N.Y.: The Kriya Press of the Sri Ram Ashram). Many references to Leary, with whom the author was closely associated at the Castalia Foundation, Millbrook, 1964-66.

J135 Laurie, Peter. Drugs: Medical, Psychological and Social Facts. (Baltimore: Penguin Books), pp. 124-27. Discussion of the Leary-Alpert-Metzner Psychedelic Experience text (A4), with quotation.

J136 Leech, Kenneth, and Barbara Jordan. Drugs for Young People: Their Use and Abuse. (Oxford: The Religious Education Press), p. 37. Quotes The Psychedelic Experience (A4) on the meaning of the term psychedelic.

J137 Mathers, Ann C. The Hip Pocket Book. Illustrated by Dian Humphrey. (New York: Privately Printed), p. 36. Leary prediction reprinted from City of San Francisco Oracle.

J138 Meers, M., and C. Neuringer. "A Validation of Self-Concept Measures of the Leary Interpersonal Check List." J. Gen. Psychology 77:237-42.

J138a Sann, Paul. Fads, Follies and Delusions of the American People. (New York: Crown), pp. 241-44. Chapter entitled "Timothy Leary: A Religion Called LSD," with four photos.

J139 Shostrum, Everett L. Man, the Manipulator. (Nashville: Abingdon Press), p. 207 and figure 1. Figure 1 (p.37) is a full-page simplified version, with cartoon figures, of Leary's Interpersonal Behavior Circle.

J140 Stafford, Peter, and Holly Golightly. LSD-the Problem-Solving Psychedelic. (New York: Tandem Books). Many references and occasional quotation from various of Leary's '60s activities. A later edition 
of this book (New York: College Notes \& Texts, 1971) contains a cover illustration portraying Leary and other ' 60 s figures in the guise of Christ and the Apostles after Leonardo da Vinci's The Last Supper.

J141 Truax, Charles B., and Robert R. Carkhuff. Toward Effective Counseling and Psychotherapy. (Chicago: Aldine), p. 7. "The Barron and Leary study [AA13] is of particular importance, since it is one of the few studies utilizing fully qualified therapists."

\section{8}

J142 Kogen, Arnie. "A Celebrity's Wallet." Mad, no. 116 (Jan.):2 unnumbered pp. Satire of Leary and LSD, consisting of ten imaginary letters and documents that might be found in Leary's wallet.

J143 Slack, Charles. "An Evening with Tim Leary." Eye (March). Earlier form of Chapter 2 of Slack's Timothy Leary, the Madness of the Sixties and $\mathrm{Me}$ ( $\mathrm{J} 335)$.

J144 Mad Magazine, no. 118 (Apr.). Psychedelic-style cover satirizes Leary slogan (Turn On, Tune In, Drop Dead).

J145 "Clean Genes." Berkeley Barb (May 31-June 6):1, 13. Leary reveals medical report showing he has no chromosome damage despite repeated LSD use.

J146 Toback, James. "Whatever You'd Like Susan Sontag to Think, She Doesn't." Esquire (July):114-15. Sontag accuses Leary of "blatant exploitation and intellectual sham."

J147 Sanford, D. "Travels with Leary." New Republic (Oct. 26):32-34.

J148 Cecil, Kathy. "And This God's Name is Abraxis." The Scholastic (Nov. 15):20-21. Leary's religious approach to drugs and the importance of confronting the Unknown inside.

J149 Ginsberg, Allen. Article on Leary. Village Voice (Nov.). Beat poet places Leary in the tradition of American "heroes of consciousness." Reprinted as the first section of Ginsberg's Preface to Jail Notes (A12).

J150 Barnes, Carolyn (ed.). The Hippie Scene. (New York: Scholastic Book Services), pp. 22, 43. Importance to hippies of the Turn On, Tune In, Drop Out slogan and The Psychedelic Experience (A4).

J151 Caldwell, W. V. LSD Psychotherapy: An Exploration of Psychedelic and Psycholytic Therapy. (New York: Grove Press), pp. 23-35 passim. Chapter 2 of this book, "Another Reality," is entirely devoted to an analysis of Leary and Richard Alpert's role in connection with psychedelic drugs. 
J152 Carey, James T. The College Drug Scene. (Englewood Cliffs, N.J.: Prentice-Hall), p. 38. Refers to the "Leary Lobby" and the Harvard research on psychedelics.

J153 Clark, Walter Houston. "Religious Aspects of Psychedelic Drugs." California Law Review: 93-94. Refers to the psilocybin experiment at Concord Prison in 1962.

J154 Earisman, Delbert L. Hippies in Our Midst: The Rebellion beyond Rebellion. (Philadelphia: Fortress Press), pp. 82-83, 118. Leary's responsibility for the hippie subculture.

J155 Friday, Bill. I Love You, Alice B. Toklas! (New York: Bantam Books), pp. 164-66. Novelization of the film of the same title starring Peter Sellers and Leigh Taylor-Young. In both book and film (see L33), The Psychedelic Experience (A4) is used as a guidebook for an LSD trip.

J156 Guthrie, Robert V. (ed.). Psychology in the World Today. (Reading, Mass.: Addison-Wesley) pp. 233-34. Discusses Leary's "psychic revolution," with quotation from "The Politics of Consciousness Expansion" (AA42).

J157 Heller, Kenneth. "Ambiguity in the Interview Interaction." Research in Psychotherapy. Proceedings of the $3 d$ Conference, 1966. (Washington: American Psychological Assoc.), p. 245. "We . . . chose to expand the scope of client behaviors studied to include both affect and control behaviors proposed by Leary (1957) [A3] and others . . . as major dimensions accounting for much variance in interpersonal behavior."

J158 Hoffman, Nicholas von. We Are the People Our Parents Warned Us Against. (Chicago: Quadrangle Books), p. 106-7 passim. Hippies discuss Leary.

J159 Huxley, Laura Archera. This Timeless Moment: A Personal View of Aldous Huxley. (New York: Farrar, Straus \& Giroux), p. 298. During the last weeks of Aldous Huxley's life, he and his wife "read the entire manual [A4] of Dr. Leary based on the Tibetan Book of the Dead."

J160 Kleps, Art. History of the Psychedelic Movement Cartoon \& Coloring Book. (Millbrook, N.Y.: The Neo-American Church), pp. [9, 10, 21, 41]. Some of the full-page cartoons humorously refer to events in Leary's life, others to his colleagues. See B13 for fuller description of this work.

J161 Klopfer, Walter G. "Current Status of the Rorschach," in Advances in Psychological Assessment, ed. Paul McReynolds. (Palo Alto, Calif.: Science \& Behavior Books), vol. I, p. 140. Discussion of the Interpersonal Check List. 
J162 Larner, Jeremy. The Answer. (New York: Macmillan). A novel in which one of the major characters, Dr. Magus Tyrtan, is loosely based on Leary. The setting, Heavenly House, is similar to Millbrook, and a drug similar to LSD is called the Answer Drug.

J162a Nin, Anaïs. The Novel of the Future. (New York: Macmillan), pp. 95-96, 113. The diarist and novelist recounts her discussions with Leary about LSD and creativity.

J163 Nuttall, Jeff. Bomb Culture. (New York: Delacorte Press), pp. 209-12 passim. The text of the flier for the Castalia Foundation's Experiential Workshops (1965-66) is reproduced in its entirety, and credited to Leary, Alpert and Metzner.

J164 Oursler, Will. Religion: Out Or Way Out? (Harrisburg: Stackpole Books), pp. 41-42, 118. Description of a "psychedelic celebration" led by Leary in New York's East Village.

J165 Poland, Jefferson F. and Sam Sloan (eds.). Sex Marchers. (Los Angeles: Elysium). Poland, founder of the Sexual Freedom Movement, criticizes Leary's opposition to group marriage.

J166 Regardie, Israel. Roll Away the Stone. (St. Paul, Minn.: Llewellyn), pp. 20, 38-40, 54-55, 58, 64-65. Extensive quotation from Leary's introduction to LSD: The Consciousness-Expanding Drug (B4), "How to Change Behavior" (AA23) and the Playboy interview (AA47).

J167 Sagehorn, Robert E. "LSD: Leary and the Acid Surrogate," in The Smith/8, ed. Harry Smith. (New York: Horizon Press), pp. 178-79. "What is not yet clear is to what extent drugs will replace alcohol."

J168 Weiss, Robert L. "Operant Conditioning Techniques in Psychological Assessment," in Advances in Psychological Assessment, ed. P. McReynolds. (Palo Alto, Calif.: Science \& Behavior Books), vol. I, p. 173. Discussion of the Interpersonal Check List.

J169 West, Louis, and James Allen. "Three Rebellions: Red, Black and Green," in The Dynamics of Dissent, ed. J. H. Masserman. (New York: Grune \& Stratton), pp. 99-119. Following a discussion of the meaning of the slogan Turn On, Tune In, Drop Out, the authors suggest that Leary was unjustly blamed for merely using "the new slang to describe what was already happening."

J170 Winter, William D., and Antonio J. Ferreira. (eds.). Research in Family Interaction. (Palo Alto, Calif.: Science and Behavior Books), p. 308. Refers to the Interpersonal Check List.

J171 Wolfe, Burton H. The Hippies. (New York: New American Library), pp. 23-24, 145-47 passim. About Leary's importance to the counterculture. 
J172 Kohn, Jaakov. "In the Beginning: An Interview with Gunther Weil." East Village Other (Feb. 21): 8, 19. Weil, a colleague of Leary and Richard Alpert at Harvard, recalls their experiences during the early 1960s.

J173 Grossman, David. "Changes." Berkeley Barb, (Feb. 28-Mar. 6):7. Review of Leary's five lectures on hedonic psychology presented at the Free University of Berkeley.

J174 Saint Phalle, Anne de. "An Exploration of LSD, Richard Alpert, and Higher Forms of Consciousness." The Crimson Supplement (Apr. 23):3-7, 10-16. An in-depth profile of Richard Alpert after his return from India, with much on Leary.

J175 UPI. "LSD High Priest's Case Overturned. High Court Clears Leary on Marijuana." Los Angeles Times (May 20):1. Headline story: the Supreme Court overturned Leary's federal marijuana conviction, upholding his claim that by registering and paying tax, he would have been incriminating himself.

J176 Aldrich, Michael. "High Court Frees High Priest." East Village Other (June 25):5, 17. An analysis of the consequences of the U.S. Supreme Court decision overturning Leary's marijuana conviction.

J177 Ashford, Harold A., and Michael D. Risinger. "Presumptions, Assumptions, and Due Process in Criminal Cases: A Theoretical Overview." Yale Law J. 79, no. 2 (Dec.):205-8. Section VIII, “A Note on Leary v. U.S.," deals with the decision of the U.S. Supreme Court to overthrow Leary's conviction.

J178 Blewett, Duncan. The Frontiers of Being. (New York: Award/Tandem), pp. 96, 248, 263. Reference is made to Leary's ideas as expressed in The Psychedelic Experience (A4).

J179 Carson, Robert C. Interaction Concepts of Personality. (Chicago: Aldine), pp. 103-16, passim. Credits the Kaiser Foundation group with "the initial suggestions that interpersonal behavior may be circumplicially ordered." Reproduces the Interpersonal Behavior Circle (fig. 4.1), "our foremost means of coding interpersonal behavior."

J180 Clark, Walter Houston. Chemical Ecstasy: Psychedelic Drugs and Religion. (New York: Sheed \& Ward), pp. 46-62, passim. Chapter 4, "Historical Notes: The Harvard Incident," deals largely with the history of the psychedelic drug controversy at Harvard.

J181 Edwards, Ethel. Psychedelics and Inner Space. (Cincinnati: Psyche Press), pp. 2-4. About Leary's contribution to the "psychedelic revolution." 
J182 Geller, Allen, and Maxwell Boas. The Drug Beat. (New York: Cowles), pp. 161-72 passim. Chapter 12 is entirely devoted to activities of Leary and Richard Alpert during the ' $60 \mathrm{~s}$.

J183 Goode, Erich (ed.). Marijuana. (Chicago: Aldine-Atherton), p. 174. Leary's idea of imprinting under the influence of psychedelic drugs.

J183a Horn, Richard. Encyclopedia. (New York: Grove), p. 61. Discussion of the importance of a character in this novel wearing a "Hands Off Tim Leary" slogan button in 1966.

J184 Huxley, Aldous. Letters. Ed. Grover Smith. (New York: Harper \& Row), pp. 909, 928-29, 944-45, 953-55. Included are four letters to Leary written between 1961 and 1963 (reprinted in Moksha, B32), while Huxley's letters to several others contain references to Leary.

J185 Klapp, Orrin E. Collective Search for Identity. (New York: Holt, Rinehart \& Winston), pp. 171-73. Leary and the psychedelic movement.

J186 Kramer, Jane. Allen Ginsberg in America. (New York: Random House), pp. 5-6, 34, 187-88. Ginsberg describes several encounters with Leary during the 1960s, including their experiences giving LSD to creative artists.

J187 Nolan, Tom. "Leary in Limbo." US, no. 2:165-85. Account of a day spent with Leary in Tucson, with much quotation.

J188 Robinson, John P., and Philip R. Shaver. Measures of Social Psychological Attitudes (Ann Arbor, Mich.: Survey Research Center), pp. 135-39 passim. A detailed analysis of Leary's Interpersonal Behavior Circle, which is reproduced.

J189 Roszak, Theodore. The Making of a Counter Culture. (Garden City, N.Y.: Doubleday), pp. 155-77. Chapter 5, "The Counterfeit Infinity," contains discussion of Leary's negative influence on the religious values of the counterculture.

J190 Stearn, Jess. The Seekers. (New York: Doubleday), pp. 354-62 passim. Stearn describes his conversations with Leary, whom he confronted on the drug issue, at Millbrook during the mid-1960s.

J191 Tart, Charles. Altered States of Consciousness. (New York: John Wiley \& Sons), pp. 37, 302, 422, 480-81. Refers to The Psychedelic Experience (A4) and three articles by Leary; compares him to Henri Michaux.

J191a Voelcker, Hunce. Songs for the Revolution. (New York: Cowstone Press). In the poem "Revolution" there is a stanza about Leary running for governor of California. 
J192 Wolfe, Tom. The Electric Kool-Aid Acid Test. (New York: Farrar, Straus \& Giroux). Chapter 9 is about the meeting between Leary and the "Merry Pranksters" (Ken Kesey et al.) at Millbrook in 1966.

\section{0}

J193 Alpert, Richard, et al. "The Drug Revolution." Playboy (Feb.): 53-74, 200-201. Leary's name comes up frequently in this panel discussion among Richard Alpert, Harry Anslinger, William Burroughs, James Coburn, Leslie Fiedler, Alan Watts and others.

J194 Hayes, Bob. "Holding Together." Berkeley Barb (Mar. 6-12): 7, 15. The formation of Holding Together, a defense organization to help the imprisoned Leary.

J195 Albert, Stew. "Leary, Jail, and Bad Vibes." Berkeley Barb (Mar. 6-12): 3. About Leary held in Orange County jail awaiting sentencing for marijuana possession.

J196 “Tim, Jack, Rosemary Sentenced." Berkeley Barb (Mar. 20-26): 3. The sentencing of Leary to six months to ten years for possession of two marijuana roaches, and probation for his wife and son.

J197 Filippo, Chet. "Ten Years in Texas for Tim Leary." Rolling Stone (Apr. 2): 26, 28. The sentencing of Leary in Laredo to ten years' imprisonment for possession of half an ounce of marijuana.

J198 Announcement of the Formation of Holding Together. Berkeley Barb (Apr. 3-9). A defense organization formed for Timothy and Rosemary Leary after he was sentenced to prison in Mar. 1970.

J199 Ogar, Richard. "Holding Together with Leary." Berkeley Barb (Apr. 10-16): 1. Description of Holding Together benefit ("Om Orgy") for Leary.

J200 Schoenfeld, Eugene, M.D. "Dr. Hip Raps on Dr. Tim." Berkeley Barb (May 1-7): 2, 13. "Tim and Rosemary and Jack are victims of the scapegoat theory, of the notion that ideas can be silenced by prisons."

J201 Osmond, Humphry. "Holding Together." Crawdaddy (May): 16. The psychiatrist who coined the term psychedelic analyzes the political implications of Leary's imprisonment.

J202 Koestler, Arthur. "A Conversation." Psychology Today (June): 63-65, $78,82,84$. In speaking of his LSD experiences, the novelist remarks, "No matter what my old friend Tim Leary says, artificial paradises are dangerous." 
J203 "Proud Eagle Flies Free." East Village Other (Sept. 15): 1. Headline about Leary's prison escape on Sept. 12.

J204 Dohrn, Bernadine. "Communique \#4 from the Weatherman Underground." San Francisco Good Times (Sept. 18). The Weatherman Underground takes credit for Leary's prison escape.

J205 Laurence, Leo. "Leary Gets It On—Lawỷers Jubilant." Berkeley Barb (Sept. 18-24) 2-3. Prints Leary's "escape lètter" and the communiqué of the Weather Underground. Lawyer Michael Kennedy is interviewed.

J206 Manson, Charles. "An Open Letter to Tim Leary." Los Angeles Free Press (Oct. 9): 1. The imprisoned Manson's reactions to news of Leary's new revolutionary politics.

J207 “Tim's Freee in Algereee!!!" Berkeley Barb (Oct. 16-22): 2. Announcing Timothy and Rosemary Leary's arrival in Algiers, after his escape from prison and their flight from the United States.

J208 Albert, Stew. "Look Amerika [sic] What You've Made of the Prince of Peace." East Village Other (Oct. 20): 3. Report of a visit with the Learys and Eldridge Cleaver in exile in Algeria.

J209 Siegel, Ronald. "Experiencing Mr. Leary." UCLA Daily Bruin (Nov. 2): 7, 10. Review of High Priest (A7).

J210 Kesey, Ken. "An Open Letter to Timothy Leary from Ken Kesey." Rolling Stone (Nov. 12): 31. Letter from the novelist and Merry Prankster congratulating Leary on his escape but disagreeing with his call for armed violence.

J211 Taylor, Robert. "The Young Manhood of Timothy Leary." Boston Sunday Globe (Nov. 29). Biographical sketch of Leary's life from childhood through graduate school, with unpublished data and photographs.

J212 Lester, Julius. “Aquarian Notebook." Liberation, no. 9 (Nov.): 36-37. Author reflects on Leary's conversion to radical politics upon escaping from prison and joining Eldridge Cleaver in exile in Algeria.

J213 "Distinguished Dropouts." Parade (Dec. 6). Signed "L.S." About famous West Point dropouts, with Leary described as "surely the most controversial . . . of all time."

J214 Aaronson, Bernard, and Humphry Osmond (eds.). "Introduction." Psychedelics: The Uses and Implications of Hallucinogenic Drugs. (Garden City: Doubleday). Numerous references to Leary in their general and sectional introductions. 
J215 Aldrich, Michael R. Untitled chapter in Drugs: For \& Against, ed. H. Hart (New York: Hart): 80, 81. Refers to idea of Leary and others to establish "psychedelic centers," and to his imprisonment.

J216 Bales, Robert Freed. Personality \& Interpersonal Behavior. (New York: Holt, Rinehart \& Winston), p. 52. Reference to the Interpersonal Check List.

J217 Barber, Theodore X. LSD, Marijuana, Yoga, and Hypnosis. (Chicago: Aldine), pp. 57, 63 passim. Refers to Leary's psilocybin-assisted therapy with prisoners.

J218 Brill, Henry. "Pro-Drug Dialectic Communication in Drug Abuse and the Marijuana Red Herring." Communication and Drug Abuse: Proceedings of the Second Rutgers Symposium on Drug Abuse, ed. by J. Wittenborn, J. Smith and S. Wittenborn. (Springfield,Ill.: Thomas), pp. 27-28. Discussion of Leary's position as "a leader for the pro-drug movement that emerged in 1960."

J218a Buros, Oscar K. Personality: Tests and Reviews. (Highland Park, NJ: Gryphon Press), nos. 127, 446 (section 1) and 223 (section 6). Description of Interpersonal Check List and Interpersonal Fantasy Test manual with over 100 references; lengthy reviews of the ICL and Interpersonal Diagnosis of Personality (A3) by Jerry S. Wiggins.

J219 Cassens, James. The Christian Encounters Drugs and Drug Abuse. (St. Louis: Concordia), pp. 30-32 passim. Section "Enter Timothy Leary" summarizes Leary's involvement with psychedelic drugs.

J220 Clark, Jonathan. "The Use of Psilocybin in a Prison Setting," in Psychedelics, ed. B. Aaronson and H. Osmond. (Garden City: Doubleday), p. 40. Description by one of Leary's co-workers of the Concord Prison Project.

J221 Clark, Walter Houston. "The Psychedelics and Religion," in Psychedelics, ed. by B. Aaronson and H. Osmond. (Garden City: Doubleday), pp. 186-87. Describes evidence of religious experience via psychedelic drugs in Leary's experiment with prisoners.

J222 [Cohan, Tony]. The Dealer (No. Hollywood: Brandon House), 57, 95-97. A scene in this erotic satirical novel is set in the Berkeley Hills home of Timothy and Rosebaby Bleary. Written under the pseudonym "Malcolm Spade."

J223 Eysenck, Hans J. "The Effects of Psychotherapy," in Social Psychology through Symbolic Interaction, ed. G. T. Stone \& H. A. Farberman. (Waltham, Mass.: Ginn-Blaisdell), pp. 731-33. Analysis of the 
Barron-Leary study (AA13) originally published in H. Eysenck's Handbook of Abnormal Psychology (1961).

J224 Feigelson, Naomi. The Underground Revolution: Hippies, Yippies, and Others. (New York: Funk \& Wagnalls), pp. 35-39 passim. Leary's role with the "dropped-out generation."

J225 Fieldler, Leslie. "The Cultural Revolution' and its. Brophets." Anonym $5 / 6: 1-8$. Leary is viewed as "one of the first prophets of a religion based on technology" and part of a line of "cultural prophets" in America, from D.H. Lawrence and Wilhelm Reich to Buckminster Fuller, Marshall McLuhan, Norman Brown and Norman Mailer.

J226 Fort, Joel. The Pleasure Seekers: The Drug Crises, Youth and Society. (New York: Grove), p. 93. Refers to the upcoming Supreme Court ruling on Leary's marijuana conviction appeal.

J227 Goode, Erich. The Marijuana Smokers. (New York: Basic Books), p. 265. Refers to the implications of the Supreme Court decision in Leary v. U.S.

J228 Harrington, Alan. The Immortalist. (New York: Avon Books), pp. 40, 144, 177, 228. (1st ed.: New York: Random House, 1969.) Refers to Leary as "the prophet of psychedelic revelation" and quotes briefly from his work in several contexts.

J229 Louria, Donald B. The Drug Scene. (New York: Bantam Books), pp. 131-2 passim. (1st ed.: New York: McGraw Hill, 1968.) Author refers to his "multiple debates" with Leary.

J230 Luft, Joseph. Group Processes. 2nd ed. (Palo Alto, Calif.: National Press Books), pp. 51-54. (1st ed.: 1963.) Discussion of the "circumplex model" of interpersonal behavior, with reproduction of two versions of the Interpersonal Behavior Circle (figs. 20-21).

J231 Meltzoff, Julian and Melvin Kornreich. Research in Psychotherapy. (New York: Atherton Press). Many references to Leary.

J232 Metzner, Ralph. "Mushrooms and the Mind," in Psychedelics, ed. B. Aaronson \& H. Osmond. (Garden City: Doubleday), p. 105. Quotation from Leary's "The Religious Experience" (AA43).

\section{1}

J233 Dohrn, Jennifer. Interview. San Francisco Good Times (Jan. 8): 5-7. Description of visit with the Learys in Algeria by the sister of the Weather Underground leader. 


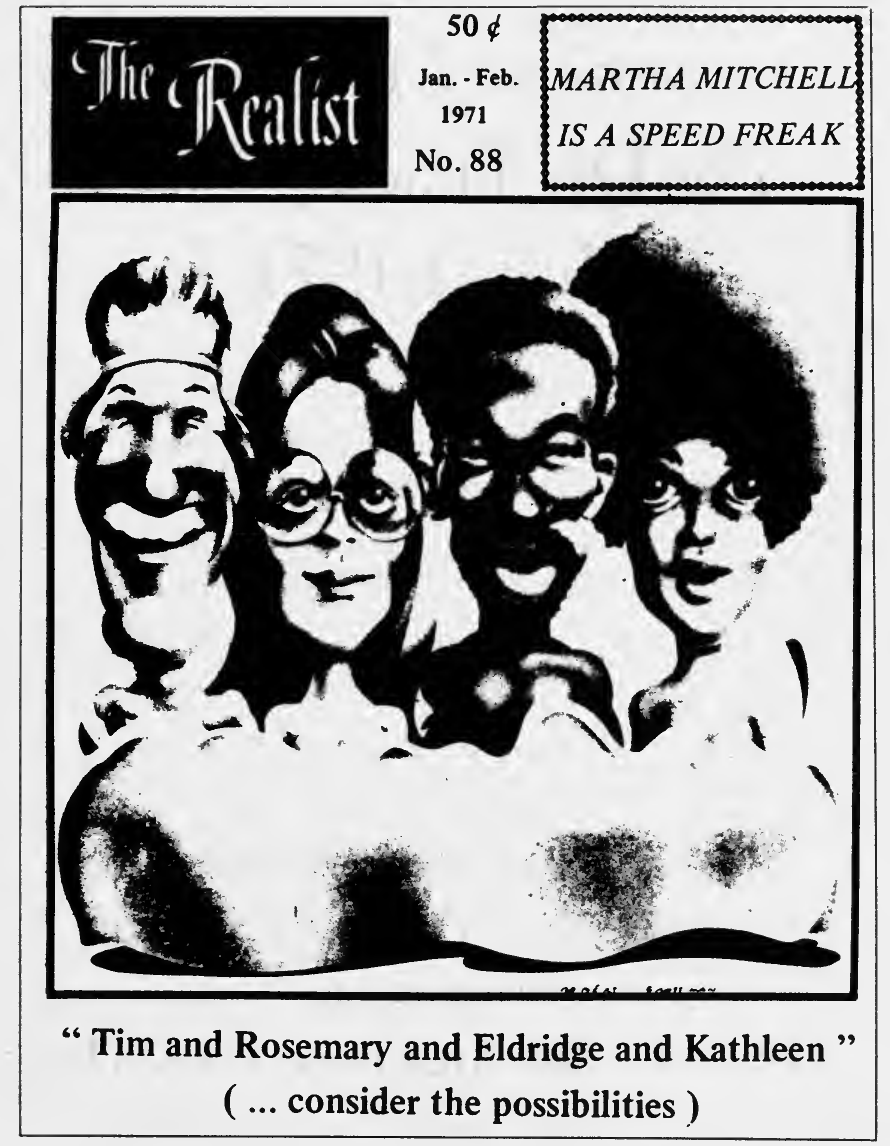

J235: Satirical view of the Learys and Cleavers in exile. Courtesy Paul Krassner.

J234 Zwerin, Michael. "Outside: Algiers/ A Revolutionary Bust." Village Voice (Jan. 29-Feb. 4): 28, 30, 32-34, 36. Taped discussion with Leary and Cleaver, regarding the former's imprisonment by the latter.

J235 Raskin, Jomo. "Report from Algiers." The Realist, no. 88 (Jan.-Feb.): 4-5. Analysis of the alliance between Leary and the Black Panther party in exile. Cover has a Robert Grossman drawing of the Learys and Cleavers in bed together, captioned " "Tim and Rosemary and Eldridge and Kathleen' ( . . . consider the possibilities)."

J236 Cleaver, Eldridge. "Cleaver's Pronouncement." Berkeley Barb (Feb. 5-11): 3, 11. Transcipt of tape by Cleaver explaining his confinement of Timothy and Rosemary Leary. 


\section{Declaration of Independence}

For Dr. Timothy Leary July 4, 1971

\section{Model Statement in Defense of the} Philosophers Personal Freedom Proposed by

\section{San Francisco Bay Area Prose Poets' Phalanx}

J238: Allen Ginsberg's defense of the imprisoned Leary.

J237 Zwerin, Michael. "Algerian Acid Cap-Tives. Free Tim, Again. Free All Political Prisoners!” Berkeley Barb (Feb. 5-11): 1-2, 10-11. (Reprinted from Village Voice). Report on Cleaver's confinement of the Learys.

J237a Vonnegut, Kurt, Jr. Rags (Mar.), p. 25. "I haven't seen anyone my age do much with the clothing thing except Timothy Leary maybe, or Allen Ginsberg.

J238 Ginsberg, Allen. Declaraton of Independence for Dr. Timothy Leary, July 4, 1971. (San Francisco: Hermes Free Press). "Model Statement in Defense of the Philosophers Personal Freedom Proposed by San Francisco Bay Area Prose Poets' Phalanx." Leaflet written anonymously by 
Ginsberg and signed by poets, essayists and novelists. Widely reprinted in the underground press.

J239 Bess, Donovan. "Writers Petition Swiss to Give Asylum to Leary." San Francisco Chronicle (July 14): 3 . The first report in the print media of this event. Among the writers were Allen Ginsberg, Anaïs Nin, Alan Watts, Ken Kesey, Laura Huxley and members of the American Center of P.E.N.

J240 "Leary in Swiss Dungeon." Berkeley Barb (July 23-29): 5, 10. Report on Leary's imprisonment in Lausanne.

J241 Pearce, Donn. "Leary in Limbo." Playboy (July): 124-26, 160-68. Pearce talks with Tim and Rosemary Leary in Algeria.

J242 Leary, Rosemary. "Lausanne." Marijuana Review, no. 7 (July-Sept.): 6. Letter from Switzerland, requesting help for her husband's imprisonment.

J243 Ferrera, Sal. "The Latest on Leary. Free Again . . . For the Time Being." Los Angeles Free Press (Aug. 29): 9. Report on Leary's release from Swiss prison.

J244 [Horowitz, Michael]. "Historic Meeting . . Tim and Dr. LSD." Berkeley Barb (Sept. 24-30): 8. On the first meeting between Leary and Albert Hofmann, discoverer of LSD. Written under the pseudonym Fitz Hugh Ludlow.

J245 Alpert, Richard (Ram Dass). Be Here Now. (San Cristobal, N.M.: Lama Foundation), pp. [2-14]. Detailed discussion of the author's relationship to Leary, the Psychedelic Research Program at Harvard, and subsequent activities together during 1960-67.

J246 "Rock 'n Roll/ Long-Haired/ Dope Yoga. Confessions of a 25-year-old All American Dope Eater," in Toward Social Change, ed. R. Buckhourt. (New York: Harper \& Row), p. 301. Description of talk given by Leary at a college in Stockton, Calif. in the mid-1960s.

J247 Byrne, Donn. The Attraction Paradigm. (New York: Academic Press), p. 184. Brief analysis and experimental use of the Interpersonal Check List.

J248 Clayton, George. Sex \& Drugs. (New York: Macfadden Bartell), pp. 65,99 . Contains a two-paragraph quotation alleged to be unpublished material from Leary's Harvard Psilocybin Project on the sexual aspects of LSD and psilocybin. The cover of the paperback cites the author as "Clayton Matthews."

J249 Cohen, Allan Y. "Acid and the Search for God." Earwig (Auckland, N.Z.) 5: 16-18. Author took a clinical psychology course with Leary 
and Richard Alpert at Harvard in 1961, later lived at Millbrook, and critiques them here.

J250 Cook, Bruce. The Beat Generation. (New York: Scribners), pp. 187-96 passim. On Leary's relationships with Beat Generation writers.

J251 Corbett, J. Elliott. Turned On by God. (Richmond: John Knox Press), pp. 72, 74, 79, 82-83. Critique of Leary's ideas about the religious aspects of LSD.

J252 Davis, John D. The Interview as Arena: Strategies in Standardized Interviews and Psychotherapy. (Stanford, Calif.: Stanford University Press), pp. 123-24. Alludes to recent study that rated subjects subjects on Leary's rating scale (1957; A3) and the Interpersonal Behavior Circle.

J253 Fredenburgh, Franz A. The Psychology of Personality Adjustment. (Menlo Park, Calif.: Cummings), pp. 91, 287. Author presents "The Timothy Leary Story," an account of Leary's work in the 1950s and his prison escape and Algerian exile. Compares the "discrediting" of Leary to that of Franz Anton Mesmer.

J254 Goldberg, Lewis R. "A Historical Survey of Personality Scales and Inventories," in Advances in Psychological Assessment, ed. P. McReynolds. (Palo Alto: Science \& Behavior Books), vol. II, p. 323. Discussion of the Interpersonal Check List.

J255 Grinspoon, Lester. Marihuana Reconsidered. (New York: Bantam Books), p. 81. (1st ed.: Cambridge: Harvard University Press, 1971.) Compares Baudelaire and Leary on the subject of "set and setting."

J256 Klinger, Eric. Structure and Functions of Fantasy. (New York: Wiley-Interscience), p. 326. Discussion of Leary's "Theory and Methodology for Measuring Fantasy and Imaginative Expression" (AA15).

J257 Krassner, Paul. How a Satirical Editor Became a Yippie Conspirator in Ten Easy Years. (New York: Putnam), pp. 98-104. Chapter entitled "Dr. Strangeleary" describes the author's trip to Millbrook in 1964 to attend a seminar given by the Castalia Foundation.

J258 Malcolm, Andrew I. The Pursuit of Intoxication. (New York: Washington Square Press), pp. 242-43 passim. Discussion of Leary's ideas concerning LSD and re-imprinting.

J259 Mischel, Walter. Introduction to Personality. (New York: Holt, Rinehart \& Winston). "Probably the most dramatic and controversial manifestation of this trend to achieve deeper feeling . . . in the efforts to 
expand consciousness and emotional experiences by means of psychedelic drugs [was] advocated most energetically by Timothy Leary."

J260 Neville, Richard. Playpower. (London: Paladin), pp. 115-16, 126-28 passim. On the handling of Leary and his image by the underground press.

J261 Reisner, Robert. Graffiti: Two Thousand Years of Wall Writing. (New York: Cowles), pp. 128-29. Lists five items of graffiti pertaining to Leary.

J262 Robbins, Trina. "June Mooney, Head Agent." Swift Comics (New York: Bantam), pp. [64-93]. References to Leary are made in this underground comic strip set in the year 1998.

J263 Schneider, Walter. Millbrook Thanksgiving. (Mendocino, Calif.: Mad River Press). A memoir, written partly in prose and partly in poetry, of Leary's Millbrook period, with which the author was closely involved.

J264 Wallace, John. Psychology: A Social Science. (Philadelphia: Saunders), pp. 271-72. Leary's work in interpersonal relationships is viewed as a third perspective following those of Freud and Rogers.

J265 Watts, W. David, Jr. The Psychedelic Experience: A Sociological Study. (Beverly Hills, Calif.: Sage Publication), pp. 116-19, 152-54, 161-62, 226-29. Leary's actions and ideas are assessed from a sociological standpoint.

J266 Young, Jock. The Drugtakers. (London: MacGibbon \& Kee), pp. 151-52. Refers to Leary's "non-game" community in Zihuatenejo, Mex.

\section{2}

J267 “An Interview with Kathleen Cleaver." Black Perspective (Jan.): 13, 15-16. Kathleen Cleaver discusses the Black Panther party's treatment of Leary in Algeria.

J268 Siegel, Ronald. "Psychedelics Revisited." The Rip Off Review of Western Culture, no. 1 (June-July): 54-55. Lengthy reviews of High Priest (A7) and Politics of Ecstasy (A8).

J269 Duncan, D. F. "Psychedelic Drugs in Correctional Treatment." Crime \& Delinquency (July). Reprinted in Drugs in Institutions, U.S. Senate Hearings, July 31 and Aug. 18, 1975. (Washington, D.C.: GPO), pp. 
330-36. "The earliest study on the use of psychedelic drugs in correction was conducted by Timothy Leary . . . and Walter Houston Clark [AA41]. . . . The results indicate that such drugs may have a useful and important role to play in modern correction."

J270 Kahn, Kenneth, and Sherri Kahn. "Notes from Underground. Leary Stays High.” Berkeley Barb (Aug. 25-31): 5, 8. Account of a meeting with Leary in Swiss exile.

J271 "Bantam Has World Rights to Timothy Leary's Escapades." Publisher's Weekly (Sept. 25): 44. Escapades was the working title of Confessions of a Hope Fiend (A14), Leary's most newsworthy book.

J272 “'Brotherhood of Eternal Love' Drug Cult Cracked in Federal, State, Local Operation." BNDD Bulletin (Winter 1972/73): 22-23. "Leary . . . was named as one of the key figures. . . . Bail for Leary had been set at $\$ 5$ million." Report of the Bureau of Narcotics and Dangerous Drugs (BNDD).

J273 Bergin, Allen E., and Hans H. Strupp. Changing Frontiers in the Science of Psychotherapy. (Chicago and New York: Aldine-Atherton), p. 251. Arnold P. Goldstein, professor of psychology, Syracuse University, "made the significant point that individuals like Leary, [Carl] Rogers, and [William] Schutz have left the university setting, evidently feeling that the important variables do not lie in analogue research, in the laboratory, or in traditional clinical settings."

J274 Brecher, Edward M. Licit \& Illicit Drugs. (Boston: Little, Brown), pp. 368-69 passim. Traces Leary's "strange odyssey" from Harvard to exile in Switzerland, and how "each crackdown . . . served to publicize LSD more widely."

J275 Dahlstrom, W. Grant; G. S. Welsh and Leona E. Dahlstrom. An MMPI Handbook. Revised ed. (Minneapolis: University Minnesota Press), vol. I (1972), pp. 86, 88, 239, 242; vol.II (1975), pp. 112-13. Discussion of Leary's Interpersonal Diagnostic indices, with reproduction of table from Interpersonal Diagnosis of Personality (A3); the use of MMPI profile patterns in his system.

J276 Dittman, Allen T. Interpersonal Messages of Emotion. (New York: Springer), pp. 185-86. Mention of Leary's early '50s work defining public, conscious and private levels of personality.

J277 Freeman, Robert Michael. Psychopharmacology and Politics: Timothy Leary's Theory of Revolution. (Tucson: University of Arizona). Ph.D. dissertation submitted to the Department of Government, University of Arizona. 
J278 Harrington, Alan. Psychopaths . . (New York: Simon \& Schuster), pp. 255-71. The novelist, whom Leary had turned on to LSD in 1963, provides a complex analysis of Leary and his impact on the period.

J279 King, Rufus. The Drug Hang-Up: America's Fifty-Year Folly. (New York: Norton), pp. 147, 292-93, 308, 366. Leary's run-ins with the law (e.g., Leary v. U.S.) are considered.

J280 Labin, Suzanne. Hippies, Drugs and Promiscuity. (New Rochelle, N.Y.: Arlington House), pp. 61-71 passim. A critique of Leary and his views, containing several lengthy quotations from his writings and talks.

J281 Lorr, M.; P. F. Bishop and D. M. McNair. "An Interpersonal Behavior Circle" and "Expansion of the Interpersonal Behavior Circle," in Changing Frontiers in the Science of Psychotherapy, ed. A. E. Bergin and H. H. Strupp. (Chicago: Aldine-Atheron), pp. 68-75, 823-30. Lengthy analysis of the Interpersonal Behavior Circle developed by Leary et al.

J282 Watts, Alan. In My Own Way. N.Y.: Pantheon, 347-53 passim. Description of author's interactions with Leary at Harvard. "Timothy was the center of a vortex which pulled in the intellectually spiritual and adventurous."

J283 Weil, Andrew. The Natural Mind. (Boston: Houghton Mifflin), pp. 27-30 passim. Description of author's involvement with Leary and Richard Alpert while an undergraduate student at Harvard in the early '60s.

J284 Zaehner, R. C. Zen, Drugs and Mysticism. (New York: Pantheon), pp. 70-87, 112-18, 132-34, 208-9. An analysis of Leary's ideas regarding the relation of psychedelic drugs to mysticism and sexuality.

J285 Zinberg, Norman, and John A. Robertson. Drugs and the Public. (New York: Simon \& Schuster), pp. 172, 250. Case of Leary v. U.S. noted.

\section{3}

J286 Kunkin, Art. "The Capture of Tim Leary." Los Angeles Free Press (Jan. 26-Feb. 4):1, 3, 22. First in-depth coverage of Leary's return to the United States in the company of Joanna Harcourt-Smith under bail of $\$ 5$ million.

J287 Slack, Charles. "Tim the Unsinkable." Psychology Today (Jan.):54-55. Prepublication excerpt from a book (J335) by a former Harvard associate of Leary. 
J288 Preminger, Otto. "Interview." Penthouse (Jan.):56. The film director describes Leary's presence at the former's first LSD trip on the set of the film Skidoo (G10).

J289 Maxwell, Evan. "Dream of Universal Love Shattered by Drugs." Los Angeles Times (Feb. 20):Part II:1, 8. Account of the Brotherhood of Eternal Love and Leary's involvement with them, largely drawn from police sources following their indictments on drug charges.

J290 Cardoso, Bill. "Tim Leary and the Long Arm of the Law." Rolling Stone (Mar. 15):1, 20, 22. Traces the story of Leary from link-up with Joanna in Switzerland, to their arrest in Afghanistan, and his return to jail in Calif.

J291 Palmtag, Dinah. Special Report on the Leary trial. San Luis Obispo Sun-Bulletin (Mar. 29-Apr. 5). Local reporter's in-depth coverage of Leary's trial for prison escape.

J292 Levy, Alan. "Tim Leary, Won't You Please Come Home?" Penthouse (Mar.):40-42, 120-22, 133. Description of meeting with Leary in Switzerland prior to his recapture.

J293 Pearlstein, Howard J. "Timothy Leary: Time Traveler as Fun and Prophet." City (Sept. 19-25):23-26. General account of Leary's life and thought.

J294 Lipsky, Jon. "Tim Leary's Last Trip: Contact from Outer Space." The Real Paper (Oct. 21):1, 8-10. Report on Leary in Folsom Prison writing Terra II (A16) with excerpts from the book; also author reviews the film At Folsom Prison (G16).

J295 McCabe, Charles. "The Fearless Spectator" column in San Francisco Chronicle (Oct. 24-25). Two-part discussion of the legal suit brought by Leary and other prisoners at Folsom Prison against the state of Calif.

J296 "Word from Folsom Prison." New Yorker Dec. 3):44-45. Leary's prison situation is discussed in the "Talk of the Town" section.

J297 Kleps, Art. "The Excommunication of Timothy Leary." Divine Toad Sweat (Dec. 7): 1-6. Entire issue of this Neo-American Church newsletter is devoted to this article.

J298 Neff, Renfreu. "Tim Leary: Canterbury Tales on the Swiss Riviera." Changes (Dec.-Jan.):12, 38. Account of Leary in Swiss exile.

J299 "Gwyddion." "The Pied Piper: The Story of Timothy Leary." Beanstalk, no. 3:7-20. Portrayal of Leary as "the Pied Piper of our time, a Merlin Magician . . . one of those destined to change our history and our lives." 
J300 Altman, Irwin, and Dalmas A. Taylor. Social Penetration: The Development of Interpersonal Relationships. (New York: Holt, Rinehart \& Winston), pp. 19-20. Leary's "five levels of personality structure deriving from interpersonal psychoanalytic theories," and their similarity to Erich Fromm's structure.

J301 Charters, Ann. Kerouac: A Biography. (San Francisco: Straight Arrow Press), p. 363. Reference to Kerouac's psilocybin mushroom trip, taken in the company of Leary at Harvard in 1961.

J302 Clark, Walter Houston, et al. Religious Experience: Its Nature and Function in the Human Psyche. (Springfield, Il.: Thomas), pp. 17, 44, 55,81 . Discusses Leary's importance in "the study of the religious agency of [psychedelic] drugs."

J303 De Ropp, Robert. The New Prometheans. (New York: Delta Books), pp. 207-8. Critique of Leary's influence on the period.

J304 El Perfecto Comics. Berkeley. 32 pp. Printed inside front cover: "El Perfecto is an artist's benefit comic book for the Timothy Leary Defense Fund." Contributors include: R. Crumb, Justin Green, Kim Deitch, Willy Murphy, Shelby, Bobby London, Rick Griffin, Victor Moscoso, Ted Richards, Gilbert Shelton, Trina Robbins, Diane Noomin, Lee Marrs, Michelle Brand, Jay Kinney, Spain Rodriguez, Sharon Rudahl, Rory Hayes, and others. Many of the comics deal directly with Leary.

J305 Hollingshead, Michael. The Man Who Turned On the World. (London: Blond \& Briggs). (1st American ed.: New York: Abelard Schuman, 1974.) Author obtained 5,000 doses of LSD from Sandoz Pharmaceutical Laboratories in 1960, went to Harvard and distributed the drug to Timothy Leary and other members of his Psychedelic Research Project, who up to this time were using the milder psilocybin in their work.

J306 Johnson, Bruce D. Marijuana Users and Drug Subcultures. (New York: John Wiley \& Sons), pp. 94, 120, 151. "If we want to take Leary literally, we should call LSD 'Let's Start Degeneracy."

J307 Nahas, Gabriel G. Marihuana-Deceptive Weed. (New York: Raven Press), pp. 10, 278. Criticizes Leary and Allen Ginsberg for "reviving the cult of expanded consciousness through the use of cannabis and other hallucinogens."

J308 Perkins, D. M. Deep Throat. (New York: Dell), pp. 50-51. In this novelization of the most famous $\mathrm{x}$-rated movie ever made, the heroine's (Linda Lovelace's) orgasm is compared to "Timothy Leary taking acid for the first time." 
J309 Seed. (San Cristobal, N.M. and New York, N.Y.: Harmony Books), pp. 16-18. Reproduces Leary's Interpersonal Behavior Circle and quotes from Multilevel Measurement of Interpersonal Behavior (A2) and Psychedelic Prayers (A5).

J310 Sheridan, Dave. Jail Notes by Timothy Leary. Two-page strip in an underground comic book (title uncertain). Cartoon artist imagines Leary's subjective impressions of prison.

J310a Shepperd, Walt. Conjuring a Counter-Culture. (Paradise, Calif.: Dustbooks), pp. 24-27, 35. Chapter entitled "A New Manual of Arms for the High Priest" deals with Leary's involvement with the Black Panther party and Weather Underground.

J311 Sundberg, Norman D., Leona E. Tyler and Julian R. Taplin. Clinical Psychology: Expanding Horizons. 2d ed. (New York: Appleton Century Crofts), pp. 257, 368, 568. (1st ed.: 1962.) "Leary (1957) [A3] was one of the few psychologists who developed a system for measuring unconscious expressions, self-report, and observations of others on the same dimensions."

J312 Thorne, Frederick C. "An Eclectic Evaluation of Psychotherapeutic Models," in Direct Psychotherapies: 28 American Originals, ed. R. R. Jurjevich. (Coral Gables: University of Miami Press), vol.II, p. 847. Clinical psychologists should "study the personality factors causing a respected scientist to change into a mystic charlatan," while "publicly disassociating" themselves from Dr. Leary.

J313 Veysey, Laurence. The Communal Experience: Anarchist and Mystical Communities in Twentieth Century America. (Chicago: University of Chicago Press), pp. 437-38. Mention of Millbrook as "a communitarian setting," and the influence of Aldous Huxley, Gerald Heard and Alan Watts's ideas there.

J314 Wellesley, Gordon. Sex and the Occult. (London: Souvenir Press). (1st U.S. ed.: New York: New American Library, 1975), pp. 141-54. Author discusses Leary's writings in connection with sexual aspects of the psychedelic experience, quoting at length from the description of Leary's first experiment with magic mushrooms (High Priest, A7) and his interview in Playboy (AA47).

J315 Wiggins, Jerry S. Personality and Prediction: Principles of Personality Assessment. (Reading, Mass.: Addison-Wesley), pp. 428-30, 479-82 passim. An analysis of Leary's Interpersonal System of Personality Diagnosis, which "must be considered a milestone in the development of interpersonal assessment models." A simplified version of the Interpersonal Check List is reproduced (fig. 10.5). 
J316 Wilson, Robert Anton. Sex and Drugs: A Journey Beyond Limits. (Chicago: Playboy Press), pp. 8, 268-69 passim. Quotes Leary on imprinting, compares Leary and LSD with Einstein and the atom bomb, among numerous references.

\section{4}

J317 Griffith, Bill. "Zippy the Pinhead Meets His Maker." San Francisco Phoenix (Feb.). Zippy and Leary discuss space migration in cartoon format.

J318 Wilson, Robert Anton. "Leary: How to Live Forever." The San Francisco Phoenix (May 30):1, 10. Wilson visits Leary in Vacaville and discusses brain circuit theory and life extension.

J319 Crumb, Robert and Aline Kominsky. "Aline ' $n$ ' Bob's Funtime Funnies," in Dirty Laundry Comics No. 1 (July):10-12. Crumb and Kominsky are kidnapped by extra-terrestrials and then rescued by Leary's "Starseed" spacecraft. Leary resembles Captain Kirk of Star Trek.

J320 Warth, Mary Jo. "The Story of the Acid Profiteers." Village Voice (Aug. 23-30):5, 9. An account of the drug-dealing activities of Brotherhood of Eternal Love, with much reference to Leary and William Mellon Hitchcock.

J321 Long, Steve. "Is Tim Leary Finking on Weatherfolk?" Berkeley Barb (Aug. 23-29):5. Report on rumors of Leary cooperating with Federal authorities.

J322 Brown, Leonard. "Timothy Leary." Parts I \& II. Los Angeles, Free Press (Sept. 13-19; 20-26). The FBI's investigation of the seizure of Leary's archives.

J323 Zane, Maitland. "The Friends of Tim Leary: LSD King Called a Fink." San Francisco Chronicle (Sept. 19):23. Account of PILL (People Investigating Leary's Lies) press conference, with quotation from Ram Dass (Richard Alpert), Allen Ginsberg, Jerry Rubin, Jack Leary and Dr. Eugene Schonfeld.

J324 Bryan, John. "Whatever Happened to Timothy Leary?" San Francisco Phoenix (Sept. 26):1, 3. About the Brotherhood of Eternal Love, and the allegations of Leary's informing. See author's book of the same title (J416). 
J325 Ginsberg, Allen. "Ginsberg Asks 44 Questions About Leary." Berkeley Barb (Sept. 20-26): 1. "Is [Leary] trying to clean the Karma blackboard by creating a hippie Watergate? Will he be pardoned by the next guru?"

J326 Drosnin, Michael. "Nixon's Radical Chaser Bags a Whopper." New Times (Oct. 18):18-24. About Leary's presumed relationship with the United States Justice Department.

J327 Gustaitis, Rasa. "Is Tim Leary's Joanna a Nàrc?" New Times (Oct. 18): 26-29. In-depth account of the events behind Leary's being held incognito by federal authorities, focusing on the role of Joanna Harcourt-Smith Leary and the seizure of Leary's archives from Michael Horowitz.

J328 Wilson, Robert Anton. "Strongly Differing View on Tim." San Francisco Phoenix (Oct. 24):1, 5, 7. A thorough documentation of Leary's scientific work, and his persecution for his ideas.

J329 Martino, Dennis. "Tim Leary's Narc Friend Denounces PILL People." Berkeley Barb (Dec. 13-19):1-2. Scathing attack on PILL (People Investigating Leary's Lies) by a former Leary associate turned informer.

J330 Leary, Joanna Harcourt-Smith (a.k.a. Joanna Harcourt-Smith). "Interview." Rama, no. 14 (special number, undated), pp. 20-22, 32-33, 48. In-depth interview with the chief spokesperson for the imprisoned T. Leary.

J331 Alpert, Richard (Ram Dass). The Only Dance There Is. (Garden City: Doubleday), p. 14. Assessment of Leary ("a great visionary") and LSD.

J332 Horowitz, Michael, et al. Apologia for Timothy Leary. With a Selected Bibliography. 72 pp. (San Francisco: Fitz Hugh Ludlow Memorial Library). A biographical sketch of Leary, illustrated with title pages of his books, followed by a "Selected Bibliography of Published Works, 1946-1974." This booklet (modelled on John Dee's Discourse Apologetical, London, 1603) was prepared by Leary's archivist and his associates (John James, Carol Tickner, Dana Reemes, Chip Roberts, Cindy Palmer and Robert Barker) to help gain Leary's release from prison. Five hundred copies printed (350 bound). A six-page insert, "Update: July 1974 - February 1975," was added to remaining copies in February 1975.

J332a Jones, Hardin B. Remarks in Marihuana-Hashish Epidemic and its Impact on United States Security . . . Hearings . . . United States Senate . . May-June 1974 . (Washington, D.C.: GPO), pp. 212, 215, 223-24, 226, 228. Attacks Leary, quoting from the author's works. 


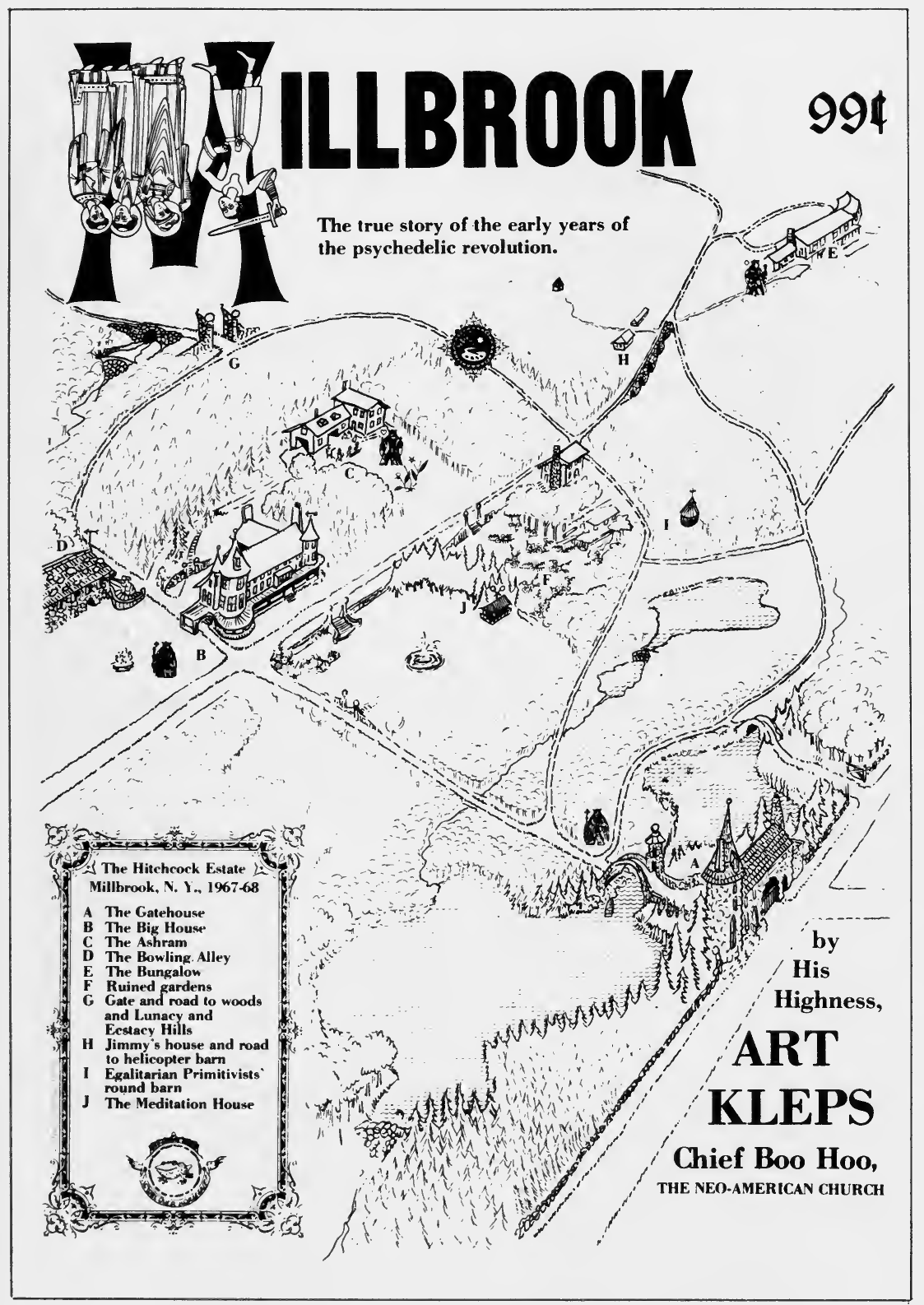

J333: Map of Leary's Millbrook, N.Y. estate on the cover of the tabloid printing of Art Kleps's memoir. 
J333 Kleps, Art. Millbrook: The True Story of the Early Years of the Psychedelic Revolution. (North Troy, Vt.: the Author.) Original tabloid format printed in three columns, with map of the estate on cover. The author founded the Neo-American Church while living at Millbrook. Book format: Oakland: Bench Press, 1977. Episodes appeared in The Sun, nos. 1-2 (Feb.-Mar. 1974).

J334 Osmond, Humphry. Understanding Undersţanding. (New York: Harper \& Row), pp. 95-98. Account of a visit made with Aldous Huxley to Timothy Leary at Harvard, and a critique of Leary's views on psychedelic drugs.

J335 Slack, Charles W. Timothy Leary, the Madness of the Sixties and Me. (New York: Peter H. Wyden). A full-length book about the author's encounters with Leary. Both were clinical psychologists who taught at Harvard. Portions of the book appeared under the title "Tim the Unsinkable" in Psychology Today (J287) and "An Evening with Timothy Leary" in Eye Magazine (J143).

J336 Wavy Gravy (pseud. of Hugh Romney). The Hog Farm and Friends by Wavy Gravy as told to Hugh Romney and Vice Versa. (New York and London: Links Books), p. 55. Contains a description of Leary's appearance at the LEMAR (Legalization of Marijuana) Convention in 1968. "Leary's got a smile like a searchlight . . . [he's] really a showman and knows about how to give stage."

J337 Wilson, Robert Anton. "The Scientific Contributions of Dr. Timothy Leary, 1957-74." Fragment (pp. 44-132) of an unpublished typescript, complete in itself. The first work of its kind. Some of the material was incorporated in J328 and in the author's The Cosmic Trigger (B33).

\section{5}

J338 Kesey, Ken. "Search for Communication with Higher Intelligence," dated Pleasant Hill, Ore. Jan. 1. 17 pp. Novelist's privately distributed account of his interactions with Leary over the years. Not published.

J339 Long, Steve. "In Search of Tim Leary." Berkeley Barb (Feb. 14-20):1-3. Coverage of Berkeley "Wake Up" event held to investigate Leary's political imprisonment, with statements by Ken Kesey, Robert Anton Wilson, Paul Krassner, Carol Tickner and Michael Horowitz.

J340 Long, Steve. "Leary Clarifies His Stand." Berkeley Barb (Feb. 28-Mar. 6):5. Leary and Robert Anton Wilson discuss their theories (The Periodic Table of Energy). 
J341 Thompson, Tom. "The Drug Puzzle," Parts I \& II. Los Angeles Free Press (Mar. 29 and Apr. 4). Investigation of the informant charges against Leary.

J342 Liddy, G. Gordon. "The Great Dutchess County Dope Raid." True (June): 28-31, 75-79. The story of Liddy's raid on Millbrook in 1966. Reprinted in the author's Will (J431).

J343 Krassner, Paul. "The Love Song of Timothy Leary." Arcade, no. 1 (Spring):16-18. Thoughts on Leary's informing, illustrated by Spain Rodriguez.

J344 Weir, David. "Tim Leary: Soul in Hock." Rolling Stone (Aug. 28): 23-24, 28. Concerning Leary as informer.

J345 Vetter, Craig. "Bring Me the Head of Timothy Leary." Playboy (Sept.): $89,96,104,204-5,210-12$. Investigation of the role of Joanna Harcourt-Smith Leary in the capture of Leary and rumors of his informing to federal authorities.

J346 Long, Steve. "Dr. Timothy Leary and the San Francisco Grand Jury." Los Angeles Free Press (Sept. 5-11):5, 30. Statements by Michael Horowitz, Robert Anton Wilson, Lawrence Ferlinghetti, Muriel Rukeyser and others on the politics of the Leary situation.

J347 Ashley, Richard. "The Other Side of LSD." New York Times Book Review (Oct. 19):46-48, 50. Leary's relevance to the LSD movement.

J348 Rukeyser, Muriel. "Presidential Papers." American PEN Society Newsletter, no. 24 (Nov.):1. Refers to her support, on behalf of American P.E.N. Society, of Leary archivist Michael Horowitz, facing a grand jury investigation.

J349 Bonewitz, Isaac. "Aquarian Anti-Defamation League News." Green Egg (Dec. 21):23. Speculations on Leary's whereabouts by the well-known magician.

J350 Hollingshead, Michael. High Times, no. 3 (Winter):19-21. Memories of Leary at Harvard and Millbrook in an interview conducted by Peter Stafford.

J351 Darlington, Andy. "Timothy Leary—Politics of a Hope Fiend." Ludd's Mill:11-16, 18, 22. Lengthy article subtitled "The Most In-depth Journey into the Mid-60's Acid High Priest Ever." Published in West Yorkshire, Eng.

J352 Eisner, Bruce. "Notes on Dr. Timothy." Marijuana Monthly, vol. I, no. 5:30-31. Short biography and update of Leary's present circumstances in federal custody. 
J353 Arguelles, Jose A. The Transformative Vision. (Berkeley: Shambhala), pp. 264, 269-70, 280 passim. "In Leary, the wildest dreams of the Surrealists and the most beatific visions of the [Romanticists and Symbolists] were to be combined in a disquietingly charismatic and catalyzing force."

J354 Benitez, Fernando. In the Magic Land of Peyote. (New York: Warner), pp. 82-83, 92-96. (1st ed: University Texas Press, 1975.) Critique of Leary's ideas on LSD's religious and sexual aspects, with lengthy quotation.

J355 Krippner, Stanley. The Song of the Siren: A Parapsychological Odyssey. (New York: Harper \& Row), pp. 20-24, 31-40, 44-45. Description of the author's encounters with Leary at Harvard and later at Millbrook.

J356 Masterson, Sharon. "The Adjective Checklist Technique: A Review and a Critique," in Advances in Psychological Assessment, ed. P. McReynolds. (San Francisco: Jossey-Bass), vol. III, p. 279. Use of adjectives in the Interpersonal Check List.

J357 Yalom, Irwin D. The Theory and Practice of Group Psychotherapy. 2d ed. (New York: Basic Books), pp. 251-53. (1st ed.: 1970.) “There have been two recent noteworthy attempts to arrive at a comprehensive, quantified, interpersonal diagnostic system: the interpersonal circular grid of Timothy Leary and the FIRO-B system of William Schutz." Leary's grid is discussed and illustrated.

\section{6}

J358 Cleaver, Eldridge. "Conversation with Eldridge Cleaver." Oui (Jan.): 114-15. Cleaver talks about the experience of sheltering and then arresting Timothy and Rosemary Leary in Algeria.

J359 Kleps, Art. "Interview." High Times, no. 8 (Feb.-Mar.): 21-24. Recollections of Leary at Millbrook.

J360 Riley, John. "Timothy Leary Is Free, Demonstrably in Love and Making Extraterrestrial Plans." People (May 31):24-26. Exclusive story of the recently-freed Leary.

J361 Wallace, Bill. "Libertarians: Left Meets Right." Berkeley Barb (July 22-28). Leary gives the introductory address on space migration to the Libertarian Party Convention in San Francisco. 
J362 Wilson, Robert Anton. "Timothy Leary is Loose Again and Headed for the Stars." Psychic, no. 4 (Sept./ Oct.):8-14. An update on Leary's life, outlining the "8-calibre brain" and discussing movement into space.

J363 Stafford, Peter and Bruce Eisner. "Who Turned on Whom." High Times, no. 26 (Oct.):45. Leary's influence on the spread of the psychedelic culture.

J364 Hoffman, Abbie. "Hoffman to Leary: Brainwashing is Gobbledygook." Oui (Oct.): 9. Open Letter to Leary, taking issue with the ideas expressed in the latter's article, "Brainwashing" (C99).

J365 Goldsmith, Don. "Mine the Moon, Seed the Stars." Mother Jones (Nov.):14-20. Discussion of space migraton drawing heavily on Leary and Gerard O'Neill.

J366 Bryan, John. Four excerpts from Whatever Happened to Timothy Leary? Berkeley Barb, nos. 593-96 (Dec. 1976-Jan. 1977). Bryan's "unauthorized biography" appeared in 1980 (J416).

J367 Wilson, Robert Anton. "Leary As Libertarian." Up Against the Wall: [5-7]. "Dr. Leary as libertarian evolutionist proceeds logically from Leary as evolutionary psychologist and neurologician."

J368 DeRopp, Robert S. Drugs and the Mind. (New York: Delacorte Press), pp. 176-78, 183, 185. Describes Leary's career as "so colorful and peculiar that it might be regarded as a sort of psychedelic dream (or nightmare)."

J369 Hendin, Herbert. The Age of Sensation: A Psychoanalytic Exploration. (New York: Norton), pp. 10, 12, 202, 324. Refers to Leary's "mysticism of cells" and other of his ideas.

J370 Hoffman, Anita and Abbie Hoffman. To America with Love: Letters from the Underground. (New York: Stonehill), pp. 101-4. Yippie leader's thoughts after reading that Leary is talking to the FBI.

J371 Johnstone, Edwin E., Thom K. Roberts and James L. Claghorn. "Strategies for Chronic Psychotics," in Successful Psychotherapy, ed. J. L. Claghorn. (New York: Brunner/Mazel), pp. 55-57. Modified version of "Leary's Interpersonal Battery" discussed and illustrated (fig. 1 and table 1).

J372 Nin, Anaïs. Diary, 1955-1966. (New York: Harcourt Brace Jovanovich), pp. 331-43. Author reflects on her meetings with Leary in 1963: his ideas ("Leary's talk about the games, the disguises, the false life, made perfect sense to me"), his personality, his mistake in going to Mexico. 
J373 Reisman, John M. A History of Clinical Psychology. Enlarged ed. (New York: Irvington), p. 365. Notoriety of a "once respected clinical psychologist."

J374 Smith, Adam. Powers of Mind. (New York: Ballantine), pp. 42-44. (1st ed.: N.Y.: Random House, 1975.) Leary's place in the psychedelic movement.

\section{7}

J375 Naglin, Nancy. "The Man Who Fell to Earth." Crawdaddy (Mar.): 50-57. Wide-ranging profile with much quotation.

J376 Mano, D. K. "Faces of Timothy Leary." National Rev. 29 (Apr. 15): 449-50.

J377 Riggenbach, Jeff. "Timothy Leary's New Trip: A Reason Interview." Reason, no. 12 (Apr.):30-34. Reason "was curious about Leary's changing views and his reflections on a decade of facing the might of the United States government."

J378 Harris, Art. "The Timothy Leary Show." San Francisco Sunday Examiner (May 8):8, 12, 14. On Leary beginning a new career as stand-up comedian.

J379 Heimel, Cynthia. "Timothy Leary: Swarming in L.A." Weekly Soho News (Sèpt. 14):39, 84. "The Sunset Strip is the end of the Genetic Runway and thousands of the smartest people are skidding on to it," Leary tells the writer in L.A.

J380 Rumsey, Spencer. "“The Most Exquisite Rascals of the Age." Berkeley Barb (Oct. 21-27):7. Account of a reunion of LSD notables Leary, Albert Hofmann, Richard Alpert, Allen Ginsberg, John Lilly, among others, at a symposium "LSD-A Generation Later." Reprinted in Head, no. 8 (Mar. 1978).

J381 Dowling, Colette. "Confessions of an American Guru." New York Times Magazine (Dec. 4): 41-43, 136-49. A profile of Richard Alpert/ Ram Dass, including his association with Leary at Harvard.

J382 Clark, Walter H. "Tim Leary: A Personal Observation." Outpost, no. 1 (Winter):12-14. Clark thinks of Leary as "one of the pioneers in an intellectual ferment preliminary to many of the innovations to come in the next century."

J383 Drury, Neville. Don Juan, Mescalito and Modern Magic: The Mythology of Inner Space. (London: Routledge \& Kegan Paul), pp. 64-76. 
Critical history of Leary's involvement with psychedelic drugs, particularly his use of Tibetan Buddhist models, with extensive quotation.

J384 Knapp, Robert R., Everett L. Shostrom and Lila Knapp. "Assessment of the Actualizing Person," in Advances in Psychological Assessment, ed. P. McReynolds.(San Francisco: Jossey-Bass), vol. IV, p. 130. Credits the work of Leary et al. at the Institute of Personality Assessment, Berkeley, for the theory upon which the PAI (Pair Attraction Inventory) is based.

J385 Kramer, John C. "God Made Timothy Leary." Eleven-page unpublished typescript. A satirical one-act play.

J386 McCabe, O. Lee, and Thomas E. Hanlon. "LSD Psychotherapy," in Changing Human Behavior: Current Therapies and Future Directions, ed. O. L. McCabe. (New York: Grune \& Stratton), p. 246. Reference to Leary et al., "A New Behavior Change Program Using Psilocybin" (AA44c).

J387 Patton, Bobby R., and Kim Giffin. Interpersonal Communication in Action. 2d ed. (New York: Harper \& Row), p. 373. (1st ed., 1974). Numerous references to the Barron-Leary study (AA13) include a full-page outline of this work as reinterpreted by Cartwright (1956).

J387a Propper, Dan. The Tale of the Amazing Tramp. (Cherry Valley, NY: Cherry Valley Editions), p. 23. Poem entitled "For Leary on the Lam."

J388 Wilson, Robert Anton. Cosmic Trigger: Final Secret of the Illuminati. (Berkeley: And/Or Press), pp. 33-40, 47-50, 53-56, 174-76, 197-206, 211-13 passim. Describes personal encounters with Leary from Millbrook in 1964 to a federal prison in 1975, compares him with Wilhelm Reich and discusses his theory of neurological "circuits" and Periodic Table of Evolution.

\section{8}

J389 Capote, Truman. "Christmas Card." High Times. no. 32 (Apr.): 52-54. Author's Christmas wish for Leary is "justice at last, a ten-year full professorship at Harvard."

J390 Bates, Anne-Marie. "Leary and Space Migration." Los Angeles Star (June):8. Description of Leary's talk at the Space Week Festival.

J391 Chayefsky, Paddy. Altered States. (New York: Harper \& Row). The protagonist of this novel (later a feature film starring William Hurt) is based upon a composite of John Lilly and Timothy Leary. 
J392 Goode, Erich. Deviant Behavior: An Interactionist Approach. (Englewood Cliffs, N.J.: Prentice-Hall), pp. 229-30. Account of Leary's career from 1960 to 1966.

J393 Horowitz, Michael. "The Psychedelic Revolution," in High Times Encyclopedia of Recreational Drugs. (New York: Stonehill), pp. 192-95 passim. Discusses Leary's place in the psychedelic movement. (Numerous references to Leary appear throughout the book.)

J394 Mullan, Hugh, and Max Rosenbaum. Group Psychotherapy: Theory and Practice. 2d ed. (New York: Free Press/Macmillan, p. 219. Traces the influence of psychoanalysts Otto Gross and Wilhelm Reich on Leary and R. D. Laing.

J395 Orlinsky, David E., and Kenneth I. Howard. "The Relation of Process in Psychotherapy," in Handbook of Psychotherapy and Behavior Change: An Empirical Analysis, ed. S. L. Garfield and A. E. Bergin. 2d ed. (New York: John Wiley \& Sons), p. 292. "One of the most familiar and widely utilized schemes for studying interpersonal behavior is that developed by Leary and his associates."

J395a Plympton, Bill. Medium Rare. (New York: Holt, Rinehart \& Winston), p. [16]. Pen and ink caricature of Leary smiling though wearing prison leg irons.

J396 Stevens, Mark. "Tim Leary, Bob Dylan-and the Arena of Consciousness." The Lightning Herald, no. 1 (June):30-32. Takes issue with Leary's attack on Dylan's music in Rocky Mountain Musical Express (Nov. 1977).

J396a Weyr, Thomas. Reaching for Paradise: The Playboy Vision of America. (New York: Times Books), pp. 144-46. Traces Leary's involvement with Playboy during the '60s. "He articulated the link between drugs and sex."

J397 Miller, Michael E. "Timothy Leary Wants to Increase Your Intelligence." San Francisco Bay Guardian (Jan. 17-26):27. Leary describes himself as "an intelligence agent."

\section{9}

J398 McLemore, Clinton W., and Lorna Smith Benjamin. "Whatever Happened to Interpersonal Diagnosis? A Psychosocial Alternative to DSM-III." American Psychologist 34, no. 1 (Jan.): 19-26, 29-30. "The concept of interpersonal diagnosis was most elaborated by Timothy Leary [whose] brilliant research career included detailed, careful study of ways to dimensionalize social behavior." Fig. 1 and table 1 are reprinted from his works. 
J399 Nelson, Harry. "LSD Pioneers Look Back-and Reassess. Los Angeles Times (Mar. 7):1, 29-30. Account of a reunion of psychedelic researchers hosted by Oscar Janiger in Los Angeles.

J400 Breger, Udo. "Die Nova Convention." Sphinx, no. 4 (Mar.):18-21. Report on the Nova Convention held in New York in Nov. 1978, in which Leary participated with William Burroughs, Allen Ginsberg, Robert Anton Wilson and Brion Gysin. Printed in Basel. See F22 for recording of this event.

J401 Bowart, Walter H. "How the CIA Planned the Drugging of America." Gallery (Sept.):50-52, 96-99. Investigation of the CIA MKULTRA program of mind control with drugs and the possibility that Leary was used as an "unwitting agent." In Berkeley Spectator (May 31-June 6, 1979), Leary claims Bowart misunderstood him.

J402 Hollingshead, Michael. "Highlights." Hi Life, no. 10 (Oct.):29. Lengthy quotations from Leary and others attending LSD Colloquium II in Los Angeles, Feb. 1979.

J403 Golowin, Sergius. Timothy Leary in the Swiss Highlands. Sphinx, no. 7 (Dec.):19. Swiss author-historian Golowin met Leary when the latter was living in exile in Switzerland.

J404 Bates, Anne-Marie. "Tim Leary at the Improv." Los Angeles Star, no. 194: 8. Leary explains his recent arrest arising from his and his wife Barbara's making "loud love" on ketamine.

J405 Eisner, Bruce, and Peter Stafford. "Time-Tunnels into the '80s." Blotter, no. 4: 60-65. Lengthy account of the reunion of psychedelic pioneers at $\mathrm{Dr}$. Oz Janiger's home in Los Angeles.

J406 De Ropp, Robert. Warrior's Way. (New York: Delta), pp. 280-87. Author decides Leary is not a "Warrior" because he does not know when to remain invisible.

J407 Goldman, Albert. Grass Roots: Marijuana in America Today. (New York: Harper \& Row), pp. 68-69. Compares Leary and Mezz Mezzrow, both of whom "turned on a new generation to a new drug."

J408 Grinspoon, Lester, and James B. Bakalar. Psychedelic Drugs Reconsidered. (New York: Basic Books), pp. 63-70, 211-13 passim. Gives a summary of Leary's career, a separate account of his work in prisoner rehabilitation and a lengthy quotation from High Priest (A7).

J409 Marks, John. The Search for the "Manchurian Candidate": The CIA and Mind Control. (New York: Times Books), pp. 117-18, 122. The CIA's interest in psilocybin research in Mexico and Harvard at the same time as Leary's. 
J410 McNally, Dennis. Desolate Angel: Jack Kerouac, the Beat Generation and America. (New York: McGraw-Hill), p. 273. Reference to Kerouac's psilocybin trip with Leary at Harvard in 1961.

J411 Sloman, Larry. Reefer Madness: The History of Marijuana in America. (Indianapolis: Bobbs-Merrill), pp. 229, 230, 373. Refers to the role of Leary and Allen Ginsberg in spreading the marijuana culture in the 1960s.

\section{0}

J412 Krassner, Paul. "My Acid Trip with Groucho." High Times (Feb.), pp. 43-44. Recounts his interactions with Leary as publisher of The Realist.

J413 Toy, Eckard V. "The Conservative Connection: The Chairman of the Board Took LSD Before Timothy Leary." American Studies, no. 2 (Fall):65-78.

J414 Barritt, Brian. "Hotel California, Sci-Fi Style." Homegrown, no. 6: 7-11. (London.) The author of Whisper and his family visit Leary in Los Angeles and discuss migration to the stars.

J415 Anthony, Gene. The Summer of Love: Haight-Ashbury at Its Highest. (Millbrae, Calif.: Celestial Arts), pp. 68-69. Five unpublished photographs of Leary with captions.

J416 Bryan, John. Whatever Happened to Timothy Leary? (San Francisco: Renaissance Press). Self-described "unauthorized history" that "attempts to put the man and his era into the perspective of history." With selective bibliography and illustrations. See J324 and J366 for earlier appearances.

J417 Bulkley, Dwight. Psycles. (Indianapolis: Bobbs-Merrill), pp. 234-35. Discussion of the relationship of Leary and John Griggs of the Brotherhood of Eternal Love.

J418 Bush, Patricia J. Drugs Alcohol \& Sex. (New York: Marek), pp. 213-21. Discussion of Leary's statements about the value of LSD as an aphrodisiac, with extensive quotation from the Playboy interview (AA47).

J419 DeVoge, J. T. "Reciprocal Role Training: Therapeutic Transfer as Viewed from a Social Psychology of Dyads," in Improving the Long-Term Effects of Psychotherapy, ed. Paul Karoly and J.J. Steffen. (New York: Gardner Press), pp. 342-48. Lengthy discussion of Leary's Interpersonal Diagnostic system. 
J420 Grof, Stanislav. LSD Psychotherapy. (Pomona, Calif.: Hunter House), pp. 37, 243-44. Refers to the use of psilocybin in the Concord Prison Project.

J421 Hoffman, Abbie. Soon to Be a Major Motion Picture. (New York: Perigree Books), pp. 90-91, 253-56. Political activist's view of Leary's activities in the late '60s and the Yippie involvement with Leary and the Black Panther party in Algeria in the early '70s.

J422 Hofmann, Albert. LSD: My Problem Child. (New York: McGraw-Hill), pp. 73-80. The LSD discoverer's experiences with Leary are presented in two consecutive sections, "The Case of Dr. Leary" and "Meeting with Timothy Leary." A German edition (LSD-Mein Sorgenkind) appeared in 1979.

J423 Kruger, Henrik. The Great Heroin Coup: Drugs, Intelligence, and International Fascism. (Boston: South End Press), p. 175. Alleges a connection between the Brotherhood of Eternal Love (which he says exploited Leary) and fugitive financer Robert Vesco.

J424 Masserman, Jules H. Principles and Practice of Biodynamic Psychotherapy. (New York: Thieme-Stratton), pp. 54, 84. Describes Leary's system of psychedelic therapy as "transcendent medication."

J425 Rachman, S. J., and G. T. Wilson. The Effects of Psychological Therapy. 2d enlarged ed. (Oxford: Pergamon Press), pp. 101, 241 passim. Altogether nine pages contain references to Barron and Leary, 1955 (AA13).

J425a Wilson, Robert Anton. The Illuminati Papers. (Berkeley: And/Or Press), pp. 87-88, 147-48 passim. Numerous references to Leary by his sometime literary collaborator include discussion of the brain circuits described in Neurologic (A13) and innovative space colonies.

\section{1}

J426 Anderson, Patrick. High in America. (New York: Viking), p. 130. Leary named as "subversive force" by Senator James Eastland's Congressional Subcommittee on Internal Security in 1975.

J427 Anson, Robert Sam. Gone Crazy and Back Again: The Rise \& Fall of the Rolling Stone. (New York: Doubleday), pp. 56-60, 319-21 passim. Critique of Leary's role in the '60s.

J428 Hampden-Turner, Charles. Maps of the Mind. (London: Mitchell Beazley), pp. 120-23. Map 34 is the Leary-Coffey Interpersonal Behavior Circle, which the author, in his lengthy analysis, considers 
"remarkably fertile" and "the most useful" interpretation of Harry Stack Sullivan's theory of personality.

J429 Marlan, Stanton. "Depth Consciousness," in: The Metaphors of Consciousness, ed. R. S. Valle and R. von Eckartsberg (New York: Plenum), pp. 225, 228-29. 232-32, 235, 241. References to Leary's Exo-Psychology, unusual for psychiatric literature.

J430 Shostrom, Everett L. and Dan Montgomery. "Actualizing Therapy," in: Handbook of Innovative Psychotherapies, ed. Raymond J. Corsini. (New York: Wiley \& Sons), pp. 1, 2. "The theoretical underpinning of Actualizing Therapy came from research at the Institute of Personality Assessment at Berkeley by Leary, Frank Barron, MacKinnon, and Hubert Coffey."

J431 Liddy, G. Gordon. Will. (New York: Dell), pp. 147-64. (1st ed., 1980.) Author's account of the raid he led on Leary's Millbrook commune in 1966. This text originally appeared in True (J342).

\section{2}

J432 "Leary Lectures at Harvard for First Time in 20 Years." New York Times (Apr. 25). On the return of Leary and Alpert to Harvard twenty years after they were fired from the Psychology Department there.

J433 “Scenes from a Marriage." Light Times: [2-6]. Presents dialogue from the film, Return Engagement (G20), about the Leary-Liddy debates.

J434 Brammer, Lawrence M., and Everett L. Shostrom. Therapuetic Psychology. 4th ed. (Englewood Cliffs, N.J.: Prentice-Hall), p. 89 and fig. 10. "Leary (1957) [A3] brought the concept of polarities . . . to the center of personality theory. This concept . . . is central to actualizing counselling and therapy." Fig. 10 is an Actualizing Model similar to the Interpersonal Check List.

J435 Brian, Dennis. The Enchanted Voyager: The Life of J. B. Rhine. (Englewood Cliffs, N.J.: Prentice-Hall), p. 251. Refers to Arthur Koestler and Leary suggesting to J. B. Rhine the value of psychedelic drugs for parapsychological research.

J436 Claire, Rodger. "A Scrambled Conversation with the Chicken Man." Cheech and Chong's Comedy Film Festival Magazine. (Santa Monica, Calif.: Ritter/Geller Communications), pp. 32-33. A satirical piece on Leary in the form of a mock interview, apparently conducted by Rodger Claire. 
J437 Davis, Abraham and Ralph Kolodny. "The Contemporary Family and the Responsibilities of the Social Worker in Direct Practice," in Controversy in Psychotherapy, ed. H. S. Strean.(Metuchen, N.J.: Scarecrow Press), p. 121. Comparison of the psychological approaches of B. F. Skinner and Leary.

J438 Davison, Gerald, \& John M. Neale. Abnormal Psychology. (New York: John Wiley \& Sons), pp. 6, 333. Proposes future generations will trace the genesis of the modern drug culture to Leary's initial "magic mushroom" experience in Mexico, or his and Richard Alpert's departure from Harvard, or the publication of Aldous Huxley's The Doors of Perception.

J438a Thurman, Judith. Isak Dinesen: The Life of a Storyteller. (New York: St. Martins Press), pp. 482-83. Recounts visit made by Aldous Huxley and Leary to Dinesen's Denmark home in 1961, where the three swapped tales of psychoactive drug experiments.

J439 Gold, Herbert. Review of Flashbacks. New York Times Book Review (July 3). Tongue-in-cheek review by the novelist. "He was just horsing around and happened to turn into the Messiah."

\section{3}

J440 Fields, Rick. "Flashback and Flash Forward: Psychedelics in the '80s." New Age, no. 98 (July):39-42. Account of Leary and Alpert's 1983 reappearance at Harvard.

J441 Buryn, Ed. Vagabonding in the U.S.A.: A Guide to Independent Travel. (San Francisco: Buryn Publications), pp. [3], 389. Author, who dedicates book to "Tim Leary, Vagabond Extraordinaire," thinks Leary "could be the most important man alive today."

J442 Javna, John, and Gordon. 60s! (New York: St. Martin's Press), pp. $210-11$. List of " 10 questions you would have been asked before they would let you in Leary's Millbrook commune." Satire.

J443 Lee, Martin A., and Bruce Schlain. "Timothy Leary." Dictionary of Literary Biography 16: 344-51. Biographical account focusing on Leary's relationship to the Beat Generation writers.

J444 Stafford, Peter. Psychedelics Encyclopedia. Revised ed. (Los Angeles: Tarcher), pp. 50-52, 239-43, 271-72, 314-15, 326-27 passim. Leary's place in the psychedelic movement is described and analyzed. (1st ed.: Berkeley: And/Or Press, 1977.) 
J445 Sundberg, Norman D., Julian R. Taplin and Leona E. Tyler. Introduction to Clinical Psychology. (Englewood Cliffs, N.J.: Prentice-Hall), pp. 116, 176. "Leary (1957) [A3] . . . developed a promising combination of interpersonal theory . . . with levels or kinds of perception of a person."

\section{4}

J446 Mehrin, Elizabeth. "People in the News: Timothy Leary." PC Magazine (Feb. 7):62. Leary explains why "computers are the psychedelic drugs of the '80s," and coins the slogan Tune In, Sign On, Boot Up.

J447 "Dau." "The History of the Communal Spiritual Movement: Kerista/ Judauism [sic]," in Kaliflower (Feb.):5. Co-founder of Kerista mentions meeting Leary and Richard Alpert in the Caribbean in the early 1960s.

J448 Santarelli, Mary-Beth. "Leary Experiments with Future Software." Software News (July). Electronic, "interactive books" as the literature of the future.

J449 Caruso, Denise. "Software Probes the Mind." InfoWorld, no. 39 (Sept. 24):34-39. "His SKIPI programming language is designed to work solo as a 'personal operating system' or with various 'very highly interactive' applications."

J450 Paioff, Jessica. "A Slice of Computer Pie." InfoWorld, no. 40 (Oct. 1):54. Review of Digital Deli (B43). Describes Leary's contribution as "a lucid piece on personal computers and personal freedom."

J451 Hoban, P. "Soul in the Software." Omni (Dec.):58. Article on a new trend in computer programming closes with a review of the PDB (Personality Data Base) capability of Leary's SKIPI program.

J452 [Wright, Dion]. "The Summer of Love, 1967: I. The Birth of Hippie." Irregular Quarterly III, no. 1, 55-64. Memoir of the period includes account of author's meeting with Leary at Millbrook.

J453 Matusow, Allen J. The Unraveling of America: A History of Liberalism in the 1960s. (New York: Harper \& Row). Leary's role in the 1960s as a link between Aldous Huxley and the Beat writers.

J454 Perry, Charles. The Haight-Ashbury: A History. (New York: Random House), pp. 159-63 passim. Leary's interactions with San Francisco hippies in the late 1960s. 
J455 Tendler, Stewart, and David May. The Brotherhood of Eternal Love. (London: Panther), pp. 45-71, 188-93, 239-45, 275-77 passim. Traces Leary's involvement with the largest group of underground LSD distributors.

\section{5}

J456 Talley-Jones, Kathy. "Timothy Leary, Psychometric Software, and You." Los Angeles Weekly (Mar. 22-28):21, 23. How Leary came to be a designer of a new type of computer game.

J457 Colker, David. "The New Timothy Leary Turns On with a Computer." Los Angeles Herald Examiner (May 21). The development and meaning of Leary's software game (Mind Mirror) [A26] and his new slogan: TFYQA (Think For Yourself, Question Authority).

J458 Lyttle, Thomas. "Timothy Leary and Artificial Intelligence: SKIPI." Critique, no. 19/20 (Fall/ Winter):268-74. Discussion of Leary's "Super Knowledge Information Processing Intelligence" computer program, which will enable users to gain novel insights into their personality development.

J459 Mahaney, Timothy. "Psychedelic Pioneers: The Roles of Aldous Huxley and Timothy Leary as Mentors for the Counterculture." M.A. thesis, Department of History, Auburn University. June.

\section{6}

J460 Knauer, G. "Timothy Leary and Futique, Inc." Futurist (Mar.-Apr.):34. About the software company formed by Leary.

J461 Guren, Clifford. "Timothy Leary's Looking Glass." PC World (Oct.): 232-35. Lengthy review of Mind Mirror (A26). "For Leary, personal computers are a natural new frontier, a logical evolution from his explorations of consciousness via hallucinogens."

J462 "The Guru." TV Guide (Dec.). Announcing the casting of Leary in the role of "Guru" in "Showtime's upcoming private-eye series, Hard Knocks."

J463 Lee, Martin A., and Bruce Schlain. Acid Dreams: The CIA, LSD, and the Sixties Rebellion. (New York: Grove Press), pp. 73-89, 96-117, 238-40, 259-76 passim. Historical study includes lengthy accounts of Leary's prominent role in these events. 


\section{K.}

\section{Legal Briefs and Documents Pertaining to Timothy Leary}

\section{8}

K1 No. 23570. In the U. S. Court of Appeals for the Fifth Circuit. Timothy F. Leary, Appellant, vs. United States, Appellee. Brief for Appellant. xviii, 129 pp. Blue wrappers. Petition for Rehearing. 7 pp. White wrappers. Reply Brief for Appellant. iv, 22, 13 pp. White wrappers.

Prepared by Joel Jay Finer, counsel for appellant, Austin, Tex. Leary appealed his conviction for transporting half an ounce of marijuana across the U.S. border from Mex. on Dec. 22, 1965, for which he was sentenced by Judge Ben Connally to ten years in prison. His appeal was largely based on the religious use of marijuana.

K2 Supreme Court of the United States. October Term, 1968. No. 65. Timothy F. Leary, Petitioner, v. United States of America, Respondent. On Writ of Certiorari to the U.S. Court of Appeals for the Fifth Circuit. Motion of National Student Association for Leave to File a Brief Amicus Curiae. iv, 74 pp. Light green wrappers.

Prepared by Joseph S. Oteri, attorney for National Student Association, Amicus Curiae; Harvey A. Silverglate, counsel, and Crane, Inker and Oteri, counsel; and written by O. Michael Risinger and Bob Ashford. This was the key brief that resulted in the Supreme Court decision to overturn the Appeal and lower courts' ruling against Leary, based on the unconstitutionality of laws, concerning importation and transportation of illegal substances, that violated his privilege against self-incrimination. Leary, however, was soon reindicted on a technicality and resentenced to ten years in prison.

K3 State of New York, County Court: Dutchess County. The People of the State of New York against William Haines, The Hitchcock Cattle 
Corporation, Arthur J. Kleps and Timothy Leary. Indictment No. 19/68. The People of the State of New York against John Leary. Indictment No. 20/68.

Memorandum in Support of Motion to Suppress; Notice of Motion for Discovery and Inspection; Notice of Motion for a Bill of Particulars; Memorandum of Law re: Severance and Separate Trials; Memorandum in Support of defendants Timothy and John Leary's Motion to Suppress Evidence; Demurrer.

Legals briefs prepared by Michael Standard of Rabinowitz, Boudin and Standard, attorneys for defendant Timothy Leary. Charges against Leary and the others included possession of cannabis and LSD, following a raid by the Dutchess County Sheriff's Department on Apr. 17, 1966. These charges against Leary stood for about ten years but were eventually dropped.

\section{0}

K4 Dept. no. 17. Case no. C-21237. In the Superior Court of the State of California in and for the County of Orange. The People of California vs. Timothy Francis Leary, Defendant. This certifies that on the 16th day of March, 1970, judgment of conviction of the above-named defendant was entered. . . . He was convicted by Jury on his plea of Not Guilty ... of the crime of Felony, to-wit: Possession of Marijuana . . . in violation of Section 11530 of the Health and Safety Code of the State of California. 2 pp.

C-21237. People vs. Leary, Timothy Francis; Leary, Rosemary; and Leary, John Busch. Hearing re: Probation and Pronouncement of Judgment. 38 pages containing exhibits A, B, C and D1-16..

Orange County Probation Department. Pre-Sentencing Report. 22 pp. Mar. 11.

Abstract of Judgment and Hearing re: Probation and Pronouncement of Judgment, with Pre-Sentencing Report including quotation from Leary and biographical data. Leary was found guilty of possessing two half-smoked marijuana cigarettes on Dec. 24, 1968 and sentenced to one to ten years imprisonment in Calif. state prison. Bail was denied, largely on the basis of Leary's testimony in court, charges against him in the press, certain of his associations, and his own writings, all of which comprise the exhibits. Leary was represented by attorney George Chula. The judge was Byron K. McMillan.

K5 United States District Court for the Central District of California. Timothy Leary, Petitioner, v. Harold V. Field, Superintendent of 
California Men's Colony, West Facility, Los Padres, California, Respondent. Petition for Writ of Habeas Corpus Setting Bail Pending Appeal. 5 pp., with attached 48 pp. of exhibits. Memorandum of Points and Authorities in Support of Petition for Writ of Habeas Corpus Setting Bail Pending Appeal. 46 pp.

Writ of Habeas Corpus prepared by Leary's attorneys Michael Kennedy and Joseph Rhine to grant bail, on the basis that it was frivolous of the judge to deny bail in this case, was denied.

In the Court of Appeal of the State of California, Fourth Appellate District, Division Two. The People of the United States, Plaintiff and Respondent, vs. Timothy Francis Leary, Defendant and Appellant. 4 Crim. 4197. Appellant's Brief. Appeal from the Superior Court of Orange County, Honorable Byron McMillan, Judge. xiv, 129 pp. Blue wrappers.

Appeal brief prepared by Michael Kennedy and Joseph Rhine, attorneys for appellant. The brief challenged the validity of the search and seizure, as well as the heavy sentence for a minuscule amount $(0.01$ gram) of marijuana. When the appeal proved unsuccessful, Leary decided to escape from prison.

Before the grand jury of the County of San Luis Obispo, State of California. The People of the State of California, Plaintiff, vs. Timothy Francis Leary, Defendant. Proceedings Upon Indictment. San Luis Obispo, Calif., Tuesday, Dec. 8, 1970.

Transcript of the Testimony of Witnesses and the Proceedings of the Grand Jury investigation of Leary's prison escape on Sept. 12, 1970. 47 pp.

The grand jury indictment of Leary for his prison escape of Sept. 12, 1970.

\section{1}

K6 An den Schweizerischen Bundesrat, Bundeshaus, 3000 Bern. In Sachen: Dr. Timothy Francis Leary, zur Zeit in Haft im Gefangnis Bois-Mermet in Lausanne.

Three briefs dated Bern, July 16 (3 pp.), July 20 (11 pp.) and Aug. 4, 1971 (12 pp.), written by Leary's attorney H. Mastronardi, petitioning Swiss judicial authorities to release Leary from prison in Lausanne.

The petition proved successful; Leary was released from prison shortly after the last brief was filed and was granted temporary asylum. 
An den Schweizerischen Bundesrat, Bundeshaus, 3000 Bern. In Sachen: Dr. Timothy Francis Leary, geb. 22.10.1920, amerikanischer Staatsangehoriger, z.Zt. in 1884 Villars-sur-Ollon. 20 pp. Oct. 18, 1971. Charge Einsprachebegrundung fur Herrn. Dr. Timothy Leary . . . vertraten durch den unterzeicheneten Anwalt, Sinsprecher betreffend das von den Vereinigten Staaten von Amerika gestellte Auslieferungsgesuch an die Bldg. Polizeiabteilung. 64 pp. Oct. 18, 1971.

Arguments by attorney $\mathrm{H}$. Mastronardi to the Swiss judicial authorities against the extradition of Leary to the United States to face charges of felony convictions for marijuana offenses and escape from prison, based on the theory that Leary was a political prisoner, and the offenses for which he was charged did not demand such excessive prison sentences.

Die Polizeiabteilung des Eidgenossischen Justiz- und Polizeidepartements hat in der Asyl- und Auslieferungsangelegenheit der amerikanischen Staatsangehorigen Timothy Leary . . . und dessen Ehefrau Rosemary Leary . . . Villars-sur-Ollon . . . Bern, Dec. 29, 1971. 10 pp.

Official decision of the Swiss government denying extradition of Leary to the United States to face charges there, allowing him to remain in Switzerland.

\section{3}

K7 In the Superior Court of the State. of California in and for the County of San Luis Obispo. People of the State of California, Plaintiff, vs. Timothy Francis Leary, Defendant. No. 7097.

Affadavit of Prejudice; Motion to Dismiss and to Set Aside Custody for Want of In Personam Jurisdiction; Petition for Writ of Habeas Corpus; Motion for Defendant to Specially Appear as Co-Counsel in All Matters Challenging In Personal Jurisdiction. Each of the foregoing dated Feb. 13, 1973.

Order Denying Petition. Dated Feb. 19, 1973.

Notice of Motion to Vacate Order and Memorandum of Points and Authorities in Support Thereof. Dated Mar. 2, 1973.

Testimony and Cross-Examination of the Defendant in the trial of Timothy Leary for escape from prison in 1970 (approximately $100 \mathrm{pp}$.). Trial Pleadings (46 pp.). Order of Proof (2 pp.).

Leary was represented at his prison escape trial by attorney Bruce $M$. Margolin of Margolin, Somers, Kallen and Tremblatt. The trial judge 
was Honorable Richard F. Harris. In the course of his lengthy testimony, Leary described his state of mind while in prison, with reference to his previous experimentation with psychedelic drugs and the "flashback" syndrome, into which he integrated the theories described in Neurologic (A13), a monograph he was writing at the time, published a few months after the trial. The trial lasted from the last week of Mar. through the first week of Apr. Leary was found guilty of escape and sentenced to six months to five additional years in prison for the offense.

K8 The Court of Appeal of the State of California, Second Appellate District, Division One. The People of the State of California. Plaintiff-Respondent, v. Timothy Francis Leary, Defendant-Appellant. Crim. No. 23769. Appellant's Opening Brief, Aug. 13, 1973. vi, 62 pp. Blue wrappers. Appellant's Closing Brief, Feb. 19, 1974. vii, 75, 29 (appendix) pp.

The appeal of the verdict against Leary in the prison escape trial was handled by attorneys Melvin M. Belli, Vasilios B. Choulos and Kent A. Russell of Belli, Ashe, Ellison and Choulos. The appeal as expressed in the Appellant's Opening Brief was grounded in the belief that "the trial court did not have jurisdiction to try him, because he was abducted in Afghanistan, by agents of the United States . . . in violation of international law, treaties, and the Fourth Amendment. . . ." The Appellate Court affirmed the lower court judgment against Leary on the ground that "abduction from Foreign country presents no issue." This appeal was reported in full in The Los Angeles Daily Journal Appellate Report, Tuesday, Aug. 13, 1974, pp. 59-63. The appeal as expressed in the Appellant's Closing Brief (Reply Brief) was widened to include evidence from Leary's professional career, particularly during the 1960s, that LSD research was valid and that the defendant made significant contributions in this field and should not be regarded as responsible for a "drug epidemic." The Reply Brief was prepared by Stuart A. Shaw of the Belli firm, and published in a variant form: Terra I. The People vs. Timothy Francis Leary, B-26358. x, 59, 45 (appendix) pp., followed by a foldout table. Yellow wrappers, text and photos printed in black. (Variant cover: dark yellow, semi-glossy wrappers, text printed in black, photos printed in silver.) San Francisco: Imprinting Press (for Joanna Leary), Mar. 10, 1974. A small number of copies were printed in this format for general distribution. This latest appeal was also turned down by the appellate court, forcing Leary to privately bargain with Federal authorities in order to secure his release for what now amounted to as much as thirty years in prison on combined federal and state (Calif. and N.Y.) charges. 


\section{4}

K9 U.S. Department of Justice and Federal Bureau of Investigation, Chicago Office. Investigation of Passport Fraud-Conspiracy. 279 pp. Report dated Aug. 16, 1974.

Interrogation of Leary by federal authorities on his 1970 prison escape. News of his willingness to talk resulted in a cause celebre in the political wing of the counterculture, but did not lead to any indictments of those involved in his escape. He was eventually granted parole and released from custody in Apr. 1976 after serving more than four years in prison and six years combined prison-and-exile for possession of a total amount of marijuana of less than one ounce. 


\section{L.}

\section{Miscellanea, including Posters, Fliers, Slogan Buttons and Bumper Stickers}

\section{4}

L1 "An Analysis of the Comprehension Subtest of the Wechsler Scale Form B; with Standards for Scoring." By D. Ramsdell and Timothy Leary. Butler, Penn.: Deshom General Hospital. Printed psychological diagnostic test, formulated and printed while Leary was performing diagnostic screening, interviewing and psychological research in the U.S. Army Medical Corps, 1944-1945. This and the following two items (L2 and L3) are cited as "unpublished manuscripts" in the bibliography to Leary's Master's thesis (AA1), but according to the author they were printed for testing. Not seen.

L2 "The Clinical Use of the Vocabulary Test." By D. Ramsdell and Timothy Leary. Butler, Penn. Deshom General Hospital. Printed psychological diagnostic text (see L1). Not seen.

L3 'Comparison of Certain Rorshach 'Signs' and Qualitative Performance on the Maze Subtest of the Wechsler Scale Form B." By D. Ramsdell and Timothy Leary. Butler, Penn. Deshom General Hospital. Printed psychological diagnostic test (see L1). Not seen.

\section{0}

L4 Starr King School for the Ministry (Berkeley, Calif.). On p. 4 of the school catalog, Leary is listed as the staff psychological consultant and the seminar leader in group counseling. His academic and professional credentials are cited. 
L5 Alpert, Richard, et al. "A Program of Research with Consciousness-Altering Substances." Cambridge, Mass. Mimeographed report produced by the Dept. of Psychology and Social Relations, Harvard University. Not seen; cited in checklist of Leary's publications, c. 1962, and in Wasson, "Hallucinogenic Mushrooms . . Psilocybin" (1963), no. 250.

L5a "Memorandum on Current Psilocybin Projects." Center for Research in Personality, Harvard University. Fall, 1961. Not seen. Cited in Wasson, "Hallucinogenic Mushrooms . . Psilocybin" (1963), no. 251.

L6 Litwin, George, Ralph Metzner and Gunther Weil. "Some Problems Encountered in Working on the Psilocybin Research Project." Cambridge, Mass. Mimeographed report produced by the Department of Psychology and Social Relations, Harvard University. Not seen; cited in checklist of Leary's publications, c. 1962.

\section{2}

L7 "The Mexico Research Center." Two-sheet application form. Boston. Application for residence at Freedom Center, Mex. for the summer of 1962, with brief description of the Harvard Psilocybin Project members' 1961 stay in Zihuatenejo.

\section{3}

L8 "Present Program of IFIF." Apr. Two-page typescript outlining fourteen areas of activity, including prisoner rehabilitation project, experimental community living, psychedelic research projects and publications. Boston.

L9 "Selected Reading List on Consciousness Expansion." Four-page typescript produced by the Castalia Foundation, Millbrook, N.Y.

\section{5}

L10 "Psychedelic Sessions. Timothy Leary and Ralph Metzner. Fall and Winter 1965-66. In New York, Boston, Philadelphia, Pittsburgh, Cleveland, Cincinnati, Detroit, Chicago." Leaflet, 4 pp. Announce- 
ment of "a series of group sessions . . . to produce psychedelic or ecstatic experience without using drugs." Background, methods, tour program, advertisement for books, etc.

L11 “Castalia Foundation Experiential Workshops." Leaflet, 4 pp. Cover design by Alan Atwell. States background, staff, program, location, etc. Printed in red. Millbrook, N.Y.

L12 "The Castalia Foundation for Psychedelic Research Presents Timothy Leary, Ph.D. and Richard Alpert, Ph.D. on How to Use Your Head: a Dialogue on LSD and Consciousness Expansion." Town Hall, N. Y., Nov. 29. Poster, 26 x 20 in. Variant poster for event, different text, 14 x 11 in.

\section{6}

L13 Di Prima, Diane. Printed letter written on letterhead of Timothy Leary Defense Fund for purpose of mass-mailing, fund-raising appeal. Letter signed by di Prima and Allen Ginsberg (but written entirely by di Prima), dated Apr.9.

L14 Timothy Leary Defense Fund. "Dr. Leary's Case Concerns You. Why?" Broadside, 20 x 81/2 in. New York, N.Y., May. Information about Leary's arrests at Millbrook, N.Y. and Laredo, Texas, 1965-66, with a lengthy list of cultural figures who supported him as a victim of unjust marijuana laws.

L15 Timothy Leary Defense Fund. "The Responsible Community is Shocked at the Harsh Sentencing of Psychologist Dr. Timothy Leary." Broadside, $15 \times 13^{1 / 2}$ in. New York, N.Y., May. A variant form of the preceding item, listing Leary's " 52 contributions to the scientific and religious literature."

L16 Timothy Leary Defense Fund. Leaflet printed in blue, folded twice. Buddhist device on title leaf. New York, N.Y., May. Contains essentially the same information given in L14 and L15.

L17 The LSD Conference, June 13-18. Eight-page foldout brochure for the conference held at Berkeley, Calif. Leary's talk was entitled "The Molecular Revolution.” See L26.

L18 League for Spiritual Discovery. Five-page mimeographed statement, setting forth purposes, methods, administrative and legal structure of the organization. Probably written in part by Leary.

L19 "League for Spiritual Discovery Fact Sheet." Four-page, purple-ink, mimeographed press release, dated New York City, Sept. 19. "Dr. 
Timothy Leary announced today the formation of a new religion, based on the sacramental use of psychedelic plants and drugs."

L20 "League for Spiritual Discovery: Psychedelic Religious Celebrations." Printed in green ink on both sides of one sheet. Announcing weekly "psychedelic worship ceremonies" at the Village Theater, New York City, beginning Sept. 20.

L21 "In Person Dr. Timothy Leary. A Series of Three Psychedelic Celebrations. \#1 The Death of the Mind. \#2 Reincarnation of Jesus Christ. \#3 Illumination of the Buddha." Village Theatre, New York City, Sept. Flier, 13 x 8 in.

L22 “Turn On, Tune In, Drop Out." Slogan button, c. 1966-1967.

L22a "I'm Weary of Leary." Slogan button, c. 1966-1967.

L22b "Be Leary of LSD." Slogan button, c. 1966-1967.

L23 “League for Spiritual Discovery." Slogan button, c. 1966-1967.

L24 Castalia Foundation Millbrook Summer School. Eight-page brochure printed in green and black announcing "psychedelic training courses" and describing program, staff, etc. Probably written in part by Leary.

\section{7}

L25 Anderson, Chester. “Uncle Tim'\$ Children." Four mimeographed pp., stapled, dated Apr. 16, printed and distributed by the Communication Company, San Francisco. Protest against Leary and hippie "capitalists."

L26 Lamb, R. E. "Impressions of the LSD Conference (June 13-18, 1966), Berkeley, California." Western Washington State College: Department of Philosophy, Jan. Forty-one leaf mimeographed text of notes taken at the conference, including those on Leary's talk, "The Molecular Revolution," pp. 15-17. The full text of the talk appeared in The Politics of Ecstasy (A8) one year later. There was no separate printing of the talk.

L27 The Love Ins. A feature film starring Susan Oliver and James MacArthur, with Richard Todd as a character based in part upon Leary. Hollywood.

L28 "I Am a Human Be-In." Black and white photo-portrait of Leary by John W. Doss, M.D.; text printed in lower left. Four Winds Foundation. Poster, $28 \times 201 / 2$ in. 


\section{MALl ORDERS ONLY!}

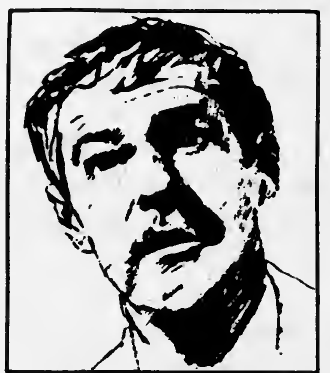

IN PERSON

\section{DR. TIMOTHY LEARY}

\section{A SERIES OF THREE}

PSYCHEDELIC CELEBRATIONS

Re-enactments of the world's great religious myths using psychedelic methods: sensory meditation, symbol-overload, media-mix, molecular and cellular phrasing, pantomime, dance, sound-light and lecturesermon-gospel.

PSYCHEDELIC ART BY JACKIE CASSON \& RUDI STERN (As Featured in the September 9th issue of LIFE Magazine.)

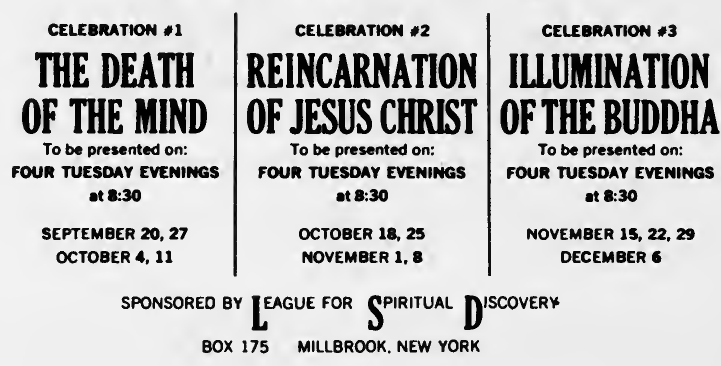

L21: Flier for Leary and Metzner's 1966 public "psychedelic celebrations."

L29 Photo of Leary by Fred W. McDarrah, right profile, identical to that used on dust-jacket of High Priest (A7). "Authorized by the League for Spiritual Discovery." New York: "Personality Poster," 291/2 x 41 in. Reproduced on stiff postcard, 5 x 8 in., c. 1967; on slogan button, c. 1967; on 3 of spades in Celebrity Playing Card miniature deck, 21/4 X $15 / 8$ in., sold in novelty shops c. 1970 .

\section{8}

L30 "Uncle Tim's Fly-Hi Glider: An Educational Do-It-Yourself Kit for All Ages." Washington Free Press (Feb. 20). Reprinted from the Chicago Seed. Cutout model airplane in image of Leary flying. 
L31 Barney Wilen and His Amazing Free Rock Band. Dear Prof. Leary. MPS 15191. Germany: Gema. "Dear Prof. Leary" (side 1, cut 2) written by Joachim Kuhn.

L32 The Who. "The Seeker." 45 rpm single. Re-released on long-playing record albums, The Who's Greatest Hits and Meaty Beaty Big and Bouncy. Lyrics of this popular song include the following: "I asked Timothy Leary/ But he couldn't help me either."

L33 I Love You, Alice B. Toklas. Feature film produced by Paul Mazursky and Larry Tucker from their original screenplay. Starring Peter Sellers and Leigh Taylor-Young. Hollywood: Warner Brothers-Seven Arts. Selections from The Psychedelic Experience (A4) are read by Taylor-Young to Sellers playing a character having his first LSD trip. Novelization: see J155.

\section{9}

L34 "Tim Leary in a Series of Five Seminars to Benefit the Free University of Berkeley," Feb. 12-22. Poster designed by Nick Story, 13 x 10 in. Printed in red on yellow.

L35 "Give Peace a Chance." Color photo of John Lennon, Yoko Ono, Timothy and Rosemary Leary and Tom Smothers at Montreal "Bed-In" playing guitars and singing Lennon song "Give Peace a Chance." Poster by Random Hazard, 21 x 25 in. Hollywood: Frank Kay Distributors. See F7 and G14.

L36 "Timothy Leary/ Heads for Peace." Window sticker printed in red, white and blue. Produced for the Leary for Governor campaign.

L37 "Tim Leary for Governor." Multicolored bumper sticker.

L38 "Timothy Leary for Governor of California. Come Together . . . Join the Party," with photograph of Leary by Fred W. McDarrah (same as that used on dust jacket of High Priest). Black-light reflective color poster, $281 / 2$ x $201 / 2$ in. Artist: Joe Roberts, Jr.

\section{0}

L39 "Om Orgy: A Holding Together for the Timothy Leary Family," held at the Family Dog on the Great Highway, San Francisco, Apr. 16. Flier printed in purple and black on white, $16 \times 8$ in. Artist: Barry Thomas.

L40 Holding Together Defense Fund. Apr. Leaflet, 4 pp., printed in brown, consisting of photos, news clips, quotations from Leary, and comments concerning his imprisonment. $24 \times 11$ in. Berkeley. 


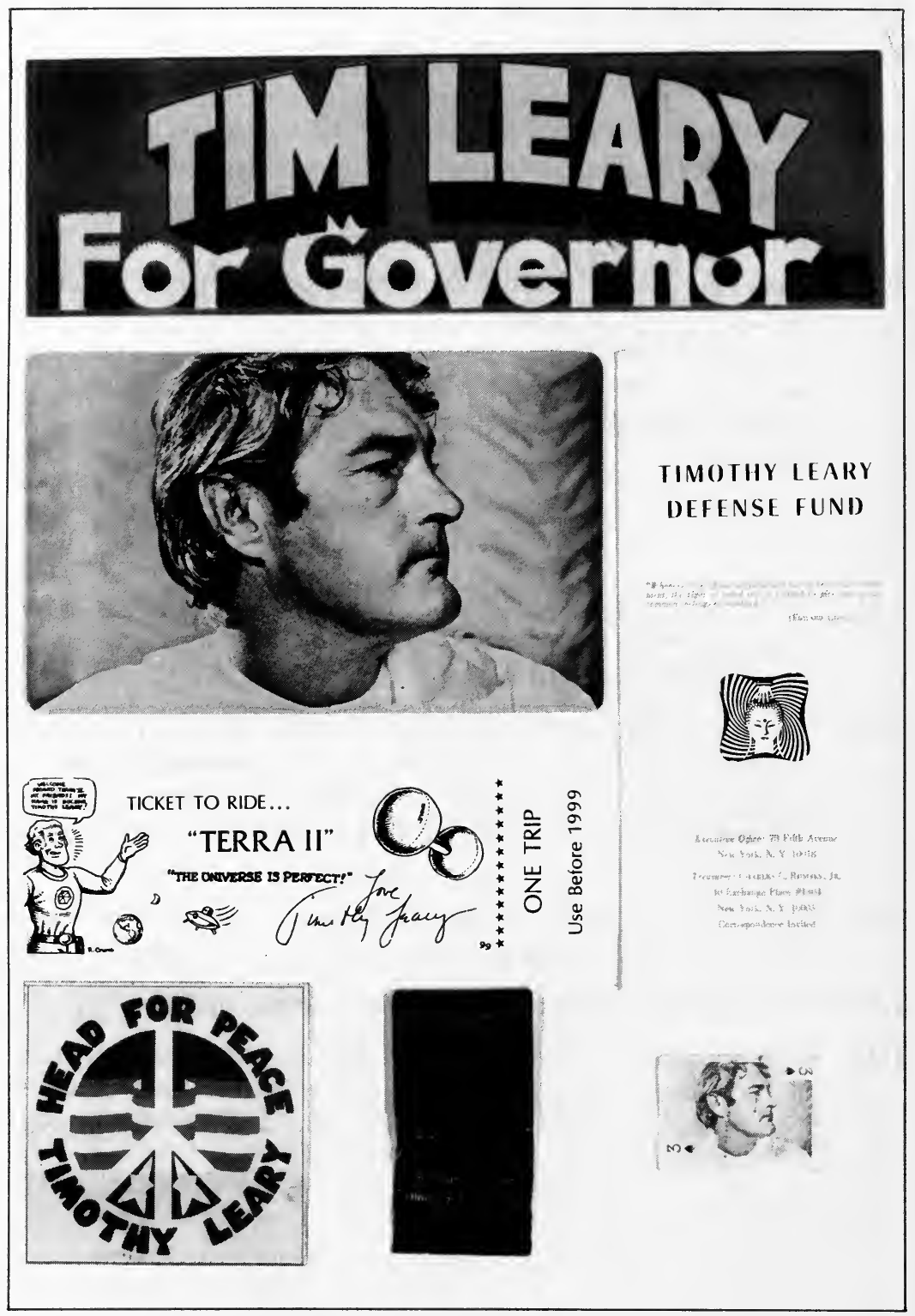

Some Leary ephemera (from left to right): bumper sticker (L37), postcard (L29), promotional ticket (L56), brochure (L16), window sticker (L36), matchbook (L63), and playing card (L29). Courtesy Fitz Hugh Ludlow Memorial Library. 
L41 Holding Together Defense Fund. Flier of Leary standing atop Chinese hexagram for "holding together" with information on his case printed on verso. $14 \frac{1}{2} \times 8 \frac{1}{2}$ in. Artist: Barry Thomas.

L42 "Timothy Leary Kidnapped by Government Officials. \$100,000 Ransom Needed. Holding Together a Freedom Fund." Poster printed in black on ocher, $27 \times 18$ in. Variant: same text but different design, incorporating image of Leary in center, printed in black on green. $26 \mathrm{x}$ 20 in. Artist: Bill Ogden.

L43 Broyles, Doug. "Prometheus Bound (This Time Around)," adapted from Aeschylus's play and produced in Berkeley, in Aug. to benefit Holding Together, the Leary defense fund. Mimeographed acting script, $18 \mathrm{pp}$. Broyles played the role of Prometheus, updated to suggest the imprisoned Leary.

L44 "Prometheus Bound (This Time Around)," produced in Berkeley, Aug. Poster announcing play printed in red and orange on white. $2 \times 1 \mathrm{ft}$. Artist: Barry Thomas.

L45 "Manifesto." Text of Leary's prison escape letter, dated Sept. 1970 (C70, etc.) and black and white photo of young people holding rifles aloft. Poster, $22 \frac{1}{2} \times 17$ in. Photographer: Jack Weir. Printed by the Borborigmus Press, Berkeley.

L46 Publicity poster depicting Leary and other 1960s political celebrities (Eldridge Cleaver, Dr. Benjamin Spock, Abbie Hoffman, Jerry Rubin etc.) in the guise of Christ and the apostles at the Last Supper, used for promotion of the College Notes \& Texts edition of High Priest (A7b and $\mathrm{A} 7 \mathrm{c}$ ). 2 x $3 \mathrm{ft}$. Artist: Frank Adams.

L47 Craddock, William J. Be Not Content. Garden City, N.Y.: Doubleday, p. [7]. "Turn On, Tune In, Drop Out" used as an epigram for this novel of the Haight-Ashbury in the mid-1960s.

\section{1}

L48 Christmas card depicting Madonna with Child surrounded by halo of words, "You Can Be Anyone This Time Around," from title of Leary's record album. Artist: Trina Robbins. San Francisco: Hotcha! Thing Co.

\section{3}

L49 "Comet Kohoutek Celebration/ Starseed Benefit for Immediate Release of Dr. Timothy Leary," held in San Francisco, Dec. 28. Flier with image of Jimi Hendrix and UFO printed in purple on white. $16 \times 21$ in. 


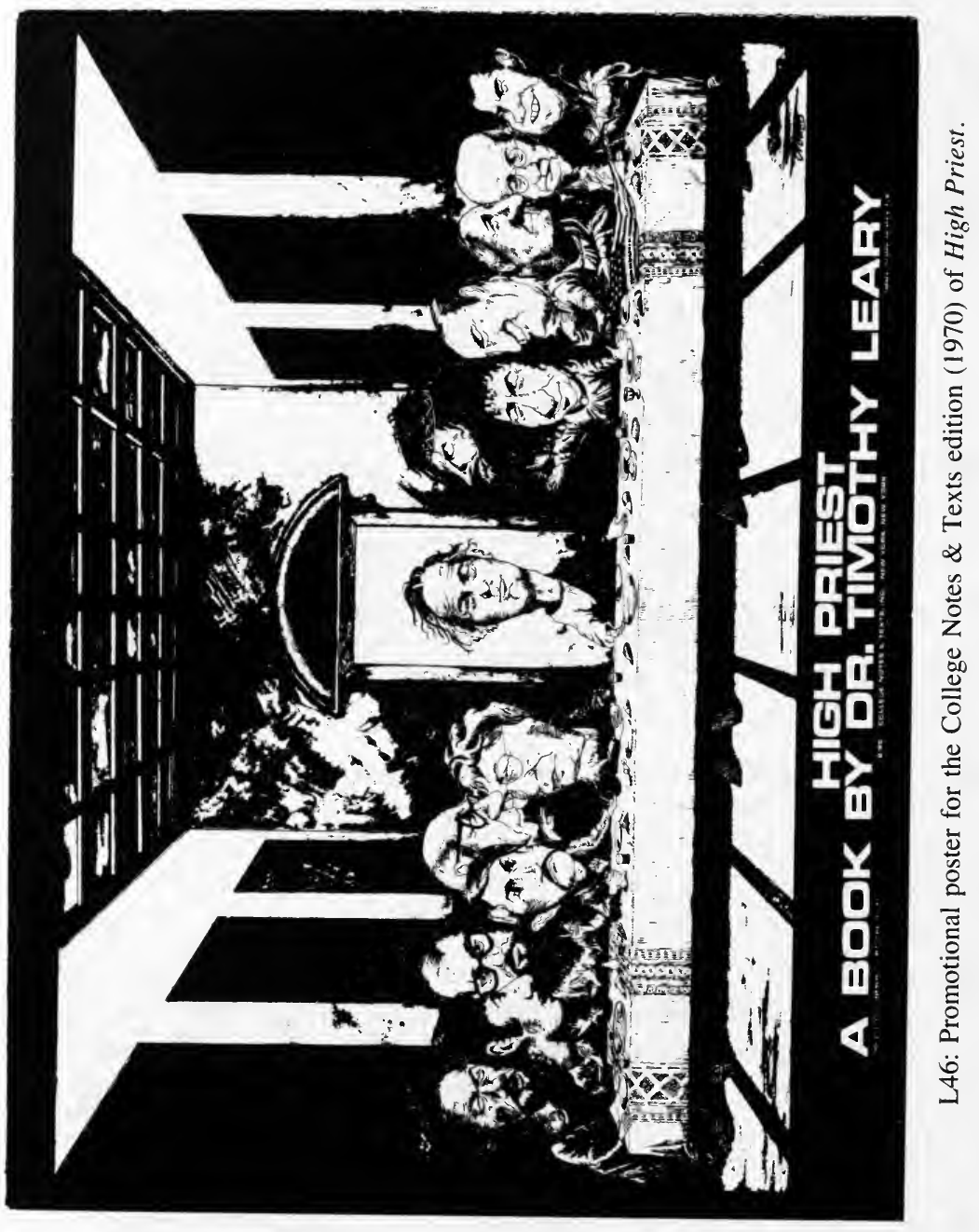


L50 "Free Timothy Leary." Bumper sticker printed in black on white with orange sun.

L51 Spiegelman, Art, and Bob Schneider. Whole Grains: A Book of Quotations. (New York: Douglas/ Links). Eight quotations from Leary's statements and writings are scattered through this anthology.

\section{4}

L52 Horowitz, Michael. ARCANA (Archival Reality Conference Advocating the Neutrality of Archivists) statement, 1 p., distributed at press conference at St. Francis Hotel, San Francisco, Aug. 6. Horowitz, subpoenaed by a grand jury in the Leary escape investigation, protested the seizure of the Leary archives by the FBI and advocated the political neutrality of archivists.

L53 "Shine Like Stars, Energize, Electrify Every Word And Deed." Quotation from Leary's Starseed (A15) on black and white collage poster, 19 x 16 in. Artist: Martin Carey.

L54 Russell, Kent. Dr. Freedom. 45 rpm. San Francisco: Golden State Recorders. A song about Leary composed by one of his attorneys.

\section{5}

L55 DNA Society. Form letter, dated San Francisco, Jan. 31. One-page letter expressing concern about the "disappearance" of Leary while in federal custody. Signed by Michael Horowitz, John James, Robert Newport, Carl Spann, Carol Tickner and Robert Anton Wilson.

L56 "Ticket to Ride. . . ." Promotional bookmark inserted in some copies of Terra II (A16). Printed in black on blue, with a drawing of Leary and orbiting space colony by R. Crumb (reproduced from his comic book, Dirty Laundry, J319), with the following text: TICKET TO RIDE . . . I "TERRA II"/ "THE UNIVERSE IS PERFECT"/ (in author's facsimile handwriting:) Love/ Timothy Leary. Text in balloon above Leary; on stub: ONE TRIP/ Use Before 1999. Approximately 500 bookmark-tickets were printed and distributed in February 1975 at the "Wake Up Celebration" (see L57) by the designers Michael Horowitz and Dana Reemes.

L57 "Wake Up Celebration" with Ken Kesey, Paul Krassner, Wavy Gravy, Robert Anton Wilson, Carol Tickner and Michael Horowitz, held at University of Calif., Berkeley, Feb. 8. Flier, 11 x 81/2 in. Rally was held to protest the disappearance of Leary while in federal custody. 
L58 "No More Secrets." Slogan button produced by Joanna Leary in connection with Leary talking to federal authorities.

\section{6}

L59 Rukeyser, Muriel. Mimeographed two-page letter on American P.E.N. Center letterhead, urging U.S. authorities tò release Leary from prison, dated New York, N.Y., Apr. 14.

L60 Hildebrand, Tim. Rotwang Or the Delerious Precision of Dreams. Berkeley: Blue Wind Press. P. 6: "Excerpts from this book were also published in What Does WoMan Want? by Timothy Leary."

1977

L61 Webb, Jimmy. El Mirage. Long-playing record album. Atlantic SD 18218. ATCO. Dedicated to Ramblin' Jack Elliott, Kurt Vonnegut and Timothy Leary.

1980

L62 "Intelligence Is the Ultimate Aphrodisiac/ Read The Intelligence Agents By Timothy Leary. Peace Press [followed by address]." Bumper sticker. Later variants have an added phone number, price of book added and distributor's name, or have reversed colors. Los Angeles.

L63 "Intelligence Is the Ultimate Aphrodisiac." Slogan imprinted in gold on dark blue matchbook.

\section{1}

L64 "SMI LE." Slogan imprinted on T-shirt. Chico, Calif. Slogan coined by Leary as acronym for Space Migration, Intelligence Squared, Life Extension.

\section{3}

L65 Chamberlain, Elwyn. Gates of Fire. 2nd ed., revised. Berkeley: North Atlantic Books. Contains back cover blurb by Leary: “. . . one of the ten best books ever written by an American . . . surely the best book ever written about India." 
L66 Pop-O-Pies. The White L.P. San Francisco: 415 Records. "Timothy Leary Lives," song composed by Joe Callahan, is the fourth cut.

\section{4}

L67 "Leary, Timothy." Who's Who in America. (Chicago: Marquis Who's Who). 43rd ed. Leary's first appearance in this reference work.

\section{5}

L68 "Timothy Leary Workshops: Headware for the Computer Age." Masonic Temple, Los Angeles, Apr. 28-May 19. Printed flier, accompanied by by four mimeographed sheets describing the workshops and staff of Futique Inc. High Tech University.

\section{6}

L69 "Turn On, Tune In, Boot Up." Slogan button produced for and distributed at Leary's Futique computer workshops in Los Angeles. 


\section{Title Index to Timothy Leary's Works}

"About Franz Gertsch," 152, 209

"Access Codes and Carnival Blasts," 206

"Acid Return," 202

"After the Sober, Serious, Safe and Sane '70s, Let Us Welcome the Return of LSD," 226

"Afterword" (In Search of Timothy Leary), 155

"America's Team," 199

American Culture: 1945-1985, 220

"American Education as an Addictive Process and Its Cure," 43, 112

"Americans and Mushrooms in a Naturalistic Environment," 107

"And the Twain Shall Never Meet," 197

"Another Session with Timothy Leary," 201

“Artificial Intelligence: Hesse's Prophetic “Glass Bead Game,'” 200, 212

At Folsom Prison, 222

"Big Boom Theory, The," 200

"Book for Oscar, A," 225

"Brainwashing: How To Fold, Spindle, and Mutilate the Human Mind in Five Easy Steps," 71, 195

"Bread of the Gods," 191

"Change Program for Adult Offenders Using Psilocybin, A," 115

"Changes," 141, 188, 210, 212, 215

"Changes in Psychoneurotic Patients With and Without Psychotherapy," 93, 132, 182

Changing My Mind, Among Others, 77
"Cheerleader for Change: The Timothy Leary Interview," 206

"Chemical Warfare-The Alcoholics vs. the Psychedelics," 43

"Child's Primer of Neurologics, The," 226

"Classification of Interpersonal

Behavior," 171

Clinical Use of Wechsler, 84

"Come Together, Join the Party," 151, 202

"Comments from Tim Leary on Ken Kesey's Letter," 193

"Communication with the Higher Intelligence: A Review of Albert Bester," 196

"Communist Thought on the Negro," 85,180

Confessions of a Hope Fiend, 56, 212, 213

"Cosmic Courier, The," 190

"Cosmic Wink of the Third Eye, A," 196

Curse of the Oval Room, The, 64, 71

"Day I Was Busted By G. Gordon Liddy, The," 194

Day with Timothy Leary, A, 220

"Deal for Real," 146, 175, 191, 209

"Declaration of Evolution," 43, 44, 190

"Diagnosis and Treatment of Psychotherapy Research," 97, 225

"Diagnosis of Behavior and the Diagnosis of Experience, The," 147

"Dimensions and A Measure of the Process of Psychotherapy, The," 95, 120

"DMT Report," 107 
"Dr. Timothy Leary" (Splash), 207

"Dr. Timothy Leary: Blowing the Conditioned Mind," 203

"Dr. Timothy Leary, from the Psychedelic Sixties to the Electronic Eighties," 207

"Does Timothy Leary Eat Mushroom Pie?," 202

"Drop Out or Cop Out," 43

"Drug Cult Guru Still Heading for Outer Space," 206

"Drugs and Freedom-an Academic Question," 183

"Drugs, Set and Suggestibility," 103

"Eagle Brief, The," 46

"Ecstasy Attacked-Ecstasy Defended." See "Some Cool Thoughts on a Hot Issue"

"Effects of Consciousness-Expanding Drugs on Prisoner Rehabilitation, The," 191

"Effects of Test Score Feedback on Creative Performance and of Drugs on Creative Experience, The," 108, 128

"Electronic Sex: Turning on to Your Computer," 199

"Episode and Postscript," 144, 191

"Erotic Brain, The," 200

"Even to Envision Success on This

Scale is a Victory," 199

"Evolution of Computer Literacy, The," 207

"Existential Transaction," 96

Exo-Psychology, 67, 179, 196, 209, 211

"Experiential Typewriter, The," 186

"Extraterrestrial Migration," 226

"Faces," 198, 199

Final Taboo, The, 220

"Fifth Freedom, The-The Right to Get High." See "Politics of Consciousness Expansion, The"

"Five Psychedelic Prayers Adapted from the Tao Te Ching," 186

Flashbacks, 79, 209, 212

"For Allen Ginsberg," 179

Foreword (Alien), 160, 211

"Foreword" (Joyous Cosmology, The), 122,210
"Foreword" (N.Y. City), 163

"Forewords" (Cosmic Trigger), 158

"Freedom Center Incorporated," 110

"From Inner Space to Outer Space,"

71,195

"Future of Sex, The," 198

Futz (a review), 191

Game of Life, The, 74, 211

"Game of Life, The. III: The 21st Century I Ching," 226

"Give Peace a Chance" (record), 215

"Give Peace a Chance" (video tape), 222

"God and Timothy Leary," 201

"God Game, The: How to Win," 202

"God's Secret Agent .0025." See "God's Secret Agent A.O.S.3"

"God's Secret Agent A.O.S.3," 43, 153, 190, 209

"Government Violations and the Non-Violent Hippies," 140, 190

"Great Millbrook Snot Bust, The," 150, 188

"Hands On!," 166

"Hedonic Isolationism," 151, 203

Hedonic Psychology, 225

"Helping the Helpless," 103

"Hermann Hesse: Poet of the Interior Journey," 43, 129, 183

High Orbit, 226

High Priest, 35, 209

"Higher Consciousness and Creativity," 198

"Hochst-Interaktiv Software," 212

"Homage to the Awe-Full Seer," 43, 190

"Hormonal Politics: The Menopausal Left-Right and the Seed Center," 43

"How I'd Make L.A. a Better Place," 207

"How Merry Jerry's Yip Stopped the War," 190

"How to Change Behavior," 99, 121, 125,172

"How to Surf the Crime Wave," 197

"How to Wash Brains." See "Brainwashing"

"Huck and Jim in Their Interpretive Balloon," 182 
"Impolite Interview with Timothy Leary, An," 43, 201, 209

"In and Out of Time," 196

"In Defense of Snake Oil Salesmen." See "Tim Leary on Snake Oil, Liberals, and Amino-Uganda"

"In Search of the True Aphrodisiac," 200, 212

"In the Beginning, Leary Turned on Ginsberg and Saw That It Was Good ...., 190

"Incident of Violence Avoided," 192

"Increasing Intelligence," 196

"Individual in the College Community, The," 43, 112, 174

"Innerview," 204

Intelligence Agents, The 71, 166, 211

"Interpersonal Behavior and Behaviorism," 105, 183

Interpersonal Diagnosis of Personality, 23

"Interpersonal Diagnosis: Some Problems of Methodology and Validation," 92, 126, 182

"Interpersonal Dimension of Personality, The," 87,181

"Interpersonal Dimension of Personality, The: II," 92, 182

"Interview" (Future Life), 205

"Interview" (Surfer), 205

Interview in Vacaville Prison, 218

"Interview, An-Timothy Leary, LSD, and Religion," 43, 201

"Interview mit Timothy Leary," 210

"Interview with Dr. Timothy Leary" (Heads Up), 202

"Interview with Dr. Timothy Leary" (Maclean's), 204

"Interview with Timothy Leary" (LA Star), 204

"Interview with Timothy Leary"

(Sunday Ramparts), 201

Interview with Timothy Leary (video tape), 223

"Introduction" (LSD: The

Consciousness-Expanding Drug), 124

"Introduction" (J. Social Issues), 181

“Jail Notes," 47, 193, 209

"Joys of Pornography, The," 199
“Kekule's Dream Serpent Makes a Good Logo: A Review of Thomas Pynchon," 196

"Languages: Energy Systems Sent and Received," 117, 186

"Last Message of Aldous Huxley, The," 43, 156, 185

"Laughing Leary," 151, 202, 209, 210

"Laughing Religion." See Neo-American Church Catechism and Handbook

"League (for Spiritual Discovery) Fact Sheet," 188

"Leary Dialogues, The," 151

"Leary Live in Sauerland," 166, 220

"Leary Love Rap," 202

"Leary Statement," 194

"Leary Trades Drugs for Space Colonies," 204

"Leary-Lettvin Debate, The," 188, 222

Letter from Algeria, 192

Letter from Switzerland, 193

"Letter from Timothy Leary," 148, 153, 178, 192

"Letter to Allen Ginsberg, A," 192

Letter to Forum members, 193, 218

Letter to the Editor: in Co-Evolution Quarterly, 196; in Horace Mann Monitor, 197; in Los Angeles Herald Examiner, 197; in Los Angeles Times, 197; in Los Angeles Times Calendar, 197; in Newsweek, 195; in New York Times Book Review, 194; in Playboy, 185, 191; in Psychedelic Monographs and Essays, 200; in Psychology Today, 193; in Reporter, 183; in Spit in the Ocean, 194

Letter to the Food \& Drug Administration," 183

Letter to William Buckley (National Review), 195

Life Cycles: 24 Love Songs for Each Stage of Life, 226

Living in Space, 219

"Los Effectos Psychoterapeuticos," 106 L.S.D. (record album), 214

L.S.D.: A Documentary Report (record album), 214

"LSD Is Air," 178

"LSD: Leary Software Development," 207 
“Magical Mystery Trip, The," 43, 190

"Manifesto," 175, 293

"Measurement of the Group Process and the Nature of Therapeutic Improvement in Group Psychotherapy,' 87, 181

"Measuring Verbal Interaction in Freudian and Rogerian Psychotherapy," 108

“Meeting Manson," 71, 195

"Message from Leary," 192

"Methodology for Measuring Personality Changes in Psychotherapy, A," 94, 182

Mind Mirror, 82

"M.I.T. Is T.I.M. Spelled Backwards." See "Interview, An-Timothy Leary, LSD, and Religion"

"Molecular Revolution, The" 43, 289

"Movement into Space: A View from Two Worlds," 204

Multilevel Measurement of Interpersonal Behavior, 21

"Murder of Mary Pinchot Meyer, The," 198

"Mushrooms for Lunch," 156

"My Debt to Deborah Davis," 198

"Neo-American Church Catechism and Handbook, The: a Review," 137, 150,188

"Neue Kathedralen im Weltraum" (interview), 211

"Neuro-Astrology," 196

Neurocomics, 74, 208, 211

Neurologic, 51, 193, 194, 209, 211

"Neurological Politics," See Declaration of Evolution, The

Neurologique. See Neurologic

Neuronaut Returns, The, 220

Neuropolitics, 69, 211

"Neuropolitics: The Meaning of Space Migration," 159, 197

"New Behavior Change Program Using Psilocybin, A," 115, 185

"New Literacy, The: Electronic Language," 169

"No Golden Anniversary for this Ex-Dodger Fan," 199

"Ode to a Pyramid," 197

"On Drugs: Dr. Leary," 207
"On Mind as Aphrodisiac: Interview with Timothy Leary," 206

"On Programming Psychedelic Experiences," 188, 209

"Once and Future Timothy Leary, The," 205

“Onward Christian Soldiers," 200

"Open Lètter to Allen Ginsberg on the Seventh Liberation," 192

"Operation Sex Change," 200

"The Oracle interviews Timothy Leary," 202

"Outlaw Industry, The." See "TV and the Outlaw Industry"

"Pact with Higher Intelligence," 226

"Patterns of Social Interaction and Their Relation to Personality Structure," 86,181

“Perfect Worlds," 199

"Periodic Table of Energy, The," 194

"Persecution of Larry Flynt, The," 199

"Personal Computers/ Personal Freedom," 167

"Phone Call from Jail, A," 204

Pilot Study Research Project, 97

"Playboy Interview: Timothy Leary," 117, 139, 201, 209

"Poems on the Conduct of Life for Barbara and Chuck," 191

"Politics and Ethics of Ecstasy, The," 186

"Politics, Ethics, and Meaning of Marijuana, The," 133, 174

"Politics of Consciousness Expansion, The," 43, 114, 134, 183, 210

Politics of Ecstasy, The, 39, 209, 210 , 211

"Politics of the Nervous System, The," 43,183

"Pornography Is Good; Scornography Is Bad," 226

Power of Imprinting, The, 219

"Prediction," 150, 202

"Prediction of Interpersonal Behavior in

Group Psychotherapy, The," 90, 181

"Predictions," 161

"Preface" (Great Books of Cannabis), 164

"Preface" (Spit in the Ocean), 196

"Prehistoric Origins of DNA," 172

Prelude to Nothing, 19 
"Principles and Practice of Hedonic

Psychology, The," 193

"Problems in Collaboration," 181

"Problems of Expanding

Consciousness," 111

"Program for Training in Creativity," 105

"Programmed Communication During Experience with DMT," 186

"Progress Report: Behavior Change Research Program," 104

"Progress Report: Behavior Change Research Project," 98

"Progress Report: Harvard Rehabilitation Program," 104

"Progress Toward Solving the Problem of Race Relations," 85, 180

Psychedelic Experience, The (book), 25, 210, 212

Psychedelic Experience, The (leaflet), 118

Psychedelic Experience, The (record album), 214

Psychedelic Moment, The, 225

Psychedelic Prayers, 29, 210

Psychedelic Theory, 225

"Psychedelic Utopia," 201

Psychological Effects of High Orbital Migration, The," 226

"Psychological Service and Research," 181

Psychology of Pleasure, The. See Hedonic Psychology

"Q \& A: Timothy Leary," 206

"Q \& A: Timothy Leary: The Case for Intelligent Drug Use," 206

"Quantum Jumps, Your Commodore and You," 200

"Rationale of the Mexican Psychedelic Training Center," 127

"Reactions to Psilocybin Administered in a Supportive Environment," 116, 185

Release, 222

"Religious Experience, The: Its Production and Interpretation," 43, 114, $129,154,185$

"Religious Implications of Consciousness Expanding Drugs," 113, 183, 208
"Results and Implications of the Group Therapy Program," 181

Return Engagement, 223

"Role of Level III (Projective) Data in Prediction, The," 225

"Role of the Free Agent in the Computer Culture, The," 200

"Rolling Stone Interview with Timothy Leary, The," 203

"Science," 162

"Scientist Superstars," 197, 211

"Scripts," 193

"Second Fine Art, The," 186

"Seed Transmission," 176

"Seeds of the Sixties," 71, 195

"Self-Indulgence, Survival, and Space," 197

"Session \#16," 106

"Seven Tongues of God, The." See "Religious Experience, The: Its Production and Interpretation"

Seven Up, 215

"Sexual Revolution 1977-2001, The," 196

"She Comes in Colors," 43, 176

"Sheeeeeee. She is Highest Intelligence," 194

"Smoke It/ Smoke It/ Blow It Up," 192 Social Dimensions of Personality, 86

"Social Implications of the Group Therapy Situation," 181

"SOL Session with Timothy Leary," 43, 202

"Some Cool Thoughts on a Hot Issue," 43, 185

"Some Personal Observations on the Emergence of Third and Fourth Brain Imprints in Adolescent Males," 195

"Some Superficial Thoughts on the Sociology of LSD," 166

Space Migration, 218

Space Psychology, 218

"Speech That Never Was, The," 138

"Sphinx: Das Magazin des Jahrzehnts," 168

"Spooked Trickster, The Whimsical Scientist, and the Flunked Anthropologist, The," 198

Starseed, 58, 71, 194, 209, 210, 212

Start Your Own Religion, 33, 43, 188

"Statement of Purpose of the International Federation for Internal Freedom," 111 
"Statement of Timothy Leary . . . Testifying on Behalf of the Castalia Foundation," 131

"Statement on Speed," 191

Static and Exstatic Dimensions of Consciousness and their Communication, 225

"Technique of Group Psychotherapy, A," 181

Terra II, 62, 194, 209, 211

"Thank God for the Beatles," 142

"Theory and Measurement Methodology of Interpersonal Communication, The," 93, 182

"Theory and Methodology for Measuring Fantasy and Imaginative Expression, A," 95, 182

"They Took Away My Credit Card," 203

"Thinking, Talking and Doing," 96

"3 Billion Years from Amoebas to Howard Cosell," 205

"Tim Leary" (In Magazine), 206

"Tim Leary: or, Bombs for Buddha," 203

"Tim Leary Drops a Line," 195

"Tim Leary: Interview" (Los Angeles Star), 203

"Tim Leary: A Letter and an Interview from Prison," 203

“Tim Leary's Magic Bullet," 198

“Tim Leary's Prediction." See "Prediction"

"Timothy Leary" (Slick), 205

"Timothy Leary" (Wet), 205

"Timothy Leary on Acid and the CIA," 205

Timothy Leary, Appellant v. State of California, Appellee, 46, 192

"Timothy Leary: The Doctor Is In," 206

Timothy Leary: His Version of the World and History, 218

"Timothy Leary Inside Out," 207

"Timothy Leary: Messenger of Evolution," 204

"Timothy Leary-Reflections on Society," 195

Timothy Leary \& Robert Anton Wilson, 219

“Timothy Leary: Space Cadet," 205
"Timothy Leary: Still (SMILE)*ing After All These Years?," 205, 211

"Timothy Leary: This Fine Madman," 203

"Timothy Leary's Melrose Avenue for William Burroughs," 199

"Timothy Leary's New Trip: A Reason Interview," 205

"To Find and Foster the Creative," 98

Tomorrow We Live, 225

"Tree Above, The-the Tree Below," 172

Trial testimony, Chicago, December $19,1969,143,173$

"Tribute to Jackie Cassen, Rudi Stern, A," 118

Turn On, Tune In, Drop Out (record album), 214

Turn On, Tune In, Drop Out (motion picture), 221

"Turn On, Tune In, Drop Out," 177, 186

"Turn On, Tune In, Drop Out (Basic Turn On Methods)," 187

"Turn-on, Tune-in, Take Charge?," 206

"Turning On the World," 173

"TV and the Outlaw Industry," 71

"Two Commandments for the Molecular Age, The," 133

"Unreported Rape of Irving Katz, The," 200

"Use of Psychedelic Drugs in Prisoner Rehabilitation," 186

"Variability Dimension of Personality," 89

"Violence is Killing by Machines at a Distance," 140, 191

"Violent Governments, Nonviolent Hippies," 140

"Wanderers, The," 149

Wanted!!, 44

"We Were Freed by a Great Network of Love," 203

Wegmuller's paintings (critique), 153

"We're Together and We've Probably

Never Been Happier," 203

"We've Lost the War; Legalize All the Drugs," 199 
"What to Do When the Vietcong Drops LSD in Our Water Supply." See "Politics of the Nervous System, The"

What Does WoMan Want?, 65, 211

"What Kind of Party Do You Want?," 191
"XTC: The Drug of the ' 80 s," 200

"You Are a God, Act Like One!," 188, 209, 210

You Can Be Anyone This Time Around, 215 

